ВИЩИЙ НАВЧАЛЬНИЙ ЗАКЛАД «УНІВЕРСИТЕТ ЕКОНОМІКИ ТА ПРАВА «КРОК»

\title{
ЕКОНОМІКА НЕВИЗНАЧЕНОСТІ: ЗМІСТ, ОЦІНЮВАННЯ, РЕГУЛЮВАННЯ
}

Колективна монографія за редакцією Радіонової I. Ф. 


\title{
УДК 330.101
}

E-45

\author{
Рекомендовано до друку Вченою радою \\ Вищзого навчального закладу «Університету економіки та права «КРОК» \\ (протокол №6 від 25.06.2020 p.)
}

\section{Рецензенти:}

Базилевич В. Д. - член-кор. АН України, д.е.н., професор, професор кафедри економічної теорії, макро- та мікроекономіки Київського національного університету імені Тараса Шевченка

Ватаманюк О. 3. - д.е.н., професор, професор кафедри економічної теорії Львівського національного університету імені Івана Франка

E-45 Економіка невизначеності: зміст, оцінювання, регулювання: колективна монографія. Київ : ВНЗ «Університет економіки та права «КРОК». 2021. 287 с.

\section{ISBN 978-966-170-048-1}

Монографію присвячено важливому явищу економічного життя суспільства, актуальність якого суттєво зросла на початку XXI ст. Йдеться про економічну невизначеність. Автори цього дослідження намагалися дати відповіді на питання про зміст та прояви економічної невизначеності, про способи ії оцінювання та регулювання. При цьому зроблено акцент на тих процесах та явищах економічної, соціальної, управлінської сфер, які виявились впливовими щодо посилення або, навпаки, послаблення (обмеження) економічної невизначеності.

Текст цієї монографії може бути корисним для викладачів економічних, управлінських дисциплін та науковців, фахівців різних ринків, студентів та аспірантів.

Автори монографії вдячні всім її читачам i, особливо, тим, хто висловиться щодо змісту роботи та обгрунтованості презентованих у ній ідей.

\section{ISBN 978-966-170-048-1}




\section{MICT}

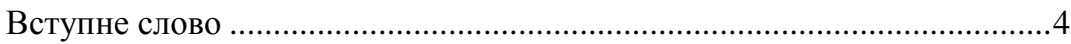

Padioнова I.Ф. Множинність сенсів економіки невизначеності та концепції і моделі публічного управління

Смельяненко Л.М., Захарова К.Ф. Форсайт в публічному управлінні як інструмент регулювання за умов економічної невизначеності .........31

Радіонова І.Ф., Мальковська Ю.Б. Інституційний дизайн макрофінансової безпеки для стабілізації національної економіки ......52

Усик В.І., Дзюбко В.В. Освітня політика та економічна невизначеність: прикладний аспект в контексті ринку нерухомості ....77

Радіонова I.Ф., Фаренюк Я.В. Аналіз на основі баз даних (Data Science) для управлінських рішень з урахуванням невизначеності на макро- та мікроекономічному рівні.

Mizус I.П. Інструментарій оцінювання корпоративного управління в акціонерних товариствах за умов економічної невизначеності........122

Коваль Я.С. Компаративний аналіз методів протидії легалізації доходів, одержаних злочинним шляхом.

Ананьсва О.О., Гофман М.О. Аналіз економіки підприємств у стані невизначеності: особливості інструментарію дослідження.

Пекна Г.Б. Конкурентна спроможність підприємств для визначеності економічних результатів

Андрєєва В.А. Релевантна оцінка нерухомого майна в протидії економічній невизначеності.

Потапенко Д.О., Троц І.В. Компаративний аналіз податкового забезпечення стабільності бізнесу: Україна vs Німеччина

Tроц I.B., Дзюбко В.B. Інноваційне підприємництво та стартапи у стабілізації бізнесу: кращий досвід та його застосування в Україні .....235

Красота О.В., Андрєєва В.A. Соціальне підприємництво як інструмент соціальної інклюзії за умов економічної невизначеності

Tonaл A.A., Піта Ю.A. Оптимізація структури та форм підприємництва для забезпечення стабільності національного ринку нерухомості .....272 


\section{ВСТУПНЕ СЛОВО}

3 назви цієї монографії стає зрозумілим, що вона присвячена невизначеності в економічній сфері. Те, який сенс вкладають автори цієї роботи в поняття «економічна невизначеність», розкривається власне змістом (структурою) монографії. Тлумаченню цього змісту присвячено й спеціальний (1-ий) розділ монографії. Але, попри очевидні речі, в монографії присутній ще один неочевидний аспект невизначеності. Саме про нього згадував всесвітньо визнаний український економіст M. I. Туган-Барановський ще на початку XX ст. У фундаментальній праці «Основи політичної економії», пояснюючи, що таке господарська діяльність, він зазначав таке: «...Незрозумілість в цьому висхідному пункті повинна внести невизначеність у все наступне». Тобто, невизначеність подається тут як наслідок (результат) незрозумілості. Остання є синонімом неусвідомленості, непоясненності, відсутності визнаних принципів пізнання і тлумачення. Незрозумілість продовжує продукувати економічну невизначеність. Зокрема, цей зв'язок - між незрозумілістю та економічною невизначеністю - реалізується в українській економіці. Тому, прагнучи усвідомити, пояснити, застосувати певні принципи дослідження національної економіки, автори цієї монографії врешті-решт сприяють й обмеженню невизначеності.

Власне побудова, тобто структура цієї роботи, віддзеркалює розроблений авторами підхід до пояснення змісту економічної невизначеності. Тому акцентуємо увагу читачів саме на цій побудові.

По-перше, структура монографії презентує два рівні прояву, відповідно, рівні дослідження та усвідомлення економічної невизначеності: загальний і особливий. Загальний рівень, який стосується економіки як цілого й пов'язаний із системою публічного управління нею, здебільшого, презентований у розділах 1-7. Натомість особливий, який виявляється в організації окремих видів підприємницької діяльності та в конкретних iii сферах, подано, переважно, в розділах 8-14. Зрозуміло, що такий поділ на загальне та особливе $\epsilon$ достатньо умовним. Адже зв'язок, залежність і взаємне проникнення цих двох рівнів $є$ незаперечними. Однак, виокремлення саме таких рівнів невизначеності стає доцільним, хоча б з огляду на необхідність застосування визнаного онтологічного (пізнавального) принципу.

По-друге, монографія побудована у такий спосіб, що в ії розділах віддзеркалено реально існуючі та актуальні прояви економічної невизначеності, $з$ одного боку, та інструменти ії (невизначеності) дослідження та обмеження - 3 іншого. 
В якості актуальних для української економіки проявів невизначеності в монографії подано такі:

- макрофінансові дисбаланси, щодо яких не створено інститутів запобігання та адекватного реагування (розділ 3);

- суперечлива освітня політика, яка не забезпечує нагромадження людського капіталу, відповідно до потреб економіки та суспільства (розділ 4);

- перманентне відтворення тіньової економіки з властивими їй нелегальними доходами, отримуваними злочинним шляхом (розділ 7);

- неприродно обмежена й, тому недостатня, конкурентна спроможність усієї національної економіки, окремих галузей та підприємств (розділ 9);

- надлишковий податковий тягар, який дестимулює виробників і платників податків (розділ 11);

- недієвість, здебільшого, формальність зусиль 3 переходу від традиційної до інноваційної моделі економіки (розділ 12);

- соціальна ексклюзія - відсутність необхідної залученості окремих груп та прошарків суспільства в економічне, соціальне, політичне життя (розділ 13);

- штучно уповільнене формування інфраструктури одного 3 найважливіших галузевих ринків національної економіки - ринку нерухомості (розділ 14).

Досліджено на предмет можливості використання в аналізі та в реагуванні на зміни ії масштабів, а також, частково, застосовано такі інструменти:

- форсайт як спосіб моделювання майбутнього та імплементації його окремих елементів у сьогоднішнє життя спільнот та суспільства (розділ 2);

- великі бази даних (Data Base) як інструментарій прийняття управлінських рішень на засадах виявлення неочевидних (прихованих), але реально існуючих суттєвих залежностей (розділ 5);

- методи якісного оцінювання корпоративного управління акціонерних підприємств та їх поєднання 3 методами кількісного оцінювання (розділ 6);

- комплексні методи аналізу ефективності підприємств 3 акцентом на оцінюванні невизначеності (ризиків) (розділ 8);

- релевантні методики оцінки нерухомого майна, здатні забезпечити максимальне врахування особливостей конкретного етапу економічного розвитку (розділ 10).

Особливістю цього дослідження стало акцентування уваги на одному з галузевих ринків. Ідеться про ринок нерухомого майна, 
проблеми організації якого висвітлено у трьох розділах (розділи $4,10,14$ ). Таке акцентування уваги пояснюється, крім об'єктивних, ще й суб'єктивними обставинами. Чотири співавтори цієї монографії не лише викладають навчальні дисципліни, пов'язані з ринком нерухомості, на освітніх програмах кафедри теоретичної та прикладної економіки Університету «КРОК», а й мають великий досвід роботи на цьому ринку.

Монографія $є$ результатом проведення колективного дослідження за темою «Національна економіка та економіки галузевих ринків в умовах інституційної невизначеності» №0120U100086.

Автори монографії вдячні Університету «КРОК» за можливість опублікувати результати досліджень у вигляді монографії.

Ми сподіваємося на реагування наукової, студентської спільноти, фахівців з управління на вихід у світ цієї монографії. Очікуємо на критичну, але справедливу оцінку результатів роботи авторського колективу. Будемо вдячні за таку оцінку та пропозиції з покращення змісту.

\section{Від авторів - науковий редактор монографії, д.е.н., професор Ірина Радіонова}

Грудень 2020 
Економіка невизначеності: зміст, оцінювання, регулювання

\title{
МНОЖИННІСТЬ СЕНСІВ ЕКОНОМІКИ НЕВИЗНАЧЕНОСТІ ТА КОНЦЕПЦІЇ І МОДЕЛІ ПУБЛІЧНОГО УПРАВЛІННЯ
}

\author{
Радіонова Ірина Федорівна, \\ доктор економічних наук, професор, \\ ДВНЗ Київський національний університет імені Вадима Гетьмана, \\ ВНЗ «Університет економіки та права «КРОК», \\ ORCID: https://orcid.org/0000-0002-0941-2867
}

Анотація. Цей розділ присвячено уточненню змісту поняття «економіка невизначеності» та інших близьких до нього понять. Виокремлено та ідентифіковано явище меж економіки невизначеності й здійснено спробу обгрунтування параметрів, за якими можуть оцінюватися ці межі. Такими параметрами визначено: «не-волатильність», раціональність очікувань, конкурентність економічного середовища, релевантність економічної політики та рівень ії інституціоналізації. Сформульовано гіпотезу про визначальний напрямок змін концепції публічного управління, які мають відбуватися під впливом зростання масштабів економіки невизначеності. Наведено аргументи на користь того, що адекватна реакція публічної політики на розширення меж економіки невизначеності могла б спиратися на ідеї двох концепцій публічного управління. Це - концепція публічного врядування (Governance) та концепція економічного націоналізму.

Ключові слова: економіка невизначеності; економічна теорія невизначеності; невизначеність, спричинена економічною політикою; політична невизначеність; концепції та моделі публічного управління.

Предметом аналізу цього монографічного дослідження загалом і цього розділу зокрема $\epsilon$ економіка невизначеності. На початковому етапі дослідження зазвичай виникає необхідність якомога більш точного окреслення змісту понять, якими оперуватимемо у процесі вирішення наукової проблеми. Йдеться передусім про власне зміст та взаємозв'язки принаймні чотирьох понять, а саме:

- економіка невизначеності як теорія - «Economics of uncertainty»;

- економічна невизначеність як фрагмент національної економіки «Economic uncertainty»;

- економічна невизначеність, спричинена політикою уряду «Policy-related economic uncertainty»;

- політична невизначеність - «Policy uncertainty».

Економіка невизначеності як теорія, або «Economics of uncertainty», пояснює феномен економічної невизначеності з використанням певного теоретичного та аналітичного інструментарію: гіпотез, припущень, логічних конструкцій, узагальнень тощо. Призначенням цієї частини 
економічної науки, на наш погляд, є визначення критеріїв, меж, причин, форм утілення, наслідків, способів відтворення економічних відносин з ознаками невизначеності.

Економічна невизначеність як фрагмент (складник) національної економіки, або «Еconomic uncertainty», - це економічні відносини 3 особливими характеристиками, властивостями та маркерами (індикаторами), придатними для оцінювання. Саме ці характеристики, властивості, маркери мають досліджуватися в межах тієї частини загальної економічної теорії, що визначається як «Economics of uncertainty».

Тлумачення змісту економічної невизначеності зазвичай починається з ідентифікації тих станів, через які вона виявляється [1]. Йдеться, зокрема, про високі рівні інфляції та значну волатильність цін, занизькі темпи зростання або ж кризові спади економіки, безробіття, несподівані структурні зміни, очікування дефолтів, девальвації національної валюти тощо. При спробах кількісного оцінювання рівня невизначеності та її наслідків дослідники часто «обмежують» іiї зміст певним переліком конкретних показників, через які, за їх уявленнями, невизначеність можна ідентифікувати [2].

«Економічна невизначеність, пов'язана 3 політикою» («Policy-related economic uncertainty») віддзеркалює той незаперечний i економетрично доведений факт, що політика уряду впливає на темпи економічного зростання, глибину економічних спадів тощо. Важливо виокремлювати та ідентифікувати економічну невизначеність, пов'язану власне 3 політикою, ще й тому, що існує інша невизначеність. Це невизначеність, спричинена об'єктивно існуючою економічною циклічністю. Невизначеність, спричинена економічними циклами, виявляється у тому, що, попри усвідомлення невідворотності циклічних змін, важко або й неможливо безпомилково передбачити низку економічних параметрів. Ідеться про час проходження пікових точок у піднесеннях i спадах, а також про їх «глибину», про тривалість окремих фаз циклу тощо [3; 4]. Попри те, що існує достатньо досконалий економетричний інструментарій передбачення змін, його технічні, інформаційні тощо обмеження також формують економічну невизначеність.

«Політична невизначеність» («Policy uncertainty») може трактуватися передусім як дії уряду в економічній сфері, які не мають необхідного обгрунтування та організаційно-правового забезпечення.

Політичну невизначеність доцільно тлумачити як інституційну незавершеність у діяльності творців (стейкхолдерів) політики. Інституційна незавершеність може мати такі типові прояви, як лакуни законодавства, відсутність чітко окреслених суспільних цінностей, обгрунтованих 
стратегій і програм, а також політичної волі до їх реалізації. Ї̈̈ можуть підсилювати недоліки комунікації в управлінській ієрархії та у взаєминах влади з суспільством. Політична невизначеність, окрім згаданих вад інституціоналізації, об'єктивно пов'язана 3 політичними виборчими циклами, 3 непередбачуваною політичною реакцію суспільства й окремих спільнот на дії влади у процесі подолання техногенних, екологічних, епідеміологічних тощо викликів.

Феномен політичної невизначеності є настільки очевидним та суттєвим для суспільства, що існує напрямок досліджень, пов'язаний 3 обгрунтуванням i застосуванням методик оцінювання політичної невизначеності. До прикладу, в роботі Baker S., Bloom N., Davis S. презентовано конструкцію індексу невизначеності економічної політики (EPU - Economic Policy Uncertainty) [5]. Останній застосовано для оцінювання ситуації у США та ще дванадцятьох розвинених країнах. Показовим $\epsilon$ те, що економічна політика потрактована в цій роботі як певний симбіоз фіскальної, монетарної та регуляторної політики. Відтак, економічна політика, щодо якої оцінюється рівень невизначеності, фрагментована (структурована) за найважливішими інструментами урядового впливу на економіку.

Акцент на зв'язку економічної політики та економіки невизначеності $€$ особливо важливим у нашому дослідженні 3 двох причин. По-перше, тому що «публічне управління» - словосполучення, яке використано в назві цього розділу - і $є$ здійсненням певної економічної політики. По-друге, суб'єкти публічної влади в особі іiї центральних та місцевих органів, здійснюючи певну економічну політику, можуть або сприяти досягненню більшої економічної визначеності, або, навпаки, розширювати межі економічної невизначеності.

У взаємозв'язку двох понять (явищ) - «економічної невизначеності» та «політичної невизначеності» - друге стає причиною першого, а саме: політична невизначеність спричиняє та посилює економічну невизначеність. Хоча існують свідчення і зворотного зв'язку, коли економічна невизначеність посилює політичну.

Як уже зазначено, економічна теорія невизначеності - «Economics of uncertainty» - покликана відповісти на принципове питання про критерії та межі (масштаби) економіки невизначеності. Фактично, у такий спосіб може досягатися уточнення змісту цього поняття (явища).

Ми припускаємо, що економіка невизначеності є фрагментом будь-якої національної економіки. Для її ідентифікації необхідні певні критерії (параметри) оцінювання. Теоретична конструкція, пропонована нами для пояснення меж, відповідно, - змісту економіки невизначеності, подана на рис. 1. 
«Не-волатильність»

Якість інституціоналізації

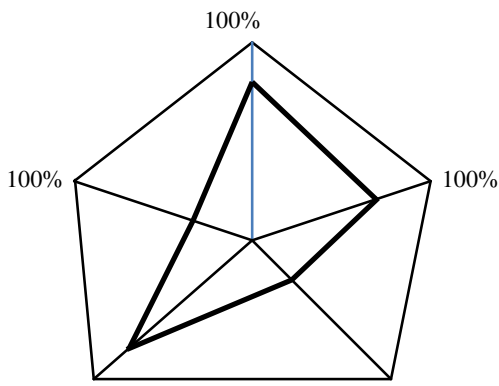

Раціональність

очікувань

Релевантність $100 \%$ політики

$100 \%$

«Конкурентність» середовища

\section{Рис. 1. Параметри і межі економіки невизначеності}

Джерело: розроблено автором самостійно.

За поданою на рис. 1 ідеєю, «економіка невизначеності»- це зона, що перебуває за межами фігури, окресленої чорним кольором. Усередині окресленої фігури знаходиться «зона визначеності», яка й формує осердя національної економіки. Наближення фактичних показників конкретної економіки, за п’ятьма параметрами, до позначки «100\%» означає, за нашою логікою, наближення до повної економічної визначеності. Натомість, віддалення від позначки «100\%» $є$ збільшенням зони економіки невизначеності.

Ми припускаємо, що зміст та межі економіки невизначеності як явища, об'єктивно притаманного будь-якій економіці, можуть визначатися за такими п'ятьма параметрами:

- «не-волатильність» економіки;

- раціональність очікувань економічних суб'єктів;

- конкурентність економічного середовища;

- релевантність економічної політики;

- якість інституалізації публічної влади.

Чи є підстави вважати, що перелік пропонованих параметрів для оцінювання невизначеності $€$ вичерпним? Звичайно, ні. Нові дослідження в цій царині виявлятимуть нові параметри та сприятимуть їх більш адекватній формалізації. Подовження й удосконалення переліку параметрів, імовірно, робитиме уявлення про економіку невизначеності більш обгрунтованими.

Для практичного застосування пропонованої теоретичної конструкції необхідна відповідь на питання про визначення так званої «точки перебування» в інтервалі від 0 до 100\% за кожним 3 п’ятьох пропонованих параметрів. Очевидно, що для цього можуть 
використовуватися прийоми оцінювання через порівняння, тобто бенчмаркінг. Останній, як відомо, передбачає виконання двох важливих передумов для відповідного застосування, а саме:

- наявність бази для порівняння;

- здійснення процедури нормування показників.

Базу для порівняння формують так звані стандартні значення показників. У якості таких можуть використовуватися кращі показники у відібраній для порівняння групі об'єктів або ж оптимальні значення показників, що визначені у вітчизняних або міжнародних нормативних документах та методиках.

Найпростішими формулами нормування, за якими може визначатися точка на інтервалі від 0 до 100\%, є ті, що фіксують міру відхилення фактичних значень параметрів від стандартних або ж відхилення фактичних значень від максимальних (мінімальних) у відібраній для порівняння групі об'єктів, а саме:

1) нормування показникастимулятора:

$$
\begin{aligned}
& y_{n}=\frac{x_{f}}{x_{s t}}, \\
& y_{n}=\frac{x_{\text {max }}-x_{f}}{x_{\max }-x_{\min }},
\end{aligned}
$$

2) нормування показникадестимулятора:

$$
\begin{aligned}
& y_{n}=\frac{x_{s t}}{x_{f}}, \\
& y_{n}=\frac{x_{f}-x_{\min }}{x_{\max }-x_{\min }},
\end{aligned}
$$

де $y_{n}$ - нормоване значення показника, $x_{f}$ - фактичне значення показника, $x_{s t}$ - стандартне (краще для певної групи, нормативне, оптимальне тощо) значення показника, $x_{\max }, x_{\min }-$ відповідно, максимальне та мінімальне значення показника у відібраній для порівняння групі об'єктів.

Більш складні формули нормування передбачають фактологічне обгрунтування й ідентифікацію певних інтервалів «нормальності» значень у таких межах, як, до прикладу, «оптимальне» та «задовільне», «задовільне» та «незадовільне», «незадовільне» та «критичне» тощо.

Залежно від того, у який спосіб формалізовано й репрезентовано стандартні (кращі, нормативні, оптимальні) значення, може застосовуватися або формула нормування для показника-стимулятора, або, навпаки, для показника-дестимулятора. Наприклад, у практиці управління застосовується показник «монопольної влади» для оцінювання стану певної сфери (ринку). Зрозуміло, що «конкурентність» та «монополізація» середовища $є$ протилежними за змістом явищами. Конкурентність звужує зону економіки визначеності, тобто є для неї дестимулятором. Натомість, монополізація розширює зону невизначеності, стаючи щодо неї стимулятором. 
Придатність пропонованої теоретичної конструкції (за рис. 1) до використання може обгрунтовуватися в процесі пояснення змісту та чинних практик (методик) вимірювання за п'ятьма згаданими параметрами: «не-волатильності», раціональності, конкурентності середовища, релевантності оцінювання та якості інституціоналізації.

Волатильність у найбільш загальному сенсі може тлумачитися як інтенсивність коливань, як збільшення міри відхилень (дисперсія) фактичних значень від сформованих трендів тощо. Відповідно, неволатильність має означати послаблення коливань та зменшення відхилень. Ідентифікація волатильності на національному і глобальному рівнях здебільшого здійснюється у формі інтегрального індексного оцінювання з визначенням відсоткової зміни (дисперсіі) певного індексу. Як правило, йдеться про індекси цін ринків, насамперед - фондових. За таким же підходом може визначатися дисперсія показників темпу економічного зростання, рівня безробіття, загального рівня цін тощо.

Зразок оцінювання волатильності з використанням індексів цін фондового ринку подано, наприклад, у роботі, яка присвячена індексу VIX та його порівнянню з іншими індексами волатильності - S\&P 100, $\mathrm{S} \& \mathrm{P} 500, \mathrm{VSTOOX}[6]$. Маючи показники волатильності, за відібраною для порівняння групою країн можна оцінювати відносний рівень волатильності національної економіки.

Раціональність очікувань, як параметр для оцінювання економіки невизначеності, спирається на одну з найбільш впливових економічних концепцій XX ст. - теорію раціональних сподівань. Як відомо, ідея раціональності в економічній сфері сформульована Muth J. у 1960-х роках. Вона була поширена й імплементована в макроекономічну теорію та теорію економічної політики видатними економістами Lucas R., Sargent T., Walles N. [7], Taylor J. [8] y 1970-x - 1990-x pp.

Дотичність ідеї раціональності до оцінювання економіки невизначеності пов'язана, на наш погляд, з такою обставиною. У теорії раціональних очікувань використовується фундаментальне припущення про те, що раціональність - це здатність на підставі доступної інформації передбачати те, що дійсно стається. Звідси випливає: чим вищий рівень раціональності, тим менша економічна невизначеність $\mathrm{i}$, навпаки, при збільшенні нераціональності у поведінці економічних суб'єктів, межі невизначеності мають розширюватися. Ми цілком погоджуємося $з$ узагальненням українського дослідника О. Ватаманюка, який влучно зауважив, що найбільша кількість відхилень від рачіональності фіксується саме у ситуаціях невизначеності, коли люди починають спрощувати для себе завдання вибору, керуючись певними «евристичними принципами» [9].

Важливо те, що феномен раціональності не лише аналізується 3 якісного боку, а й кількісно оцінюється. Маємо приклад оцінювання 
раціональності прогнозів МВФ та ОЕСР щодо дефіцитів бюджетів країн G7 на основі економетричних моделей. При цьому висновок про раціональність робиться на підставі вимірювання похибки прогнозів [10]. Такий підхід до кількісного оцінювання раціональності - за похибкою прогнозів - $\epsilon$ цілком обгрунтованим. Адже нездатність або обмежена здатність передбачати, відповідно, - збільшення похибки прогнозу є проявом нераціональності у тому первинному сенсі, який закладався творцями теорії раціональних сподівань.

Конкурентність економічного середовища є достатньо контроверсійним параметром в оцінюванні економічної невизначеності. На перший погляд, конкуренція, ототожнювана зі стихією ринку, мала б означати збільшення невизначеності. Натомість, монополія мала б пов'язуватися зі зростанням визначеності. 3 позицій економіки окремого суб'єкта, останнє твердження виглядає правдивим. Однак, з позицій усієї економіки, висновок мав би бути протилежним: масштаби економіки невизначеності збільшуються при згортанні конкуренції, при ускладненні умов провадження бізнесу, при збільшенні рівня монополізації. Це може обгрунтовуватися хоча б тим, що конкурентні умови - це певна передбачуваність результатів згідно із законами попиту та пропозиції. Натомість, монополізоване середовище породжує явище, яке можна охарактеризувати як «непередбачуваність домінування». Це невизначеність, пов'язана 3 неможливістю консенсусу загальних національних економічних інтересів. Відсутність консенсусу інтересів $\epsilon$ актуальним явищем української економіки, побудованої на засадах «олігархічної моделі». Остання означає монополізацію економічних сфер у поєднанні з домінуванням у політиці декількох олігархічних груп.

В арсеналі теорії галузевих ринків $є$ достатньо апробований інструментарій оцінювання того, що $є$ близьким за змістом до параметру «конкурентність економічного середовища». Йдеться, зокрема, про вимірник концентрації бізнесу на певному ринку (індекс ГерфіндаляГіршмана) та показник ринкової влади монополіста (коефіцієнт Лернера). Але згадані показники, що придатні для оцінювання окремої галузі (ринку), не задовольняють вимоги оцінювання всього економічного середовища. Більшою мірою такій вимозі відповідає оцінювання i ранжування країн світу за Індексом економічної свободи (Index of Economic Freedom). Останній, як відомо, розроблено за ініціативи Тhe Heritage Foundation and The Wall Street Journal та використовується вже 25 років поспіль [11].

На користь придатності Індексу економічної свободи для оцінювання конкурентності всього економічного середовища свідчить власне конструкція індексу. Він побудований на основі чотирьох складників-субіндексів, які віддзеркалюють важливі моменти формування конкурентного середовища. Такими є: 1) правові основи підприємництва; 
2) способи державного регулювання; 3) свободи економічних суб'єктів;

4) відкритість ринків. У методиці розрахунку Індексу економічної свободи йдеться про такі терміни та таке змістове наповнення чотирьох складників:

- «верховенство права» (права власності, судова ефективність, цілісність уряду);

- «масштаби уряду» (податкове навантаження на платників, державні витрати, фіскальна стабільність);

- «ефективність регулювання» (свобода підприємництва, свобода праці та грошового ринку);

- «відкритість ринку» (свобода торгівлі, інвестицій та фінансова свобода).

Використовуючи значення розрахованого для всіх країн світу (180 позицій) Індексу економічної свободи за конкретний рік, можна здійснювати процедуру нормування. Не виключено, що в якості стандарту можуть використовуватися найкращі світові значення індексу. В такий спосіб визначатиметься точка на осі від 0 до $100 \%$ за параметром «конкурентність економічного середовища».

Ми припускаємо, що в оцінюванні параметру «конкурентності економічного середовища» можна обмежитися певними складниками Індексу економічної свободи. До прикладу, це можуть бути лише два складники індексу, а саме: «ефективність регулювання» та «відкритість ринку». В будь-якому випадку, необхідним стає обгрунтування вибору на підставі певних припущень.

Релевантність політики - це ії відповідність «природі економічних процесів» і конкретним умовам, що склалися. Релевантність економічної політики може мати якісне (теоретичне) тлумачення та кількісне (фактологічне, емпіричне) оцінювання.

Якісне оцінювання релевантності економічної політики означає передбачення наслідків прийняття рішень у фіскальній, монетарній, зовнішньоекономічній тощо сферах на грунті певних теоретичних конструкцій (моделей). Такі модельні конструкції репрезентовані, зокрема, в кожному підручнику з макроекономіки. Вони ускладнюються 3 переходом від базового до вищого рівня макроекономіки остільки, оскільки в теоретичних моделях починає враховуватися ширше коло умов та припущень. Отже, теоретичне оцінювання релевантності політики $є$ порівнянням фактичних дій національних регуляторів економіки з логікою дій, за певними модельними конструкціями. Фактично, йдеться про відповідь на питання про ймовірні результати або втрати від економічної політики уряду, з урахуванням можливих інструментів впливу та певних обставин їх застосування, з огляду на логіку теоретичних моделей. 
Теоретичне оцінювання $\epsilon$ необхідним, але недостатнім для визначення рівня релевантності політики. Адже на його (теоретичного оцінювання) основі, можуть бути зроблені лише три висновки щодо політики: ймовірно, може бути «результативною», «мало результативною» або «не результативною». Зрозуміло, що лише такі три висновки щодо політики обмежують можливості оцінювання масштабів економіки невизначеності.

Прикладне, або емпіричне, оцінювання релевантності може існувати як складник так званого «циклу реалізації економічної політики». Для цього, як мінімум, має існувати сам «цикл політики» в діяльності уряду. Цикл зазвичай охоплює такі етапи: обгрунтування (ідентифікації цільових показників, інструментів впливу на економіку, оцінювання ресурсів), моніторингу, коригування, оцінювання результатів.

Про оцінювання, як про складник політичного циклу, йдеться, наприклад, в аналітичних матеріалах ОЕСР. Матеріали призначені для розробки особливого керівництва 3 самооцінювання країнами ОЕСР обгрунтованості державної політики (Draft Policy Framework on Sound Public Governance OECD) [12].

Якщо згадане керівництво 3 оцінювання обгрунтованості (релевантності) політики для країн ОЕСР виявляється заскладним для інших країн у повному його обсязі, то можливе його часткове використання. Йдеться, наприклад, про оцінювання через відхилення цільових показників фіскальної, монетарної, зовнішньоекономічної політики уряду від фактично досягнутих показників. У цьому випадку нормування може здійснюватися на основі припущення, що стандартними є саме цілььові значення показників. На користь такого припущення свідчить, зокрема, те, що досягнення визначених урядом цілей ідентифікується як найважливіша характеристика політики [13].

У дослідженні релевантності політики може бути використаний і підхід на основі оцінювання процедур політики. Сучасним прикладом такого підходу є міжнародний проєкт Digiwhist [14]. Його реалізація передбачає відносне (шляхом порівняння) оцінювання прозорості фіскальної сфери, а також дотримання тендерних процедур, успішності боротьби з корупцією у публічному секторі.

Ймовірно, що оцінювання релевантності політики на основі емпіричного дослідження обгрунтованості їі цілей та процедур мають бути не альтернативними, а взаємно доповнювальними підходами, тобто мають застосовуватися одночасно.

Якість інституалізації публічного управління - явище, що віддзеркалює процес реалізації політики. Інституалізація в публічному управлінні, за нашим припущенням, охоплює правила прийняття рішень у публічній сфері, процедури, алгоритми дій та нормативи 
стимулювання й обмеження, віддзеркалені у нормах права та забезпечені певними інститутами (організаційними структурами).

У науковому обігу перебувають достатньо відмінні визначення інституалізації [15]. Існують різні застосування цього терміна щодо різних сфер у різних країнах [16]. У цій монографії також подано розділ, присвячений інституціоналізації, а саме: інституційному дизайну макрофінансової безпеки [17]. Попри відмінності акцентів у визначеннях змісту інституціоналізації, здебільшого вона пов'язується з правилами, процедурами, правом, інститутами (організаційними структурами) влади.

Для кількісного оцінювання рівня інституціоналізації може використовуватися конструкція Індексу глобальної конкурентоспроможності (Global Competitiveness Index - GCI). ' Останній $є$ інтегральним вимірником, створеним під егідою Світового економічного форуму (World Economic Forum). Індекс охоплює 103 показники, об'єднані у 12 груп для визначення 12-х субіндексів. Перший із субіндексів інтегрального індексу GCI називається «Інститути» («Institutions») i, на наш погляд, може використовуватися для оцінювання пропонованого нами показника «Якість інституціоналізації».

За пропонованою Світовим економічним форумом методикою, субіндекс «Інститути» охоплює загалом 21 показник, 16 з яких стосуються інститутів саме публічної влади, а інші 5 - приватних інститутів. Власне оцінювання інститутів публічної влади, яке нас цікавить, передбачає виокремлення п’ятьох груп показників 3 такими означеннями та змістом:

- «майнові права» (захист прав власності загалом та інтелектуальної зокрема);

- «етика та корупція» (корупційне використання державних коштів, довіра до влади, корупційні виплати і хабарі);

- «неправомірні впливи» (незалежність судової системи та фаворитизм у державних рішеннях);

- «результативність державного сектору» (марнотратство у державних витратах, тягар державного регулювання, результативність правової бази при вирішенні суперечок та оскарженні рішень, прозорість формування публічної політики);

- «безпека» (бізнес-витрати на тероризм, злочини та насильство, масштаби організованої злочинності, надійність поліції).

Використання даних про зміну місця країни у світовому рейтингу за статтею «GCI 4.0: Pillar 1: Institutions» дає можливість здійснювати нормування, припускаючи, наприклад, що стандартом $є$ значення субіндексу кращої країни. До прикладу, таке порівняння мало б

* Інституційний дизайн макрофінансової безпеки для стабілізації національної економіки. 
ураховувати те, що місце України, за субіндексом «Інститути», змінювалося у 2017, 2018 та 2019 роках, відповідно, так: 115, 110 та 104 місце [18].

Економічна політика та моделі публічного управління не можуть не реагувати на економічну невизначеність. На користь цього твердження свідчить, зокрема, помічений дослідниками зв’ язок: збільшення невизначеності зменшує довіру до національних регуляторів (до прикладу, до центрального банку). Це спричиняє макроекономічний наслідок у вигляді скорочення витрат домашніх господарств і підприємцівінвесторів [19].

Непередбачуваність ситуації, пов’язаної з «Covid-19», викликала новий інтерес до проблеми економічної невизначеності. Більш детально стали досліджуватися не лише їі прояви в економіках окремих країн [20], а й реакції публічної влади на зростання невизначеності, а також досвід протидії економічній кризі з боку національних урядів [21].

Реагування публічної влади на посилення економічної невизначеності мало б розпочинатися 3 імплементації безпекового параметру в систему першочергових цінностей. Ідеться не тільки про реагування національних регуляторів на зміни окремих показників економічної безпеки. Ймовірно, що на часі створення концепції публічного управління, яка б віддзеркалювала факт нових масштабів економіки невизначеності. У руслі створення такої концепції проблема оцінювання масштабів невизначеності, відповідно, відбору параметрів для оцінювання стає першочерговою. Тому наша спроба обгрунтування конкретних параметрів - «не-волатильності», раціональності очікувань, конкурентності середовища, релевантності політики та якості інституціоналізації - може розглядатися як один з кроків на шляху до створення такої концепції.

Так званий безпековий параметр як цінність (і мета) публічної влади в контексті оптимізації масштабів економіки невизначеності, 3 урахуванням пропонованих нами параметрів, мав би виявлятися у таких діях:

- запобігання та протидія загрозливій для цілісності національної економіки волатильності;

- формування раціональних очікувань, передусім через збільшення довіри до дій влади та її здатності передбачати перебіг подій;

- обмеження монополізму та сприяння конкурентності економічного середовища;

- формування обгрунтованого, тобто релевантного, політичного циклу 3 послідовними та передбачуваними діями національних регуляторів;

- дотримання правил, процедур та визначених владою нормативів у економічній сфері.

Якщо безпека, ідентифікована як оптимізація масштабів невизначеності, ставатиме пріоритетом (метою) публічної влади, то це 
може змінювати економічну політику концептуально. Адже йтиметься про формування нового альтернативного вибору, відповідно - про врахування модифікованих координат політики. В якості таких координат, на наш погляд, можуть розглядатися: «Добробут (соціальна захищеність)», «Розвиток (інвестиції та інновації)», «Безпека (економічна визначеність)». Взаємозв'язок згаданих альтернативних цілей i, відповідно, координат політики подано на рис. 2.

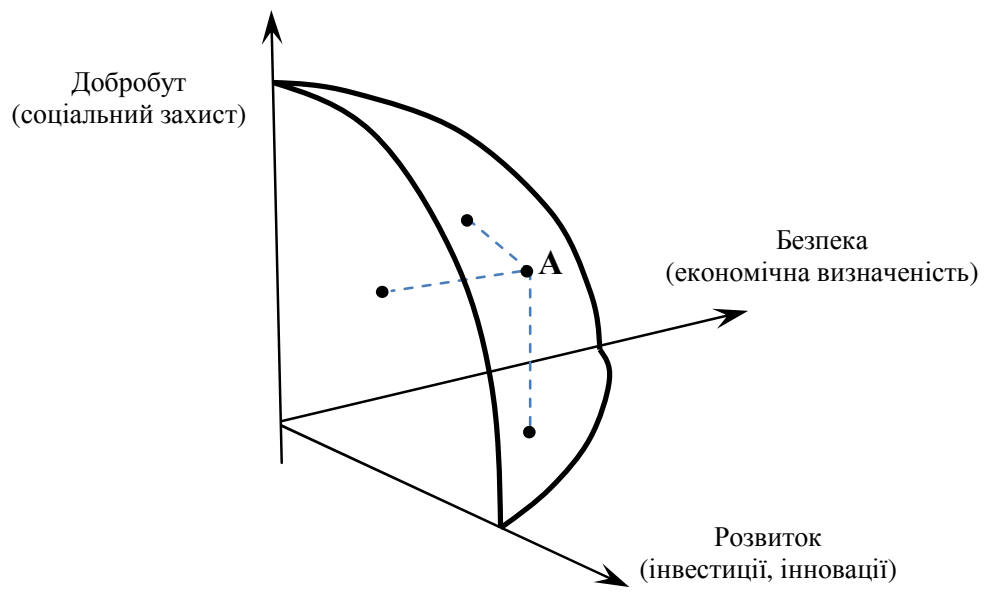

Рис. 2. Модель економічної політики як результату вибору в координатах трьох цілей

Джерело: створено автором самостійно.

На рис. 2 презентовано ідею про формування економічної політики $з$ урахуванням трьох цілей. Дві 3 них - «Добробут (соціальна захищеність)», «Розвиток (інвестиції та інновації)»- можна вважати «традиційними». Їх традиційність виявляється у тому, що зазвичай в якості альтернатив для ілюстрації вибору, за обмежених ресурсів, розглядаються товари «для споживання» та товари «для інвестування». Таке припущення, зокрема, використовувалося в теоретичній конструкції 3 назвою «функція соціального добробуту» («Social welfare function») або ж «крива суспільної байдужості» (Community indifference curve) [22]. Зрозуміло, що «товари для споживання» корелюють 3 поняттям «добробут», а «товари для інвестування» - 3 поняттям «розвиток». Третя ціль - «Безпека (економічна визначеність)» - не $\epsilon$ «традиційною». Вона не використовується у відомих теоретичних конструкціях: а) для пояснення суспільного вибору, б) поряд з двома іншими цілями в якості третьої компоненти вибору. 
Фундаментальні ідеї, покладені в основу теоретичних конструкцій «функції соціального добробуту» та «кривої суспільної байдужості», на наш погляд, можуть використовуватися для ілюстрації прийняття рішень публічною владою при виборі з урахуванням трьох цілей.

У пропонованій нами теоретичній конструкції (рис. 2) кожна 3 трьох кривих (і функцій) виконує таку пояснювальну роль:

- ілюструє межу можливостей, перевищення якої недосяжне, 3 огляду на наявні ресурси;

- $є$ геометричним місцем точок, кожна 3 яких презентує один 3 варіантів вибору з двох альтернатив, які (варіанти) $є$ однаково корисними для учасників політичного процесу.

За змістом координат, у яких побудовано три криві, їх можна було б визначати так:

- «функція соціальних можливостей» (у координатах: «Добробут (соціальна захищеність)» - «Розвиток (інвестиції та інновації)»);

- «функція виробничих можливостей» (у координатах: «Розвиток (інвестиції та інновації)» - «Безпека (економічна визначеність)»);

- «функція безпекових можливостей» (у координатах: «Безпека (економічна визначеність)»- «Добробут (соціальна захищеність)»).

Проблема оптимального вибору за трьома цілями політики, як ілюстровано на графіку рис. 1, пов'язана не з наближенням до так званих «кривих можливостей», а 3 рухом у бік площини, утвореної цими кривими. Фактично, постає завдання «не-виходу» за об'єктивні межі, окреслені трьома кривими, які утворюють складну площину. Складність знаходження параметрів точки вибору (точка А на рис. 2), що максимально наближалася б до цієї площини, лишень ілюструє більшу складність вибору «за трьома цілями» у порівнянні з вибором «за двома цілями».

На грунті сформованих уявлень про зміст економіки невизначеності можна оцінювати концепції (моделі) публічного управління, за їх придатністю відповідати на виклики невизначеності. У зв'язку з цим доцільно розрізняти два прояви невизначеності, а саме: невизначеність у процесах; невизначеність у результатах.

На наш погляд, найбільш адекватну реакцію системи управління на невизначеність у економічних процесах забезпечує концепція публічного управління Governance. Ймовірно, що найближчим українським відповідником цього англійського терміна $є$ термін «концепція публічного врядування».

Власне концепції публічного врядування Governance історично й логічно передувала інша концепція - Governvent. Українським відповідником останньої $є$ «державне управління».

Попри те, що згадані концепції - Governvent та Governance пов'язані між собою, вони мають принципові відмінності. Їх 
пов'язаність виявляється у тому, що обидві вони є управлінськими, реалізуються в публічній царині та стосуються одного об'єкта економіки - на загальнонаціональному (макроекономічному) рівні.

Відмінності між Governvent та Governance пов'язані передусім зі співвідношенням змістів близьких, але не тотожних понять (явищ), а саме: «публічне» та «державне», «врядування» та «управління». Оскільки власне уточнення змісту згаданих понять виходить за межі нашого дослідження, ми лише репрезентуємо своє бачення цього співвідношення у стислому (формалізованому) вигляді. На наш погляд, співвідношення може подаватися так:

$$
\begin{gathered}
\text { «публічне»> «державне», } \\
\text { «врядування»> «управління». }
\end{gathered}
$$

Особливий зміст концепції публічного врядування Governance найкраще виявляється при його порівнянні зі змістом концепції державного управління Governvent. Це порівняння подано на рис. 3.

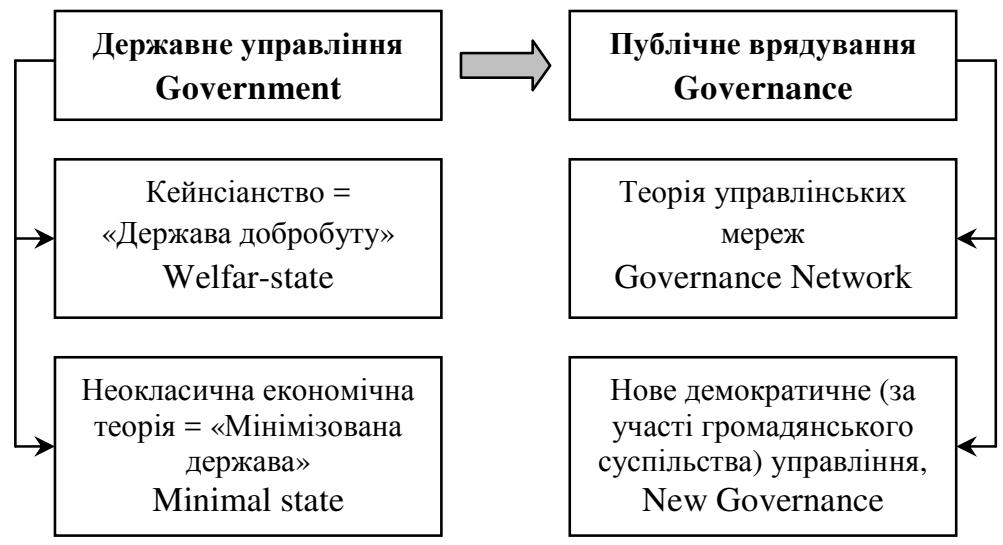

\section{Рис. 3. Порівняння концепцій управління економікою на загальнонаціональному рівні}

Джерело: створено автором самостійно.

Перехід від концепції державного управління (Government) середини XX ст. до концепції публічного врядування (Governance) 1990-х - початку XX ст. стимульований так званими «лакунами» або «провалами» держави. Йдеться про те, що традиційне управління середини XX ст. дедалі більше виявляло часткову неспроможність держави у вирішенні низки економічних та соціальних проблем. Тому виникає потреба у формуванні нових підходів до публічного управління на загальнонаціональному рівні та у впровадженні нових практик управління. 
Принципові відмінності між Government та Governance можна ідентифікувати на основі порівняльного аналізу тих теорій, які складають основний зміст двох альтернативних концепцій.

Концепція Government, попри відмінності кейнсіанства та неокласичної теорії, на основі яких вона розвинулася, в обох випадках дає відповіді на подібні питання, а саме:

- за створення яких суспільних благ має відповідати держава, які ресурси при цьому можуть використовуватися, відтак, якими $є$ об'єктивні економічні межі держави;

- 3 використанням яких інструментів мають досягатися визначені урядами цілі економічної політики, які інструменти державного регулювання та в яких випадках виявляють найбільшу результативність, а в яких, навпаки, стають недоречними;

- як мають поєднуватися в економічній політиці урядів фіскальні, монетарні та регуляторні (адміністративні) інструменти, яких правил політики при цьому доцільно дотримуватися.

Концепція Governance стосується дещо інших, порівняно 3 Government, управлінських акцентів. Попри це, в практиці реалізації ідей Governance не можна уникнути використання надбань концепції Government. Особливо, це стосується сформульованих правил застосування інструментів державного регулювання економіки, а також передбачення та оцінювання економічних результатів діяльності урядів.

Загальні засади концепції Governance віддзеркалено в документах ЄC. Ідеться, наприклад, про звіт, у якому подано фундаментальні принципи управління на засадах Governance. Це - принципи відкритості, участі, підзвітності, ефективності та узгодженості дій [23]. 3 цього переліку випливає висновок про акцентування уваги в теоретичному інструментарії концепції Governance саме на процесуальному аспекті управління.

Особливості концепції Governance розкриваються у численних джерелах [24; 25], зокрема, присвячених аналізу теорій, що формують іiї зміст. Це - теорія управлінських мереж (Governance Network) [26] та теорія нового демократичного управління з залученням громадянського суспільства (New Governance [27]).

Найбільш оригінальні ідеї-відповіді щодо принципових питань організації управлінського процесу, які сформувалися в межах згаданих теорій (Governance Network та New Governance), на наш погляд, є такими:

- дотримання правил, алгоритмів, проиедур доцільної взаємодії суб'єктів політики, а також демократичність процедур апріорі робить іiі (політику) ефективною;

- політика має оцінюватися не стільки за економічними та соціальними результатами, скільки за якістю дотримання процедур; 
- економіка потребує не керування, а спрямування з боку органів влади, які покликані формувати багаторівневі зв'язки (мережі), що охоплюють та імплементують в управлінський процес не лише органи влади, а й громадянське суспільство;

- демократичність процедур досягається через численні інструменти участі громадян - публічні дебати, громадські ініціативи, соціологічні дослідження щодо можливих реакцій на дії влади та щодо очікувань спільнот тощо;

- одним 3 ефективних засобів дотримання демократичності управлінських процесів стає використання цифрових технологій та формування системи електронного врядування (e-Governance [28]).

Ми припускаємо, що більший потенціал концепції Governance щодо адекватного реагування на виклики зростання масштабів економіки невизначеності пов'язаний 3 так званим «розширенням змістів». Це «розширення» ілюстровано на рис. 4.

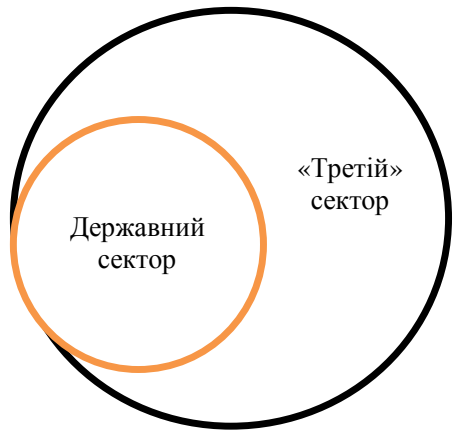

Рис. 4а. Публічна сфера

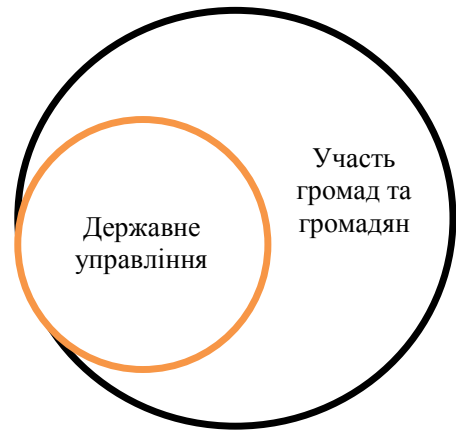

Рис. 4б. Врядування

Рис. 4. «Розширення змістів» у межах концепції публічного врядування Governance

Джерело: створено автором самостійно.

На рис. 4 візуалізовано ідею про те, що концепція (і практика) Governance подає управлінський процес «у ширшому сенсі». Тобто, йдеться про трактування публічної сфери у складі й державного, і «третього» (громадянського) сектору. Відповідно, врядування трактується як поєднання й системи державного управління, й системи участі громадян у публічному управлінні. Відтак, формується додатковий сегмент і додаткові можливості реагування на економічну невизначеність.

Обгрунтованість ідеї «розширення змістів» можна аргументувати, спираючись на факти і приклади обмеження невизначеності в українській 
економіці. Маємо на увазі те, що економічна неспроможність Української держави в найбільш критичні моменти невизначеності компенсується участю українського суспільства. Громадянське суспільство перманентно використовує різні форми компенсації економічної неспроможності держави. Йдеться про «самокошт» для інноваційних та безпекових проєктів, благодійництво та волонтерство в соціальному захисті населення при недофінансуванні медицини, освіти, культури, а також у сфері національної безпеки, при бездіяльності органів влади щодо запобігання економічним злочинам тощо.

Адекватне реагування на невизначеність результатів, на наш погляд, забезпечується практичним використанням ідей концепції економічного націоналізму.

Як відомо, концепція економічного націоналізму сформувалася в межах «історичної школи» економіки XIX ст. Для обгрунтування придатності цієї концепції відповідати на виклики економіки невизначеності доцільно зосередити увагу на двох обставинах. Поперше, на історичних умовах, в яких формувалися й «історична школа» загалом, і концепція економічного націоналізму зокрема. Подруге, важливо поглянути на ідеї засновника концепції економічного націоналізму Фрідріха Ліста під кутом зору тих висновків, які мають прикладну цінність і сьогодні.

«Історична школа» економіки виникає на теренах Німеччини першої половини XIX ст. саме в той час, коли для країни актуалізуються декілька проблем невизначеності результату. Йдеться, по-перше, про збереження національної ідентичності та економічної цілісності країни. По-друге, життєво важливим стає опанування певного місця у світовій економіці на тлі домінування індустріально розвиненої імперської Англії. Зрозуміло, що пануюча на той час концепція лібералізму й вільної торгівлі, пропонована англійською школою класичної політичної економії, не могла відповідати національним інтересам економічно слабкої Німеччини.

У науковому спадку засновника концепції економічного націоналізму Ф. Ліста (1789 - 1846) знаходимо низку ідей, які не втратили своєї важливості, крім іншого, й тому, що активно втілювалися впродовж XX ст. та продовжують втілюватися донині. Ці ідеї й ці практики стали достойною альтернативою ліберальним поглядам. Вони успішно використовувалися амбітними країнами, які долали відставання у соціально-економічному розвитку та наслідки економічного колоніалізму [29]. Проблема економічного колоніалізму, у поєднанні з високим рівнем економічної невизначеності, залишається актуальною для української економіки в XXI ст. 
Ідеї концепції економічного націоналізму в роботах Ф. Ліста" та пов'язані з ними узагальнення щодо економічної невизначеності, які 3 цих ідей випливають, на наш погляд, можуть бути подані так:

1. Iдея: економіка кожної країни розвивається за особливими законами, реалізація яких покликана забезпечити розвиток продуктивних сил саме конкретної нації в конкретний час.

Висновок: спроба реалізації загальних, а не особливих законів на конкретних теренах може спричиняти гальмування розвитку національних продуктивних сил та посилення економічної невизначеності.

2. Iдея: продуктивні сили нації не обмежуються лише матеріальними складниками - засобами виробництва та природними ресурсами. Вони охоплюють і додатково набуті здібності людей, а також систему урядування, мораль, мистецтво, судочинство. Важливим чинником економічного зростання стає «духовне знання» остільки, оскільки воно сприяє формуванню нових продуктивних сил.

Висновок: брак матеріальних продуктивних сил та пов'язана 3 цим невизначеність, властива країнам з нижчим рівнем розвитку, може компенсуватися використанням потенціалу суспільних інститутів й інститутів державної влади.

3. Ідея: економічна політика уряду має бути активною i наступальною. Важливим проявом активізму держави стає «виховний протекціонізм», стимулювання вітчизняного виробництва та обмеження імпорту в задоволенні національних потреб. Завданням уряду має бути інвестування в інфраструктуру, узгодження взаємодії окремих ланок національної економіки.

Висновок: розвиток національної економіки, як передумова вищого рівня економічної визначеності, забезпечується державою, наділеною функціями захисту, стимулювання, гарантування цілісності національної економіки.

4. Iдея: теорія і практика «вільної торгівлі» стає інструментом економічного домінування більш економічно розвинених націй щодо тих, які мають нижчий рівень розвитку. «Вільна конкуренція між двома цивілізованими націями, - писав Ф. Ліст 170 років тому, - може

\footnotetext{
* Дослідником економічного колоніалізму стосовно України був відомий у світі, але маловідомий в Україні, американський професор українського походження Всеволод Голубничий. Його робота «Теорія економічного колоніялізму та ії стосунок до України» введена в науковий обіг завдяки дослідженню українських науковців, репрезентованому в роботі «Політична економія суспільного прогресу» Всеволода Голубничого у двох томах [30].

Для презентації ідей Ф. Ліста ми скористалися роботою Злупка С. М. [31, с. 354-372] у частині, присвяченій Німецькій історичній школі. Згадана робота цікава тим, що ії автор не лише спирається на оригінальну роботу самого Ф. Ліста (Лист Ф. Национальная система политической экономии. СПб, 1891), а й використовує аналіз цієї історичної спадщини німецьких вчених та докторську роботу українського науковця, виконану в Українському Вільному Університеті в Мюнхені (Німеччина).
} 
бути взаємно корисною лише тоді, коли вони перебувають приблизно на одному рівні промислового розвитку...».

Висновок: застосування на практиці принципів вільної торгівлі для національних економік з нижчим рівнем розвитку може спричиняти консервування відставання та посилення економічної невизначеності.

Аргументи на користь придатності концепції економічного націоналізму для використання при досягненні вищого рівня розвитку та більшої визначеності економічних результатів знаходимо в успішних моделях економічного відродження окремих країн. ${ }^{* *}$ Аналіз національних моделей з позицій реалізації лише двох ідей економічного націоналізму національної єдності як джерела для розвитку продуктивних сил та активності держави у реалізації національних економічних проєктів подано в аналітичній табл. 1.

Таблиця 1

\section{Дві $з$ ідей концепції економічного націоналізму в моделях публічного управління окремих країн}

\begin{tabular}{|c|c|}
\hline $\begin{array}{l}\text { Ідеї концепції } \\
\text { економічного } \\
\text { націоналізму }\end{array}$ & $\begin{array}{c}\text { Приклади реалізації ідей концепції економічного } \\
\text { націоналізму в успішних моделях відродження } \\
\text { національних економік }\end{array}$ \\
\hline \multirow[t]{3}{*}{$\begin{array}{c}\text { Національна єдність, } \\
\text { подолання соціального } \\
\text { відчуження як } \\
\text { «додаткова продуктивна } \\
\text { сила» та джерело } \\
\text { економічного зростання }\end{array}$} & $\begin{array}{l}\text { Модель «Державного соціалізму» в Німеччині } 1880-x- \\
1890-x \text { рр. за часів Отто фон Бісмарка: подолання відчуження } \\
\text { робітничого класу та його опозиції до Німецької держави } \\
\text { шляхом ухвалення і реалізації низки законів соціального } \\
\text { захисту в царині медицини (1883), пенсійного страхування } \\
\text { (1889), захисту праці (1891).*** }\end{array}$ \\
\hline & $\begin{array}{l}\text { Модель «Етичного (конфуціанського) капіталізму» першої } \\
\text { третини ХХ ст., за часів японського лідера Е. Shibusava: } \\
\text { подолання відчуження через формування «позитивної } \\
\text { ідентичності національного бізнесу» шляхом створення ним } \\
\text { у взаємодії з японською державою благодійних організацій, } \\
\text { реалізації соціальних програм, зокрема, оновлення системи } \\
\text { шкільництва тощо [34]. }\end{array}$ \\
\hline & $\begin{array}{l}\text { Модель «Французького солідаризму» П'ятої Республіки } \\
\text { після прийняття Конституції } 1958 \text { р., за президентства } \\
\text { Шарля де Голля: вибіркова підтримка найбільш економічно } \\
\text { відсталих регіонів, подолання відчуження між суспільними } \\
\text { верствами через «систему участі», «соціальні ліфти», } \\
\text { включно з «ліфтами» у системі державної служби, реформування } \\
\text { освітньої системи в напрямку гарантування якісної освіти } \\
\text { для всіх [35]. }\end{array}$ \\
\hline
\end{tabular}

\footnotetext{
* В аналізі використана робота Панченка В. [32, с. 6-12] у частині «Теоретичні підвалини економічної доктрини ОУН, або Ф. Ліст проти К. Маркса».

** Переклад В. Панченка з List Frederik National System of Political Economy. Philadelphia: J. B. Lippincott \& Co, 1856. P. 77.

**** Узагальнюючі матеріали про успішні моделі на засадах економічного націоналізму подано в роботі Аналітичного центру «Українські студії стратегічних досліджень» [33].
} 
Продовження табл. 1

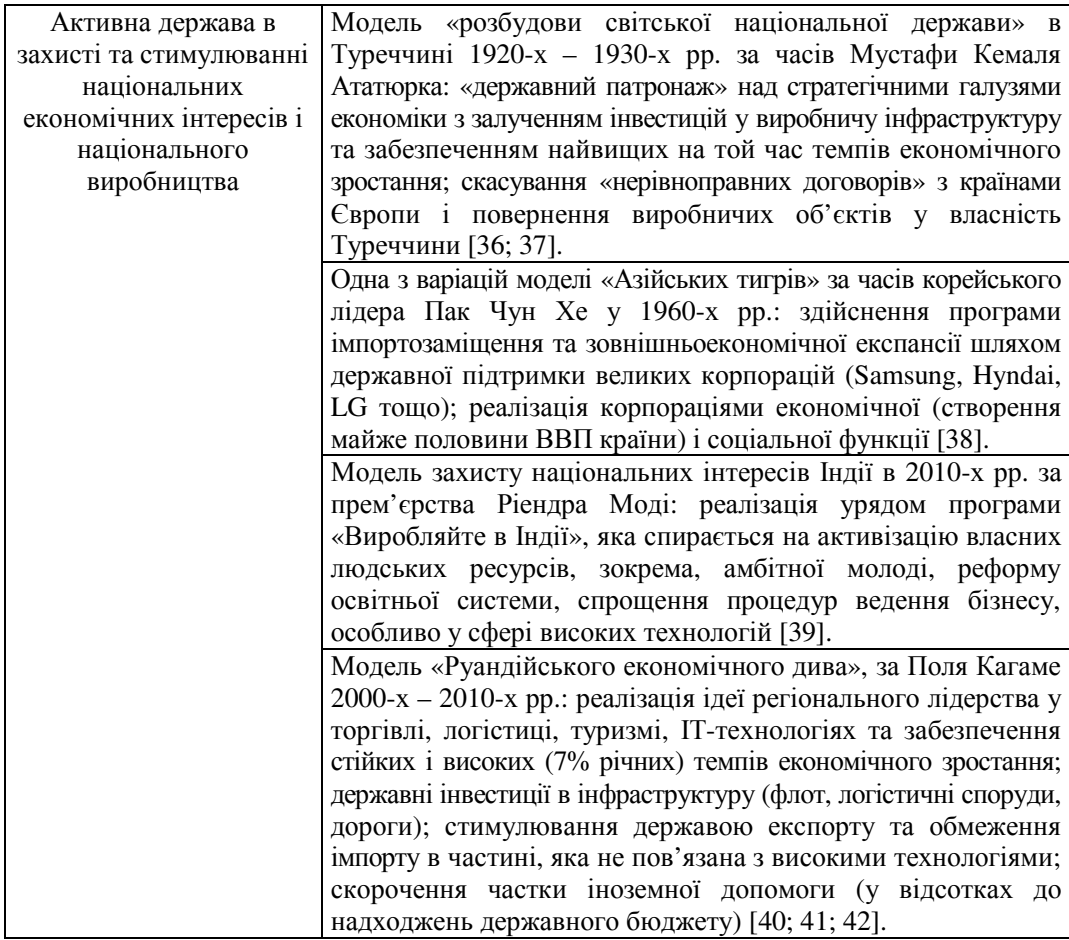

Джерело: створено автором самостійно.

Перелік успішних моделей публічного управління зі складниками ідеями, інструментами, організаційними практиками, - які відповідають концепції економічного націоналізму, міг би бути продовженим, а аналіз - поглибленим. У контексті теми нашого дослідження важливо те, що ці численні факти дійсно існують і що вони стосуються успішних країн. Термін «успішна країна» означає досягнення бажаного результату соціально-економічного розвитку. Це має інтерпретуватися як те, що концепція економічного націоналізму сприяє обмеженню невизначеності саме за критерієм отриманого результату.

\section{Висновки:}

Власне поняття «економіка невизначеності» віддзеркалює факт об'єктивного існування відносин 3 особливими характеристиками. Останні ідентифікуються та якісно оцінюються «економічною теорією невизначеності» - особливим напрямком досліджень в економічній науці. Остільки економічну невизначеність посилює або, навпаки, нівелює 
економічна політика, оскільки стає доцільним виокремлення поняття «економічна невизначеність, спричинена політикою». Економічну невизначеність спричиняє політика з ознаками невизначеності, або «політична невизначеність». Усвідомлення зв'язків між економічною та політичною невизначеністю створює підгрунтя для висновків у царині концепцій та моделей публічного управління.

Ідентифікація економіки невизначеності передбачає використання параметрів для її якісного визначення та оцінювання. 3 цією метою, на наш погляд, можуть використовуватися такі параметри, як волатильність економіки, раціональність очікувань економічних суб'єктів, конкурентність середовища, релевантність економічної політики та рівень іiі інституціоналізації.

У кількісному оцінюванні масштабів економіки невизначеності можуть використовуватися бази порівняльних даних, створених для розрахунку інтегральних індексів міжнародних організацій. Ідеться, зокрема, про субіндекси Індексу економічної свободи та Індексу глобальної конкурентоспроможності. Базою для оцінювання мають також ставати дані національної статистики щодо економічного зростання, коливання рівня цін та зайнятості, фондових індексів тощо.

В якості ймовірного адекватного способу реагування теорії і практики публічного управління на збільшення масштабів економіки невизначеності може розглядатися імплементація безпекового параметра в координати й цілі економічної політики. При цьому безпековий параметр має інтерпретуватися як обмеження економічної невизначеності.

В економічній теорії та в теорії публічного управління вже створені концепції й відповідні ідеї, які, у випадку практичної реалізації, можуть забезпечувати адекватне реагування на розширення масштабів економіки невизначеності. Це, по-перше, концепція публічного врядування 3 ідеєю розширення змістів управління за рахунок «третього сектору» та участі суспільства в реалізації «циклу економічної політики» (Governance). По-друге, це концепція економічного націоналізму з ідеями активної держави у захисті національних економічних інтересів, у створенні суспільних інститутів розвитку національних продуктивних сил і подолання економічного відставання.

Актуальними напрямками майбутніх досліджень у царині економіки невизначеності можуть стати: подальше уточнення множинних сенсів економіки невизначеності, ідентифікація та класифікація форм іiї прояву, вдосконалення інструментарію для оцінювання їі масштабів, узагальнення щодо нових способів реагування на економічну невизначеність у різних національних моделях публічного управління.

\section{Jimepamypa:}

1. Pettinger T. Economic uncertainty. Economics Help. URL : www.economicshelp.org. 
2. Jackson L., Kliesen K., Owyang M. The Nonlinear Effects of Uncertainty Shocks. Federal reserve bank of st. Louis.

3. Research Division P.O. Box 442 St. Louis, MO 63166. Working Paper 2018-035B. url : https://doi.org/10.20955/wp.2018.035.

4. Robert Lensink, Hong Bo., Elmer Sterken Does uncertainty affect economic growth? An empirical analysis Faculty of Economics University of Groningen, Netherlands. URL : https://link.springer.com/ content/pdf/10.1007/BF02707331.pdf.

5. Yonghong JIANG Y., Juan MENG J., NIE H. Visiting the economic policy uncertainty shocks - economic growth relationship: waveletbased granger-causality in quantiles approach. Romanian Journal of Economic Forecasting - XXI. 2018. №(2). P. 80-94. URL : http://www.rjef. ro/rjef/rjef2_18/rjef2_2018p80-94.pdf.

6. Baker S., Bloom N., Davis S. Measuring economic policy uncertainty. National Bureau of Economic Research. Working Paper. 2015. №21633. URL : http://www.nber.org/papers/w21633.

7. Moran M., Liu B. The vix index and volatility-based global indexes and trading instruments. CFA Institute Research Foundation. 2020. URL : https://papers.ssrn.com/sol3/papers.cfm?abstract_id=3668983.

8. Sargent T., Walles N. Rational expectations and the theory of economic policy. Journal of Monetary Economics. 1976. №2. P. 169-183. URL : https://EconPapers.repec.org/RePEc:eee:moneco:v:2:y:1976:i:2:p:169-183.

9. Taylor J. How the Rational Expectations Revolution Has Changed Macroeconomic Policy Research. 1999. Stanford university. Revised Draft: February 29. 2000. URL : https://web.stanford.edu/ johntayl/Papers/IEA Lecture.pdf.

10. Ватаманюк О. 3. Бізнес-економіка. Львів : ЛНУ імені Івана Франка, 2018. 324 с.

11. Elliott G., Caltech I., Timmermann A. Estimation and Testing of Forecast Rationality under Flexible Loss. Review of Economic. 2005. №72. P. 1107-1125: https://rady.ucsd.edu/faculty/directory/timmermann/pub/docs /forecast-rationality.pdf

12. The fraser institute: annual report «economic freedom of the world». URL : https://ueff.org/en/indices/78-the-heritage-foundation-the-indexof-economic-freedom.

13. Draft Policy Framework on Sound Public Governance. Preliminary version. OECD. 2018. P. 77.

14. Van der Meer F-B New Public Management and Evaluation. In book: New Public Management in Europe. 2007. P. 165-180.

15. Digiwhist - Erca. URL : www.againstcorruption.eu > digiwhist.

16. Keman H. Institutionalization social process. Article: institutionalization Definition, Sociology, \& Theories. Britannica. URL : www.britannica.com > topic > institutionaliz... 
17. Choi H. Institutionalization of Trust as Response to Globalization: The Case of Consumer Cooperatives in South Korea. Transition Studies Review. 2009. Vol. 16. P. 450-461.

18. The Global Competitiveness Report 2019. World Economic Forum. URL : http://www3.weforum.org/docs/WEF_TheGlobalCompetitivenessReport 2019.pdf.

19. GCI 4.0: Pillar 1: Institutions. URL : https://tcdata360.worldbank. org/indicators/h2bc5566c.

20. Kliesen L. Uncertainty and the Economy. Monday, April 1, 2013.

21. Altig D., Scott B., Barrero J. M., Bloom N., Bunn P., Chen S., Davis S. J., Meyer B., Mihaylov E., Mizen P., Parker N., Renault T., Smietanka P. and Thwaites G. Economic Uncertainty Before and During the COVID-19 Pandemic. Bank of England Staff Working Paper. 2020. №876. URL : https://voxeu.org/article/economic-uncertainty-wake-covid-19-pandemic.

22. Real-time economic analysis of the COVID-19 crisis: Lessons from Finland Helsinki Graduate School of Economics Situation. Room 21. May 2020. URL : https://voxeu.org/article/real-time-economic-analysis-covid19-crisis-lessons-finland\#sitcom.

23. Stolper W., Arbor A. A. Method of Constructing Community Indifference Curves. URL : http://www.sjes.ch/papers/1950-II-4.pdf.

24. Report from the commission on european governance. Luxembourg: Office for Official Publications of the European Communities. 2003. URL : https://ec.europa.eu/governance/docs/comm_rapport_en.pdf.

25. Rhodes R. The New Governance: Governing without Government. Politico1 Stiidia. 1996. XLIV. P. 652-667. URL : http://spp.xmu.edu.cn/wpcontent/uploads/2013/12/The-New-Governance-Governing-withoutGovernment-pdf.pdf.

26. Kohler-koch B., Rittberger B. Governance Turn' in EU Studies. JCMS. 2006. Vol. 44. P. 27-49. URL : https://ceses.cuni.cz/CESES-136version1-4C_Governance_turn_EU_kohler_rittberger_2006.pdf.

27. Klijn E., Koppenjan J. Governance Network Theory: Past, Present and Future. Policy and Politics. Vol 40(4). P. 187-206. URL : https://www.researchgate.net/publication/272138186_Governance_Network_ Theory_Past_Present_and_Future.

28. Lee M. Conceptualizing the New Governance: A New Institution of Social Coordination. Presented at the Institutional Analysis and Development Mini-Conference. 2003. May 3rd and 5th. URL : http://citeseerx.ist.psu.edu/viewdoc/download?doi=10.1.1.202.1474\&rep=re p1\&type $=$ pdf.

29. Saxena K. B. Ch. Towards excellence in e-governance. International Journal of Public Sector Management. №18(6). P. 498-513. URL : https://www.researchgate.net/publication/235271643_Towards_ excellence _in_e-governance. 
30. Політична економія суспільного прогресу Всеволода Голубничого. Вибрані праці. Відповідальний редактор д.е.н., професор Н. А. Супрун. Київ : Наукова думка, 2019. Том 2. С. 109-121.

31. Злупко С. М. Історія економічної теорії. Київ : «Знання», 2005. 719 c. C. $354-372$.

32. Панченко В. Економічна стратегія ОУН 1920 - 1950-ті рр.: розробка та реалізація. Інститут української археографії та джерелознавства НАН України. Київ, 2011. С. 6-12.

33. Економічний націоналізм та соціальна справедливість: збірник матеріалів / Упор. Т. Бойко, Ю. Сиротюк, Б. Галайко, К. Денисов. К. : НАЦ «УССД», «Видавець Олег Філюк», 2019. 320 с.

34. Sacks A. Why the Early German Socialists Opposed the World's First Modern Welfare State. 2019. URL : https:www.jacobinmag.com/2019/ 12/otto-von-bismarck-germany-social-democratic-party-spd.

35. Sagers J. H. Confucian Capitalism: Shibusawa Eiichi, Business Ethics, and Economic Development in Meiji Japan. The Quarterly Journal of Austrian Economics. 2019. Vol. 22. No. 1. P. 91-99. URL : https://mises.org/library/confucian-capitalism-shibusawa-eiichi-businessethics-and-economic-development-meiji-japan.

36. Brouard S., Mazur A. The French Fifth Republic at Fifty: Beyond Stereotypes. 2009. URL : https://www.researchgate.net/publication/ 302014813_The_French_Fifth_Republic_at_Fifty_Beyond_Stereotypes.

37. Berk Nation-Building, Party-Strength, and Regime Consolidation: Kemalism in Comparative Perspective. Turkish Studies. №15:4. 2014. P. 600-620. URL : https://www.tandfonline.com/doi/full/10.1080/14683849.2014. 986318? scrol l=top\&needAccess $=$ true.

38. Glyptis A-L Kemalism as a Language for Turkish Politics: Cultivation, Reproduction. Negotiation. URL : http://etheses.lse.ac.uk/423/1/ Glyptis_Kemalism\%20as\%20a\%20language\%20for\%20Turkish\%20politics.pdf.

39. Haggard St., Byung-Kook Kimand, Chung-in Moon. The Transitionto Export-Led Growthin South Korea: 1954-1966. The Journal of Asian Studies. 1990. URL : https://www.researchgate.net/publication/ 23723634_The_Transition_to_Export-led_Growth_in_South_Korea_1954-1966.

40. Maiorano D., Torri T. India 2014: the annihilation of the congress party and the beginning of the Modi era Home. The Journal Asia Maior. Vol. XXV. 2014. URL : https://www.asiamaior.org/the-journal/07asia-maior-vol-xxv-2014.

41. Davis K. Paul Kagame and Rwanda: an economic model for Africa. Ventures for Africa. June 15. 2014. URL : http://venturesafrica.com/ blog/2014/06/15/paul-kagame-and-rwanda-an-economic-model-for-africa/.

42. Country Profile - Rwanda by the Economic Commission for Africa. Publications Section. Economic Commission for Africa. URL : https://www.uneca.org/sites/default/files/images/ORIA/CP/rwanda.pdf. 


\title{
ФОРСАЙТ У ПУБЛІЧНОМУ УПРАВЛІННІ ЯК ІНСТРУМЕНТ РЕГУЛЮВАННЯ ЗА УМОВ ЕКОНОМІЧНОЇ НЕВИЗНАЧЕНОСТІ
}

\author{
Смельяненко Лариса Михайлівна, \\ доктор економічних наук, професор, \\ ДВНЗ «Київський начіональний університет імені Вадима Гетьмана», \\ ORCID: https://orcid.org/0000-0002-6611-5228,

\section{Захарова Ксенія Федорівна,} \\ кандидат економічних наук, \\ дочент кафедри теоретичної та прикладної економіки, \\ ВНЗ Університет економіки та права «КРОК», \\ ORCID: https://orcid.org/0000-0002-9024-5321
}

Анотація. Розділ присвячено науковій та прикладній проблемі управління економічною невизначеністю з використанням форсайта. Останній дає можливість формувати образ майбутнього та творити його вже сьогодні. Для відповіді на питання про те, у який спосіб форсайт стає інструментом публічного управління економічною невизначеністю, досліджено сучасне тлумачення його змісту. Проаналізовано приклади використання форсайта та методи, які при цьому застосовувалися у практиці різних країн. Визначено етапи становлення форсайта. На основі аналізу вже існуючого досвіду українських форсайт-проєктів зроблено узагальнення щодо особливостей українського форсайта, доцільних напрямків його застосування та розвитку. Розглянуто варіант застосування форсайта для запобігання створенню непривабливого образу українського майбутнього, зокрема через згортання ринкової конкуренції..

Ключові слова: публічне управління, форсайт, методи форсайта, форсайт-проєктування.

Невизначеність сучасної української економіки посилюється на тлі невирішених внутрішніх політичних і соціоекономічних конфліктів, зростання рівня тінізації, незавершеності реформ тощо. До цього переліку додаються такі зовнішні чинники, як рецесії, що охоплюють більшість країн світу, імпульси від неочікуваних катастрофічних подій, що даються взнаки для всього світу. Тому в публічному управлінні національною економікою посилюється потреба більш досконалого передбачення. Реакцією науки та управлінської практики на таку потребу став інструментарій форсайта. Більш досконалим, ніж існуючі інструменти, форсайт $є$ тому, що він створює можливість не лише прогнозувати майбутнє, а й моделювати його. Останнє $є$ 
особливо важливим для публічного управління остільки, оскільки робить його інструментом обмеження економічної невизначеності майбутнього.

Метою цього розділу є визначення можливостей форсайта як інструменту стратегічних рішень у публічному управлінні, з огляду на необхідність обмеження невизначеності національної економіки.

Інструментарій форсайта впевнено увійшов в управлінську теорію та практику. Але питання про його визначеність, складники, способи й форми застосування продовжують бути предметом дискусій. Ми акцентуємо увагу на тих моментах сучасного тлумачення форсайта, які $€$ принципово важливими, з огляду на можливість його використання для управління економічною невизначеністю.

Через необхідність використання англійського терміна «форсайт» (foresight), заради більш точної ідентифікації змістів, доцільно віднайти український відповідник. Таким доцільним терміном-відповідником до англійського «форсайт», на наш погляд, є «моделювання майбутнього». Зрозуміло, що в конкретному контексті йтиметься про майбутнє певної сфери. У нашому випадку, це - національна економіка, яка стає об'єктом публічного управління.

Зміст форсайта найкраще розкривається при його порівнянні (протиставленні - vs) з іншими способами передбачення. Нам видаються доцільними такі порівняння:

- формування сценаріїв майбутнього vs визначення трендів, закладених у минулому;

- стратегічне (на довгий період) планування подій vs перманентне реагування на поточні (у близькому майбутньому) події;

- усвідомлення пріоритетів розвитку vs оцінювання результатів критичних ситуацій, що вже сталися;

- інноваційні рішення, орієнтовані на віддалені наслідки, vs традииійні рішення, орієнтовані на близькі наслідки;

- випередження (запобігання) подій vs реагування після подій (перебування в їхньому фарватері).

За наведеними протиставленнями, форсайт є таким інструментом моделювання майбутнього, який забезпечує розвиток за певним сиенарієм, формування стратегій на підставі усвідомлення пріоритетів, інноваційність управлінських рішень, які дозволяють випереджати (запобігати) події.

У серії робіт авторитетних дослідників знаходимо підтвердження обгрунтованості виокремлених нами ознак форсайта.

За визначенням провідного ідеолога форсайта Б. Мартіна, форсайт - це технологія, пов'язана з постійним намаганням заглянути у віддалене майбутне науки, технологій, економіки і суспільства. Цей 
погляд у майбутнє має на меті побачити стратегічно важливі сфери наукових досліджень та нові технології, які забезпечать найбільші економічні й соціальні вигоди [1].

Французький професор економіки Ж. Хероуд і німецький економіст К. Кульс трактують форсайт як процес усвідомлення трендів тривалої перспективи на засадах системного підходу [2].

Дослідник європейської економіки П. Беккер тлумачить форсайт як процес активного пізнання майбутнього у середньостроковій i довгостроковій перспективі з метою усвідомлення майбутнього науки, економіки та суспільства, а також для мобілізації спільних зусиль [3].

Дослідник з Великої Британії Л. Гохберг акцентує увагу на тому, що форсайт - це система методів експертної оцінки довгострокових перспектив інноваційного розвитку, технологічних проривів, які можуть впливати на економіку та суспільство [4].

В одному 3 найбільш цитованих досліджень про форсайт, він визначається як процес систематичного збирання інформації про майбутнє та розробки середньо- і довгострокових візій майбутнього для рішень та спільних дій у реальному часі [5]. Такі рішення й пов'язані з ними дії дістали назву «форсайт-проєкти». Особливість останніх полягає у тому, що вони поєднують два типи проєктів: дослідницьких робіт і сучасних практичних дій 3 орієнтацією на отримання віддалених у часі результатів.

У фундаментальному дослідженні міжнародної організації UNIDO (United Nations Industrial Development Organization) форсайт визначається як систематичне передбачення довгострокового майбутнього науки, технології, економіки і суспільства для ідентифікації тих сфер стратегічних досліджень та тих технологій, які забезпечуватимуть найбільші економічні й соціальні вигоди суспільства [6].

Найавторитетніша міжнародна організація форсайта - Foresight group - у своїй діяльності спирається на ідею про обмеженість традиційних статистичних прогнозів та необхідність розширення кола досліджуваної інформації про суспільство для успішного прийняття рішень. Так званий «трикутник векторів форсайта» - обмірковування майбутнього, обговорення майбутнього та окреслення майбутнього обгрунтований дослідниками цієї міжнародної організації, став класикою науки про форсайт [7].

Розвиток ідеї «трикутника векторів форсайта» передбачає розкриття змісту цих векторів (рис. 1). Зокрема, таке пояснення змісту міститься в матеріалах, створених під егідою Європейської Комісії (CORDIS - Community Research \& Development Information Service). 


\section{Концептуальне бачення форсайта CORDIS}

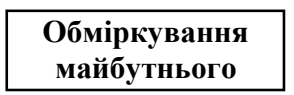

\begin{tabular}{|c|}
\hline Прогнозування, \\
оцінка технологій \\
дослідження \\
майбутнього та інші \\
форми форсайту - \\
це спроба визначити \\
довготривалі тренди \\
і скоригувати \\
прийняття \\
управлінських \\
рішень
\end{tabular}

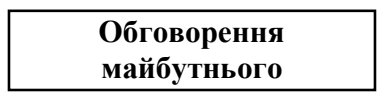

Форсайт - процес, який

зацікавлює всіх

стейкхолдерів: дослідні центри, неурядові фонди, громадські організації, промисловість та ін. Відкрита дискусія між учасниками ведеться на майданчиках різного типу, як правило, у формі експертної дискусії

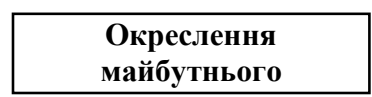

\begin{tabular}{|c|}
\hline Визначення можливостей \\
майбутнього, створення \\
бажаного образу \\
майбутнього і визначення \\
стратегій його досягнення. \\
Результати досліджень \\
залучаються до \\
суспільного прийняття \\
рішень та забезпечують й \\
покращують відповідні \\
стратегії \\
\hline
\end{tabular}

\section{Рис. 1. Зміст «сторін трикутника векторів форсайта»} Джерело: [8].

На наш погляд, для успішного застосування форсайта важливо акцентувати увагу саме на процесуальному підході до тлумачення його змісту. За такого підходу, форсайт постає як система усталених алгоритмів, процедур і норм нагромадження та аналізу інформації про зміни. Це дає можливість суспільству в особі органів управління, професійних й інших спільнот передбачити та ніби «випереджати» майбутнє. Таке випередження означає: діяти з урахуванням інноваційних трендів, які лишень формуються, спиратися у діяльності на обгрунтовані альтернативні сценарії розвитку подій.

Попри відмінності акцентів у наведених нами визначеннях форсайта, в них є дещо принципово спільне. Це - визнання того, що формування «бажаного» майбутнього залежить від дій сьогодні. Тому методологічно важливими для застосування форсайта $\epsilon$ такі його засадничі ідеї:

- майбутнє твориться сьогодні;

- майбутнє є варіативним: обраний варіант дій для сьогодні визначає результат майбутнього;

- майбутнє не стільки прогнозується, скільки проєктується;

- учасники форсайта свідомо обирають майбутнє та управляють процесами змін.

Форсайт, як управлінський феномен, пройшов певні етапи свого становлення. Дослідження цих етапів має і теоретичне, і прикладне значення. Основні етапи становлення форсайта подано в аналітичній табл. 1. 
Таблиия 1

Етапи еволюції форсайта

\begin{tabular}{|c|c|c|c|}
\hline $\begin{array}{l}\text { Межi } \\
\text { етапу }\end{array}$ & $\begin{array}{c}\text { Пропонована } \\
\text { назва етапу }\end{array}$ & Сфера застосування & $\begin{array}{c}\text { Країни, які системно } \\
\text { застосовують форсайт }\end{array}$ \\
\hline $\begin{array}{l}\text { І етап - } \\
\text { 1960-ті - } \\
\text { 1980-ті pp. }\end{array}$ & Технологічний & $\begin{array}{l}\text { Технологічні та } \\
\text { оборонні дослідження, } \\
\text { обгрунтування } \\
\text { інноваційної політики } \\
\text { урядів, проєкти } \\
\text { окремих фірм }\end{array}$ & $\begin{array}{l}\text { CША (корпорація } \\
\text { RAND), Японія }\end{array}$ \\
\hline $\begin{array}{l}\text { II етап - } \\
\text { 1980-ті - } \\
\text { 2000-ні рр. }\end{array}$ & $\begin{array}{l}\text { Ринково- } \\
\text { орієнтований }\end{array}$ & $\begin{array}{l}\text { Оцінка соціальних } \\
\text { наслідків упровадження } \\
\text { нових технологій }\end{array}$ & $\begin{array}{l}\text { США, Велика Британія, } \\
\text { Німеччина, Фінляндія, } \\
\text { Австралія, Нідерланди, } \\
\text { Нова Зеландія, Японія }\end{array}$ \\
\hline $\begin{array}{l}\text { III етап - } \\
2000-\text { ні - } \\
2020 \text { рр. }\end{array}$ & $\begin{array}{l}\text { Соціально- } \\
\text { економічний }\end{array}$ & $\begin{array}{l}\text { Охорона здоров’я, } \\
\text { освіта, якість життя, } \\
\text { національна безпека, } \\
\text { екологія, міжнародна } \\
\text { політика, торгівля, } \\
\text { економіка }\end{array}$ & $\begin{array}{l}\text { Понад } 30 \text { країн, } \\
\text { включно з розвиненими } \\
\text { та тими, що } \\
\text { розвиваються }\end{array}$ \\
\hline
\end{tabular}

Джерело: складено автором на основі [9-13].

Як свідчить інформація, подана в аналітичній табл. 1, форсайт пройшов принаймні три етапи еволюції. Його становлення розпочиналося 3 епізодичного застосування в технологічній сфері двох найбільш розвинених країн у 1960-х рр. - США та Японії. На початку 2020-х рр. форсайт застосовується не лише у проєктуванні сфери високих технологій, а й у багатьох інших сферах. Кількість країн застосування форсайта, як інструменту управління на засадах моделювання майбутнього, зростає за рахунок і розвинених країн, і країн, що розвиваються.

Окремі етапи еволюції форсайта мають такі визначальні ознаки та особливості.

На першому етапі - технологічного форсайта - здійснювалося оцінювання потенціалу науки і технологій для забезпечення кращих конкурентних позицій країн, регіонів, компаній. Використовувалися техніки економічного планування на основі лінійної моделі інновацій. Коло учасників дослідження обмежувалося експертами в галузі науки і технологій. Технологічна сфера розглядалася автономно від соціальної та культурної.

На другому етапі - ринково-орієнтованого форсайта акцентувалися потреби кращої організації ринків та окремих видів підприємництва. Передбачалися ринкові наслідки впровадження нових технологій. Уперше технологічні прогнози почали розглядатися в контексті вирішення гуманітарних проблем: голоду, бідності, безпеки 
тощо. В якості експертів почали залучатися представники бізнесу й органів державної влади.

На третьому етапі - соиіально-економічного форсайта - в центр уваги потрапляють соціальні питання та невирішені проблеми суспільства. Тому йдеться про аналіз зв'язків між новими технологіями, організацією ринків, з одного боку, та життям суспільства - 3 іншого. Така зміна акцентів відбилася на складі груп експертів. До них почали залучати не лише представників наукового та підприємницького середовища, а й політиків, державних чиновників, активістів громадянського суспільства, діячів місцевого самоврядування. Відбулося усвідомлення важливості для моделювання майбутнього комунікацій між владою та громадянами, між різними суспільними верствами. Майбутнє постало як те, що грунтується на погодженні інтересів, вирішенні конфліктів і знаходженні консенсусу.

У контексті досліджуваної у цьому розділі проблеми використання форсайта для обмеження економічної невизначеності важливо ідентифікувати та класифікувати прийоми й методи, якими послуговуються організатори форсайт-проєктів.

Форсайт, як особливий управлінський інструмент, передбачає використання таких прийомів:

- Переважного орієнтування на так звані «слабкі» маркери майбутніх змін.

Зазвичай у складі маркерів змін розрізняють «сильні», які свідчать про очевидне настання подій у недалекій перспективі, та «слабкі». Через «слабкі» маркери виявляється віддалене майбутнє, обриси якого не стали очевидними. Форсайт грунтується на «слабких» маркерах. Це дає можливість, з певною ймовірністю, передбачати віддалені, неочевидні зміни, що вимагають концептуально нових, стратегічних управлінських рішень;

- Ідентифікації в якості об'єктів дослідження складних взаємодій та великих баз даних, за вимогами так званого підходу «нарощування» («bottom-up approach»).

Для передбачення майбутнього може використовуватися інформація з обмеженого кола джерел при абстрагуванні від складних взаємозв' язків. Таким є підхід «спрощенння» («top-down approach»). Форсайт грунтується на дослідженні максимально можливого кола джерел, а також складних взаємодій між різними сферами;

- Участі у моделюванні майбутнього груп осіб - так званих стейкхолдерів змін - з різною імплементованістю у власне процес змін.

Для моделювання майбутнього необхідно враховувати різні візії творців цього майбутнього. Активність творення майбутнього визначається участю у змінах за поточний період. Носіями змін стають групи людей, які неоднаково залучені власне до процесу змін. Перша 
група - «ініціатори» - безпосередньо зацікавлена в організації та виконанні всіх запланованих дій. Друга група - «основні учасники» об'єктивно долучається до розпочатих змін, за логікою їх здійснення. Третя група - «опосередковані учасники» - гіпотетично може впливати на зміни або долучатися до них через інших осіб;

- Перманентного вдосконалення моделі майбутнього в процесі практичної реалізації форсайта.

«Наближення майбутнього» потребує постійного внесення уточнень у форсайт-проєкти. Форсайт не завершується як явище. Може йтися лише про завершення окремого етапу форсайт-проєкту. Як постійний процес, форсайт може успішно здійснюватися лише в розвиненому громадянському суспільстві. Саме громадянське суспільство забезпечує те, що майбутнє стає не лише продуктом діяльності вчених та винахідників, але й результатом активності громад і громадян.

Інструментарій форсайта охоплює складну сукупність методів. Ідеться, приблизно, про пів сотні методів з різних сфер знань. Це, до прикладу, такі сфери, як економетрика та статистика, економіка та управління, соціологія та психологія тощо. Використовується навіть аналіз на основі художнього осмислення майбутнього у творах наукової фантастики тощо.

Найбільш досконала візуалізація методів форсайта здійснена через так званий «діамант Поппера». У ньому віддзеркалено класифікацію методів форсайта за критерієм джерела знання. Використано ідею про існування чотирьох джерел знання, а саме:

- творчості з методами, що спираються на когнітивні та креативні здібності учасників управління змінами;

- експертизи з відповідними методами експертного оцінювання з боку фахівців певних сфер, що мають знання, досвід та інтуїцію;

- доказовості, яка передбачає використання методів наукового аналізу даних і фактів;

-взаємодіï, яка реалізується при застосуванні методів ідентифікації колективного (спільного) бачення перспектив майбутнього та перебігу подій.

Методи форсайта, за «діамантом Поппера», подано на рис. 2.

Ілюстрований на рис. 2 «діамант форсайта» охоплює більше 30 методів дослідження та моделювання майбутнього. 3 огляду на їх зміст, вони можуть бути умовно розподілені на чотири групи, а саме: творчості, експертизи, взаємодії та доказовості.

Зрозуміло, що всі зазначені методи не можуть застосовуватися в кожному з форсайт-проєктів. На відбір методів у кожному конкретному випадку впливатиме природа досліджуваної предметної області, наявні ресурси для дослідження, кваліфікація та зацікавленість учасників дослідження й моделювання майбутнього тощо. 


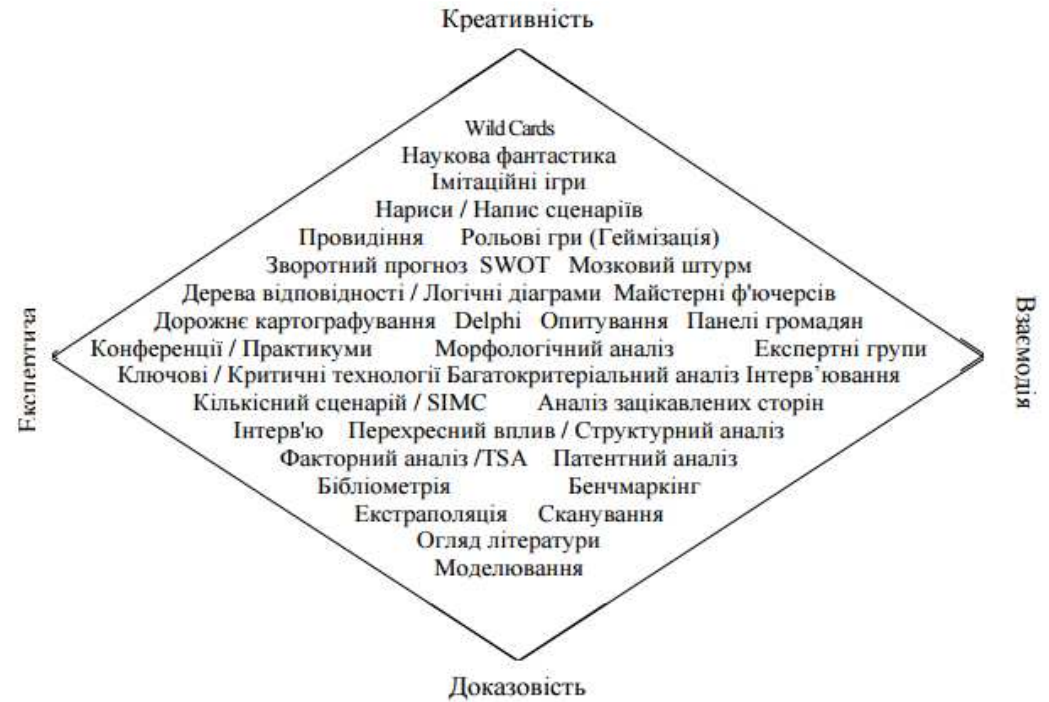

Джерело: [14].

Рис. 2. «Діамант форсайта» Р. Попера

Аналіз практики застосування форсайта дає підстави для визначення таких сучасних тенденцій:

- арсенал методів форсайта постійно розширюється;

- в окремі періоди визнаються більш доцільними й тому починають застосовуватися більш активно певні методи;

- в окремих країнах надаються переваги певним наборам методів форсайта.

На підтвердження визначених тенденцій скористаємося такими фактами:

Перший. Сучасні методи якісного та кількісного аналізу, які використовуються у форсайт-проєктах, охоплюють те, що раніше не складало арсенал форсайта. Зокрема, поширеними методами якісного аналізу сьогодні стали: системні огляди наукової і науково-фантастичної літератури, морфологічний аналіз, так звані «дерева відповідностей», сценарні та рольові ігри тощо. Методи кількісного аналізу охоплюють: аналіз взаємного впливу - cross-impact analysis, багатокритеріальний (кластерний) аналіз, конструювання індексів інтегрального оцінювання тощо. Визнано, що попри розширення арсеналу методів, у кожному конкретному періоді найбільш активно використовуються лише 10-15 3 них.

Другий. Зафіксовано такі приклади пріоритетів країн у використанні методів форсайта. В Японії при проведенні науково- 
технологічного форсайта переважно застосовувався метод Делфі. У Великій Британії і Німеччині роблять акцент на комбінуванні різних методів. У США та Франції надається перевага методам обгрунтування переліків критично важливих технологій.

Третій. У Світовому огляді форсайт-методів [15] зазначено, що в більшості досліджених форсайт-проєктах лідируючу позицію посідають три методи: огляди літератури, експертні панелі й сценарне моделювання. Нечасто використовувалися ігрові сценарії, бібліометрія і багатокритеріальний аналіз. У форсайт-проєктах почастішали приклади залучення різних представників публічно-приватного партнерства, громадянського суспільства, людей з різних суспільних прошарків. Це дозволяє посилити ефект взаємодії.

Підхід до форсайта як до перманентно повторюваного процесу дає підстави для виокремлення закономірних етапів реалізаиії. Один із варіантів такого розмежування етапів реалізації ілюстровано на рис. 3 .

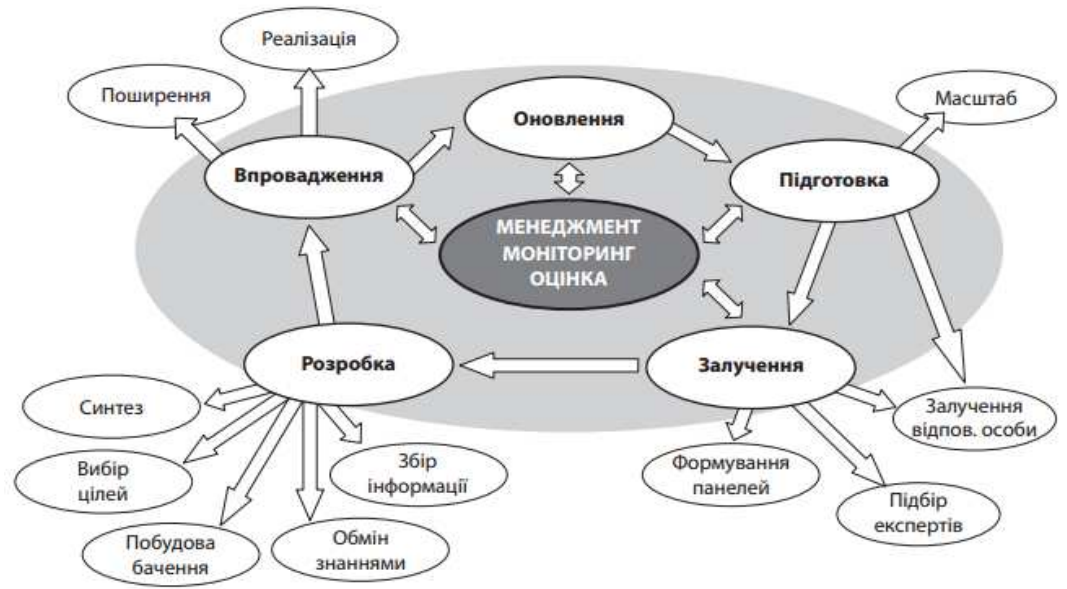

Джерело: [16].

\section{Рис. 3. Організація процесу форсайта}

Репрезентований на рис. 3 підхід передбачає виокремлення таких етапів у реалізації форсайта, як підготовка, залучення учасників; розробка; впровадження; оновлення (у сенсі коригування). Кожний з п'ятьох етапів передбачає серію конкретних дій з реалізації форсайта.

Оскільки форсайт має достатньо тривалу історію, починаючи 3 середини XX ст., то вже зараз можна робити узагальнення і щодо загальних підходів, i щодо особливостей його організації в різних країнах.

Перше узагальнення про особливості організації форсайта стосується його інституиійного забезпечення. Воно зазвичай здійснюється національними організаціями форсайта та в межах національних 
цільових програм. Зокрема, такі національні організаційні структури для реалізації форсайта створено у країнах ОЕСР. Інформацію про це подано в аналітичній табл. 2.

Таблиия 2

Інститути забезпечення форсайта в окремих країнах

\begin{tabular}{|l|l|}
\hline \multicolumn{1}{|c|}{ Країна } & \multicolumn{1}{|c|}{ Назва організації / програми з форсайта } \\
\hline Австрія & Institute of Technology Assessment Delphy and 2013 Report \\
\hline Бельгія & Foresight at Federal level \\
\hline Болгарія & Applied Research and Communications Fund \\
\hline $\begin{array}{l}\text { Велика } \\
\text { Британія }\end{array}$ & The Foresight initiative \\
\hline Греція & The Greek Foresight Programme \\
\hline Естонія & Institute for Baltic Studies \\
\hline Iрландія & Irish Council for Science, Technology and Innovation \\
\hline Iспанія & Observatorio de Prospectiva Tecnologica Industrial (OPTI) \\
\hline Iталія & Fondazione Rosselli \\
\hline Кіпр & The Agricultural Research Institute \\
\hline Мальта & Malta Council for Science and Technology \\
\hline Нідерланди & $\begin{array}{l}\text { Consultative Committee of Sector Councils for R\&D Royal } \\
\text { Netherlands Academy of Arts and Science for research foresight }\end{array}$ \\
\hline Німеччина & The FUTUR initiative \\
\hline Норвегія & Norway 2030 \\
\hline Польща & $\begin{array}{l}\text { KBN, of the Ministry of Scientific Research and Information } \\
\text { Technology }\end{array}$ \\
\hline Португалія & Engineering and Technology 2000 \\
\hline Угорщина & National Office of Research and Technology \\
\hline Фінляндія & Ministry of Trade and Industry FinnSight 2015 \\
\hline Франція & Technologies-cles 2005 \\
\hline Чехія & Technology center of Academy of Sciences \\
\hline Швеція & Teknisk Framsyn for Sverige \\
\hline
\end{tabular}

Джерело: складено авторами на основі [17-20].

Інформація, подана в табл. 2, ілюструє факт існування у країнах ОЕСР спеціальних національних центрів і програм, які забезпечують форсайт-дослідження. Вони формують підгрунтя для прийняття управлінських рішень, розрахованих на тривалу перспективу.

Це втілюється у національних стратегіях розвитку та у формуванні поточної соціально-економічної політики, орієнтованої на майбутні зміни.

Друге узагальнення 3 досвіду організації форсайта стосується сфер його застосування, методів та отриманих результатів. Інформація про це подана в аналітичній табл. 3 . 


\section{Таблиия 3}

\section{Приклади форсайт-проєктів у країнах $з$ досвідом системних форсайт-досліджень}

\begin{tabular}{|c|c|c|c|c|c|}
\hline $\begin{array}{c}\text { Країна/ } \\
\text { період }\end{array}$ & $\begin{array}{c}\text { Мета } \\
\text { форсайт- } \\
\text { проєкту }\end{array}$ & $\begin{array}{l}\text { Часовий } \\
\text { горизонт }\end{array}$ & $\begin{array}{c}\text { Організаційні } \\
\text { форми }\end{array}$ & Методи & Результати \\
\hline $\begin{array}{l}\text { США } \\
\text { критичні } \\
\text { технології } \\
\text { з 1960-х } \\
\end{array}$ & $\begin{array}{l}\text { Визначення } \\
\text { пріоритетів } \\
\text { технологічного } \\
\text { розвитку }\end{array}$ & $\begin{array}{c}10 \\
\text { років }\end{array}$ & $\begin{array}{l}\text { Тематичні } \\
\text { панелі (групи) }\end{array}$ & $\begin{array}{l}\text { Опитування } \\
\text { експертів, } \\
\text { експертні } \\
\text { панелі }\end{array}$ & $\begin{array}{l}\text { Визначення } \\
\text { критично } \\
\text { важливих } \\
\text { технологій }\end{array}$ \\
\hline $\begin{array}{l}\text { Японія } \\
\text { технологіч- } \\
\text { ний форсайт } \\
\text { з 1960-х }\end{array}$ & $\begin{array}{l}\text { Окреслення } \\
\text { основних } \\
\text { проблем } \\
\text { технологічного } \\
\text { розвитку }\end{array}$ & $\begin{array}{c}30 \\
\text { років }\end{array}$ & $\begin{array}{l}\text { Експертні } \\
\text { панелі }\end{array}$ & $\begin{array}{l}\text { Делфі- } \\
\text { опитування, } \\
\text { бібліометрич- } \\
\text { ний аналіз, } \\
\text { експертні } \\
\text { панелі, } \\
\text { сценарії }\end{array}$ & $\begin{array}{l}\text { Рекомендації } \\
\text { щодо } \\
\text { напрямків } \\
\text { технологічного } \\
\text { розвитку та } \\
\text { наукової } \\
\text { політики }\end{array}$ \\
\hline $\begin{array}{l}\text { Велика } \\
\text { Британія } \\
\text { друга } \\
\text { половина } \\
\text { 1990-х рр. }\end{array}$ & $\begin{array}{l}\text { Підвищення } \\
\text { добробуту та } \\
\text { якості життя }\end{array}$ & $\begin{array}{l}10-20 \\
\text { років }\end{array}$ & $\begin{array}{l}16 \text { галузевих } \\
\text { панелей }\end{array}$ & $\begin{array}{l}\text { Делфі- } \\
\text { опитування, } \\
\text { експертні } \\
\text { панелі }\end{array}$ & \begin{tabular}{|l|}
360 \\
рекомендацій \\
щодо урядових \\
рішень
\end{tabular} \\
\hline $\begin{array}{l}\text { Велика } \\
\text { Британія } \\
\text { кінець } \\
1990-x \text { - } \\
\text { початок } \\
\text { 2000-х pp. }\end{array}$ & $\begin{array}{l}\text { Посилення } \\
\text { інноваційного } \\
\text { потенціалу } \\
\text { науки }\end{array}$ & $\begin{array}{l}10-20 \\
\text { років }\end{array}$ & $\begin{array}{l}11 \text { галузевих } \\
\text { та } 3 \text { тематичні } \\
\text { панелі }\end{array}$ & $\begin{array}{l}\text { Семінари, } \\
\text { відкриті } \\
\text { дискусії, } \\
\text { панелі, банк } \\
\text { знань } \\
\text { (інтернет- } \\
\text { платформа) }\end{array}$ & $\begin{array}{l}\text { Створення } \\
\text { тренінгових } \\
\text { центрів } \\
\text { форсайта, } \\
\text { підтримка } \\
\text { національної } \\
\text { інноваційної } \\
\text { системи }\end{array}$ \\
\hline $\begin{array}{l}\text { Велика } \\
\text { Британія } \\
\text { початок } \\
\text { 2000-х pp. }\end{array}$ & $\begin{array}{l}\text { Зростання } \\
\text { інноваційного } \\
\text { потенціалу } \\
\text { науки, } \\
\text { забезпечення } \\
\text { сталого } \\
\text { розвитку }\end{array}$ & $\begin{array}{l}10-20 \\
\text { років }\end{array}$ & $\begin{array}{l}\text { Комплексна } \\
\text { програма } 3 \\
\text { проєктів, які } \\
\text { виконуються } \\
\text { одночасно }\end{array}$ & $\begin{array}{l}\text { Групи } \\
\text { експертів, } \\
\text { сценарії, } \\
\text { сканування } \\
\text { технологій }\end{array}$ & $\begin{array}{l}\text { Концентрація } \\
\text { ресурсів на } \\
\text { практичному } \\
\text { використанні } \\
\text { наукових } \\
\text { результатів }\end{array}$ \\
\hline $\begin{array}{l}\text { Франція } \\
\text { початок } \\
\text { 2000-х рр. }\end{array}$ & $\begin{array}{l}\text { Визначення } \\
\text { критично } \\
\text { важливих } \\
\text { технологій та } \\
\text { конкурентних } \\
\text { переваг }\end{array}$ & $\begin{array}{c}5 \\
\text { років }\end{array}$ & $\begin{array}{l}\text { Тематичні } \\
\text { панелі для } \\
\text { обгрунтування } \\
\text { пріоритетних } \\
\text { технологій }\end{array}$ & $\begin{array}{l}\text { Експертна } \\
\text { оцінка за } \\
\text { критерієм } \\
\text { посилення } \\
\text { національної } \\
\text { конкуренто- } \\
\text { спроможності }\end{array}$ & $\begin{array}{l}\text { Перелік } 119 \\
\text { ключових } \\
\text { технологій } \\
\text { майбутнього }\end{array}$ \\
\hline $\begin{array}{l}\text { Німеччина } \\
\text { початок } \\
\text { 2000-х рр. }\end{array}$ & \begin{tabular}{|l} 
Розробка \\
стратегічного \\
бачення \\
розвитку для \\
Міністерства \\
освіти та \\
науки
\end{tabular} & $\begin{array}{c}20 \\
\text { років }\end{array}$ & $\begin{array}{l}\text { Групи оціню- } \\
\text { вання напрям- } \\
\text { ків науково- } \\
\text { технологічного } \\
\text { розвитку та } \\
\text { сфер } \\
\text { використання } \\
\text { технологій }\end{array}$ & $\begin{array}{l}\text { Семінари, } \\
\text { відкрита } \\
\text { дискусія, } \\
\text { експертні } \\
\text { панелі, } \\
\text { сценарії, } \\
\text { онлайн- } \\
\text { опитування }\end{array}$ & $\begin{array}{l}\text { Стратегічні } \\
\text { напрямки } \\
\text { розвитку, } \\
\text { пріоритети для } \\
\text { програм } \\
\text { майбутніх } \\
\text { досліджень }\end{array}$ \\
\hline
\end{tabular}


Продовження табл. 3

\begin{tabular}{|l|l|l|l|l|l|}
\hline Угорщина & $\begin{array}{l}\text { Визначення } \\
\text { початок } \\
\text { 2000-х pр. }\end{array}$ & $\begin{array}{l}15-20 \\
\text { текнологічних } \\
\text { пріоритетів, } \\
\text { напрямків } \\
\text { правового } \\
\text { регулювання } \\
\text { та державної } \\
\text { політики }\end{array}$ & $\begin{array}{l}\text { Тематичні } \\
\text { панелі }\end{array}$ & $\begin{array}{l}\text { Експертні } \\
\text { панелі }\end{array}$ & $\begin{array}{l}\text { Створення та } \\
\text { зміцнення } \\
\text { горизонтальних } \\
\text { взаємозв'язків } \\
\text { переліку наука- } \\
\text { освіта-бізнес }\end{array}$ \\
\hline
\end{tabular}

Джерело: складено авторами на основі [21-23].

Досвід п’ятьох країн, репрезентований у таблиці, свідчить про використання форсайта переважно для моделювання змін у науці, освіті, державній політиці для забезпечення технологічних проривів, обриси яких уже окреслювалися. Попри відмінності в окремих країнах, горизонт форсайта здебільшого складав 10-20 років. Відбувалося помітне урізноманітнення форм форсайта впродовж 1960-х - початку XXI ст. Результати форсайта втілювалися в обгрунтованих переліках перспективних напрямків технологічних змін, у стратегічних програмах національного розвитку.

Третє узагальнення стосується висновку про формування в країнах особливих моделей форсайта 3 власними національними акцентами. Відповідь на питання, чому країни, реалізуючи форсайтпроєкти, обирають ті, а не інші пріоритети, може ставати предметом спеціальних досліджень. Інформація про визначальні риси моделей форсайта в окремих країнах подано в аналітичній табл. 4.

Табличя 4

Особливості національних моделей форсайта в окремих країнах

\begin{tabular}{|l|l|}
\hline \multicolumn{1}{|c|}{ Країна } & \multicolumn{1}{|c|}{ Акценти та визначальні риси моделей форсайта } \\
\hline США & $\begin{array}{l}\text { - Корпоративний форсайт для окремих секторів, передусім енергетики } \\
\text { та сфери високих технологій. } \\
\text { - Передбачення технологічних змін і пов' язаних з ними рішень у } \\
\text { внутрішній політиці та у сфері зовнішніх відносин. }\end{array}$ \\
\hline Японія & $\begin{array}{l}\text { - Прогнозування розвитку науки та високих технологій. } \\
\text { - Моделювання способів практичного використання нових технологій } \\
\text { у виробництві та у повсякденному житті громадян. }\end{array}$ \\
\hline $\begin{array}{l}\text { Велика } \\
\text { Британія }\end{array}$ & $\begin{array}{l}\text { Акцентування уваги на моделі майбутньго для окремих складників } \\
\text { економіки та верств суспільства, а саме для: } \\
\text { - окремих регіонів - «регіональний форсайт»; } \\
\text { - малого і середнього бізнесу; } \\
\text { - окремих соціальних груп, зокрема молоді - «молодіжний форсайт». }\end{array}$ \\
\hline Австрія & $\begin{array}{l}\text { - Ініційований «згори», коли зміст форсайт-проєктів визначається } \\
\text { органами центральної влади. } \\
\text { - Переважно орієнтований на ідентифікацію інноваційного потенціалу } \\
\text { країни. }\end{array}$ \\
\hline
\end{tabular}


Продовження табл. 4

\begin{tabular}{|l|l|}
\hline Швеція & $\begin{array}{l}\text { - Ініційований «знизу», коли зміст форсайт-проєктів визначають } \\
\text { спільноти громадян, тому спирається на численні методи дослідження } \\
\text { суспільної думки та участі громадян у формуванні візії майбутнього. }\end{array}$ \\
& $\begin{array}{l}\text { медієнтований на сфери задоволення першочергових потреб громадян: } \\
\text { медицина та охорона здоров’я, біоресурси, соціальна інфраструктура, } \\
\text { інформаційні канали і комунікації, індустрія послуг, освіта. }\end{array}$ \\
\hline
\end{tabular}

Джерело: складено авторами на основі [24-26].

Інформація, подана в аналітичній табл. 4, дає підстави для висновку про те, що національна модель форсайта залежить не тільки від ресурсних можливостей країн для організації досліджень. Адже розглянуті країни є країнами високого рівня розвитку. Ймовірно, що визначальні ознаки моделі форсайта більшою мірою залежать від цінностей суспільства. Ці цінності, як свідчать факти, можуть бути різними: домінування у світовій економіці, забезпечення випереджального розвитку окремих регіонів або спільнот, якість життя громадян тощо.

Показовим є те, що форсайт-проєкти на початку XXI ст. уже стосуються моделювання майбутнього для об'єднання країн. Зокрема, у 2004 - 2005 рр. був виконаний проєкт технологічного форсайта на 2015 - 2030 рр. для країн ЄС. За результатами проєкту визначено:

- 40 пріоритетних інноваційних технологій;

- 4 пріоритетні сфери в царині:

- нанотехнологій та нових матеріалів;

- технологій інформаційного суспільства;

- технологій наук про життя, геноміки і біотехнологій;

- технологій сталого розвитку, глобальної зміни клімату й екосистеми [28].

Результати форсайт-проєкту для країн ЄС використовуються при розробці інноваційної політики СС.

Для дослідження ролі форсайта у публічному управлінні українською економікою важливо узагальнити досвід форсайт-проєктів. При цьому доцільно розмежувати форсайт-проєкти загальнонаціонального рівня, рівня окремих секторів та місцевого рівня. Останні набули в Україні особливого значення у зв'язку зі здійснюваною реформою децентралізації й розбудови місцевого самоуправління.

В Україні здійснюються форсайт-проєкти загальнонаціонального рівня, що характеризуються такими особливостями.

Форсайт-дослідження 2004 - 2006 рр. за Національною програмою «Українська наука, технології та інновації 2025» (Ukrainian STI 2025):

- використовувалися такі методи: Делфі-опитування, конференції, семінари, круглі столи;

- сформульовано пріоритетні напрямки науково-технічного розвитку, підготовлено рекомендації урядові щодо використання 
державного бюджету, визначено вимоги до системи навчання форсайтпроєктуванню [29].

Форсайт-дослідження 2007 р. на виконання Державної програми прогнозування науково-технологічного розвитку в Україні на 2008 2012 pp. [30]:

- застосовано методи сценарного прогнозування науковотехнологічного розвитку, експертні панелі, семінари та круглі столи;

- уточнено перелік критично важливих технологій за пріоритетними напрямками науки та техніки;

- визнано в якості провідної організації супроводу виконання проєкту Український інститут науково-технічної і економічної інформації (УкрIНТЕІ).

Форсайт-дослідження «Людський капітал України 2025», здійснене у 2012 p. [31]:

- використано методи експертного оцінювання із залученням широкого кола підприємців та менеджерів вищої ланки;

- визначено основні тренди змін людського капіталу України та ймовірні сценарії його розвитку, а також окреслено стратегічні ініціативи українського бізнесу на ринку праці;

- ініціаторами дослідження стали: організація «ВікіСітіНоміка», оргкомітет «Human Capital Forum» та Київська Бізнес Школа.

Проєкт «Форсайт економіки України: середньостроковий i довгостроковий (2020 - 2030 рр.) часові горизонти» [32] було презентовано у 2015 р. Основні характеристики проєкту є такими:

- використовувалися методи: огляди літератури, екстраполяція тенденцій, метод Дельфі, SWOT-аналіз, розробка сценаріїв;

- результатом проєктування майбутнього стало виокремлення кластерів, які, на думку експертів, робитимуть найбільший внесок в економіку України у 2020-2030 pр., а саме: аграрного сектору (очікувана частка внеску в економіку 17\%), військово-промислового комплексу (15\%), інформаційно-комунікаційних технологій (12\%), створення нових речовин і матеріалів, нанотехнологій (12\%), енергетики $(11 \%)$, високотехнологічного машинобудування (8\%), інших кластерів економіки (25\%);

- ініціаторами проєкту стали науковці Світового центру даних 3 геоінформатики і сталого розвитку Міжнародної ради з науки (ICSU) та Інституту прикладного системного аналізу при Національному технічному університеті України «Київський політехнічний інститут імені Ігоря Сікорського».

Форсайт-дослідження «Доктрина збалансованого розвитку: УКРАЇНА-2030» у 2017 р. [33]:

- використано методи дослідження трендів, рейтингового оцінювання, сценарного прогнозування; 
- визначено стратегічні пріоритети та вперше окреслено нову соціально-орієнтовану модель розвитку України з креативним потенціалом нації у якості основної рушійної сили;

- ініціаторами проєкту стали науковці Національного технічного університету України «Київський політехнічний інститут імені Ігоря Сікорського», Київського національного університету ім. Тараса Шевченка, ДВНЗ «Київський національний економічний університет ім. Вадима Гетьмана», Національного університету біоресурсів і природокористування України, Національного університету «Києво-Могилянська академія».

Форсайт-проєкт від фонду ім. Ф. Еберта 2018 р. $з$ визначенням майбутнього до 2027 р. [34]:

- зроблено акцент на методі сценарного прогнозування;

- визначено чотири сценарії розвитку України до 2027 р. 3 урахуванням визначальних чинників впливу на майбутнє України, включно з міжнародними чинниками;

- ініціаторами проєкту стали іноземні фахівці фонду ім. Ф. Еберта та українські фахівці Міністерства економічного розвитку і торгівлі України [35].

В Україні здійснювалися прогнозно-аналітичні дослідження за окремими секторами та видами діяльності, як, наприклад, енергетика, біотехнології, нові матеріали, інформаційно-комунікаційні технології [36]. До секторних форсайт-досліджень належить, зокрема, проєкт 2018 р. Метою проєкту стало створення системи підготовки та перепідготовки фахівців природничого і технічного спрямування, виходячи з цілей сталого соціально-економічного розвитку України до 2025 p. [37].

В Україні розпочато серію форсайт-проєктів місиевого (муніципального) рівня. Найбільш перспективними виглядають проєкти, пов'язані зі стратегією розвитку об'єднаних територіальних громад (ОТГ). Особливості форсайт-проєктів на місцевому рівні можна ілюструвати на таких прикладах.

Форсайт-дослідження для Зеленодольської та Піщанської ОТГ Дніпропетровської області 2018 р. [38]:

- застосовано метод експертних панелей для передбачення у недалекій перспективі з метою так званого «швидкого форсайта»;

- визначено перспективні напрямки (сфери) змін, які можуть забезпечити успіх у майбутньому, а саме:

1) використання сучасних технологій переробки відходів промислових підприємств та покращення екології в районі;

2) створення системи виробництва, переробки та торгівлі місцевою сільськогосподарською продукцією;

3) благоустрою населених пунктів у частині транспортного сполучення, водопостачання тощо; 
4) реалізації правильної молодіжної політики, включно зі створенням місць привабливого працевлаштування, місць культурного відпочинку тощо;

- ініціаторами проєкту стали представники місцевого бізнесу, місцевих закладів освіти та охорони здоров'я, активні члени спортивних та культурних громадських організацій.

Форсайт-дослідження «Молодь у розвитку місцевої громади» 2018 р. у рамках проєкту «Інтегрований розвиток міст України» [39], який виконує німецька урядова компанія «Deutsche Gesellschaft für Internationale Zusammenarbeit (GIZ) GmbH»:

- використано метод дискусійних панелей для обговорення та уточнення концепції розвитку міста Полтава;

- створено «дорожню карту» спільних дій місцевої влади, громадських організацій, навчальних закладів та бізнесу для досягнення цілей Концепції «Полтава 2030»

- ініціаторами стали Полтавська міська рада та комунальна організація «Інститут розвитку міста» в межах загальноукраїнського проєкту «Інтегрований розвиток міст в Україні».

На обгрунтування важливості передбачень та створення візії майбутнього в усіх сферах розглянемо приклад, пов'язаний з формуванням конкурентного середовища української економіки. Зрозуміло, що провідним учасником цього процесу має бути орган державної влади Антимонопольний комітет України (АКУ). Попри природні функції захисту конкуренції, покладені на цей орган, його дії дають підстави для звинувачень у перешкоджанні конкуренції. Якщо такі звинувачення $€$ обгрунтованими, то йдеться про негативну тенденцію, яка спотворюватиме привабливу модель майбутнього.

За умови, що сучасна економічна ситуація містить негативні тенденції, зокрема у формуванні конкурентного середовища, форсайтдослідження мають спиратися на усвідомлення цих тенденцій. Про які тенденції свідчать факти?

По-перше, зменшується частка українських ринків з так званою «конкурентною структурою». У 2000 р. фіксувалося 90\% ринків 3 конкурентною структурою. У 2015 р. ця частка становила лише 64\%. Відтак, ідеться про тенденцію до згортання конкурентного середовища [40].

По-друге, загальне згортання конкурентного середовища відбувається на тлі зростання частки олігопольних ринків. У 2000 р. ця частка становила 8\%, а в 2015 р. вона зросла до 33\%. За панування на ринку «жорсткого олігопольного ядра», умови господарювання для фірм так званої «конкурентної периферії» перестають бути власне конкурентними. На цьому, зокрема, акцентовано увагу українських дослідників. Якщо олігополізація ринків стає об'єктивним фактом, то передбачення стратегічних рішень фірм на таких ринках має ставати головним завданням Антимонопольного комітету України. 
По-третє, 32010 р. відбувається поступове зростання частки ринків 3 ознаками індивідуального домінування, тобто монополізованих ринків. На таких ринках конкуренція перестає існувати остаточно. До прикладу, в 2015 р. рівень конкуренції на товарних ринках скоротився до історичного мінімуму і становив $42,7 \%$ [41].

По-четверте, згортання конкуренції посилюється на тлі відсутності однакових правил для економічних суб'єктів щодо режиму оподатковування, надання субсидій, привілеїв пільгового використання земельних ділянок, інфраструктурних об'єктів тощо [42]. Відтак, можна фіксувати тенденцію згортання конкуренції під впливом дій влади.

В українських форсайт-дослідженнях мають формуватися сценарії майбутнього, з огляду на об’єктивні наслідки згортання конкуренції під впливом хибної антимонопольної політики. Образ такого майбутнього міг би бути змодельований так (рис. 4):

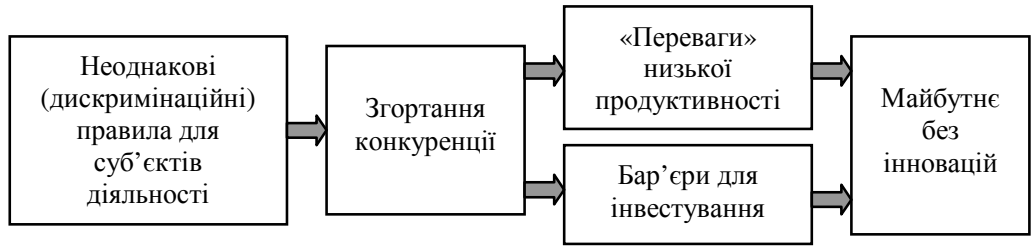

\section{Рис. 4. Можливі наслідки для майбутнього від згортання конкуренції}

Дюсерело: створено авторами самостійно.

На рис. 4 ілюстровано ідею формування «майбутнього без інновацій» під впливом дискримінаційних правил та згортання конкуренції в поточному періоді. Згортання конкуренції формує принаймні два достатньо очевидні наслідки в українській економіці, а саме:

- неприродні переваги для економічних суб'єктів, що не опікуються продуктивністю, бо досягають вищих доходів завдяки монопольному становищу;

- непривабливість національної економіки для інвесторів.

Про непривабливість української економіки для іноземних інвесторів саме через згортання конкуренції на тлі несприятливого інституційного середовища свідчать результати соціологічного дослідження. Показовим $\epsilon$ те, що 92\% опитаних іноземних інвесторів у дослідженні, на яке ми посилаємося, вже мали досвід інвестування в українську економіку. Дослідження від Європейської бізнес-асоціації, інвестиційної компанії Dragon Capital та Центру економічної стратегії [43] дало такі результати:

- двома головними перешкодами для іноземних інвестицій визнано поширення корупції та недовіру до судової системи; 
- тривалий військовий конфлікт визнано менш загрозливим явищем для інвестування, ніж монополізацію ринків та засилля олігархічного капіталу.

За результатами здійсненого дослідження форсайта ми робимо такі загальні висновки.

Форсайт, як формування образу майбутнього та власне підвалин цього майбутнього в сучасній дійсності, став інструментом публічного управління на загальнонаціональному та місцевому рівнях у багатьох країнах. Успішні приклади форсайт-досліджень та форсайт-проєктів мають ставати об'єктом аналізу для узагальнень та використання публічною владою всіх країн.

Попри деякий досвід форсайт-досліджень, український форсайт перебуває на початковому етапі становлення саме як інструмент публічного управління. Про це, зокрема, свідчить таке:

- використовується обмежене коло - не більше трьох-чотирьох методів при розробці кожного форсайт-проєкту. Натомість, однією 3 вимог форсайта $є$ застосування не менш, ніж шістьох методів для гарантування необхідного рівня надійності передбачень;

- результати форсайт-досліджень здебільшого обмежуються лише загальними висновками про загальне бачення можливого майбутнього країни. Ініціаторами таких досліджень стають наукові університетські спільноти. Натомість, ними мали б ставати органи центральної та місцевої влади, зацікавлені в конкретизації цілей окремих етапів створення майбутнього, часових проміжків їх реалізації та застосовуваних інструментів досягнення цілей;

- бракує досліджень, присвячених майбутньому окремих секторів національної економіки, окремих регіонів та територіальних утворень, а також присвячених конкретним діям 3 формування майбутнього у теперішньому часі;

- результати форсайт-досліджень використовуються лише як джерело певної інформації, яка, ймовірно, братиметься кимось до уваги. Не створено системи інституалізації форсайта. Ця система мала б визначати алгоритми врахування результатів форсайт-досліджень у цільових програмах уряду, у стратегіях розвитку, в економічній політиці конкретного періоду;

- бракує системи постійної взаємодії для формування візії майбутнього між органами центральної влади, 3 одного боку, та органами місцевої влади, місцевого самоврядування, громадянським суспільством, - 3 іншого;

- створення образу майбутнього, за умов неприродних дій інститутів публічної влади, має спиратися на оцінювання не лише позитивних трендів, а й негативних трендів, які деформують майбутнє. 


\section{Лimepamypa:}

1. Martin B. R. Foresight in science and technology. Technology Analysis \& Strategic Management. 1995. Vol. 7. №2. P. 139-168. URL : https://www.researchgate.net/publication/201168998_Foresight_in_Science_ and_Technology.

2. Heraud J. A., Cuhls K. Current Foresight Activities in France, Spain and Italy. Technological Forecasting and Social Change. 1999. Vol. 60.

3. Becker P. Corporate foresight in Europe: a first overview. Luxembourg : office for official publications of the European communities, 2003. P. 7.

4. Habegger B. Strategic foresight in public policy: reviewing the experiences of the UK. Singapore and the Netherlands. 2010. Futures 42. P. 49-58.

5. Hideg E. Theory and practice in the field of foresight. Foresight. 2007. №9(6). P. 36-46.

6. United Nations Industrial Development Organization. UNIDO Technology Foresight Manual. Vienna: United Nations. 2005. URL : http://www.unido.org/foresight/registration/volume1_unido_tf_manual.pdf.

7. Foresight Group. URL : http://www.foresightgroup.eu.

8. Community research and development information service CORDIS. URL : http//cordis/europa/eu/.

9. Гапоненко Н. В. Форсайт. Теория. Методология. Опыт : монография. Москва : ЮНИТИ-ДАНА, 2008. 239 с.

10. Смельяненко Л. М. Форсайт-методологія стратегічного управління інноваційним розвитком суспільства. Вісник Східноукраїнського національного університету імені В. Даля. 2008. №10(128). URL : http://www.nbuv.gov.ua/portal/Soc_Gum/VSUNU/2008_10_2/emeljanenko.pdf.

11. Кизим М. О., Матюшенко I. Ю., Шостак I. В., Данова М. О. Форсайт-прогнозування пріоритетних напрямів розвитку нанотехнологій і наноматеріалів у країнах світу й Україні : монографія. Харків : ВД «НЖЕК», 2015. $272 \mathrm{c}$.

12. Рибінцев В. О., Клопов І. О. Форсайт як технологія реалізації стратегії розвитку економіки. Бізнес та інтелектуальний капітал. Інтелект XXI. 2017. №3. C. 87-94.

13. Что такое Форсайт? Международный научно-образовательный Форсайт-центр, Институт статистических исследований и экономики знаний НИУ ВШЭ. URL : http://foresight.hse.ru.

14. Popper R, Georghiou L, Miles, I. and Keenan M. Evaluating Foresight: Fully-Fledged Evaluation of the Colombian Technology Foresight Programme (CTFP), Cali: Universidad del Valle. 2010. URL : http://community.iknowfutures.eu/pg/file/popper/view/2204/evaluatingforesight-fullyfleded-evaluation-of-ctfp.

15. Форсайт. URL : http://aurora-expertum.ru/2009/03/forsajt/. 
16. Паладченко О. Ф., Молчанова І. В. Сучасні підходи і методи проведення прогнозних досліджень: світовий досвід і можливість його використання в Україні. Наука, технології, інновації. 2018. №2. С. 23-32.

17. European Commission, Unit RTD-K. Thinking, debating and shaping the future: Foresight for Europe: Final report prepared by a High Level Expert Group for the European Commission. European Commission. Bruxelles. 2002.

18. Cuosa T. Practicing strategic foresight in government. The cases of Finland, Singapore and European Union. Singapore: S. Rajaratnam Studies, 2011. $116 \mathrm{p}$.

19. Лабуркина П. Форсайт: аналитический обзор. URL: http://20102030.ru/files/Forsait_analitichekii_obzor.doc.

20. Tools for Futures Thinking and Foresight Across UK Government November 2017. URL: https://assets.publishing.service.gov.uk/government/ uploads/system/uploads/attachment_data/file/674209/futures-toolkitedition-1.pdf.

21. Horton A. Simple guide to successful foresight. Foresight. 1999. №1(1). P. 59.

22. Gaviigan J. P., Scapolo F., Keenan M., Miles I. A Practical Guide to Regional Foresight. European Communities. 2001. 122 p. URL : http://foresight.jrc.ec.europa.eu/documents/eur2012 8en.pdf.

23. Cagnin C., Keenan M., Johnston R., Scopolo F., Barré R. (eds) Future-Oriented Technology Analysis. Strategic Intelligence for an Innovative Economy. Springer. Germany. 2008.

24. United Nations Industrial Development Organisation Technology foresight manual. Vienna, 2005. Vol. 1-2.

25. Панина О. В., Ващенко Р. Р., Остроухов Л. А. Зарубежный опыт применения форсайт-проектов. Евразийский союз ученых. 2014. №5-6(5). C. 86-87.

26. Kononiuk A., Sacio-Szymańska A., Gáspár J. How do companies envisage the future? Functional foresight approaches Engineering Management in Production and Services. 2017. Vol. 9. Issue 4. P. 21- 33.

27. The European Foresight Monitoring Network: collection of efmn briefs part 2. European Commission, European Union. URL: http:/globaltrends.thedialogue.org/wpcontent/uploads/2014/10/TheEuopean-Foresight-MonitoringNetwork-Collection-of-EFNM-Briefs-PartTwo.pdf.

28. The European Foresight Monitoring Network. Collection of EFMN Briefs. Part 1. Luxembourg: Office for Official Publications of the European Communities. 2008. 481 p. URL: https://ec.europa.eu/research/ social-sciences/pdf/other_pubs/efmn-report_en.pdf.

29. Державна програма прогнозування науково-технологічного розвитку на 2008-2012 рр. Затверджена постановою КМУ від 11.09.2007 №1118. URL: https://zakon.rada.gov.ua/laws/show/1118-2007-П. 
30. Людський капітал України - 2025. Підсумки форсайта. URL : http://wikicitynomica.org/future/lyudskiy-kapitalukraini-2025-pidsumkiforsaytu.html.

31. Форсайт економіки України: середньостроковий (2015 2020 рр.) і довгостроковий $(2020$ - 2030 рр.) часові горизонти / наук. керівник проєкту акад. НАН України М. З. Згуровський. Київ: НТУУ «КПІ», 2015. $136 \mathrm{c}$.

32. Україна 2030: Доктрина збалансованого розвитку. Видання друге. Львів: Кальварія, 2017. 164 с.

33. Форсайт Україна. Чотири сценарії розвитку України / Під ред. С. Шарап, Р. Крумм, С. Вайс. Відень. 2018. 27 с.

34. Кубів С. Україні потрібна візія майбутнього з горизонтом до 2050 року. URL : https://www.kmu.gov.ua/news/stepan-kubiv-ukrayinipotribna-viziya-majbutnogo-z-gorizontom-do-2050-roku.

35. Форсайт - стратегічні маркетингові дослідження науковотехнологічного розвитку України. URL: http://www.uintei.kiev.ua/foresight/ index.php.

36. Форсайт 2018: Аналіз підготовки і перепідготовки фахівців природничого і технічного спрямування, виходячи з цілей сталого соціально-економічного розвитку України до 2025 року. Київ : НТУУ «КПІ імені Ігоря Сікорського», «Політехніка», 2018. 32 с.

37. Квітка С. А. Форсайт як технологія проектування майбутнього: новітні механізми взаємодії публічної влади, бізнесу та громадянського суспільства. Аспекти публічного управління. 2019. Т. 7. №4. С. 5-16.

38. Форсайт-форум «Молодь у розвитку місцевої громади». URL : https://sites.google.com/a/polytechnic.co.cc/ppk/novini/forsajt-forummolod vrozvitkumiscevoiegromadi.

39. Звіт Антимонопольного комітету України за 2015 рік. Київ : Антимонопольний комітет України, 2015. 135 с. С. 5.

40. Герасименко А. Г. Еволюція конкуренції у вітчизняній торгівлі. Конкурентоспроможність національної економіки : матеріали XVII Міжнародної науково-практичної конференції, 5-6 жовтня 2017 р. Київ, 2017. С. 24-27.

41. Огляди ОЕСР законодавства і політики у сфері забезпечення конкуренції: Україна 2016. Звіт щодо виконання попередніх рекомендацій. Антимонопольний комітет України. URL : http://www.amc. gov.ua/amku/doccatalog/document?id=133482\&schema=main.

42. Нікитенко Д. В. Проблеми інституціоналізації захисту конкуренції в Україні. Конкурентоспроможність національної економіки: Матеріали XVII Міжнародної науково-практичної конференції, 5-6 жовтня 2017 р. Київ, 2017. С. 88-91.

43. Новини бізнесу. URL : http://biz.nv.ua/ukr/markets/investorinazvali-osnovni-prichini-nedoviri-ukrajini-1873488.html. 


\title{
ІНСТИТУЦЙНИЙ ДИЗАЙН МАКРОФІНАНСОВОЇ БЕЗПЕКИ ДЛЯ СТАБІЛІЗАЦІЇ НАЦІОНАЛЬНОЇ ЕКОНОМІКИ
}

\author{
Радіонова Ірина Федорівна, \\ доктор економічних наук, професор, \\ ДВНЗ Київський національний університет імені Вадима Гетьмана, \\ ВНЗ «Університет економіки та права «КРОК», \\ ORCID: https://orcid.org/0000-0002-0941-2867,
}

\begin{abstract}
Мальковська Юлія Борисівна, магістр публічного управління та адміністрування, аспірантка PhD програми «Публічне управління та адміністрування», ДВНЗ Київський національний університет імені Вадима Гетьмана, ORCID: https://orcid.org/0000-0001-6052-0639
\end{abstract}

Анотація. Розділ присвячено науковій та прикладній для публічного управління економікою проблемі формування національного інституційного дизайну в спеціальній сфері. Йдеться про сферу макрофінансової стабільності (безпеки). Важливість цієї сфери $є$ доведеною (верифікованою) в Україні та в інших країнах. Тому для обгрунтування висновків і управлінських пропозицій аналізувався не лише стан публічного управління цією сферою в Україні, а й досвід регулювання макрофінансових дисбалансів у ЄС. Результатом дослідження стала схема (певний алгоритм) дій з формування дизайну макрофінансової безпеки для української економіки та суспільства.

Ключові слова: макрофінансова стабільність (безпека), табло макрофінансових дисбалансів, інституційний дизайн, матриця взаємодії інститутів влади.

Актуальність дослідження проблеми формування інституційного дизайну макрофінансової безпеки для української економіки та суспільства пояснюється принаймні двома обставинами. По-перше, макрофінансовій сфері національної економіки бракує стабільності, а нагромаджені у ній дисбаланси є загрозливими для іiі цілісності. Подруге, макрофінансові дисбаланси не стали об'єктом спеціального моніторингу, аналізу, коригування, запобігання органами публічної (державної) влади. Це виявляється у несформованості правил, алгоритмів, процедур, стимулів, санкцій, каналів взаємодії урядів зі спільнотами та суспільством тощо. Отже, йдеться про відсутність того, що називається інституційним дизайном. Останній покликаний забезпечувати оцінювання, запобігання, коригування макрофінансових диспропорцій. А макрофінансова стабільність у такий спосіб 3 побажання урядів перетворюється на економічну дійсність. 
Метою цього дослідження є обгрунтування певного алгоритму дій 3 формування інституційного дизайну, покликаного протидіяти формуванню й поглибленню макрофінансових дисбалансів в українській економіці.

Наукова й управлінська проблема формування інституційного дизайну макрофінансової безпеки передбачає відповіді на декілька питань. Передусім постає питання про власне зміст поняття «макрофінансова безпека». Це випливає зі зрозумілої логіки міркувань: оскільки макрофінансова безпека $є$ змістом (і метою) інституційного дизайну, остільки між змістом та формою має досягатися відповідність. Останнє передбачає якомога точнішу ідентифікацію змісту. Не менш важливим $є$ й питання про зміст поняття «інституційний дизайн», про необхідні складники (елементи) сформованого дизайну та про особливості інституційного дизайну в українській економіці, з огляду на існуючі економічні дисбаланси та чинну систему публічного управління. Досліджуючи основну проблему, ми намагатимемося частково відповідати й на ці питання.

Наша логіка дослідження спирається на такі два припущення.

Перше: макрофінансова сфера може й має бути виокремлена як певний сегмент національної економіки з властивими їй пропорціями (балансами), відповідно - показниками для оцінювання та інститутами публічної влади для моніторингу, контролю і коригування.

Друге: поняття (явища) «стабільність» та «безпека» є щільно пов'язаними, а, можливо, й синонімічними. Маємо на увазі той незаперечний факт, що існування макрофінансової стабільності означає перебування економіки у безпечному стані. I, навпаки, макрофінансова безпека, що виявляється у відсутності надмірних дисбалансів, одночасно означає існування макрофінансової стабільності. Якщо поняття «макрофінансова стабільність» та «макрофінансова безпека» і мають відмінності, то вони не $є$ принципово важливими для нашого дослідження.

Термін «макрофінансова» застосовується не лише в контексті безпеки, а й в інших контекстах, а саме: «макрофінансові диспропорції» [1], «макрофінансова стабільність» [2], «макрофінансовий аналіз» [3] тощо. Активність уживання цих термінів зростала після світової фінансової кризи 2008 - 2010 рр.

Аналіз уживання згаданих пов'язаних понять дає підстави для висновку про існування двох тлумачень, відповідно, двох застосувань терміна «макрофінансове»: спрощеного (загального) та більш складного (конкретизованого).

Спрощений варіант використання терміна «макрофінансове», наприклад, знаходимо у фундаментальній роботі британських та американських дослідників, присвяченій оптимізації політики. У 
дослідженні йдеться про макрофінансову стабільність як таку, що передбачає відповідність фінансової системи загальному стану всієї економіки [4]. Фактично, «макрофінансове» тлумачиться як взаємодія (узгодження) фінансового та макроекономічного.

Складніший (більш конкретизований) варіант застосування терміна «макрофінансове» пов'язаний з різними алгоритмами (методиками) оцінювання дисбалансів національних економік. Ідеться передовсім про встановлений для країн ЄС перелік (Табло) показників та їх орієнтовних порогових значень для оцінювання дисбалансів i застосування процедури їх подолання («MIP Scoreboard»). Попри те, що дисбаланси називаються в офіційному документі $\mathrm{CC}$ макроекономічними (Macroeconomic imbalances procedure - MIP), їx значна частина, незаперечно, має «подвійну» макрофінансову природу. Про це свідчить власне зміст показників для оцінювання стану національних економік $\mathrm{CC}$, поданий у табл. 1 .

Таблиия 1

Індикатори для виявлення макроекономічних дисбалансів у країнах ЄС 2011 та 2018 pp.

\begin{tabular}{|c|c|c|}
\hline $\begin{array}{c}\text { Сфера } \\
\text { дисбалансів } \\
\end{array}$ & Ключові показники & $\begin{array}{c}\text { Рекомендовані } \\
\text { порогові значення }\end{array}$ \\
\hline \multicolumn{3}{|c|}{ Спільне для MIP Scoreboard у 2011 та 2018 рp. } \\
\hline \multirow{5}{*}{$\begin{array}{l}\text { Зовнішня/ } \\
\text { реалізації } \\
\text { конкурентної } \\
\text { спроможності } \\
\text { країни }\end{array}$} & $\begin{array}{l}\text { 1. Середня за } 3 \text { останні роки величина сальдо } \\
\text { рахунку поточних операцій (у\% до ВВП) }\end{array}$ & від $-4 \%$ до +6\% ВВП \\
\hline & $\begin{array}{l}\text { 2. Чиста міжнародна інвестиційна позиція (\% } \\
\text { до ВВП) }\end{array}$ & $-35 \%$ ВВП \\
\hline & $\begin{array}{l}\text { 3. Зміна за } 3 \text { останні роки реального ефективного } \\
\text { обмінного курсу (РЕОК), обчисленого на основі } \\
\text { дефлятора ВВП відносно валют } 35 \text { (у МІР } \\
\text { 2011) /42 (у МІР 2018) розвинених країн }\end{array}$ & $\begin{array}{l}\text { від }+5 \% \text { до -5\% для } \\
\text { країн-членів Єврозони; } \\
\text { від }+11 \% \text { до }-11 \% \text { для } \\
\text { всіх інших країн ЄС }\end{array}$ \\
\hline & $\begin{array}{l}\text { 4. Зміна за останні } 5 \text { останніх років частки } \\
\text { експорту країни у світовому експорті (у \%) }\end{array}$ & $6 \%$ \\
\hline & $\begin{array}{l}\text { 5. Зміна за } 3 \text { останні роки номінальної вартості } \\
\text { робочої сили в розрахунку на одиницю } \\
\text { продукції }(\%)\end{array}$ & $\begin{array}{l}\text { +9\% для країн-членів } \\
\text { Сврозони; } \\
+12 \% \text { для всіх інших } \\
\text { країн ЄС }\end{array}$ \\
\hline \multirow{5}{*}{ Внутрішня } & $\begin{array}{l}\text { 6. Річна дефльована (реальна) зміна } \\
\text { гармонізованого індексу цін на житло (\%) }\end{array}$ & $+6 \%$ \\
\hline & $\begin{array}{l}\text { 7. Кредитування приватного сектору } \\
\text { (нефінансових корпораиій, домогосподарств, } \\
\text { некомериійних організацій) на консолідованій } \\
\text { основі (\% ВВП) }\end{array}$ & $\begin{array}{l}15 \%(\mathrm{y} \text { MIP 2011) / } \\
14 \% \text { ВВП (y MIP } \\
2018)\end{array}$ \\
\hline & $\begin{array}{l}\text { 8. Заборгованість приватного сектору } \\
\text { (вартість позик і цінних паперів, окрім акцій), } \\
\text { обчислена на консолідованій основі (\% ВВП) }\end{array}$ & $\begin{array}{l}160 \% \text { (y MIP 2011)/ } \\
133 \% \text { ВВП (y MIP } \\
2018)\end{array}$ \\
\hline & 9. Загальний державний борг (\% ВВП) & $60 \%$ ВВП \\
\hline & $\begin{array}{l}\text { 10. Середній за } 3 \text { останні роки рівень } \\
\text { безробіття (\%) }\end{array}$ & $10 \%$ \\
\hline
\end{tabular}


Продовження табл. 1

\begin{tabular}{|c|c|c|}
\hline \multicolumn{3}{|c|}{ Особливе (додаткове) у MIP Scoreboard у 2018 р. } \\
\hline Внутрішня & $\begin{array}{l}\text { Річна зміна боргових зобов'язань фінансового } \\
\text { сектору на неконсолідованій основі (\%) }\end{array}$ & $16,5 \%$ \\
\hline \multirow{3}{*}{$\begin{array}{l}\text { Сфера } \\
\text { зайнятості }\end{array}$} & $\begin{array}{l}\text { Зміна за } 3 \text { останні роки рівня активності } \\
\text { населення віком від } 15 \text { до } 64 \text { років }\end{array}$ & $-0,2$ пункти \\
\hline & $\begin{array}{l}\text { 3міна за } 3 \text { останні роки рівня довготермінового } \\
\text { безробіття (у \%) активного населення віком від } \\
15 \text { до } 74 \text { років }\end{array}$ & 0,5 пункти \\
\hline & $\begin{array}{l}\text { Зміна за } 3 \text { останні роки рівня безробіття молоді } \\
\text { віком від } 15 \text { до } 24 \text { років }\end{array}$ & 2 пункти \\
\hline
\end{tabular}

Джерело: розроблено авторами на основі [5; 6].

Наведена аналітична таблиця віддзеркалює інформацію про показники для оцінювання стабільності національних економік та нормативи для визначення міри відхилення від безпечних меж. Якщо документами 2011 р. передбачалося використання 10-х показників, 3 яких 6 мали очевидну макрофінансову природу, то нині їх загальна кількість зросла до 14-х, з яких 7 можуть тлумачитися як макрофінансові. До показників «подвійного» - макроекономічного й, водночас, фінансового змісту - належать, на наш погляд, такі:

- середня за 3 останні роки величина сальдо рахунку поточних операцій (у \% до ВВП);

- чиста міжнародна інвестиційна позиція (\% до ВВП);

- зміна за 3 останні роки реального ефективного обмінного курсу (РЕОК), обчисленого на основі дефлятора ВВП відносно валют розвинених країн;

- кредитування приватного сектору, оцінене на консолідованій основі (\% ВВП);

- заборгованість приватного сектору, обчислена на консолідованій основі (\% ВВП);

- загальний державний борг (\% ВВП);

- річна зміна боргових зобов'язань фінансового сектору на неконсолідованій основі (\%).

Наведені 7 показників є фінансовими, оскільки стосуються загального стану фінансових активів та пасивів, а саме: інвестицій, кредитів, боргових зобов'язань, національної валюти. Водночас, вони $\epsilon$ макроекономічними з огляду на те, що віддзеркалюють пропорції усієї національної економіки. Тому вони сконструйовані так, що передбачають подання та оцінювання на тлі таких макроекономічних змінних, як: досягнутий обсяг ВВП, загальний рівень цін, взаємодія інституційних секторів тощо.

Аналіз змін в оцінюванні дисбалансів - від Маастрихтських критеріїв 1992 [7] до Табло «MIP Scoreboard» 2011 р. та Табло «МIP Scoreboard» 2018 р. - дає підстави для важливих узагальнень щодо 
еволюції змісту поняття «макрофінансове». Зокрема, не можна не помітити факт зміщення акцентів у Табло від показників, переважно, 3 фінансовим змістом на користь показників, які характеризують стан реального сектору економіки. Така зміна є реакцією на події, пов'язані 3 фінансовою кризою 2008 - 2010 рр. та усвідомленням необгрунтованого переоцінювання ролі фінансового сектору в розвитку національних та світової економік. Показовим є те, що у Табло 2018 р. подано 4 нові показники, 3 яких 3 стосуються зайнятості активного населення, зайнятості молоді, тривалості безробіття. Отже, йдеться про переміщення акценту на трудовий потенціал реального сектору економіки.

Ми доходимо висновку, що в якості макрофінансових мають розглядатися процеси (явища), відповідно - набір показників, осердя яких складають ті, що стосуються руху фінансових активів/пасивів. Однак, цей перелік має охоплювати (імплементувати) й ті показники реальної економіки, які безпосередньо пов'язані 3 цим рухом та визначають його. Йдеться, до прикладу, про показники, серед яких:

- сукупні витрати загалом та чистий експорт зокрема;

- загальний рівень цін;

- співвідношення заробітної плати та загальної продуктивності;

- безробіття та зайнятість.

Важливим моментом у тлумаченні змісту поняття «макрофінансове» $\epsilon$ визнання того, що набір показників для оцінювання макрофінансових диспропорцій не може залишатися незмінним. Показовим, наприклад, $\epsilon$ те, що на початку 1990-х pр., у складі 4-х Маастрихтських критеріїв, один стосувався загального рівня цін, визначеного за темпом інфляції. У сучасних критеріях - Табло МIP - ідеться лише про індекс иін на житло. Причиною такої зміни акцентів, імовірно, є втрата для країн ЄС вже у 2010-х рр. актуальності проблеми надмірної інфляції. Натомість, на початку 1990-х рр. ця проблема була актуальною для них як така, що створювала загрози для макроекономічної стабільності. Попри все, загальний рівень цін, у який би спосіб він не відображався через різні форми оцінювання інфляції, через дефлювання номінальних показників на індекс цін тощо, $-\epsilon$ частиною явища «макрофінансове».

На наш погляд, для більш точної ідентифікації змісту поняття «інституційний дизайн макрофінансової безпеки» мають використовуватися показники з Табло МІР країн СС для оцінювання дисбалансів. Незаперечно, що в конкретних умовах окремих країн, зокрема в Україні, ці показники потребуватимуть певної модифікації з метою кращого пристосування. До прикладу, перманентні загрози небезпечних рівнів української інфляції спричинятимуть необхідність імплементації безпосередніх іï показників у особливе «Табло українських дисбалансів». Імовірно, що тим самим «специфічно українським» показником дисбалансів мав би бути показник рівня тінізації економіки, з огляду 
на фактичну неспівставно значну щодо інших країн світу частку тіньової економіки в структурі національної економіки.

Позитивна відповідь на питання про цінність досвіду країн ЄС для уточнення змісту поняття «макрофінансове» може грунтуватися на таких аргументах. По-перше, нагромаджена база даних щодо кількісних значень сконструйованих показників дає підстави для об'єктивного оцінювання переваг та обмежень підходу. По-друге, використовувані показники мають достатньо зрозумілий зміст, який може інтерпретуватися як макрофінансовий.

Для обгрунтування змін в інституційному дизайні макрофінансової безпеки важливим $\epsilon$ й аналіз досвіду країн поза межами ЄС. Насамперед для нас важливе українське застосування поняття «макрофінансове». 3 аналізу нормативно-правової бази передовсім випливають такі узагальнення.

По-перше, термін «макрофінансове» відсутній у законах України, але використовується органами державної влади в документах нижчого (ніж закони) рівня. Найбільш активним користувачем цього терміна виявляється Національний банк України (НБУ). В сучасних документах НБУ термін «макрофінансове» використовується у таких контекстах:

- «мінімізація загроз макрофінансової стабільності» [8];

- «посилення загроз для макрофінансової стабільності» [9];

- «забезпечення макрофінансової стабільності» [10].

Аналіз змісту згаданих документів НБУ дає підстави для висновку про таке загальне тлумачення «макрофінансової стабільності». Це те, що залежить від:

- постійності наповнення бюджету й пов'язаної з дефіцитом бюджету інфляції;

- виконання програм співпраці з МВФ;

- економічного зростання;

- узгодженості дій НБУ, Міністерства фінансів України та інших пов' язаних з ними інститутів.

У постановах іншого інституту - Верховної Ради України (ВРУ) термін «макрофінансове» використовується, зокрема, в таких контекстах:

- «умови для макрофінансової стабілізації» [11];

- додаткова макрофінансова допомога [12].

3 аналізу змісту згаданих документів (постанов ВРУ) виплаває тлумачення терміна «макрофінансове» як явища, що пов'язане 3 інвестиціями, переважно іноземними, та явища, що суттєво залежить від допомоги міжнародних фінансових організацій.

3 аналізу документів НБУ випливає й достатньо скептичне ставлення до можливості оцінювання стабільності. Зокрема, цей скепсис виявляється при згадуванні «макропруденційної політики, метою якої $€$ забезпечення фінансової стабільності» [13]. У публікації головного 
експерта Департаменту фінансової стабільності [14], розміщеної на сайті Експертної платформи - об’єднання співробітників НБУ констатується, що немає універсальних показників вимірювання й можна використовувати серію показників, об'єднаних в інтегральні індекси. Останні створюють можливість оцінювання поточного стану, але, як фіксує автор документа, не дають можливість передбачати.

Ми, натомість, вважаємо доцільним, 3 наукової та прикладної позицій, пошук саме в царині способів оцінювання макрофінансової безпеки, який би спирався на обгрунтоване тлумачення терміна «макрофінансове».

Більш конкретизоване тлумачення аналізованого нами терміна, 3 боку інститутів публічної влади - стейкхолдерів української економічної політики - на наш погляд, можна віднайти в офіційних методиках оцінювання. Такою, зокрема, $є$ чинна методика оцінювання рівня економічної безпеки, затверджена 2013 р. Міністерством економічного розвитку і торгівлі України [15].

Згадана методика не містить власне поняття «макрофінансове», але в ній подано розгорнуте й конкретизоване тлумачення «макроекономічного» та «фінансового». Стислий перелік показників подано в аналітичній табл. 2.

Таблиия 2

Показники для оцінювання макроекономічної та фінансової безпеки, за чинною в Україні офіційною методикою 2013 р.

\begin{tabular}{|c|c|}
\hline Показники & \begin{tabular}{|c|} 
Кількість \\
показників
\end{tabular} \\
\hline \multicolumn{2}{|l|}{ Макроекономічна безпека } \\
\hline Різниця між значеннями індексу продуктивності праці та заробітної & \\
\hline & 1 \\
\hline Рівень тінізації економіки (\% ВВП) & 1 \\
\hline Сальдо поточного рахунку платіжного балансу (\% ВВП) & 1 \\
\hline Рівень безробіття, за методологією МОП (\%) & 1 \\
\hline $\begin{array}{l}\text { Рівень тривалості безробіття - частка безробітних більше } 12 \\
\text { місяців (\%) }\end{array}$ & 1 \\
\hline $\begin{array}{l}\text { Різниця між темпом економічного зростання країни та відповідним } \\
\text { середнім показником для країн, що розвиваються (в. п.) }\end{array}$ & 1 \\
\hline Індекс споживчих цін (грудень до грудня) (разів) & 1 \\
\hline Наявний дохід населення у ВВП (\%) & 1 \\
\hline Схильність до заощаджень (\%) & 1 \\
\hline $\begin{array}{l}\text { Співвідношення між середньою зарплатою та всіма видами } \\
\text { допомоги і сочіальних трансфертів (разів) }\end{array}$ & 1 \\
\hline $\begin{array}{l}\text { Співвідношення між ВВП на душу населення в Україні та в } \\
\text { крайнах } С С(\%)\end{array}$ & 1 \\
\hline Зайнятість населення в неформальному секторі економіки (\%) & 1 \\
\hline Разом & 12 \\
\hline
\end{tabular}


Продовження табл. 2

\begin{tabular}{|l|c|}
\hline Фінансова безпека & 7 \\
\hline Група показників банківської безпеки & 4 \\
Група показників небанківського фінансового ринку & 5 \\
Група показників боргової безпеки & 4 \\
Група показників бюджетної безпеки & 6 \\
Група показників валютної безпеки & 6 \\
Група показників грошово-кредитної безпеки & $\mathbf{3 2}$ \\
\hline Разом & $\mathbf{4 4}$ \\
\hline Всього & \\
\hline
\end{tabular}

Джерело: розроблено авторами самостійно на основі офіційних методичних рекомендацій щзодо розрахунку рівня економічної безпеки України від 2013 р.

Подані в табл. 2 показники є своєрідним чинним «українським табло» для визначення рівня макроекономічної та фінансової безпеки, подібним до табло країн ЄС. Власне факт наявності переліку таких показників та достатньо зрозумілі алгоритми розрахунків, на наш погляд, $є$ значним здобутком української системи публічного управління. Компаративний аналіз «українського табло» на тлі табло країн ЄС дає підстави для таких узагальнень:

- частина показників, що ідентифіковані в українській методиці оцінювання як макроекономічні, мають, переважно, соціальноекономічне «навантаження», оскільки стосуються стану соціальної сфери. Вони віддзеркалюють не стільки власне макроекономічні пропорції, скільки пропорції у соціальній сфері. Це, зокрема, стосується показників: перерозподілу доходів через податки, внеску різних видів соціальної допомоги та трансфертів у сукупні доходи, порівняльного (відносного) добробуту громадян. Ідеться про такі показники з переліку показників української методики оцінювання (табл. 2), як: частка наявного (після оподаткування) доходу населення у ВВП; співвідношення між середньою зарплатою та всіма видами допомог і соціальних трансфертів; міра наближення ВВП на душу населення в Україні до показників СС (\%); частка зайнятого населення в неформальному секторі економіки;

- рівень деталізації показників фінансової сфери (їх кількість становить 32) може вважатися надмірним. Поділ фінансових показників на 6 груп передбачає розрахунок 6 субіндексів: банківської, небанківських фінансових посередників, боргової, бюджетної, валютної, грошовокредитної безпеки. Це значно ускладнює оцінювання цієї сфери та інтерпретацію результатів, а також прийняття на основі цієї інтерпретації управлінських рішень.

Попри зазначені особливості, так зване «українське табло» в його чинному тлумаченні, є достатньо прикладним. Тривале застосування 
впродовж багатьох років (методика 2013 р. спиралася на подібну методику 2007 р. [16]) створило значну інформаційну базу. Чинна методика, на наш погляд, придатна не лише для оцінювання поточного стану та обгрунтування поточних рішень, а й для передбачень та обгрунтування управлінських рішень для майбутнього.

Скористаймося для аналізу даними розрахунку, за «українським табло», інтегрального показника (індексу) національної економічної безпеки та двох показників (субіндексів) макроекономічної і фінансової безпеки (табл. 3).

Таблиия 3

Динаміка показників рівня безпеки, за українськими даними згідно з офіційною методикою 2013 р., за період 2007 - 2018 рр. (\%)

\begin{tabular}{|l|c|c|c|c|c|c|c|c|c|c|c|c|}
\hline $\begin{array}{c}\text { Показники } \\
\text { безпеки }\end{array}$ & $\mathbf{2 0 0 7}$ & $\mathbf{2 0 0 8}$ & $\mathbf{2 0 0 9}$ & $\mathbf{2 0 1 0}$ & $\mathbf{2 0 1 1}$ & $\mathbf{2 0 1 2}$ & $\mathbf{2 0 1 3}$ & $\mathbf{2 0 1 4}$ & $\mathbf{2 0 1 5}$ & $\mathbf{2 0 1 6}$ & $\mathbf{2 0 1 7}$ & $\mathbf{2 0 1 8}$ \\
\hline макроекономічної & 48 & 38 & 44 & 38 & 48 & 38 & 39 & 32 & 31 & 35 & 37 & 41 \\
\hline фінансової & 64 & 51 & 42 & 44 & 47 & 46 & 50 & 38 & 36 & 40 & 42 & 46 \\
\hline $\begin{array}{l}\text { загальної } \\
\text { економічної }\end{array}$ & 52 & 48 & 46 & 47 & 50 & 46 & 48 & 45 & 44 & 48 & 48 & 50 \\
\hline
\end{tabular}

Джерело: складено авторами на основі [17].

У таблиці репрезентовано показники рівня 3 безпек: загальної економічної та іiі складників - макроекономічної й фінансової. Показники рівня безпеки оцінено із застосуванням статистичного інструментарію інтегральних індексів за алгоритмом, визначеним у методиці, затвердженій Міністерством економічного розвитку та торгівлі у 2013 р.

У відповідності з загальними статистичними правилами побудови інтегральних індексів, у розрахунках використано процедури нормування показників та застосування вагових коєфіцієнтів. Фактично, йдеться про типову формулу для інтегральних індексів:

$$
I_{S}=\sum_{i=1}^{m} k_{m} n_{m},
$$

де $I_{S}$ - інтегральний індекс, у нашому випадку - індекс безпеки, який формується $3 m$ показників; $k_{m}$ - вагові коєфіцієнти змінних (показників), що використовуються для визначення індексу; $n_{m}$ - нормовані значення змінних (показників), що використовуються в розрахунках індексу.

Для кращої візуалізації дані табл. 3 подано нами на рис. 1, який, окрім фактичних значень показників (індексів) рівня безпеки, віддзеркалює ще й п'ять зон безпечності: критичну, небезпечну, незадовільну, задовільну, оптимальну зони. 


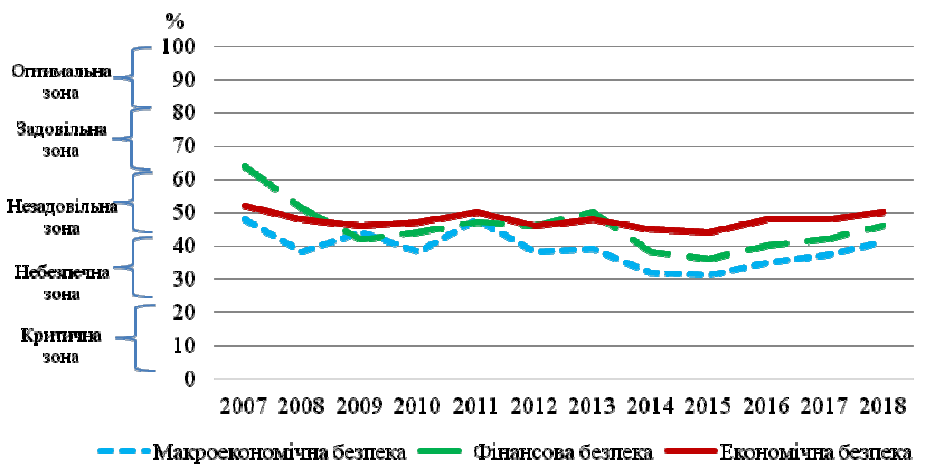

Рис. 1. Динаміка показників загальної економічної, макроекономічної та фінансової безпеки в межах зон безпечності у $2007-2018$ pp.

Джерело: створено самостійно на основі інформачиї з табл. 3.

Аналіз інформації, поданої на рис. 1, дає підстави для таких узагальнень:

- упродовж аналізованого періоду всі показники - загальної економічної, макроекономічної та фінансової безпеки - здебільшого перебували в зоні незадовільного стану. Виняток становить лише показник фінансової безпеки у 2007 р., що потрапляв у зону задовільного стану, та показники фінансової і макроекономічної безпеки, які в початковий період російсько-української війни 2014 2017 рр. перебували у зоні небезпечного стану;

- рівні макроекономічної та фінансової безпеки за всі 12 досліджуваних років були нижчими, ніж рівень загальної економічної безпеки, оцінюваної з використанням інтегрального індексу 3 ще 7 субіндексами, передбаченими методикою 2013 р., а саме: демографічної, соціальної, продовольчої, виробничої, енергетичної, зовнішньоекономічної та інвестиційно-інноваційної безпеки;

- рівень макроекономічної безпеки зазвичай був нижчим за рівень фінансової безпеки.

Якщо припускати, що інформація, подана на рис. 1, є об’ єктивною й релевантною, то 3 неї випливають принаймні такі передбачення (прогностичні висновки):

- показники рівня макроекономічної та фінансової безпеки мають бути більшою мірою в центрі уваги - моніторингу, аналізу, публічного обговорення, застосування інструментів впливу - національних регуляторів, ніж інші складники безпеки;

- за умов фактичного абсолютного спаду української економіки у 2019 - 2020 рр., показники макроекономічної та фінансової безпеки 
можуть зменшитися до рівня, який спостерігався у 2015 р. Саме у цей рік відбувався найглибший економічний спад у досліджуваному періоді.

Наш проміжний висновок щодо уточнення змісту поняття «макрофінансова стабільність (безпека)» для формування відповідного інституційного дизайну втілюється у такому тлумаченні поняття «макрофінансове». «Макрофінансове» - це поєднання макроекономічного (пов'язаного передовсім з рухом матеріальних активів) та фінансового (пов'язаного 3 національними фінансовими активами). Критерієм органічності такого поєднання є відповідність, за якої стан фінансової сфери не створює загроз для реального сектору економіки, а стан реального сектору - загроз для фінансової сфери.

Спираючись на досвід використання Табло країн ЄС та практику оцінювання економічної безпеки в Україні, ми припускаємо можливість створення оновленого «українського табло». Ймовірно, що саме навколо нього міг би формуватися український дизайн макрофінансової безпеки. Якщо виходити 3 доцільності визначення обмеженого кола 3 10-х показників, то вони, на наш погляд, могли би бути такими:

1. Річне сальдо рахунку поточних операцій платіжного балансу (у \% до ВВП).

2. Річна зміна реального обмінного курсу (в. п.).

3. Річний темп інфляції (\%).

4. Достатність офіційних валютних резервів (у місяцях імпорту).

5. Чиста міжнародна інвестиційна позиція (у \% до ВВП).

6. Державний борг (у \% до ВВП).

7. Відношення обсягу сукупних платежів з обслуговування та погашення державного боргу до доходів державного бюджету, відсотків (\%).

8. Рівень безробіття, за методологією МОП (\%).

9. Співвідношення між індексом продуктивності праці та індексом реальної заробітної плати (разів). ВВП).

10. Рівень тінізації економіки (частка тіньової економіки у \%

Пропонований перелік показників так званого «українського табло» $є$ скороченим порівняно 3 переліком, що охоплює десятки показників, передбаченим чинною українською методикою оцінювання макроекономічної та фінансової безпеки.

Перелік показників пропонованого «скороченого українського табло» для оцінювання рівня макрофінансової безпеки має такі особливості, спричинені особливостями поточного стану української економіки і суспільства: 
- містить 7 відносних показників стану національних фінансових активів та 3 показники (безробіття, співвідношення змін загальної продуктивності праці й зарплати, частки тіньової економіки), які характеризують стан реального сектору. Значна частка від загальної кількості показників (30\%), що безпосередньо стосуються стану реального сектору, може пояснюватися перманентним і тривалим перебуванням української економіки в спадній частині реального економічного циклу. Відтак, зростає вага таких показників, як зайнятість ресурсів, продуктивність, частка економіки в тіні;

- передбачає використання річних (а не середніх за певний період, як у Табло (С) показників, з огляду на значну економічну волатильність, відсутність достатньо тривалих періодів стабільної динаміки. Відтак, об'єктивно необхідним стає моніторинг і контроль короткотермінових (річних) змін;

- складається з обмеженого кола показників для спрощення процедури ідентифікації функцій та розподілу повноважень між органами публічної влади у межах інституційного дизайну. Адже формування дизайну публічного управління об' єктивно ускладняється за більшого переліку показників.

У контексті досліджуваної нами проблеми після окреслення того, навколо яких процесів, явищ, відповідно, показників має формуватися інституційний дизайн, важливо уточнити власне зміст поняття інституційного дизайну. Сучасна політична наука пропонує багато підходів до його тлумачення. Зупинимося лише на декількох, а саме тих, які, на наш погляд, можуть мати найбільше практичне застосування.

У книзі Robert E. Goodin, присвяченій теорії інституційного дизайну [18], останній потрактовано як дієву форму просування ціннісних результатів у конкретному контексті. Практичність цього акценту у визначенні змісту інституційного дизайну, на наш погляд, пов'язана з визнанням важливості усвідомлення об'єктивних цінностей суспільства та творення ефективної форми їх реалізації.

Josep M. Colomer [19] визначає інституційний дизайн як «вибір правил для прийняття колективних рішень». Акцентується на тому, що інститути можуть створювати обмеження для колективних рішень i тому зменшують невизначеність. Натомість, дизайн, за авторським уявленням, покликаний створювати гармонійне середовище для взаємодії у суспільстві.

У книзі David L. Weimer [20], присвяченій інституційному дизайну, 3 огляду на проблеми реалізації державної політики, інституційний дизайн визначається як відносно стійкий набір взаємопов'язаних правил та стимулів, що формують узгоджені процедури, призначені для досягнення предметних цілей. 
Серед визначень інституційного дизайну, пропонованих українськими дослідниками, важливими для нашого дослідження $€$ принаймні такі:

- «цілеспрямоване компонування інститутів з метою упорядкування правил, що регулюють взаємовідносини між людьми у передбачуваному напрямку з метою відповідності існуючим потребам і змінам» [21];

- «динамічний процес трансформаційних змін існуючих традиційних інститутів у стан нових» [22].

Практична цінність двох останніх визначень від українських дослідників пояснюється акцентуванням на необхідності зміни форм та правил остільки, оскільки змінюються потреби користувачів дизайну. Фактично, йдеться про динамічний підхід до визначення змісту інституційного дизайну.

Чинне законодавство України не містить визначення терміна «дизайн» ні у загальному сенсі, ні в сенсі дизайну для національної макрофінансової безпеки. Але в ньому використовується поняття «дизайну продукту». Це - «сукупність процесів, які перетворюють правові, технічні, функціональні, ринкові вимоги, вимоги щодо безпеки чи інші вимоги, яким повинен відповідати продукт, у технічну специфікацію на такий продукт» [23]. Практична спрямованість цього визначення полягає у тому, що ним визнається необхідність відповідності між дизайном та об'єктивними вимогами, включно з безпековими, та те, що дизайн передбачає певні нормативи (специфікації).

3 огляду на все зазначене, надалі в якості робочої гіпотези ми користуватимемося таким визначенням: «Інституційний дизайн $\epsilon$ формою реалізачіі спроєктованих процедур, алгоритмів взаємодії, правил, стимулів та обмежень, які забезпечують иіннісні орієнтири суспільства (громад) у певних сферах». Зрозуміло, що інституційний дизайн у публічній сфері, якою і є сфера національної економічної безпеки, має спиратися на інститути влади, у взаєминах між якими та між якими й суспільством існує унормований розподіл повноважень та відповідальності.

Узагальнення щодо доцільності або, навпаки, недоцільності певного інституційного дизайну макрофінансової безпеки можуть на даний час спиратися на аналіз діяльності інститутів ЄС. Ідеться передусім про вже згадувану нами процедуру макроекономічних дисбалансів (The Macroeconomic Imbalance Procedure - MIP) та пов' язані з нею документи і практики регулювання [23-32].

Основні взаємини у формуванні інституційного дизайну макрофінансової безпеки, за нормативними документами СС, складаються між такими інститутами цього утворення:

- Свропейська Комісія (European Commssion);

- Свропейська Рада (European Council); 
- Рада СC (Council of the EU (Council));

- країни-учасниці (Member States);

- Свропейський Парламент (European Parliament).

Інституційний дизайн макрофінансової безпеки ЄС є достатньо складним. Гранично спрощено він поданий нами у вигляді так званої «матриці взаємодії інститутів ЄС». Причому йдеться про два етапи загальної процедури, а саме виявлення дисбалансів та реагування (дії після діагностування надмірних дисбалансів). Ці два етапи, відповідно, дві матриці взаємодії репрезентовано у табл. 4 та табл. 5.

Таблиия 4

\section{Матриця спеціальних функцій інститутів СС щодо виявлення макрофінансових дисбалансів}

\begin{tabular}{|c|c|c|c|c|}
\hline $\begin{array}{l}\text { Свропейська Комісія } \\
\text { (European Commssion) }\end{array}$ & $\begin{array}{c}\text { Європейська } \\
\text { Рада } \\
\text { (European } \\
\text { Council) }\end{array}$ & $\begin{array}{c}\text { Рада } \mathrm{EC} \\
\text { (Council of the } \\
\text { EU (Council)) }\end{array}$ & $\begin{array}{c}\text { Крани-члени СС } \\
\text { (Member States) }\end{array}$ & $\begin{array}{c}\text { Свропейський } \\
\text { Парламент } \\
\text { (European } \\
\text { Parliament) }\end{array}$ \\
\hline 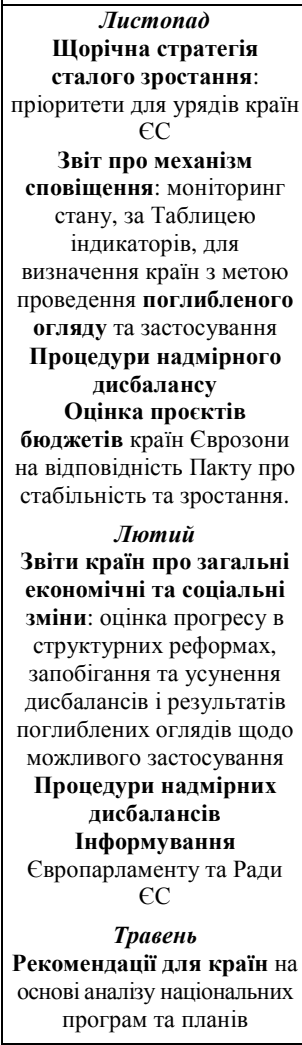 & $\begin{array}{c}\text { Листопад } \\
\text { Організація } \\
\text { дискусії щодо } \\
\text { Щорічної } \\
\text { стратегії сталого } \\
\text { зростання та } \\
\text { Звіту про } \\
\text { механізм } \\
\text { оповіщення для } \\
\text { координації } \\
\text { економічних } \\
\text { політик країн } \\
\text { ЄС } \\
\text { Березень } \\
\text { Вказівки щодо } \\
\text { пріоритетів } \\
\text { національних } \\
\text { реформ у } \\
\text { програмах та } \\
\text { бюджетних } \\
\text { планах. } \\
\text { Червень-липень } \\
\text { Затвердження } \\
\text { остаточних } \\
\text { Рекомендацій } \\
\text { для кожної } \\
\text { країни }\end{array}$ & \begin{tabular}{|c|} 
Листопад \\
Участь у \\
дискусії про \\
Щорічну \\
стратегію \\
сталого \\
зростання \\
Обговорення \\
оцінки \\
Єврокомісії \\
щодо проєктів \\
бюджетів країн \\
Єврозони \\
Грудень-січень \\
Схвалює \\
Рекомендації \\
для Єврозони \\
на основі \\
листопадових \\
обговорень \\
документів \\
ЄС, Щорічну \\
стратегію \\
сталого \\
розвитку та \\
Звіт про \\
механізм \\
оповіщення \\
Червень- \\
липень Участь \\
в обговоренні \\
впровадження \\
Рекомендацій \\
для Єврозони в \\
окремих \\
країнах ЄС
\end{tabular} & $\begin{array}{c}\text { Жовтень } \\
\text { Проєкти } \\
\text { бюджетів на } \\
\text { наступний рік } \\
\text { Участь у } \\
\text { двосторонніх } \\
\text { перемовинах } 3 \\
\text { Єврокомісією } 3 \\
\text { бюджетних питань } \\
\text { та пріоритетів } \\
\text { розвитку } \\
\text { Грудень } \\
\text { Ухвалення } \\
\text { бюджетних планів } \\
\text { Квітень } \\
\text { Національні } \\
\text { програми реформ } \\
\text { та стабільності / } \\
\text { конвергенцї, з } \\
\text { визначенням } \\
\text { шляхів } \\
\text { запобігання / } \\
\text { виправлення } \\
\text { дисбалансів, } \\
\text { дотримання } \\
\text { фіскальних правил } \\
\text { та пріоритетів } \\
\text { розвитку } \\
\text { Серпень-вересень } \\
\text { Імплементація } \\
\text { визнаних } \\
\text { інститутами ЄС } \\
\text { Рекомендацій у } \\
\text { національне } \\
\text { законодавство та } \\
\text { щорічні бюджети }\end{array}$ & $\begin{array}{c}\text { Листопад } \\
\text { Організація } \\
\text { дискусії щодо } \\
\text { пріоритетів, } \\
\text { окреслених у } \\
\text { Щорічній } \\
\text { стратегї̈ } \\
\text { сталого } \\
\text { зростання } \\
\text { Участь в } \\
\text { обговоренні } \\
\text { Звіту про } \\
\text { механізм } \\
\text { сповіщення } \\
\text { Лютий } \\
\text { Приймає } \\
\text { Щорічну } \\
\text { стратегію } \\
\text { сталого } \\
\text { розвитку та Звіт } \\
\text { про механізм } \\
\text { оповіщення } \\
\text { Травень } \\
\text { Дискусія щодо } \\
\text { опублікованих } \\
\text { Єврокомісією } \\
\text { Рекомендацій } \\
\text { для країн- } \\
\text { членів ЄС }\end{array}$ \\
\hline
\end{tabular}

Джерело: створено авторами самостійно. 
Реалізація функцій інститутів СС, репрезентованих в аналітичній табл. 4, завершується встановленням факту надмірних дисбалансів. Подальші дії інститутів спрямовані безпосередньо на коригування ситуації (табл. 5).

Табличя 5

Матриця спеціальних функцій інститутів ЄС, які реалізуються після виявлення надмірних макрофінансових дисбалансів

\begin{tabular}{|c|c|c|c|c|}
\hline $\begin{array}{l}\text { Свропейська } \\
\text { Комісія } \\
\text { (European } \\
\text { Commssion) }\end{array}$ & $\begin{array}{c}\text { Європейська } \\
\text { Рада } \\
\text { (European } \\
\text { Council) }\end{array}$ & $\begin{array}{c}\text { Рада } \mathrm{EC} \mathrm{(Council} \\
\text { of the EU } \\
\text { (Council)) }\end{array}$ & $\begin{array}{c}\text { Крани-члени СС } \\
\text { (Member States) }\end{array}$ & $\begin{array}{c}\text { Європейський } \\
\text { Парламент } \\
\text { (European } \\
\text { Parliament) }\end{array}$ \\
\hline $\begin{array}{c}\text { Червень } \\
\text { Рішення про } \\
\text { початок } \\
\text { Процедури } \\
\text { обмеження } \\
\text { надмірних } \\
\text { дисбалансів, } \\
\text { інформування } \\
\text { інших } \\
\text { інститутів ЄС } \\
\text { про системні } \\
\text { ризики та } \\
\text { Звіт про } \\
\text { прийнятність } \\
\text { Плану дій } \\
\text { Рекомендації } \\
\text { щодо } \\
\text { застосування } \\
\text { санкцій, їх } \\
\text { планової або } \\
\text { дострокової } \\
\text { відміни }\end{array}$ & & $\begin{array}{c}\text { Червень } \\
\text { Рекомендації } \\
\text { країнам щодо } \\
\text { заходів для } \\
\text { Плану } \\
\text { коригуючих дій } \\
\text { Рекомендації } 3 \\
\text { усунення } \\
\text { надмірних } \\
\text { дисбалансів у разі } \\
\text { прийнятності } \\
\text { Плану та } \\
\text { Рекомендації } \\
\text { щодо змін Плану } \\
\text { коригувальних } \\
\text { дій, за } \\
\text { висновками } \\
\text { наглядових місій } \\
\text { Рішення про } \\
\text { застосування } \\
\text { санкцій до країн } \\
\text { та про їх відміну }\end{array}$ & $\begin{array}{c}\text { Червень } \\
\text { Розробка Планів } \\
\text { конкретних дії з } \\
\text { термінами } \\
\text { виконання та їх } \\
\text { подання для аналізу } \\
\text { Єврокомісії } \\
\text { Розробка } \\
\text { оновлених Планів } \\
\text { коригуючих дій (за } \\
\text { потреби) } \\
\text { Виконання } \\
\text { санкцій у разі } \\
\text { визнання Радою } \\
\text { неприйнятності } \\
\text { Планів або їх } \\
\text { недотримання } \\
\text { країною Єврозони. } \\
\text { Звітування перед } \\
\text { Єврокомісією та } \\
\text { Радою про прогрес } \\
\text { у подоланні } \\
\text { дисбалансів }\end{array}$ & \\
\hline
\end{tabular}

Джерело: створено авторами самостійно.

3 аналізу інформації, поданої у таблицях, можна зробити такі узагальнення щодо змісту інституційного дизайну макрофінансової безпеки $\mathrm{CC}$ :

1. Інструментами впливу на ситуацію з боку основних інститутів $€ \mathrm{C}$, через які підтримується макрофінансова стабільність (безпека), можуть ставати:

- загальна стратегія розвитку з окресленням пріоритетів;

- загальні правила, репрезентовані передусім певними макрофінансовими показниками;

- перманентний моніторинг подій та оцінювання ризиків;

- публічне обговорення результатів моніторингу; 
- аналіз національних програм та результатів розвитку країн для визначення відхилень (дисбалансів);

- офіційні рекомендації щодо планів коригуючих дій з обмеження дисбалансів, виявлених у процесі моніторингу;

- звіти за результатами виконання затверджених планів коригуючих дій;

- визначення, застосування та відміна санкцій щодо країнпорушниць встановлених правил.

2. Інституційний дизайн передбачає чітко розподілені повноваження та відповідальність інститутів влади. Інститути залучаються до окремих етапів процедури обмеження дисбалансів, лише виходячи з призначення (цілей, повноважень) кожного з них. Тому, два 3 п'ятьох інститутів СС Європейська Рада (European Council) та Європейський Парламент (European Parliament) - не беруть безпосередньої участі в реалізації завершального етапу застосування санкцій для усунення дисбалансів.

3. Застосування інструментів регулювання дисбалансів чітко фіксоване та узгоджене у часі впродовж кожного року. Відтак, дотримання часових меж постає важливим правилом регулювання дисбалансів.

Для обгрунтування пропозицій щодо формування інституційного дизайну макрофінансової безпеки в Україні, зокрема в частині застосування досвіду ЄС, необхідно об'єктивно оцінити існуючий дизайн. Ідеться передусім про фіксацію надбань та проблем в організації системи публічного управління станом безпеки.

До основних надбань у формуванні українського інституційного дизайну, на наш погляд, належить таке:

- існування офіційних методик оцінювання рівня економічної безпеки, розроблених за ініціативи Міністерства економічного розвитку України у 2007 р. та у 2013 р., та доступність джерел первинної інформації для розрахунків і офіційних результатів розрахунків;

- створення проєктів двох Указів Президента України 2015 р. та 2018 р., у яких закладалося підгрунтя для більш чіткого окреслення змісту діяльності владних інститутів, розмежування їх функцій та відповідальності щодо формування інформаційної бази, моніторингу, публікування результатів і планів заходів [33].

До основних недоліків (обмежень) у формуванні українського інституційного дизайну макрофінансової безпеки, на наш погляд, належить таке:

- відсутність запобіжників щодо припинення оприлюднення результатів розрахунків показників рівнів економічної безпеки у вільному доступі й перехід до обмеженої доступності інформації у формі офіційних запитів до відповідного міністерства; 
- ускладнення власних розрахунків, за офіційною методикою, через частковий брак офіційної інформації;

- дискретність (непослідовність) процесів формування дизайну, зокрема, через незатвердження проєктів двох згаданих (2015 та 2018 років) Указів Президента України, які спрямовували на створення основи унормування взаємодії органів державної влади в гарантуванні економічної (макрофінансової) безпеки.

Окремі фрагменти потенційного інституційного дизайну макрофінансової безпеки можемо віднайти в законодавстві щодо діяльності окремих інститутів української влади. Вони навряд чи можуть бути потрактовані власне як елементи сформованого дизайну макрофінансової безпеки через те, що вмонтовані в інші алгоритми. Зокрема, йдеться про алгоритм прийняття щорічного державного бюджету або алгоритм контролю за борговими показниками. Деякі фрагменти, які можуть скласти основу майбутнього інституційного дизайну макрофінансової безпеки, подано в Матриці спеціальних функцій (табл. 6).

Таблиия 6

Матриця спеціальних функцій інститутів української публічної влади, потенційно дотичних до макрофінансової безпеки

\begin{tabular}{|c|c|}
\hline $\begin{array}{l}\text { Інститути публічної } \\
\text { влади України }\end{array}$ & $\begin{array}{c}\text { Функції, дотичні до регулювання макрофінансових } \\
\text { дисбалансів }\end{array}$ \\
\hline $\begin{array}{l}\text { Верховна Рада } \\
\text { України (включно } 3 \\
\text { профільними } \\
\text { комітетами) (ВРУ) }\end{array}$ & $\begin{array}{l}\text { 1. Бере участь у підготовці пропозицій до щорічного } \\
\text { бюджетного плану. } \\
\text { 2. До 01.12.: ухвалює бюджет на наступний рік. } \\
\text { 3. До 15.07.: розглядає Бюджетну Декларацію. } \\
\text { 4. Ухвалює зміни впродовж року до бюджету. }\end{array}$ \\
\hline $\begin{array}{l}\text { Кабінет Міністрів } \\
\text { України (КМУ) }\end{array}$ & $\begin{array}{l}\text { 1. До 15.09.: схвалює проєкт державного бюджету та } \\
\text { подання його ВРУ та Президенту } 3 \text { урахуванням } \\
\text { лімітних вимог Бюджетного Кодексу. } \\
\text { 2. До 01.06.: схвалює Бюджетну Декларацію (прогнози } \\
\text { місцевих бюджетів). } \\
\text { 3. Затверджує Середньорічну стратегію управління } \\
\text { державним боргом. }\end{array}$ \\
\hline Президент України & $\begin{array}{l}\text { До 15.12.: може подати пропозиції до схваленого } \\
\text { проєкту бюджету. }\end{array}$ \\
\hline $\begin{array}{l}\text { Міністерство } \\
\text { фiнансів України } \\
\text { (Мінфін) }\end{array}$ & $\begin{array}{l}\text { 1. Складає проєкт державного бюджету та вносить } \\
\text { пропозиції щодо термінів і порядку його розгляду. } \\
\text { 2. До } 15.05 .: \text { подає на розгляд КМУ Бюджетну декларацію } \\
\text { (прогноз місцевих бюджетів) на наступні два періоди. } \\
\text { 3. Розробляє Середньорічну стратегію управління } \\
\text { державним боргом. } \\
\text { 4. Здійснює моніторинг та аналіз реалізації стратегії, } \\
\text { визначає пріоритети. }\end{array}$ \\
\hline
\end{tabular}


Продовження табл. 6

\begin{tabular}{|c|c|}
\hline & $\begin{array}{l}\text { 5. Формулює рекомендації (без термінів, конкретизації } \\
\text { виконавців). }\end{array}$ \\
\hline $\begin{array}{l}\text { Боргове агентство } \\
\text { України }\end{array}$ & $\begin{array}{l}\text { Реалізує політику в сфері управління } \text { боргом } 3 \\
\text { урахуванням середньострокової стратегії управління } \\
\text { державним боргом та умов дотримання граничного } \\
\text { обсягу державного боргу на кінець бюджетного періоду. }\end{array}$ \\
\hline $\begin{array}{l}\text { Національний банк } \\
\text { України (НБУ) }\end{array}$ & $\begin{array}{l}\text { 1. До 01.03: розробляє та подає макроекономічний } \\
\text { прогноз до Мінфіну для узгодження бюджетної політики. } \\
\text { 2. У межах своїх повноважень здійснює аналіз стану } \\
\text { фінансової системи. } \\
\text { 3. Розробляє та публікує щорічний Звіт про фінансову } \\
\text { стабільність. }\end{array}$ \\
\hline $\begin{array}{l}\text { Рада національної } \\
\text { безпеки та оборони } \\
\text { України (РНБО) }\end{array}$ & $\begin{array}{l}\text { 1. До 15.04.: на підставі обсягу видатків та надання } \\
\text { кредитів на національну безпеку і оборону на } \\
\text { середньостроковий період готує та надає Мінфіну } \\
\text { обгрунтовані пропозиції щодо іх розподілу між } \\
\text { головними розпорядниками коштів державного бюджету. } \\
\text { 2. Готує пропозиції до проєкту Закону про Державний } \\
\text { бюджет України до його схвалення КМУ за статтями, } \\
\text { пов'язаними із забезпеченням національної безпеки і } \\
\text { оборони України (з вмотивованим обгрунтуванням). }\end{array}$ \\
\hline \begin{tabular}{l|} 
Міністерство \\
економічного \\
розвитку України \\
(Мінекономрозвитку)
\end{tabular} & $\begin{array}{l}\text { 1. До 01.03: розробляє та подає макроекономічний } \\
\text { прогноз до Мінфіну для узгодження бюджетної політики } \\
\text { на наступні періоди. } \\
\text { 2. Розробляє механізм забезпечення економічної безпеки } \\
\text { держави. Двічі на рік здійснює розрахунок рівня } \\
\text { економічної безпеки, але не публікує його у вільному } \\
\text { доступі. }\end{array}$ \\
\hline $\begin{array}{l}\text { Рада з фінансової } \\
\text { стабільності України }\end{array}$ & $\begin{array}{l}\text { Виявляє загрози для фінансової стабільності та розробляє } \\
\text { рекомендації. }\end{array}$ \\
\hline $\begin{array}{l}\text { Міністерство } \\
\text { соціальної політики } \\
\text { України } \\
\text { (Мінсоцполітики) }\end{array}$ & $\begin{array}{l}\text { До 01.03.: Розробляє та подає прогноз соціальних } \\
\text { показників до Мінфіну для узгодження бюджетної } \\
\text { політики на наступні періоди. }\end{array}$ \\
\hline
\end{tabular}

Джерело: складено авторами самостійно на основі [34].

3 аналізу інформації, репрезентованої у формі аналітичної табл. 6, можна зробити висновок про брак часової та змістової узгодженості дій між окремими інститутами публічної влади. Це власне й дає підстави для висновку про відсутність цілісності у формуванні дизайну економічної безпеки. Так само не йдеться про цілісність інституційного дизайну макрофінансової безпеки, або безпеки, сформованої навколо так званого «українського табло».

3 огляду на все зазначене 3 приводу змісту поняття (явища) «макрофінансова безпека», табло показників для іiї оцінювання, а 
також зазначене 3 приводу інституційного дизайну загалом та його чинного українського втілення, доходимо висновку про обгрунтованість такого підходу до українського інституційного дизайну (рис. 1).

\begin{tabular}{|c|c|c|c|}
\hline $\begin{array}{c}\text { Зміст: «українське } \\
\text { табло» }\end{array}$ & Інститути & \multicolumn{2}{|c|}{$\begin{array}{c}\text { Процедури: інструменти, } \\
\text { терміни }\end{array}$} \\
\hline $\begin{array}{l}\text { 1. Річне сальдо рахунку } \\
\text { поточних операцій } \\
\text { платіжного балансу (у \% до } \\
\text { ВВП) } \\
\text { 2. Річна зміна реального } \\
\text { обмінного курсу (в.п.) } \\
\text { 3.Річний темп інфляції (\%) } \\
\text { 4. Достатність офіційних } \\
\text { валютних резервів (у } \\
\text { місяцях імпорту) } \\
\text { 5. Чиста міжнародна } \\
\text { інвестиційна позиція (у \% } \\
\text { до ВВП) } \\
\text { 6. Державний борг (у \% до } \\
\text { ВВП) } \\
\text { 7. Відношення обсягу } \\
\text { сукупних платежів } 3 \\
\text { обслуговування та } \\
\text { погашення державного } \\
\text { боргу до доходів } \\
\text { державного бюджету, } \\
\text { відсотків (\%) } \\
\text { 8. Рівень безробіття, за } \\
\text { методологією МОП (\%) } \\
\text { 9. Співвідношення між } \\
\text { індексом продуктивності та } \\
\text { індексом реальної зарплати } \\
\text { (разів) } \\
\text { 10. Рівень тінізації } \\
\text { економіки (частка тіньової } \\
\text { економіки у \% ВВП) }\end{array}$ & $\begin{array}{c}\text { Мінфін (та } \\
\text { пов'язані } \\
\text { інституції) }\end{array}$ & $\begin{array}{c}\text { Загальні стратегї } \\
\text { розвитку } \\
\text { (пріоритети) } \\
\text { Моніторинг і } \\
\text { звіти про } \\
\text { макрофінансову } \\
\text { стабільність та її } \\
\text { складники } \\
\text { впродовж року } \\
\text { Поглиблений } \\
\text { аналіз } \\
\text { найбільших } \\
\text { дисбалансів } \\
\text { Прогнози щодо } \\
\text { макрофінансових } \\
\text { дисбалансів } \\
\text { Плани } \\
\text { коригуючих дій } \\
\text { Сповіщення про } \\
\text { санкції та їх } \\
\text { відміну } \\
\text { Формування } \\
\text { комунікації зі } \\
\text { «стейкхолдерами» } \\
\text { політики з } \\
\text { приводу } \\
\text { дисбалансів: } \\
\text { оприлюднення, } \\
\text { пояснення причин } \\
\text { тощо }\end{array}$ & $\begin{array}{c}\text { Конкретні } \\
\text { дати, за } \\
\text { об'єктивною } \\
\text { логікою } \\
\text { процедур та } \\
\text { згідно з } \\
\text { Податковим } \\
\text { та } \\
\text { Бюджетним } \\
\text { кодексами, } \\
\text { іншими } \\
\text { законами } \\
\text { України }\end{array}$ \\
\hline
\end{tabular}

Рис. 1. Основи українського інституційного дизайну макрофінансової безпеки

Джерело: створено авторами самостійно.

На рис. 1 презентовано такі ідеї щодо формування основ цілісного дизайну макрофінансової безпеки української економіки:

- ключовими складниками інституційного дизайну є три елементи: зміст діяльності (параметри економіки, відповідно, показники, через які виявляється макрофінансова стабільність і безпека), інститути (органи публічної влади, діяльність та взаємодія яких забезпечує макрофінансову стабільність), процедури (інструменти й терміни, 3 використанням яких інститути забезпечують макрофінансову стабільність); 
- основний зміст інституційного дизайну має формувати обмежене коло показників, яке, у нашому випадку, пропонується в складі 10-х позицій. Цей перелік охоплює більшість показників, якими користуються країни $\mathrm{CC}$, але містить й особливі показники, які віддзеркалюють особливості української економіки (9-та та 10-та позиції). Не виключено, що коло з 10-х показників може розширюватися за рахунок додаткових конкретизованих за сферами вимірників макрофінансової стабільності та безпеки;

- осердя дизайну макрофінансової безпеки формується навколо діяльності та взаємодії трьох інститутів публічної влади - НБУ, Мінфіну і Мінекономіки. Це випливає з природних функцій цих інститутів з огляду на сфери, щодо яких вони виступають національними регуляторами. За змістом діяльності трьох згаданих інститутів, віддзеркаленим у чинній нормативній базі та існуючій практиці, вони об’єктивно пов'язані $з$ конкретними показниками «українського табло». Відповідно, зміст діяльності з управління балансами (дисбалансами) мав би розподілятися у такий спосіб: НБУ - 1-й, 2-й, 3-й, 4-й, 5-й показники, Міністерство фінансів України - 5-й, 6-й, 7-й показники, Міністерство економіки України - 8-й - 9-й, 10-й показники. Ймовірною $є$ «перехресна» відповідальність, або співвідповідальність НБУ та Мінфіну щодо показника «Чиста міжнародна інвестиційна позиція (у \% до ВВП). Якщо таке припущення $є$ обгрунтованим, то це б передбачало формулювання додаткових вимог з розмежування відповідальності, відтак - $з$ узгодження процедур;

- в якості «пов'язаних» 3 основними інститутами, які в цьому інституційному дизайні $\epsilon,-$ НБУ, Міністерством фінансів України та Міністерством економіки України - можуть діяти державні агенції, комітети, спеціальні комісії (центри взаємодії) тощо. Ймовірно, що до «пов'язаних інституцій» можуть належати або нині діючі, або новостворені 3 новими повноваженнями, підпорядкуванням, компетенціями тощо;

- формування релевантного інституційного дизайну макрофінансової безпеки могло б охоплювати такі випробувані в практиці публічного управління інструменти: стратегії з відповідними пріоритетами розвитку всієї економіки та іï окремих сфер, звіти за показниками табло, поглиблений аналіз дисбалансів при найбільших відхиленнях від нормативних значень показників, короткострокові прогнози дисбалансів, плани коригуючих дій, сповіщення про санкції, налагодження комунікації зі стейкхолдерами та бенефіціарами (вигодоотримувачами) урядової монетарної фінансової, інноваційної, зайнятості тощо політик;

- терміни щодо застосування інструментів окремими інститутами потребують глибшого аналізу, з огляду на чинні нормативно-правові документи, для обгрунтування необхідних змін, а також для обгрунтування алгоритмів взаємодії цих інститутів; 
- суб'єктами, до яких мали б застосовуватися інструменти інституційного дизайну - звіти, аналіз діяльності, прогнози результатів, сповіщення про санкції тощо, - на наш погляд, мали би бути не лише безпосередні суб'єкти економічної (макрофінансової сфери), місцеві органи влади, а й власне інститути публічного управління в особі конкретних керівників, підрозділів пов'язаних владних інститутів тощо.

Як результати дослідження визначеної наукової проблеми згідно 3 окресленою метою, можуть бути подані такі висновки:

- найбільшою мірою завданню формування інституційного дизайну макрофінансової безпеки відповідає таке тлумачення змісту поняття «макрофінансова сфера»: «Це - сегмент національної економіки, в межах якого здійснюється взаємопов'язаність (узгодженість) руху фінансових та реальних активів»;

- макрофінансова стабільність (безпека) національної економіки може репрезентуватися фактичними значеннями доцільного (обгрунтованого) кола показників, використання яких сприяє виявленню диспропорцій у взаєминах фінансового та реального секторів, що можуть загрожувати цілісності національної економіки. Коло цих показників й алгоритми їх розрахунків можуть частково змінюватися у зв'язку 3 новими економічними обставинами та викликами, які постають перед суспільством та національними регуляторами;

- наразі, доцільним виглядає використання 10-х показників для оцінювання макрофінансової стабільності (безпеки) у складі: річного сальдо рахунку поточних операцій платіжного балансу, річної зміни реального обмінного курсу, річного темпу інфляції, показника достатності офіційних валютних резервів, частки державного боргу у ВВП, чистої міжнародної інвестиційної позиції, дефіциту державного бюджету, рівня безробіття, співвідношення між індексом продуктивності праці та індексом реальної заробітної плати;

- найбільш прийнятним для формування інституційного дизайну є таке тлумачення його змісту: «Це - система спроєктованих алгоритмів, правил, стимулів та обмежень, які забезпечують ціннісні орієнтири суспільства (громад) у певних сферах»;

- основними елементами інституційного дизайну макрофінансової безпеки можуть вважатися: 1) власне показники для оцінювання макрофінансової безпеки, 2) інститути публічної влади, 3) процедури інструменти та терміни, - 3 використанням яких забезпечується виявлення та коригування надмірних дисбалансів;

- об'єктивно причетними до регулювання макрофінансової сфери, з огляду на іiі зміст, є три основні національні регулятори НБУ, Мінфін та Мінекономрозвитку України, а також пов’язані з ними 
інституції публічної влади. Основними інструментами формування макрофінансової безпеки в межах створеного інституційного дизайну мають бути: стратегії розвитку, моніторинг та оцінювання, загальні й спеціальні звіти, прогнози дисбалансів, плани коригуючих дій, сповіщення про застосування та відміну санкцій, формування комунікацій між національними регуляторами і суспільством (громадами) 3 приводу надмірних дисбалансів;

- подальші дослідження в царині формування інституційного дизайну макрофінансової стабільності (безпеки) мали би здійснюватися за такими напрямками: вдосконалення способів (методик) оцінювання макрофінансових дисбалансів, контент-аналізу нормативно-правових документів на предмет урегульованості функцій, інструментів, термінів, розподілу повноважень та відповідальності між інститутами влади, якісного й кількісного аналізу ефективності існуючої системи публічного управління за результатами забезпечення макрофінансової стабільності, проєктування необхідних змін у всіх елементах інституційного дизайну.

\section{Jimepamypa:}

1. Comunale M. A panel VAR analysis of macro-financial imbalances in the EU: ECB Working Paper. 2017. №2026. URL : https://www.econstor.eu/ bitstream/10419/162689/1/88485681X.pdf.

2. Lanehttps $\mathrm{Ph}$. Macro-financial stability under EMU: Working Paper Series. February 2016. №1. URL : www.esrb.europa.eu/pub/pdf/wp/ esrbwp1.en.pdf.

3. Dewachter H., Iania L., Lemke W., Lyrio M. A macro-financial analysis of the corporate bond market. European Central Bank (ECB). Working Paper Series. 2018. №2214. URL : https://www.ssrn.com/abstract $=3299971$.

4. Benigno G., Chen H., Otrok Ch., Rebucci A., Young E. Optimal Policy for Macro-Financial Stability: Working Paper 2012-041. St. Louis Fed Publications. URL : https://doi.org/10.20955/wp.2012.041.

5. European Commission, Commission staff working paper scoreboard for the surveillance of macroeconomic imbalances: envisaged initial design. 2011. URL : http://www.europarl.europa.eu/sides/getDoc.do? pubRef=-//EP//TEXT+TA+P7-TA-2011-0583+0+DOC+XML+V0//EN.

6. European Commission, Technical note envisaged revision of selected auxiliary indicators of the MIP scoreboard. 2018. URL : https://ec.europa.eu/info/sites/info/files/economy-finance/technical_note_ proposal_mip_aux_indicators_revision_2018_final.pdf.

7. The Treaty of Maastricht or the European Union. 1992. URL : http://www.historiasiglo20.org/europe/maastricht.htm.

8. Про вплив політики державних запозичень та податкової політики на стан грошово-кредитної сфери України : Рішення Ради 
НБУ від 28.04.2020 №10-рд. URL : https://bank.gov.ua/ua/legislation/ Decision_28042020_10-rd.

9. Про діяльність Правління Національного банку України щодо виконання Основних засад грошово-кредитної політики в 2019 році : Рішення Ради НБУ від 25.02.2020 №4-рд. URL : https://bank.gov.ua/ua/ legislation/Decision_25022020_4-rd.

10. Про взаєморозуміння та співробітництво між Національним банком України, Національною комісією з цінних паперів та фондового ринку, Національною комісією, що здійснює державне регулювання у сфері ринків фінансових послуг, Фондом гарантування вкладів фізичних осіб та Міністерством фінансів України 3 питань підготовки та впровадження стратегії розвитку фінансового сектору України до 2025 р. : Меморандум від 28.05.2019 №101215. URL : https://zakon.rada.gov.ua/ laws/show/n0397500-19.

11. Про Рекомендації парламентських слухань на тему: «Актуальні питання зовнішньої політики України» : Постанова Верховної Ради України від 24.05.2017 №2069-VIII. URL : https://zakon.rada.gov.ua/laws /show/2069-19.

12. Про Звернення Верховної Ради України до інституцій Європейського Союзу щодо поглиблення співробітництва між Україною та Європейським Союзом : Постанова Верховної Ради України від 05.07.2018 №2490-VIII. URL : https://zakon.rada.gov.ua/laws /show/2490-19.

13. Стратегія макропруденційної політики НБУ (затверджена Правлінням НБУ в листопаді 2018 р.). URL : https://old.bank.gov.ua/ doccatalog/document?id=83019081.

14. Даниленко А. Що таке фінансова стабільність, та як центральні банки можуть іiі забезпечувати. URL : https://expla.bank.gov.ua/expla/ news_0026.html.

15. Методичні рекомендації щодо розрахунку рівня економічної безпеки України : Затверджено Наказом Міністерства економічного розвитку та торгівлі України 29.10.2013 №1277. URL : search.ligazakon. ua/1_doc2.nsf/link1/ME131588.html.

16. Методичні рекомендації щодо розрахунку рівня економічної безпеки України : Затверджено Наказом Міністерства економіки України 02.03.2007 №60. URL : http://consultant.parus.ua/?doc=03WN62 B99B.

17. Листи Міністерства розвитку економіки, торгівлі та сільського господарства України про надання інформації щодо інтегрального індексу економічної безпеки на запити про публічну інформацію від 24.04.2019 №3032-06/17571-09 та від 09.04.2020 №3032-06/23836-09.

18. Robert E. G. The Theory of Institutional Design, edited by Robert E. Goodin, Cambridge University Press. 1996.

19. Josep M. Colomer. Institutional Design. Prepared for: Handbook of Comparative Politics Todd Landmann and Neil Robinson eds. Sage, 2008. P. 246-262. 
20. David L. W. Institutional Design, edited by David L. Weimer, Kluwer Academic Publishers. 1995.

21. Пайманова В. А. Інституційний дизайн ринку капіталів як економічна категорія. Бізнесінформ. 2014. №7. С. 23-27.

22. Бунецький Л. Л. Інституційний дизайн сучасної української політики: криза ідентичності та конфлікт інтересів. Сучасна украӥнська політика. Політики і політологи про неї. К., 2010. Вип. 19. С. 120-136.

23. Про затвердження Технічного регламенту щодо встановлення системи для визначення вимог з екодизайну енергоспоживчих продуктів : Постанова Кабінету Міністрів України від 03.10.2018 №804. URL : https://zakon.rada.gov.ua/laws/show/804-2018-\%D0\%BF.

24. European Commission, «Communication from the Commission: Annual Sustainable Growth Strategy 2020». 2019. URL : https://eur-lex. europa.eu/legal-content/EN/TXT/?qid=1578392227719\&uri=CELEX\%3A5 2019DC0650.

25. European Commission, «Report from the Commission: Alert mechanism report 2020». 2019. URL : https://eur-lex.europa.eu/legal-content/ $\mathrm{EN} / \mathrm{TXT} /$ ?qid=1578392070452\&uri=CELEX\%3A52019DC0651.

26. Eurostat, Macroeconomic Imbalance Procedure Scoreboard. URL : https://ec.europa.eu/eurostat/documents/2995521/10266449/2-17122019BP-EN.PDF.

27. European Commission, «Communication from the Commission. 2020 European Semester: Assessment of progress on structural reforms, prevention and correction of macroeconomic imbalances, and results of indepth reviews under Regulation (EU) №1176(2011)». URL : https://eurlex.europa.eu/legal-content/EN/TXT/?qid=1584543632863\&uri=CELEX\% 3A52020DC0150.

28. European Commission, «Communication from the Commission on the 2020 Draft Budgetary Plans: Overall Assessment». 2019. URL : https://ec.europa.eu/info/sites/info/files/economy-finance/comm_chapeau_ 201119.pdf.

29. European Commission, «Recommendation for a Council recommendation on the National Reform Programme and delivering a Council opinion on the Stability Programme». 2019. URL : https://ec.europa.eu/info/ publications/2019-european-semester-country-specific-recommendationscommission-recommendations_en.

30. European Commission, «Proposal for a joint employment report from the commission and the council». 2020. URL : https://eur-lex.europa. eu/legal-content/EN/TXT/?qid=1578392632182\&uri=CELEX\%3A52019D C0653.

31. Official Journal of the European Union, «Regulation (EU) №1174/2011 on enforcement measures to correct excessive macroeconomic 
imbalances in the euro area». 2011. URL : https://eur-lex.europa.eu/legalcontent/EN/ALL/?uri=CELEX:32011R1174.

32. European Commission (2020), «National Reform Programme and Stability/Convergence Programme». 2020. URL : https://ec.europa.eu/ info/business-economy-euro/economic-and-fiscal-policy-coordination/eueconomic-governance-monitoring-prevention-correction/european-semester/ european-semester-timeline/national-reform-programmes-and-stabilityconvergence-programmes/2020-european-semester_en.

33. Проєкт Указу Президента України Про рішення Ради національної безпеки та оборони України «Про схвалення Положення про систему індикаторів (показників) стану національної безпеки України» від 2015 року та Проєкт Указу Президента України Про рішення Ради національної безпеки та оборони України «Про схвалення Положення про систему індикаторів (показників) стану національної безпеки України» від 2018 року. URL : https://www.rada.gov.ua.

34. Бюджетний кодекс України : Закон України від 08.07.2010 p. №2456-VI. Відомості Верховної Ради Украӥни (ВВР). 2010. №50-51. URL : http://zakon3.rada.gov.ua/laws/show/2456-17. 


\title{
ОСВІТА ТА ЕКОНОМІЧНА ВИЗНАЧЕНІСТЬ: ЗВ'ЯЗОК ЯВИЩ ТА ОСОБЛИВОСТІ РЕАЛІЗАЦІЇ ЩОДО РИНКУ НЕРУХОМОСТІ
}

\author{
Усик Віра Іванівна, \\ доктор економічних наук, професор кафедри, \\ ДВНЗ «Київський начіональний університет імені Вадима Гетьмана», \\ ORCID: https://orcid.org/0000-0002-0938-400X, \\ Дзюбко Віктор Васильович, \\ старший викладач кафедри теоретичної та прикладної економіки, \\ ВНЗ «Університет економіки та права «КРОК», \\ ORCID: https://orcid.org/0000-0003-0759-457X
}

Анотація. Розділ присвячено аналізу зв'язку між освітою та економічною визначеністю. Досліджено передавальні ланки в реалізації цього зв'язку. Окреслено вимоги до змісту і форм освіти з огляду на потреби сталого розвитку, нагромадження людського капіталу та реалізації результативної освітньої політики. Акцентовано увагу на підготовці фахівців для українського ринку нерухомості. Окреслено ті проблеми професіоналізації освіти для ринку нерухомості, вирішення яких сприятиме стабілізації ситуації власне на цьому ринку та в національній економіці загалом.

Ключові слова: освіта як фактор економічної визначеності, освітня політика, людський капітал, сталий розвиток, професіоналізація освіти, професіональна освіта для ринку нерухомості.

Актуальність дослідження впливу освіти на досягнення вищого рівня економічної визначеності пояснюється насамперед значним стабілізуючим потенціалом освіти. Факт існування такого потенціалу доведено багатьма економетричними дослідженнями та подіями історії багатьох країн. За обмежених можливостей і ресурсів розвитку економіки й суспільства освіта неодноразово ставала вирішальним чинником стабілізації. Важливо, що в якості чинника стабілізації освіта постає не автоматично. Діє певний передавальний механізм впливу освіти на економічну визначеність. На наш погляд, цей механізм має бути предметом спеціальних досліджень. Прикладне значення таких досліджень - це обгрунтування способів та форм модернізації освіти 3 урахуванням потреб вищого рівня економічної стабільності й визначеності.

В основу цього дослідження покладено гіпотезу про те, що зміст освіти, форми, в яких вона здійснюється, можуть створювати підгрунтя для вищого рівня економічної стабільності. 
Зв'язок між освітою та економічною визначеністю не $\epsilon$ безпосереднім. Він опосередкований певними ланками (елементами) особливого передавального механізму. Лише за певних умов ці ланки передаватимуть імпульси, отримані від освіти, у бік більшої економічної визначеності. За інших умов освіта може ставати чинником невизначеності. Ідею про передавальні елементи і логіку зв'язку між освітою та економічною визначеністю подано на рис. 1.

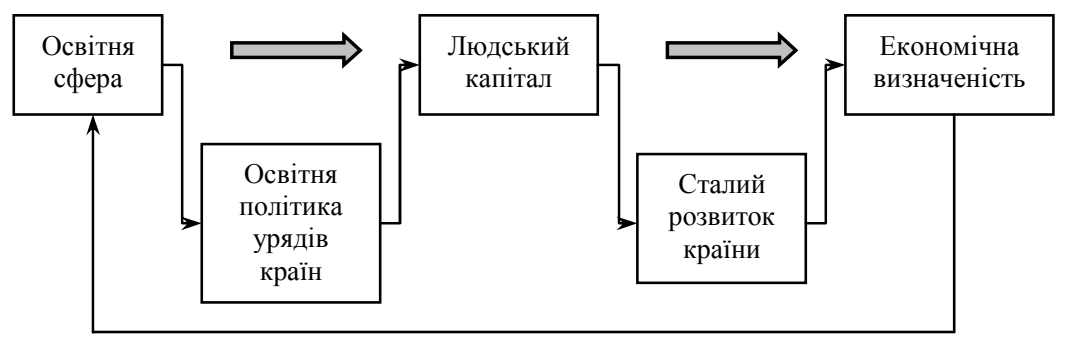

Рис. 1. Зв'язок освіти та економічної визначеності

Джерело: створено авторами самостійно.

3 використанням рис. 1 візуалізовано ідею про те, що освіта впливає на рівень економічної визначеності, передусім через людський капітал. Твердження про формування людського капіталу під впливом освіти $є$ традиційним, поширеним і незаперечним. Багато разів були перевірені й факти про вплив освіти через людський капітал на економічне зростання. Новизна ж запропонованого підходу, ілюстрованого на рис. 1, пов'язана 3 двома додатковими ідеями, а саме:

- про те, що зв'язок між освітою та формуванням i нагромадженням людського капіталу опосередковується політикою урядів, яку вони реалізують в освітній сфері (освітньою політикою);

- про те, що людський капітал забезпечує економічну визначеність тоді, коли використовується суспільством як ресурс сталого розвитку.

Для того щоб дійти висновку про освітню систему, здатну забезпечувати вищий рівень економічної визначеності, необхідно спиратися на уявлення про зміст економічної визначеності/невизначеності [1]. Для нашого дослідження важливими $є$ принаймні такі характеристики (ознаки) економічної визначеності:

- економічна визначеність пов'язана 3 волатильністю, тобто 3 відхиленнями економічних параметрів від певних рівноважних значень таких економічних змінних, як темпи економічного зростання, рівень зайнятості ресурсів, рівень цін тощо;

- економічна визначеність $є$ похідною від характеру очікувань економічних суб'єктів, відтак, вона суттєво залежить від інформованості 
й освіченості громадян, від довіри до публічної влади, до окремих спільнот тощо;

- економічна визначеність забезпечується інституиіоналізацією, тобто унормованістю економічних процесів, дотриманням цих норм, а також відповідністю створених норм об'єктивним потребам суспільства, яке розвивається.

Якщо вищий рівень економічної визначеності залежить від освіти, логічно обгрунтовувати пріоритети змін в освіті саме з потреб досягнення такої визначеності.

За логікою зв'язків, репрезентованих на рис. 1, економічна визначеність, сформована під впливом освіти, досягається тоді, коли розвиток країни набуває ознак сталого розвитку.

Як відомо, термін «сталий розвиток» $є$ офіційним українським відповідником англійського терміна «sustainable development». Останній, 3 огляду на контекст, може тлумачитися як «життєздатний розвиток», «внутрішньо підтримуваний розвиток», «збалансований розвиток» тощо.

За визначенням Комісії ООН зі сталого розвитку, мета останнього - це задоволення потреб сучасних поколінь без створення загроз для майбутніх поколінь задовольняти майбутні потреби. Теорія сталого розвитку є альтернативою до теорії економічного зростання на засадах екстенсивної моделі. Остання, зокрема, не акцентує увагу на екологічній небезпеці, вичерпності невідтворюваних природних ресурсів, які забезпечують економічне зростання. Поняття «сталий розвиток» та «стале зростання» використовуються як близькі за змістом.

Власне концепція сталого розвитку дозволила подивитися на економічне зростання, крім іншого, й під кутом зору економічної невизначеності. Зокрема, це відбулося й тому, що сталий розвиток пояснюється як той, що врівноважує економічні, соціальні та екологічні аспекти життя суспільства [2]. А в якості умов стійкого економічного зростання розглядаються гідні умови праці для всього населення працездатного віку, доступність фінансових активів, розвинена банківська та виробнича інфраструктура тощо [3].

Дотичними до проблем економіки невизначеності є актуальні ознаки економічного зростання, визначені у пріоритетах стратегії СС «Europe 2020». У документі йдеться про розумне зростання (за більш ефективних інвестицій в освіту, дослідження та інновації), про стале зростання (при низьковуглецевій економіці), про інклюзивне зростання (при створенні нових робочих місць та подоланні бідності) [4]. Ще більш важливі для нашого дослідження ідеї містить документ «Порядок денний сталого розвитку до 2030 року». У ньому сформульовано мету сталого розвитку, пов'язану з освітою, а саме: «...забезпечити всіх, хто навчається, знаннями та навичками, які необхідні для сприяння сталому розвитку...» [5]. 
Загалом, концепція сталого розвитку передбачає досягнення 17 цілей, кожна 3 яких у певний спосіб пов'язана з людським капіталом. Тому, за поширеним у науці уявленням, реалізація сталого розвитку забезпечується нагромадженням людського капіталу. Доведено, що ті країни, які інвестують у людський капітал, можуть суттєво підвищити свою конкурентоспроможність, особливо в умовах швидких змін. Тому адаптація економіки та суспільства до цих змін, отже, й вищий рівень визначеності, забезпечується нагромадженням людського капіталу.

Попри деякі відмінності у підходах до визначення поняття «людський капітал», у науці вже зафіксовано те, що є доведеним фактом:

- людський капітал створюється на основі «формального навчання, освіти та практичного досвіду» [6], він, як і будь-який інший капітал, передбачає інвестиції, передусім інвестиції в освіту;

- вищий рівень знань та навичок створює переваги i для окремих носіїв людського капіталу (кожний додатковий рік навчання помітно збільшує дохід людини [7; 8]), і для національної економіки загалом. Зокрема, перевищення певною країною на 1 в.п. середнього світового показника рівня людського капіталу корелює 32,5 в.п. відносного зростання продуктивності праці та 3 1,5 в.п. зростання валового національного доходу на одну особу.

- інвестиції в людський капітал - це фінансування в здоров'я, освіту та культуру, яке сприяє кращій адаптації до нових умов у швидко змінюваному світі [9], а відтак, ці інвестиції сприяють і більшій інклюзивності - включеності громадян у життя окремих спільнот та суспільства [10].

Зв'язок між власне освітою та людським капіталом, за нашою логікою, опосередковується освітньою політикою. Як і будь-яка інша, освітня політика охоплює цุiлi, що віддзеркалюють суспільні цінності та пріоритети. Освітня політика передбачає використання інструментів досягнення цілей і певні інститути, які забезпечують поєднання цілей та інструментів. Українські дослідники освітньої політики зазвичай акцентують увагу саме на цілях освітньої політики [11; 12]. Ймовірно, що таке акцентування пояснюється тим, що українська влада не демонструє глибокого розуміння правдивих актуальних цілей освітньої політики.

Для досягнення визначених цілей освітня політика має спиратися на певні правила - усвідомлені та інституційно забезпечені вимоги до діяльності. Правила стосуються як власне порядку надання освітніх послуг закладами освіти, так і державного фінансування освіти. Правила політики загалом та освітньої політики зокрема $\epsilon$, на наш погляд, необхідною умовою вищого рівня економічної визначеності. 
Оцінювання впливів політики, що здійснюється, на макроекономічну стабільність при порівнянні двох груп країн - 3 реалізованими та нереалізованими фінансовими правилами - дало важливі результати. Це висновок про те, що в країнах 3 традицією застосування правил зазвичай досягається вищий рівень економічної стабільності.

Освітня політика уряду, яка насамперед виявляється у рівні та способах фінансування освіти, стає предметом багатьох міжнародних досліджень. Зокрема, у звіті Свропейської асоціації університетів за 2020 р. виокремлено п'ять груп країн саме за критерієм зв'язку між фінансуванням освіти та економічним зростанням [13] (аналітична табл. 1).

Таблиця 1

Зв'язок показників фінансування освіти та темпів економічного зростання

\begin{tabular}{|l|l|l|}
\hline \multicolumn{1}{|c|}{ Показник } & \multicolumn{1}{|c|}{ Опис } & \multicolumn{1}{|c|}{ Країна } \\
\hline $\begin{array}{l}\text { Фінансування } \\
\text { освіти } \uparrow>\text { ВВП } \uparrow\end{array}$ & $\begin{array}{l}\text { Темпи фінансування освіти } \\
\text { вищі темпів економічного } \\
\text { зростання }\end{array}$ & $\begin{array}{l}\text { Австрія, Німеччина, Ісландія, } \\
\text { Люксембург, Хорватія, Данія, } \\
\text { Швеція, Швейцарія, Норвегія, } \\
\text { Португалія, Нідерланди, } \\
\text { Туреччина }\end{array}$ \\
\hline $\begin{array}{l}\text { Фінансування } \\
\text { освіти } \uparrow<\text { ВВП } \uparrow\end{array}$ & $\begin{array}{l}\text { Темпи фінансування освіти } \\
\text { нижчі темпів економічнго } \\
\text { зростання }\end{array}$ & $\begin{array}{l}\text { Франція, Польща, Угорщина, } \\
\text { Словенія, }\end{array}$ \\
\hline $\begin{array}{l}\text { Фінансування } \\
\text { освіти } \downarrow / \text { ВВП } \uparrow\end{array}$ & $\begin{array}{l}\text { Темпи фінансування освіти } \\
\text { знижуються, незважаючи } \\
\text { на економічне зростання }\end{array}$ & $\begin{array}{l}\text { Чсхія, Словаччия, Фінляндія, Естонандія, } \\
\text { Литва, Сербія, Румунія }\end{array}$ \\
\hline $\begin{array}{l}\text { Фінансування } \\
\text { освіти } \downarrow>\text { ВВП } \downarrow\end{array}$ & $\begin{array}{l}\text { Темпи фінансування освіти } \\
\text { знижуються швидше, ніж } \\
\text { відбувається економічний } \\
\text { спад }\end{array}$ & \\
\hline
\end{tabular}

Джерело: розроблено на основі [14].

Як свідчить інформація, подана в таблиці, три (перша, друга, четверта) групи країн демонстрували прямий зв'язок між витратами на вищу освіту та темпами економічного зростання. Тобто, у цих трьох групах країн зростання ВВП збільшувалося на тлі збільшення інвестицій в освіту і навпаки. Ці три групи охоплювали приблизно 65\% загальної кількості досліджуваних країн. Натомість, третя група демонструвала обернений зв'язок. Такі країни становлять приблизно 35\% кількості аналізованих країн.

Освітня політика урядів країн визначається не лише досягнутим економічним потенціалом, відповідно, можливостями державного фінансування освіти, а й демографічною ситуацією. До прикладу, в 
дослідженні Свропейської асоціації університетів репрезентовано різні моделі освіти, сформовані під впливом двох згаданих чинників фінансового та демографічного - у період 2008 - 2017 pp. (рис. 2).

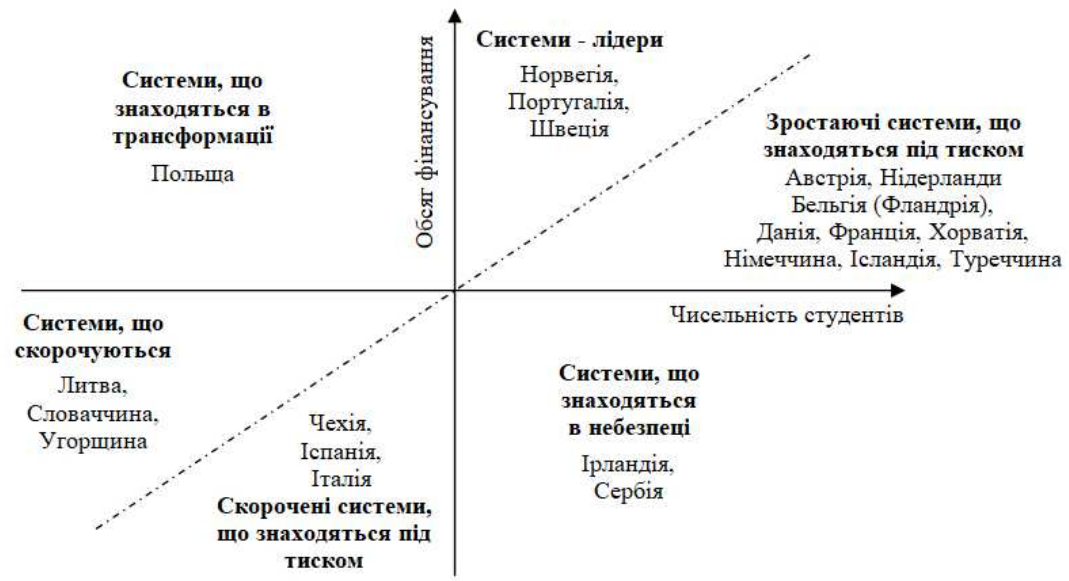

Рис. 2. Моделі освітньої політики країн СС, з огляду на фінансовий та демографічний чинники

Джерело: сформовано автором [15].

Оцінювання освітньої політики у двох координатах фінансування освіти державою та чисельності студентів - дає підстави для виокремлення групи країн-лідерів. Як ілюстровано на рис. 2, до групи лідерів належать Норвегія, Португалія, Швеція. Саме університети цих країн посідають високі місця в міжнародних рейтингах та мають стабільні й достатні, з огляду на зростання кількості студентів, обсяги фінансування. До «зростаючих систем», але таких, що «знаходяться під тиском», бо мають випереджаюче збільшення кількості студентів, належать Австрія, Нідерланди, Фландрія (регіон Бельгії), Данія, Франція, Хорватія, Німеччина, Ісландія, Туреччина. В особливих умовах функціонує освітня система Польщі. Вона ідентифікована як така, що «перебуває в трансформації» та діє при зростаючому державному інвестуванні в університети 3 метою призупинення відтоку молоді 3 навчальних закладів. Усі інші аналізовані країни мають загрожені освітні системи з тенденцією до скорочення.

Важливим складником освітньої політики є оцінювання витрат на освіту. За результатами дослідження під егідою Сврокомісії, з'ясовано важливу закономірність. Виявилося, що ефективність політики, яка оцінювалася за показниками кількості випускників та наукових публікацій, була вищою при більшій автономії університетів [16]. У 
фундаментальному дослідженні, присвяченому державним витратам на освіту в країнах $Є С$ [17], - «Роздуми економістів про інвестиції в людський капітал: наскільки ефективними є державні витрати на освіту в державах-членах СС?» - з'ясовано ще одну цікаву закономірність. Виявлено, що дуже обмежене коло країн ЄС забезпечує ефективність витрат на освіту одночасно за трьома вимірниками. Йшлося про оцінювання: за кількістю здобувачі вищої освіти (I), за якістю освіти за балами PISA (Programme for International Student Assessment) у галузі науки (II), за інклюзивністю, або інверсією молоді в навчальному процесі (III). Деякі країни мали високі результати лише за одними показниками і низькі - за іншими. Близько третини країн демонстрували низькі та спадаючі показники якості освіти, за критерієм PISA. Інформація про оцінювання країн за цим критерієм подана на рис. 3 .

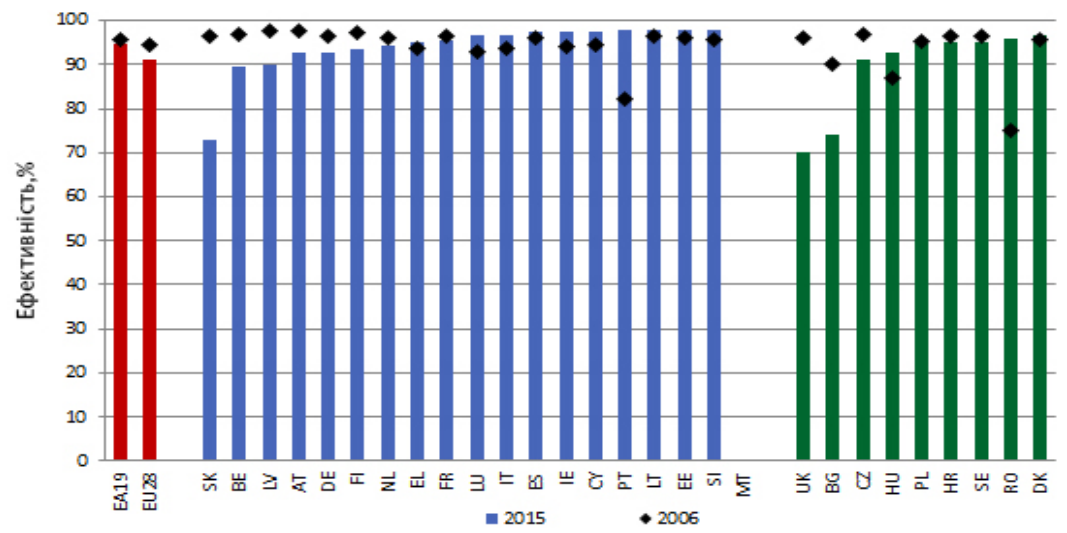

Рис. 3. Оцінка ефективності витрат на освіту, за критерієм PISA Джерело: [18].

Як свідчить ілюстрована на рис. 3 інформація, принаймні десять країн СС у аналізованому періоді демонстрували погіршення показників якості освіти. Показово, що це відбувається у спільноті країн 3 високими показниками добробуту, достатніми можливостями фінансування освіти та інвестиціями в людський капітал.

Для нашого дослідження впливу освіти на економічну невизначеність важливими $є$ такі узагальнення, зроблені при аналізі ефективності витрат на освіту в країнах $\mathrm{CC}$ :

- не існує ідеальної освітньої політики, зокрема через тяглість освітніх традицій і, відповідно, консервативність національних систем освіти; це заважає швидкому пристосуванню до змінюваного середовища;

- удосконалення людського капіталу в Європі відбувається не стільки через збільшення державних витрат на освіту, скільки через 
створення більш досконалих національних моделей використання фінансових ресурсів;

- особи 3 вищим рівнем освіти мають більшу здатність до реагування на загрози безробіття в період економічної невизначеності, натомість, безробіття серед осіб з низьким рівнем освіти в періоди невизначеності та криз суттєво зростає;

- достатнє фінансуванні освіти стає не лише фактором економічної стабільності, впливаючи на економічне зростання, вищу продуктивність та інноваційність, а й фактором соціальної стабільності, впливаючи на зменшення диференціації доходів та на подолання бідності.

Повертаючись до початкової ланки пропонованого нами логічного ланцюжка (рис. 1), через який ми намагалися пояснити вплив освіти на економічну невизначеність, можемо зробити такі узагальнення.

- Освіта, щоб стати інструментом гарантування стабільності, має сприяти найважливішим складникам стійкого розвитку - розумному зростанню (smart growth) та інклюзивному зростанню (inclusive growth). Розумне зростання передбачає, що система освіти забезпечує постійне навчання, оновлення навичок, здатність створювати нові продукти й послуги, використовувати нові джерела інформації та технології. Інклюзивне зростання спирається на те, що система освіти сприяє формуванню навичок спілкування $i$ взаємодї, створенню нових спільнот, участі в управлінні змінами тощо.

Про формування згаданих здатностей та навичок - постійного оновлення знань і взаємодії, участі тощо - йдеться, зокрема, в науковій доповіді про необхідні детермінанти сучасного зростання української економіки [19].

- Освіта покликана формувати иіннісні пріоритети суспільства, без яких жодні успіхи в економічній сфері не гарантуватимуть соціальної єдності та стабільності.

3 огляду на незаперечний факт вирішальної ролі освіти у формуванні цінностей суспільства, заслуговує на увагу ідея української дослідниці про, так званий «ланцюжок результативності освіти» у складі таких ланок: грамотність - освіченість - професійна компетентність - культура - менталітет [20].

- Обмеження економічної невизначеності досягається за рахунок вищого рівня професіоналізації освіти. Професіоналізація, як процес, передбачає здатність людини відповідати постійно змінюваним вимогам до професії. Тому професіоналізм грунтується принаймні на трьох засадах, а саме: 1) на опануванні фундаментальних знань та навичок професії, 2) на перманентному підвищенні кваліфікації, на самовдосконаленні в обраній сфері, 3) на реалізації загальнолюдських та національних цінностей при виконанні професійних функцій. 
Професіоналізація має більш широкий зміст, ніж той, що охоплюється поняттям «професійно-технічна освіта». Останнє в сучасних українських умовах корелює з поняттям так званої «фахової передвищої освіти» [21]. Увага до фахової передвищої освіти була породжена передусім браком на українському ринку праці кваліфікованих представників так званих «робітничих професій». Своєрідною реакцією на незадоволений попит у цьому сегменті ринку праці стала розробка Концепції реалізації державної політики у сфері професійної (професійнотехнічної) освіти «Сучасна професійна (професійно-технічна) освіта» на період до 2027 року [22]. Попри акцентовану увагу української влади до професійно-технічної освіти, проблема професіоналізації освіти, маючи ширший зміст, стала актуальною й для всіх інших сегментів ринку праці.

До ефективних заходів, що забезпечують загальну професіоналізацію освіти, належать такі:

- формування змісту освіти (освітніх програм) на компетентнісній основі - 3 урахуванням того, що повинен уміти, знати, передбачати професіонал, 3 огляду на змінювані обставини професії та потреби споживачів;

- залучення до освітнього процесу успішних професіоналів, професійних об'єднань та роботодавців;

- створення системи професійних кваліфікацій 3 чітким окресленням кола компетентностей фахівців певної професії;

- поєднання різних і найбільш прийнятних для отримувача освіти форм професійної освіти та форм перекваліфікацій.

Перспективними заходами 3 професіоналізації освіти, що носять ознаки інноваційності та апробовані в освітніх системах різних країнах, $€$ такі:

- організація освітнього процесу у формі освітніх кластерів, які поєднують навчальні, наукові заклади та підприємства й організації;

- створення служб супроводу процесу безперервної професійної освіти таких, як, наприклад, адаптаційні, діагностичні, дидактичні, психологічні центри тощо;

- узгодження міжнародних (до прикладу, європейської) рамок кваліфікації з відповідними національними рамками кваліфікації;

- поєднання в освітніх програмах вищих навчальних закладів «навчальних одиниць»- ECTS (European Credit Transfer and accumulation System) 3 «професійними одиницями» - ECVET (European Credit System for Vocational Education and Training);

- створення нових освітніх інституцій - національних центрів, орієнтованих на забезпечення вищого рівня професіоналізму та зайнятості молоді. Наприклад, таких, як італійський центр «Відкриті двері в 
майбутнє» - Porto Futuro, французький центр - Citedes Metries, іспанський центр - Porta 22;

- створення організаційних структур від середньої до вищої, які об'єднують освітні рівні з виробництвом та спрямовують навчання у русло здобуття конкретних кваліфікацій та професій. Наприклад, таких організаційних структур, як кампуси професій і кваліфікацій (Campus des métiers et des qualifications) у Франції, професійні центри компетентності в Латвії.

Зроблені нами узагальнення щодо зв'язку освіти та економічної визначеності $€$ важливими, з огляду на можливість їх застосування в українській економіці. Помічено, що різні складники української економіки демонструють різні рівні економічної визначеності та стабільності. До прикладу, ринок нерухомого майна впродовж усіх років новітньої української економічної історії, починаючи з 1990-х рр., виконував роль своєрідного «амортизатора економіки». Йдеться про нерухоме майно - квартири, споруди, офісні приміщення тощо, - яке завжди було найбільш привабливим активом та об'єктом інвестування для українців. Такі переваги нерухомого майна як активу пояснюються постійним браком альтернативних форм фінансових активів 3 подібним рівнем дохідності, корисності та ризиковості (надійності) вкладень.

Про відносно вищу, ніж у інших сегментах української економіки, стабільність ринку нерухомості свідчить, зокрема, стабільна частка ВВП. На «операції з нерухомим майном» припадає 8-10\% ВВП [23]. На цьому ринку знаходять місця для працевлаштування приблизно 200 тис. українців.

Попри відносно високий «потенціал економічної визначеності», властивий ринку нерухомого майна, він характеризується значною волатильністю. Адже зазвичай він одним з перших реагує на зміни економічної кон'юнктури. Зокрема, так сталося у 2020 р. під час пандемії Covid-19. Ринок нерухомості та ринок туристичних послуг першими відреагували скороченнями продажів на негативні зовнішні впливи та негативні очікування громадян.

Дослідження ринку нерухомого майна на предмет реакції фактичних та потенційних споживачів його послуг засвідчили достатньо високий рівень недовіри. 3'ясовано, що недовіра формується, крім іншого, й через масову відсутність розуміння того, чим займаються та що повинні вміти фахівці цього ринку.

Відсутність більш-менш чітких уявлень про фах, професійні функції операторів на ринку нерухомості властива не лише споживачам послуг. Подібне нерозуміння часто демонструють і національні регулятори цього ринку. Адже в Україні десятиліттями точиться дискусія з приводу того, хто й як має навчати фахівців ринку нерухомості, як має засвідчуватися їх кваліфікація, здійснюватися сертифікація. 
Тобто, освіта фахівців ринку нерухомості є тією «сферою невизначеності», яка перманентно породжує невизначеність на самому ринку. Саме тому актуальним $\epsilon$ вивчення досвіду організації освіти фахівців ринку нерухомості в інших країнах. Не менш важливим $є$ й усвідомлення можливостей застосування такого досвіду для організації подвійної освіти в Україні.

Визначальним орієнтиром для організації освіти фахівців ринку нерухомості може слугувати стандарт «Послуги агентів 3 нерухомості Вимоги до надання послуг агентів 3 нерухомості», затверджений Європейським комітетом з стандартизації, кваліфікації та компетенцій агентів з нерухомості [24].

Перелік професійних компетенцій агентів 3 нерухомості $\epsilon$ принципово важливим для усвідомлення того, якою має бути освіта фахівців цього ринку. Власне перелік охоплює 12 позицій, а саме:

1) розуміння найважливіших фінансових, економічних термінів, пов'язаних з операціями з нерухомістю;

2) обізнаність щодо грошових, кредитних та банківських систем, пов'язаних з сектором нерухомості;

3) інформованість про економічну та політичну ситуації, пов'язані 3 сектором нерухомості;

4) усвідомлення чинників попиту та пропозиції в секторі нерухомості;

5) супровід здійснення інвестицій у нерухомість;

6) маркетинг нерухомості, володіння маркетинговими методами у їх застосуванні для різних видів нерухомості;

7) оцінювання витрат, пов'язаних з використанням нерухомого майна, наприклад, експлуатаційних, спричинених необхідністю страхування тощо;

8) знання принципів та процесів гарантування операцій 3 нерухомістю, а саме: законодавства і практики застосування іпотеки, банківських позик та інших фінансових інструментів;

9) володіння інструментарієм оцінки ринкової вартості нерухомості;

10) здатність здійснити перевірку та вимірювання площ різних типів нерухомості з урахуванням мети вимірювання,

11) обізнаність у царині основ національного та європейського законодавства, нормативів і стандартів, що стосуються підприємництва у сфері нерухомості, оподаткування, охорони праці, екології тощо;

12) здатність складати договори, пов'язані з нерухомістю, або сприяти їх складанню, експертиза існуючих договорів за наслідками певних змін для сторін договору.

Аналіз наведеного переліку компетенцій фахівців ринку нерухомості, за їх змістовим наповненням, дає підстави для виокремлення принаймні чотирьох необхідних складників освіти таких фахівців: 
- економічний компонент (економічна термінологія щодо ринку нерухомості, вплив макроекономічного середовища на ринок, фактори попиту та пропозиції на ринку, інвестування в нерухоме майно, оцінка ринкової вартості нерухомого майна);

- правовий компонент (правові основи гарантування операцій $з$ нерухомістю, застосування норм права у підприємницькій діяльності на ринку нерухомості, укладання та експертиза договорів щодо нерухомого майна);

- фінансовий компонент (володіння фінансовою термінологією щодо ринку нерухомості, обізнаність у царині банківської (кредитної) системи для ринку нерухомості);

- маркетинговий компонент (маркетинговий інструментарій дослідження на ринку нерухомості).

3 огляду на значний обсяг економічних знань, необхідних фахівцеві ринку нерухомості, ми схильні до висновку про доцільність підготовки таких фахівців на основі базової економічної освіти. Зрозуміло, що економічні знання мають органічно поєднуватися з трьома іншими елементами освітнього процесу. Йдеться про правовий, фінансовий та маркетинговий компоненти у застосуванні саме до ринку нерухомості.

Далі подано десять прикладів 3 досвіду реалізації освітніх програм, пов'язаних з підготовкою фахівців для ринку нерухомості, в розвинених країнах зі сформованим та інституціоналізованим ринком (аналітична табл. 2).

Таблиия 2

Освітні заклади та програми підготовки фахівців для ринку нерухомості

\begin{tabular}{|l|l|l|}
\hline \multicolumn{1}{|c|}{ Освітні заклади } & $\begin{array}{l}\text { Партнери, долучені до } \\
\text { освіти фахівців, та/або } \\
\text { професійні спільноти, } \\
\text { що здійснюють освітню } \\
\text { діяльність }\end{array}$ & \multicolumn{1}{|c|}{ Зміст освітньої програми } \\
\hline $\begin{array}{l}\text { Флоридський } \\
\text { міжнародний університет } \\
\text { (Маямі, США) }\end{array}$ & $\begin{array}{l}\text { Школа нерухомості Hollo } \\
\text { та Вища школа бізнесу } \\
\text { Алва Х. Чепмена }\end{array}$ & $\begin{array}{l}\text { Програма навчання 3 } \\
\text { міжнародного управління } \\
\text { нерухомістю }\end{array}$ \\
\hline $\begin{array}{l}\text { Баухауз-Університет } \\
\text { Веймару (Веймар, } \\
\text { Німеччина) }\end{array}$ & $\begin{array}{l}\text { Бакалаврські та магістерські } \\
\text { програми з менеджменту зі } \\
\text { спеціалізацією у сфері } \\
\text { нерухомості й майстер-класами } \\
\text { практикуючих фахівців ринку }\end{array}$ \\
\hline $\begin{array}{l}\text { Антверпенська школа } \\
\text { менеджменту } \\
\text { (Антверпен, Бельгія) }\end{array}$ & $\begin{array}{l}\text { Сдина в країні магістерська } \\
\text { програма з нерухомості, яка дає } \\
\text { можливість отримати диплом } \\
\text { магістра з нерухомості (МRЕ) з } \\
\text { відповідними тренінгами }\end{array}$ \\
\hline
\end{tabular}


Продовження табл. 2

\begin{tabular}{|c|c|c|}
\hline $\begin{array}{l}\text { Kogod School of Business } \\
\text { (Вашингтон, США) }\end{array}$ & $\begin{array}{l}\text { Професійні асоціації } \\
\text { нерухомості США }\end{array}$ & $\begin{array}{l}\text { Магістерська програма } 3 \\
\text { нерухомості зі спеціалізацією: } \\
\text { комерційний розвиток та } \\
\text { інвестиційний банкінг, іпотечне } \\
\text { фінансування }\end{array}$ \\
\hline $\begin{array}{l}\text { Массачусетський } \\
\text { технологічний інститут } \\
\text { (США) }\end{array}$ & $\begin{array}{l}\text { Центр нерухомості (1983 } \\
\text { р. заснування), створений } \\
\text { відомим американським } \\
\text { девелопером, } \\
\text { випускником } \\
\text { Массачусетського } \\
\text { технологічного інституту } \\
\text { Ч. Сполдингом }\end{array}$ & $\begin{array}{l}\text { Магістерська програма з розвитку } \\
\text { нерухомості, що охоплює курси } \\
\text { «Фінанси та розвиток } \\
\text { нерухомості», «Економіка } \\
\text { нерухомості», «Стратегічний } \\
\text { розвиток нерухомості», «Складні } \\
\text { міські проєкти», «Ризики } \\
\text { нерухомості», «Лідерство у } \\
\text { сфері нерухомості» тощо }\end{array}$ \\
\hline $\begin{array}{l}\text { Неаполіський університет } \\
\text { у Пафосі (Кіпр) }\end{array}$ & $\begin{array}{l}\text { Королівський інститут } \\
\text { дипломованих геодезистів } \\
\text { у регіоні Східного } \\
\text { Середземномор'я } \\
\end{array}$ & $\begin{array}{l}\text { Перша спеціальна програма } 3 \\
\text { нерухомості для Кіпру та Греції }\end{array}$ \\
\hline $\begin{array}{l}\text { Гронінгенський } \\
\text { університет (Гронінген, } \\
\text { Нідерланди) }\end{array}$ & $\begin{array}{l}\begin{array}{l}\text { Королівський інститут } \\
\text { дипломованих геодезистів }\end{array} \\
\end{array}$ & $\begin{array}{l}\text { Міждисциплінарна магістерська } \\
\text { програма в галузі нерухомості, } \\
\text { побудована у співпраці } \\
\text { факультетів просторових наук, } \\
\text { економіки та права } \\
\end{array}$ \\
\hline $\begin{array}{l}\text { Люцернський університет } \\
\text { прикладних наук і } \\
\text { мистецтв (Люцерн, } \\
\text { Швейцарія) }\end{array}$ & & $\begin{array}{l}\text { Навчальна програма зі } \\
\text { спеціалізацією: ринки } \\
\text { нерухомості та інвестиції в } \\
\text { нерухомість з тренінгами від } \\
\text { фахівців ринку } \\
\end{array}$ \\
\hline $\begin{array}{l}\text { Кембридж (Велика } \\
\text { Британія) }\end{array}$ & & $\begin{array}{l}\text { Програма «Оцінка ринків } \\
\text { нерухомості» як самостійна та як } \\
\text { навчальний курс } 3 \text { такою ж } \\
\text { назвою в інших програмах } 3 \\
\text { тренінгами від фахівців } \\
\end{array}$ \\
\hline $\begin{array}{l}\text { Школа архітектури та } \\
\text { дизайну в складі IE } \\
\text { University (Іспанія) }\end{array}$ & & $\begin{array}{l}\text { Магістерська програма з } \\
\text { підготовки фахівців з розвитку } \\
\text { нерухомості зі спеціалізацією у } \\
\text { сфері інвестицій у міську } \\
\text { інфраструктуру з відповідними } \\
\text { тренінгами }\end{array}$ \\
\hline
\end{tabular}

Джерело: створено авторами самостійно на основі інформації, поданої на сайтах відповідних освітніх закладів.

Узагальнюючи досвід освіти фахівців ринку нерухомості, спираючись на наведені приклади, можна фіксувати таке:

1. Існують різні моделі освіти фахівців ринку нерухомості, а саме:

a) на магістерському (переважаюча модель) та на бакалаврському рівнях;

б) у межах інших, більш широких напрямків підготовки (менеджерського, економічної аналітики, фінансового тощо рівнів) та 
власне в межах спеціального напрямку - фахівців ринку нерухомості 3 отриманням диплому магістра нерухомості.

2. Заклади вищої освіти можуть забезпечувати професійну підготовку, в різний спосіб будуючи свої взаємини з практиками ринку нерухомості: а) координуючи свою діяльність 3 професійними громадськими об'єднаннями, б) залучаючи окремих успішних фахівців та аналітиків ринку до освітнього процесу.

3. Попри відмінності у моделях та способах підготовки фахівців для ринку нерухомості, вона здійснюється у вищих навчальних закладах (університетах) різних країн. Отже, передбачається, що цей фах спирається на широкі (універсальні) знання і певний світогляд, а не лише на вузькі функції та просте механічне відтворення певних дій.

4. Освіта фахівців ринку нерухомості має багато спеціалізацій, включно з тими, які пов'язані з новими процесами у містобудуванні, у вирішенні екологічних проблем тощо. Тому освітніми програмами передбачено різні - змінювані під актуальні потреби суспільства акценти у підготовці фахівців ринку нерухомості.

Український ринок нерухомості не можна вважати ні розвиненим, ні остаточно сформованим через неврегульованість процедур та процесів. Ідеться передусім про процеси надання професійної освіти, здійснення сертифікації фахівців тощо.

Попри остаточну несформованість ринку нерухомості, на ньому вже виокремилися принаймні чотири професії, що дістали визнання в українському суспільстві: оцінювачі майна, агенти з нерухомого майна (рієлтори), управляючі нерухомістю (включно 3 управляючими багатоквартирними будинками), дівелопери.

Для згаданих професій сформувалася певна система підготовки фахівців. Аналіз цих систем дає можливість окреслити основні проблеми освіти фахівців українського ринку нерухомості. Інформацію про фактичний стан освіти фахівців ринку нерухомості подано в аналітичних табл. 3-6.

За інформацією, поданою в аналітичній табл. 3, підготовка фахівців ринку нерухомості у сегменті оцінювачів майна здійснюється органом державної влади - Фондом державного майна - та згідно 3 чинним Законом України. Це надає такій підготовці достатньо високого рівня легітимності. Зміст програм, на які ми посилаємося, на наш погляд, звужує роль оцінювачів майна. Адже в програмах найбільше акцентується увага на «оцінці для цілей оподаткування». Натомість, оцінка майна має значно ширше коло економічних, фінансових, соціальних наслідків, ніж просто сприяння збільшенню податкових надходжень до бюджету. 
Таблиия 3

Українська професійна освіта в оціночній діяльності

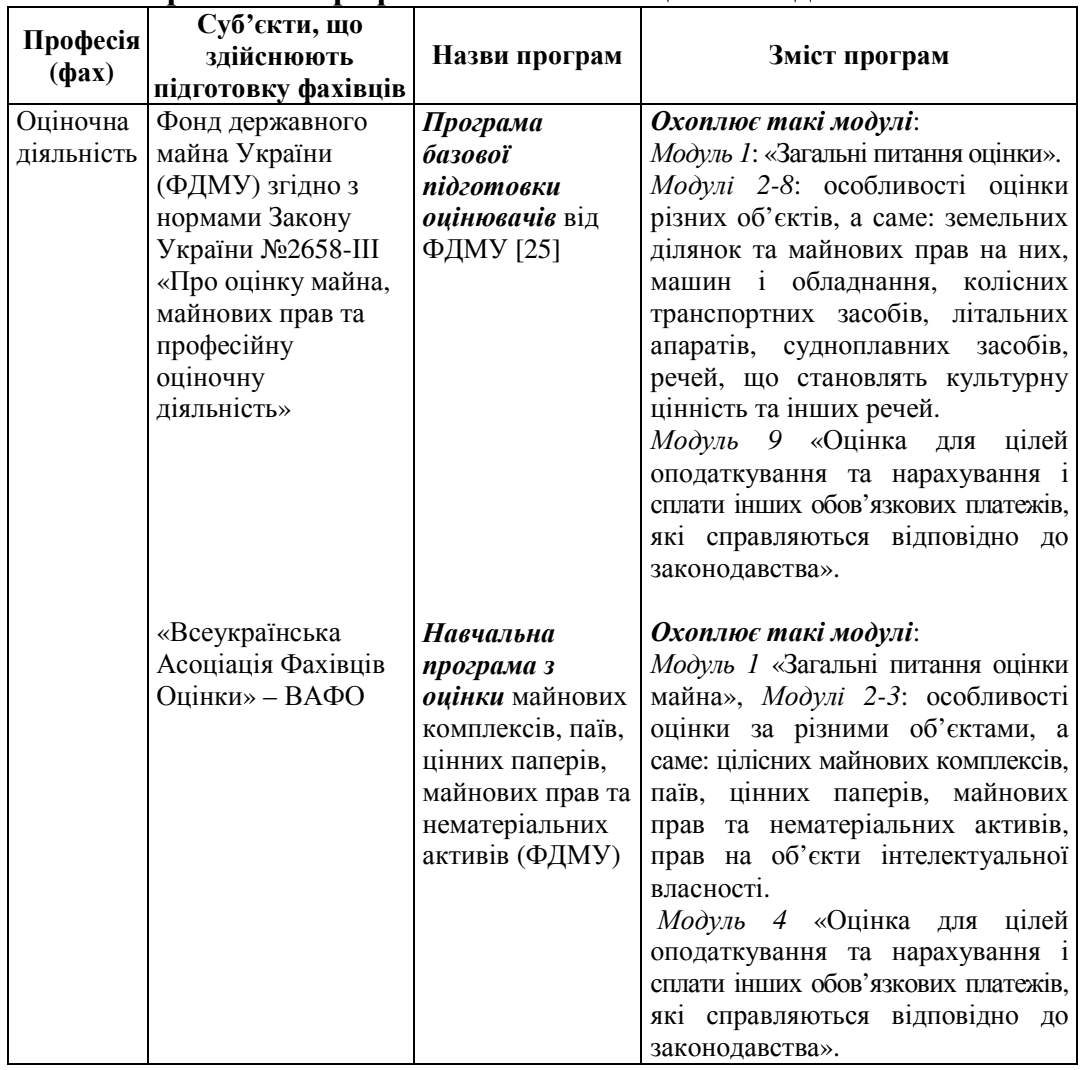

Джерело: створено авторами самостійно.

Таблиия 4

Українська професійна освіта в діяльності агентів нерухомості (ріслторів)

\begin{tabular}{|c|c|c|c|}
\hline $\begin{array}{l}\text { Професія } \\
\text { (фах) }\end{array}$ & $\begin{array}{c}\text { Суб'скти, що } \\
\text { здійснюють } \\
\text { підготовку } \\
\text { фахівців }\end{array}$ & $\begin{array}{c}\text { Назви } \\
\text { програм }\end{array}$ & Зміст програм \\
\hline $\begin{array}{l}\text { Агент } 3 \\
\text { нерухомого } \\
\text { майна } \\
\text { (рієлтор) } 3 \\
\text { елементами } \\
\text { підготовки } \\
\text { керуючого } \\
\text { нерухомістю }\end{array}$ & $\begin{array}{l}\text { Громадська } \\
\text { організація } \\
\text { «Асоціація } \\
\text { фахівців } \\
\text { нерухомості } \\
\text { (рієлторів) } \\
\text { України»- } \\
\text { АФНРУ в } \\
\end{array}$ & \begin{tabular}{|l|} 
Цикл \\
навчальних \\
курсів СРМ \\
(Ступінь \\
Certified \\
Property \\
Manager - \\
Сертифікований \\
\end{tabular} & $\begin{array}{l}\text { Охоплюс такі теми: } \\
\text { «Обслуговування власності та } \\
\text { управління ризиками», «Основи } \\
\text { управління людськими ресурсами для } \\
\text { керуючих нерухомістю», «Маркетинг і } \\
\text { оренда: нерухомість для роздрібної } \\
\text { торгівлі», «Маркетинг і оренда: } \\
\text { багатоквартирна нерухомість», }\end{array}$ \\
\hline
\end{tabular}


Продовження табл. 4

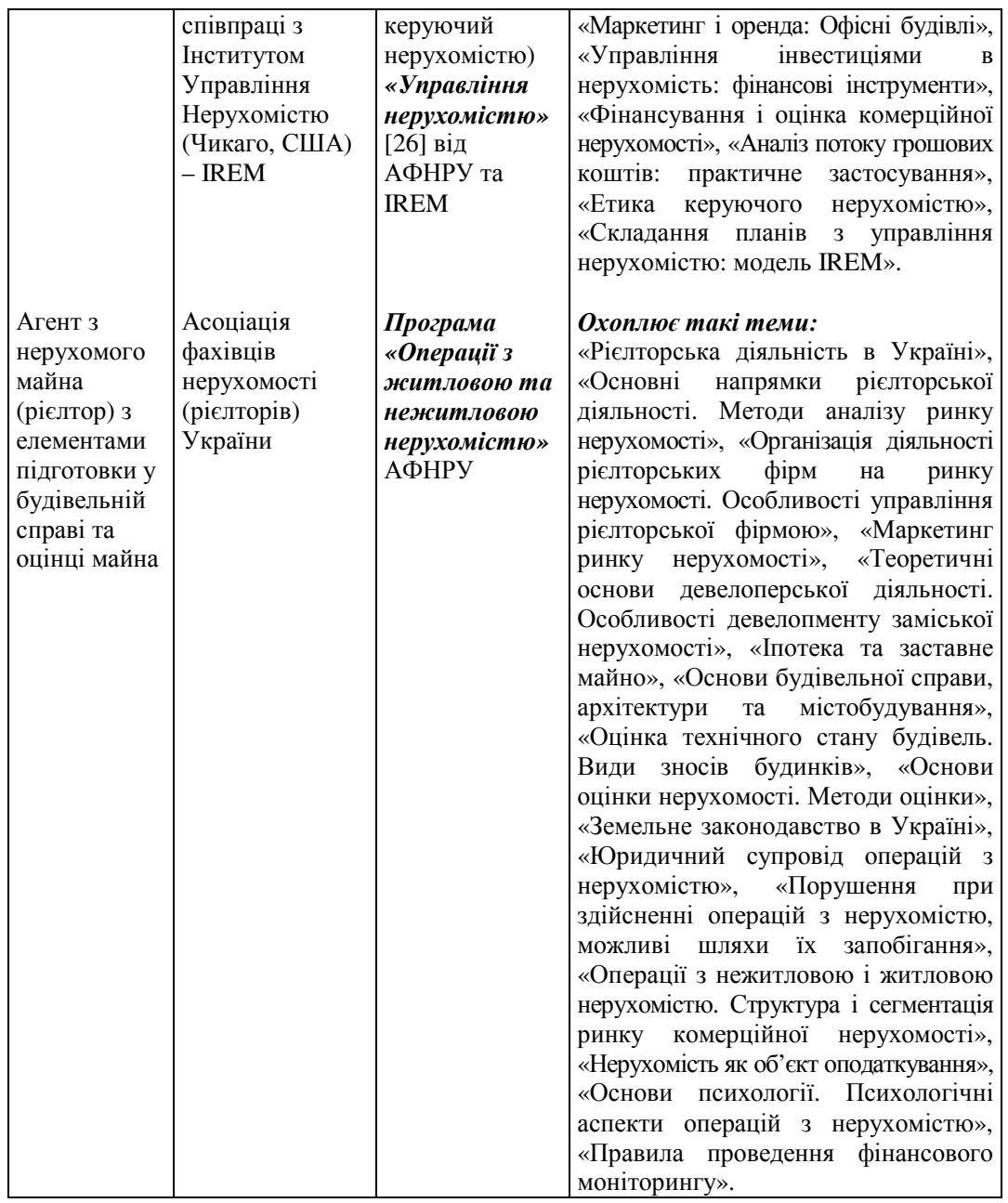

Джерело: створено авторами самостійно.

Аналіз інформації, поданої в аналітичній табл. 4, дає підстави для таких узагальнень щодо чинної системи професійної підготовки агентів нерухомості (рієлторів):

- дві чинні пропоновані програми, передбачаючи широке коло компетенцій, є подібними до програм університетів інших країн. Це надає їм незаперечні переваги. Але ці програми передбачають нетривалу в часі підготовку фахівців. Тому, ймовірно, в повному обсязі вони 
можуть бути засвоєні лише особами, які вже мають економічні, маркетингові, фінансові, правові, психологічні тощо знання та практичні навички. Саме такі знання й навички передбачено університетською освітою;

- зміст аналізованих програм не свідчить про чіткі уявлення щодо кваліфікації (так званої «кваліфікаційної рамки») агента 3 нерухомості (рієлтора). Такий висновок випливає, на наш погляд, принаймні з того, що програма «заводить» цей фах у сферу будівельної справи.

Таблиия 5

Українська професійна освіта в управлінні нерухомістю

\begin{tabular}{|c|c|c|c|}
\hline $\begin{array}{c}\text { Професія } \\
\text { (фах) }\end{array}$ & $\begin{array}{c}\text { Суб'скти, що } \\
\text { здійснюють } \\
\text { підготовку } \\
\text { фахівців } \\
\end{array}$ & $\begin{array}{c}\text { Назви } \\
\text { програм }\end{array}$ & Зміст програм \\
\hline $\begin{array}{l}\text { Управляючий } \\
\text { на ринку } \\
\text { нерухомості }\end{array}$ & \begin{tabular}{|l} 
Київський \\
національний \\
торговельно- \\
економічний \\
університет - \\
КНТЕУ
\end{tabular} & $\begin{array}{l}\text { Професійна } \\
\text { програма } \\
\text { підвицення } \\
\text { кваліфікації } \\
\text { менеджерів } \\
\text { ринку } \\
\text { нерухомості } \\
\text { КНТЕУ }\end{array}$ & $\begin{array}{l}\text { Охоплює такі теми: } \\
\text { «Аналіз структури ринку нерухомості», } \\
\text { «Введення в девелопмент, в архітектуру } \\
\text { та містобудування», «Правові аспекти } \\
\text { діяльності на ринку нерухомості, види } \\
\text { договорів», «Основи фінансового та } \\
\text { інвестиційного менеджменту на ринку } \\
\text { нерухомості», «Основи оціночної } \\
\text { діяльності та управління дохідною } \\
\text { нерухомістю», «Практика роботи на } \\
\text { ринку послуг з нерухомості та кодекс } \\
\text { етики фахівців з нерухомого майна», } \\
\text { «Просування послуг на ринку } \\
\text { нерухомості, основи побудови баз } \\
\text { даних та інформаційне забезпечення } \\
\text { діяльності фірм з нерухомості», } \\
\text { «Формування психологічної готовності } \\
\text { рієлтора до успішної професійної } \\
\text { діяльності та психологія конфліків». }\end{array}$ \\
\hline
\end{tabular}

Джерело: створено авторами самостійно.

Подана в табл. 5 інформація свідчить про те, що український вищий навчальний заклад КНТЕУ пропонує не систему освіти фахівців ринку нерухомості, а систему їх перепідготовки. Відтак, передбачається, що відповідна освіта та практичний досвід уже попередньо отримані. Тому існування такої програми не вирішує питання про власне систему освіти «управляючих на ринку нерухомості».

Власне факт існування навчальної програми, презентованої у табл. 6, та факт сертифікації менеджерів (управителів) багатоквартирними будинками $\epsilon$ адекватною реакцією професійної спільноти в особі ЕМАУ. Це відповідь на формування нового сегменту ринку нерухомості й нових, раніше не задоволених потреб споживачів. У зв'язку 3 
аналізованою програмою, як і в зв'язку з іншими програмами, виникає обгрунтований сумнів. Він стосується того, чи може бути повноцінною підготовка у стислі терміни, якщо учасники програми не мають необхідних знань у царині права, економіки, управління тощо.

Таблиця 6

Українська професійна освіта в управлінні нерухомістю в частині багатоквартирних будинків

\begin{tabular}{|c|c|c|c|}
\hline $\begin{array}{c}\text { Професія } \\
\text { (фах) }\end{array}$ & $\begin{array}{c}\text { Суб'скти, що } \\
\text { здійснюють } \\
\text { підготовку } \\
\text { фахівців }\end{array}$ & Назви програм & Зміст програм \\
\hline $\begin{array}{l}\text { Менеджери } \\
\text { (управителі) } \\
\text { багатоквар- } \\
\text { тирними } \\
\text { будинками }\end{array}$ & $\begin{array}{l}\text { Громадська } \\
\text { спілка } \\
\text { «Експертна } \\
\text { Міжгалузева } \\
\text { Асоціація } \\
\text { України»- } \\
\text { ЕМАУ }\end{array}$ & $\begin{array}{l}\text { Програма підготовки } \\
\text { менеджерів } \\
\text { (управителів) } \\
\text { багатоквартирного } \\
\text { будинку (групи } \\
\text { будинків) та/або } \\
\text { керівного складу } \\
\text { підприємства } \\
\text { житлово-комунального } \\
\text { господарства (ЖКГ) } \\
\text { від ЕМАУ }\end{array}$ & $\begin{array}{l}\text { Oxоплюс такі модулі: } \\
\text { «Організаційно-правові та економічні } \\
\text { аспекти діяльності з управління та } \\
\text { утримання житлового комплексу», } \\
\text { «Техніко-технологічні аспекти } \\
\text { безпечної експлуатації та утримання } \\
\text { житлового комплексу», «Сучасні } \\
\text { стандарти менеджменту та програмні } \\
\text { засоби з управління та утримання } \\
\text { житлового комплексу». }\end{array}$ \\
\hline
\end{tabular}

Джерело: створено авторами самостійно.

Загальні висновки з аналізу української освіти фахівців ринку нерухомості, на наш погляд, можуть бути такими:

- чинна фрагментарна освіта фахівців не $\epsilon$ системою, легітимізованою на основі релевантного законодавства та узгодження з професійними спільнотами вимог до кваліфікації;

- лакуни існуючої системи освіти фахівців ринку активно компенсуються діяльністю громадських організацій - ВАФО, АФНРУ, ЕМАУ, - які зацікавлені в професіоналізмі всіх операторів ринку та членів згаданих асоціацій;

- освіта, пропонована за ініціативою професійних асоціацій, має низку обмежень, пов'язаних з термінами, викладацькими кадрами, джерелами додаткових витрат тощо, тому не може бути цілком покладена на ці асоціації;

- освіту фахівців ринку доцільно здійснювати в поєднанні зусиль університетів, що надаватимуть базову освіту, та професійних асоціацій, які, співпрацюючи 3 університетами в наданні базової освіти, організовуватимуть професійну сертифікацію, визнання кваліфікації та перекваліфікацію;

- органи державної влади (комісії, комітети, фонди тощо) можуть бути учасниками системи освіти фахівців ринку в ролі так званих «третіх осіб», не претендуючи на роль «перших осіб» в освітньому процесі. 
Одна 3 можливих моделей освіти потенційних фахівців ринку нерухомості реалізується в Університеті «КРОК» на кафедрі теоретичної та прикладної економіки (КТПЕ). Ця модель грунтується на таких засадах:

- імплементації в освітні програми бакалаврського рівня двох спеціальностей - 051 «Економіка» та 076 «Підприємництво, торгівля та біржова діяльність» - дисциплін за вибором студентів, що стосуються економіки нерухомості, оцінки нерухомості та підприємництва на ринку нерухомості;

- узгодження переліку та змісту пропонованих кафедрою дисциплін за вибором студентів 3 професійними асоціаціями фахівців ринку нерухомості, а саме: з АФРНУ та ЕМАУ;

- залучення до освітнього процесу викладачів, які мають досвід роботи в якості професійних оцінювачів, рієлторів, управляючих нерухомістю, власників рієлторських, оціночних тощо агенцій;

- створення при кафедрі ТПЕ Лабораторії управління капіталом та майном, до функцій якої належить організація мінітренінгів та семінарів від провідних фахівців ринку нерухомості.

\section{Висновки:}

Дослідження зв'язку між освітою та економічною визначеністю дає підстави для таких узагальнень:

- освіта сприяє досягненню вищого рівня економічної визначеності тоді, коли іiі заміст та форми забезпечують нагромадження людського капіталу за вимогами сталого розвитку. Останній передбачає реагування на технічні інновації та адаптивність і залученість (інклюзію) громадян до життя суспільства;

- вплив освіти на формування людського капіталу, зазвичай, опосередкований освітньою політикою. В іiі межах обираються інструменти й правила, включно з тими, що стосуються державного фінансування освіти. Критеріями успішності освітньої політики та ефективності витрат держави на освіту має бути не лише зростання кількості осіб, охоплених освітою, а й досягнення показників якості освіти за визнаними суспільством стандартами;

- вищий рівень економічної визначеності пов'язаний 3 професіоналізацією освіти - процесом, який означає формування здатності відповідати змінюваним вимогам до професії. Така відповідність досягається при поєднанні неперервної освіти та професійної діяльності з участю у професійних спільнотах тощо;

- одним із сегментів української економіки, досягнення стабільності в якому суттєво залежить від формування системи освіти та сертифікації спеціалістів, є ринок нерухомості. Професіоналізація освіти фахівців цього ринку передбачає упорядкування національної кваліфікаційної 
рамки, обрання релевантної моделі освіти й моделі визнання кваліфікації та іiі офіційне визнання. Перспективною моделлю професіоналізації освіти для ринку нерухомості $є$ поєднання університетської економічної освіти 3 іншими елементами. Йдеться про поєднання 3 орієнтованою на потреби ринку нерухомості фінансовою, правовою, маркетинговою освітою. Ще більш впливовими учасниками, замовниками змісту освіти та оцінювачами ії якості мають ставати громадські професійні асоціації фахівців ринку нерухомості.

\section{Лimepamypa:}

1. Sustainable Development. OECD. 2011. URL : https://www.oecd.org/ greengrowth/47445613.pdf.

2. Promote inclusive and sustainable economic growth, employment and decent work for all. URL : https://www.un.org/sustainabledevelopment/ economicgrowth.

3. Бобух I. М., Щегель С. М. Стратегічні орієнтири економічного зростання України: інклюзивність як ключовий пріоритет. Вісник Національної академії наук Украӥни. 2018. №7. С. 55-70.

4. Перетворення нашого світу: Порядок денний у сфері сталого розвитку до 2030 року. ПРООН в Україні. URL : http://www.ua.undp.org/ content/ukraine/uk/home/library/sustai/nable/developmentreport/the2030ag endaforsustainabledevelopment.html.

5. Долан Э. Дж., Линдсей Д. Е. Рынок: микроэкономическая модель. СПб., 1992.

6. Center for Global Development. «Education and The Developing World». 2014. URL : https://www.cgdev.org/ publication/educationanddeve lopingworld.

7. Smith J. P., Welch, F. R. Closing the gap: Forty years of economic progress for Blacks. (R3330DOL). Santa Monica: The Rand Corporation. 1986.

8. Шульга Н. Д. Основні напрями вдосконалення державної освітньої політики як інструмента соціально-економічного розвитку країни. Вісник післядипломної освіти. Серія : Управління та адміністрування. 2017. Вип. 3. С. 138-150. URL: http://nbuv.gov.ua/ UJRN/vpoupra_2017_3_13.

9. The role of education in the sustainable development agenda. Empowering a learning society for sustainability through quality education. URL : https://www.google.com/url? sa=t\&rct=j\&q=\&esrc/=s\&source=web $\& c d=4 \& v e d=0$ ahUKEwiGmurYkMbaAhWQbFAKHacQDlkQFghIMAM \& url=https3A2F2Fpub.iges.or.jp2Fpub_file2F05ch5achievingthesdgspdf2Fdo wnload\&usg=AOvVaw1CYZk9Uqf0oQ8NScDavd2C.

10. The Human Capital Project. 2018. URL : https://openknowledge. worldbank.org/handle/10986/30498. 
11. Корсак К. В. Освіта, суспільство, людина в XXI столітті: інтегрально-філософський аналіз. Київ-Ніжин, 2004. 210 с.

12. Шульга Н. Д. Державна освітня політика як інструмент соціально-економічного розвитку України: теоретико-методологічний аналіз : монографія. Київ : НТУ, 2016. 355 с.

13. Economic Governance - Guidelines for Effective Financial Management (Paperback). United Nations. New York, 2000. URL : https://publicadministration.un.org/publications/content/PDFs/ELibrary20 Archives/200020Economic20Governance_Guidelines/20for20Effective20 Financial20Management.pdf.

14. Pruvot Enora Bennetot, Estermann Thomas, Lisi Valentina. Public Funding Observatory Report. 2018. URL : https://eua.eu/downloads/ publications/eua20pfo20201820report_1420march202019_final.pdf.

15. Enora Bennetot Pruvot, Thomas Estermann, Veronika Kupriyanova. Public Funding Observatory. Report 2019/2020. URL : https://www.eua.eu/ resources/publications/913:eua-public-funding-observatory-report-2019-20.html.

16. Pruvot Enora Bennetot, Estermann Thomas, Lisi Valentina. Public Funding Observatory Report. 2018. URL : https://eua.eu/downloads/ publications/eua20pfo20201820report_1420march202019_final.pdf.

17. St. Aubyn, M., Garcia, F., \& Pais, J. Study on the efficiency and effectiveness of public spending on tertiary education. Directorate General Economic and Financial Affairs (DG ECFIN), European Commission. 2009. №390.

18. Economists' Musings on Human Capital Investment: How Efficient is Public Spending on Education in EU Member States? European Commission. URL : https://ec.europa.eu/info/publications/economy-finance/ economists-musings-human-capital-investment-how-efficient-publicspending-education-eu-member-states_en.

19. Національні та глобальні детермінанти економічного зростання України: наукова доповідь / за ред. I. М. Бобух. Київ, 2018. 390 с. URL : http://ief.org.ua/docs/sr/299.pdf.

20. Новосад О. В. Освіта як вища цінність людини і суспільства. Управління в освіті. V Міжнародної науково-практичної конференції, 14-16 квітня 2011 року : збірник матеріалів. Львів : Видавництво Львівської політехніки, 2011. С. 225-227.

21. Про фахову передвищу освіту : Закон України від 06.06.2019 №2745-VIII. URL : https://zakon.rada.gov.ua/laws/show/2745-19.

22. Про схвалення Концепції реалізації державної політики у сфері професійної (професійно-технічної) освіти «Сучасна професійна (професійно-технічна) освіта» на період до 2027 року : Розпорядження КМУ від 12 червня 2019 р. №419-p. URL: https://www.kmu.gov.ua/npas/ pro-shvalennya-koncepciyi-realizaciyi-derzhavnoyi-politiki-u-sferiprofesijnoyi-profesijno-tehnichnoyi-osviti-suchasna-profesijna-profesijnotehnichna-osvita-na-period-do-2027-roku-i120619. 
23. Dunia Pepe, Piera Casentini Innovation in VET: Italy. CEDEFOP. ReferNet. URL : https://cumulus.cedefop.europa.eu/files/vetelib/2014/2014 _Innovation_in_VET_IT.pdf.

24. Services of real estate agents - Requirements for the provision of services of real estate agents. URL : https://www.en-standard.eu/csn-en15733-services-of-real-estate-agents-requirements-for-the-provision-ofservices-of-real-estate-agents/.

25. Офіційний сайт Фонду Державного майна України. URL : http://www.spfu.gov.ua/ua/content/spf-estimate-trainings-basic.html.

26. Офіційний сайт Асоціації спеціалістів 3 нерухомості (рієлторів) України. URL : http://www.asnu.net/. 


\title{
АНАЛІЗ НА ОСНОВІ БАЗ ДАНИХ (DATА SCIENCE) ДЛЯ УПРАВЛІНСЬКИХ РІШЕНЬ \\ З УРАХУВАННЯМ НЕВИЗНАЧЕНОСТІ МАКРО- TА МІКРОЕКОНОМІЧНОГО РІВНІВ
}

\author{
Радіонова Ірина Федорівна, \\ доктор економічних наук, професор, \\ ДВНЗ Київський національний університет імені Вадима Гетьмана, \\ ВНЗ «Університет економіки та права «КРОК», \\ ORCID: https://orcid.org/0000-0002-0941-2867, \\ Фаренюк Яна Валеріївна, \\ аспірантка, \\ Київський національний університет імені Тараса Шевченка, \\ ORCID: https://orcid.org/0000-0001-6837-5042
}

Анотація. Цей підрозділ монографії присвячено важливій науковій та прикладній проблемі пояснення та оцінювання економічної невизначеності для прийняття управлінських рішень. Сформульовано й перевірено припущення про іманентність для вирішення цієї проблеми інструментарію Data Science. Висновки щодо придатності такого інструментарію верифіковано із застосуванням модельних конструкцій макроекономічного та мікроекономічного рівнів.

Ключові слова: інструментарій Data Science, Data Mining, моделі нейронних мереж, регресійні моделі, моделі тактичного планування діяльності.

Актуальність досліджуваної проблеми пояснюється тим, що явище невизначеності національної економіки передбачає використання особливого інструментарію аналізу. Цей інструментарій має бути складнішим та витонченішим, ніж той, що придатний до застосування у рівноважних економіках зі стійким економічним зростанням. Українська економіка, за характером змін та за діючими механізмами відтворення, $\epsilon$ економікою невизначеності. Тому управлінські рішення на загальнонаціональному рівні та на рівні окремих економічних суб'єктів передбачають адекватне реагування на фактори невизначеності, ідентифіковані з використанням особливого інструментарію.

Одним із головних припущень дослідження $є$ ідея про те, що порівняно більш відповідним (релевантним) для аналізу економіки невизначеності $€$ інструментарій Data Science. Саме це припущення верифікується у цьому дослідженні та на підставі верифікації зроблено певні управлінські узагальнення та висновки.

Метою дослідження $є$ виявлення на конкретних прикладах аналізу та уточнення можливостей Data Science в оцінюванні економічної 
невизначеності. Йдеться про невизначеність на мікроекономічному та макроекономічному рівнях. Ця мета досягається у процесі застосування інструментарію Data Science під час аналізу значних масивів економічної інформації з використанням доступного програмного забезпечення.

Достатньо поширеним та таким, що не викликає заперечень, $\epsilon$ визначення Data Science як науки про роботу зі значними масивами (базами) даних 3 метою виокремлення неочевидної (прихованої за великою кількістю подій) інформації про існуючі зв'язки та залежності. Зрозуміло, що віднайдена неочевидна інформація має стати підгрунтям для прийняття більш обгрунтованих, i тому результативніших, управлінських рішень.

Для усвідомлення можливостей Data Science в аналізі невизначеності доцільно деталізувати зміст цієї науки з виокремленням iï структурних елементів (складників) (рис. 1).

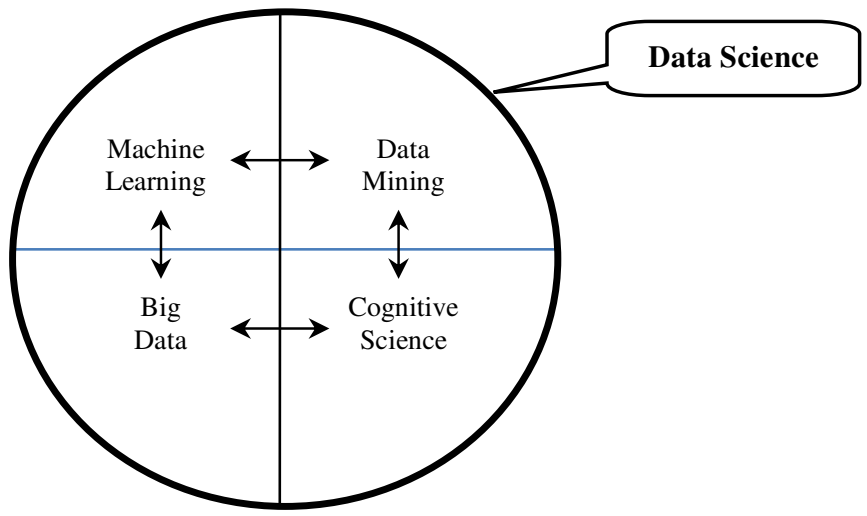

Рис. 1. Зміст Data Science за структурними елементами Джерело: створено авторами самостійно на основі [1-5].

За рис. 1, Data Science є інтегральною аналітичною наукою. Вона формується при безпосередньому використанні здобутків принаймні чотирьох напрямків наукових досліджень, що грунтуються на певних ідеях та інструментарії, а саме:

- Cognitive Science - наука про загальні закономірності мислення та алгоритми пізнання світу, які реалізуються в різних галузях знань, до прикладу, в праві, фінансах, медицині, мистецтві, економіці тощо;

- Machine Learning - наука про ефективні способи навчання та самонавчання систем з використанням створених комп'ютерних програм, які застосовують алгоритми пізнання світу, включно 3 побудовою штучних нейронних мереж (Artificial Neural Network) [6];

- Big Data - наука про технології генерування та правила організації великих баз даних, їх візуалізацію та репрезентацію; 
- Data Mining - наука про виокремлення з великих баз даних, за правилами програмового (машинного) навчання, неочевидних, але об'єктивно існуючих, отже, корисних для усвідомленого прийняття рішень, зв'язків (залежностей) та закономірностей.

Здатність Data Science забезпечувати відповідний (релевантний) аналіз економіки у стані невизначеності передусім пов'язана з виявленням неочевидних зв'язків (залежностей).

На наш погляд, неочевидні зв'язки (залежності) мають такі типові критеріальні ознаки:

- не перебувають «на поверхні» явищ, тому не виявляються емпіричним шляхом або «на практиці», як, наприклад, ідентифікується достатньо очевидний зв'язок між попитом та цінами конкретного ринку, між витратами виробництва та випуском тощо;

- не випливають 3 масово усвідомлених теоретичних конструкцій, які зазвичай грунтуються на логічному (дедуктивному) виведенні одного явища з іншого, як, наприклад, виведення інфляції з необгрунтованого (несподіваного) зростання окремих елементів сукупного попиту або вплив девальвації національної валюти на діяльність експортерів;

- спричиняються дискретно випадковими факторами («чорними лебедями»), які через обмеженість інтелектуальних можливостей спільнот і пересічних економічних суб'єктів, а також через обмеженість технічних можливостей аналізу не можуть бути передбачені з необхідною точністю;

- не є очікуваними, тобто такими, до яких економічні суб'єкти можуть пристосуватися адаптивним, раціональним, псевдораціональним або іншим шляхом;

- не можуть бути виявлені традиційними методами обробки інформації й потребують досконалішого інструментарію, який або ще не створено, або створено, але не використовується через неусвідомлення його переваг та можливостей.

Є підстави припускати, що вказані ознаки неочевидності зв'язків (залежностей) процесів та явищ формують осердя економіки невизначеності. В українській економіці до зафіксованих нами критеріальних ознак неочевидності додається й невизначеність зв'язків, породжена незавершеністю об'єктивно необхідних перетворень (реформ), хаотичністю в діях владних інститутів, відсутністю спадковості, отже, перервністю (дискретністю) позитивних традицій публічного управління економікою тощо.

Data Science-аналіз спирається на науковий фундамент різних шкіл та напрямків економіко-математичних досліджень, у межах яких вирішується завдання виявлення й оцінювання невизначеності.

Ретроспективний аналіз дає підстави для виокремлення певних етапів еволюції досліджень явища невизначеності:

- теорія ігор, ідеї якої сформульовано у 1940-х рр. Дж. фон Нейманом і О. Моргенштерном, а завданням визнано аналіз економічної 
поведінки та прийняття рішень в умовах невизначеності та конфліктних ситуацій;

- економіко-математичне моделювання 1950-х - 1980 рр. 3 його новим для того періоду інструментарієм, який охоплює принаймні шість напрямків:

1) динамічні та стохастичні моделі, що враховують фактор випадковості та невизначеності (Р. Фріш, Я. Тінберген, С. Кузнець, К. Ерроу, Л. Клейн та ін.);

2) ітеративні методи для розв'язання задач великої розмірності (Н. Н. Боголюбов, Н. М. Крилов, М. Ф. Кравчук, А. Ю. Лучка);

3) методи сіткового планування (критичного шляху СРМ, оцінки та аналізу програм PERT), що дозволяють мінімізувати тривалість проєктів із урахуванням різноманітних чинників впливу;

4) моделі одночасних рівнянь, що передбачають охоплення системою окремих рівнянь $з$ різним рівнем ідентифікації та різними залежними змінними, що пов'язані між собою (Т. Купманс, Т. Хаавельмо, Г. Гейл та ін.);

5) удосконалені моделі економічного розподілу та оцінки ресурсів, зокрема оцінки капіталовкладень з позицій теорії двоїстості (Г. Лемке, А. У. Таккер та ін.);

6) оптимізаційні моделі перспективного планування, які використовуються при розробці більш обгрунтованих перспективних планів господарського розвитку на основі пізнання найважливіших економічних пропорцій і співвідношень, темпів зростання виробництва й рівнів споживання, раціональної галузевої структури (Л. В. Канторович, В. С. Немчинов, В. Л. Макаров, А. Б. Горстко);

- моделі поведінки соціально-економічних систем та оцінювання ïх керованості, що активно розробляються з кінця ХХ ст. і передбачають використання математичного інструментарію принаймні у таких двох особливих формах:

1) лінійних та нелінійних диференціальних рівнянь для ідентифікації ефектів запізнення в реакції систем на впливи (В. Вольтерра, А. Д. Мишкіс, Н. Н. Боголюбов, Д. Я. Хусаїнов, В. І. Фодчук);

2) нечіткої логіки з формалізацією у вигляді нечітких множин на основі експертного оцінювання (Л. Заде).

Показовим $\epsilon$ те, що певний потенціал для оцінювання невизначеності формують і достатньо прості інструменти економетричного аналізу. Це, зокрема, стосується множинної регресії - методу багатовимірного аналізу, за допомогою якого залежна змінна пов' язується 3 сукупністю незалежних змінних (регресорів). Дослідження інструментарію дає підстави стверджувати, що власне еволюція регресійного аналізу відбувалася в бік віднайдення способів оцінювання невизначеності. Йдеться про перехід від простої лінійної регресії до 
нелінійної, а також до авторегресії з лаговими значеннями змінних для оцінювання тривалості імпульсних «відгуків» та до використання в регресійних рівняннях, так званих «фіктивних змінних».

Кожен згаданий інструмент економетричного аналізу, забезпечуючи певні переваги, має й обмеження. Таким типовим обмеженням $є$ те, що за надмірно великих обсягів інформації виникає потреба в їі обмеженні та спрощенні. Це спричиняє деформоване модельне відображення дійсності й, відповідно, недосконалість рішень, які спираються на модельні конструкції. Саме це обмеження частково долається, наприклад, 3 використанням штучних нейронних мереж (Neural Networks). Економетричні моделі та штучні нейронні мережі $\epsilon$ інструментами Machine Learning, а, отже, складником Data Science (рис. 1).

За логікою моделей штучних нейронних мереж, вхідні сигнали складаються та, проходячи через передавальну (трансмісійну) функцію, генерують вихідний результат. Вхідні сигнали формують певні прошарки (шари, або «вузли») взаємодії, тому система цієї взаємодії є багаторівневою.

Штучні нейронні мережі вирішують багато завдань, мають більші, ніж інші інструменти, аналітичні можливості. Найважливішою, 3 огляду на мету нашого дослідження, $є$ можливість їх використання для аналізу з неповною інформацією при присвоєнні кожній операції певного рівня ризику [7]. Саме у такий спосіб формуються додаткові можливість аналізу невизначеності.

Застосування інструментарію Data Science в економічних дослідженнях загалом та дослідженнях на макроекономічному рівні зокрема вже має власну історію і традицію. Найчастіше фокусом дослідження 3 використанням інструментарію Data Science ставали такі об'єкти:

- волатильність курсів валют у двосторонніх відносинах між країнами [8];

- прибутковість фінансового ринку, динаміка фондових індексів [9];

- динаміка ВВП, економічні шоки та «поворотні» точки у процесі економічних коливань [10;11];

- фактори цінових коливань та динаміка інфляції [12; 13];

- ефективність окремих видів економічної політики, зокрема 3 використанням конструкцій, орієнтованих на агентів і творців політики (agent-based modelling in economics and policy-making) [14; 15].

Застосування Data Science на макроекономічному рівні ілюструватимемо на прикладі побудови нейронних мереж у дослідженні двох макроекономічних явищ - економічного зростання та диференціації доходів. Як і всі інші процеси та явища української економіки, обрані нами для дослідження змінні мають високий рівень невизначеності. Зокрема, тренд на економічне зростання у 2016 - 2018 pp. несподівано переривається гальмуванням у 2019 р. та значним спадом 2020 р. 
Останній не пояснюється виключно факторами Covid-19 та світовою кризою, а має в українській економіці та суспільстві й інші особливі суттєві внутрішні причини.

У дослідженні феноменів економічного зростання та рівня диференціації доходів використовувалися дані за 31-им показником української економіки за період $1992-2018$ рр. Для забезпечення однорідності статистичної інформації було максимально використано наявні в базах МВФ [16] дані по Україні. 3 метою продовження рядів даних за 1990-і рр., які не містилися в інформації МВФ, використані два інші джерела за шість років [17; 18].

Усі наявні показники розподілено на ендогенні, тобто ті, що пояснюються в моделях, та п’ять груп показників екзогенних, тобто тих, з використанням яких відбувається пояснення. Такими ендогенними показниками визначено два, а саме: темп економічного зростання та коєфіцієнт Джинні. Відбір цих показників узгоджується 3 нашою метою пояснити економічне зростання та диференціацію доходів в українській економіці з використанням інструментарію Data Science. Ендогенні змінні розподілено на п'ять груп:

1) досягнутого рівня розвитку національної економіки;

2) соціальні;

3) фінансові;

4) монетарні;

5) ресурсного потенціалу економіки.

Розподіл екзогенних змінних моделі на п'ять груп $є$ достатньо умовним і таким, що не має суттєвого технічного навантаження при побудові моделей та поясненні результатів.

Умовність поділу показників 3 бази досліджуваних даних виявляється, зокрема, у тому, що частина з них може бути віднесена як до однієї, так і до іншої групи. До прикладу, ми виходимо з того, що два показники фінансування освіти $-\mathrm{G}_{\text {educ }} / \mathrm{G}$ та $\operatorname{Exp}_{\mathrm{G} / \mathrm{st}} / \mathrm{Y}_{\mathrm{N}}-$ належать до показників досягнутого рівня розвитку. Підставою для цього $€$ уявлення, що саме рівень і якість фінансування освіти, зокрема освіти вищої (університетської), найбільше віддзеркалює рівень розвитку і економіки, і суспільства. Натомість, можливий інший підхід, за яким показники фінансування освіти подаватимуться як такі, що належать виключно до групи фінансових. Підставою для такої їх приналежності $\epsilon$ відображення через них пропорції розподілу державного бюджету. Отже, в основу поділу показників на групи можуть покладатися різні теоретичні припущення, тому будь-який існуючий поділ $є$ «умовно правильним».

Однак, поділ екзогенних показників на певні групи, попри його умовність, є необхідним для так званого передмодельного аналізу. В його межах на рівні загальновідомих та усвідомлених теоретичних 
конструкцій вирішується питання про те, від чого «в принципі» може залежати досліджувана змінна. Зокрема, за новою класичною теорією, економічне зростання передусім залежить від ресурсного потенціалу економіки, від досягнутого рівня продуктивності, від заощадження та інвестування у технічний прогрес тощо. Відтак, ідеться про показники, охоплені, за нашою класифікацією, групами 1 i 5 . Натомість, у кейнсіанській теорії економічне зростання пояснюється у зв’язку 3 фінансовими, кредитними показниками та показниками доходів, через які відбувається вплив на сукупні витрати. Отже, йдеться про показники виокремлених нами 2-ої, 3-ої, 4-ої груп.

Перелік показників, на основі яких будувалися дві нейронні мережі, подано у табл. 1.

Таблиця 1

Повний перелік показників, що використовувалися для побудови двох штучних нейронних мереж

\begin{tabular}{|c|c|c|}
\hline $\begin{array}{c}\text { Позначення } \\
\text { показника } \\
\text { латинськими } \\
\text { літерами }\end{array}$ & Зміст показника & $\begin{array}{c}\text { Порядковий } \\
\text { номер } \\
\text { показника в } \\
\text { моделі }\end{array}$ \\
\hline \multicolumn{3}{|c|}{ Ендогенні (пояснювані) змінні моделі } \\
\hline $\mathrm{g}_{\mathrm{Y}}$ & Темп економічного зростання (\%) & 6 \\
\hline $\mathrm{k}_{\mathrm{Gin}}$ & Коєфіцієнт диференціації доходів Джинні & 2 \\
\hline \multicolumn{3}{|c|}{ Показники досягнутого рівня розвитку економіки } \\
\hline $\mathrm{Y} / \mathrm{N}$ & ВВП на одного громадянина (дол. США) & 1 \\
\hline $\mathrm{Im} / \mathrm{Y}$ & Частка імпорту у ВВП (\%) & 16 \\
\hline $\mathrm{Ex} / \mathrm{Y}$ & Частка експорту у ВВП (\%) & 17 \\
\hline $\mathrm{S}_{\mathrm{N} / \mathrm{Y}}$ & Частка національних заощаджень у ВВП (\%) & 15 \\
\hline $\mathrm{G}_{\text {educ }} / \mathrm{G}$ & Витрати на освіту в державних витратах (\%) & 26 \\
\hline $\operatorname{Exp}_{\mathrm{G} / \mathrm{st}} / \mathrm{Y}_{\mathrm{N}}$ & $\begin{array}{l}\text { Частка державних витрат на студента (вища } \\
\text { освіта) до ВВП на одного громадянина (\%) }\end{array}$ & 27 \\
\hline \multicolumn{3}{|c|}{ Соціальні показники } \\
\hline $\mathrm{Sh}_{\text {lov } 20}$ & Частка найбіднішої квінтильної групи у доходах & 3 \\
\hline $\mathrm{Sh}_{\text {hig } 20}$ & Частка найбагатшої квінтильної групи у доходах & 4 \\
\hline $\mathrm{k}_{\mathrm{dif}}$ & Квінтильний коєфіцієнт диференціації доходів & 5 \\
\hline $\mathrm{Sh}_{\text {Pov }}$ & $\begin{array}{l}\text { Частка населення за межею бідності (частка тих, } \\
\text { хто споживає на суму, меншу } 1,9 \text { дол. США) }\end{array}$ & 31 \\
\hline \multicolumn{3}{|c|}{ Фінансові показники } \\
\hline $\mathrm{D}_{\mathrm{Ext} / \mathrm{GNI}}$ & $\begin{array}{l}\text { Частка зовнішнього боргу у валовому націо- } \\
\text { нальному доході (\%) }\end{array}$ & 7 \\
\hline $\mathrm{D}_{\text {Ext }}$ & Обсяг зовнішнього боргу (дол. США) & 8 \\
\hline $\mathrm{T} / \mathrm{Y}$ & Частка податків на доходи у ВВП (\%) & 11 \\
\hline $\mathrm{G} / \mathrm{Y}$ & Частка видатків у ВВП (\%) & 12 \\
\hline $\mathrm{D}_{\mathrm{G}} / \mathrm{Y}$ & Частка державного боргу у ВВП (\%) & 18 \\
\hline $\mathrm{Cr}_{\mathrm{IMF}}$ & Використовувані кредити МВФ (у дол. США) & 20 \\
\hline
\end{tabular}


Продовження табл. 1

\begin{tabular}{|c|l|c|}
\hline \multicolumn{3}{|c|}{ Монетарні показники } \\
\hline$\pi_{\mathrm{CPI}}$ & Темп інфляції за індексом споживчих цін (\%) & 10 \\
\hline $\mathrm{q}_{\mathrm{USD}}$ & Курс валюти (грн за дол. США) & 13 \\
\hline$\pi_{\mathrm{defl}}$ & Темп інфляції за показником дефлятора ВВП (\%) & 14 \\
\hline $\operatorname{Res}_{\mathrm{CB}}$ & Резерви національного банку (в дол. США) & 19 \\
\hline $\mathrm{i}^{\mathrm{r}}$ & Реальна процентна ставка (\%) & 21 \\
\hline $\mathrm{i}_{\mathrm{dep}}$ & Процентна ставка за депозитами (\%) & 22 \\
\hline $\mathrm{g}_{\mathrm{BM}}$ & Зростання широких грошей (\%) & 23 \\
\hline \multicolumn{1}{|l|}{ Показники ресурсного потенціалу } \\
\hline $\mathrm{L}$ & Робоча сила (осіб) & 24 \\
\hline $\mathrm{u}_{\mathrm{ILO}}$ & $\begin{array}{l}\text { Рівень безробіття, за міжнародними методиками } \\
\text { оцінювання (\%) }\end{array}$ & 25 \\
\hline $\mathrm{u}^{\prime}$ & $\begin{array}{l}\text { Рівень безробіття за оцінкою національних органів } \\
\text { статистики (\%) }\end{array}$ & 9 \\
\hline $\mathrm{N}$ & Населення країни (осіб) & 28 \\
\hline $\mathrm{n}$ & Темп зростання населення (\%) & 30 \\
\hline $\operatorname{migr}_{\mathrm{N}}$ & Чиста міграція (осіб) & 29 \\
\hline
\end{tabular}

Джерело: побудовано авторами самостійно.

Перевірка зв’язків між змінними відібраної бази даних 3 використанням методів регресійного аналізу дала можливість 3'ясувати, що найкращим для пояснення економічного зростання $\mathrm{g}_{\mathrm{Y}}$ (6) виявився такий перелік змінних: $\pi_{\mathrm{CPI}}(10), \mathrm{q}_{\mathrm{USD}}(13), \mathrm{S}_{\mathrm{N}} / \mathrm{Y}(15), \mathrm{Im} / \mathrm{Y}(16), \operatorname{Res}_{\mathrm{CB}}(19)$, $\mathrm{Cr}_{\mathrm{IMF}}(20), \mathrm{i}^{\mathrm{r}}$ (21). Характеристики якості регресійної моделі подано далі у табл. 2 .

Таблиия 2

\section{Технічні характеристики якості моделі}

\begin{tabular}{|c|c|c|c|c|c|c|c|c|}
\hline \\
\hline \multicolumn{9}{|c|}{$\begin{array}{rr}\text { Регрессионная статистика } \\
\text { Множествен } & 0,91\end{array}$} \\
\hline R-квадрат & 0,84 & & & & & & & \\
\hline Нормирован & 0,78 & & & & & & & \\
\hline Стандартная & 4,10 & & & & & & & \\
\hline Наблюдения & 28,00 & & & & & & & \\
\hline & & & & & & & & \\
\hline \multicolumn{9}{|c|}{ Дисперсионный анализ } \\
\hline & & SS & MS & $F$ & Значимость F & & & \\
\hline Регрессия & 7,00 & 1714,49 & 244,93 & 14,60 & 0,00 & & & \\
\hline Остаток & 20,00 & 335,48 & 16,77 & & & & & \\
\hline Итого & 27,00 & 2049,98 & & & & & & \\
\hline \multicolumn{4}{|c|}{ Коэффициентьідартная ои-статистикс } & Р-значение & Нижние 95\% & Верхние 95\% & Нижние 95,0\% & Верхние 95,0\% \\
\hline Y-пересечен & $-71,20$ & 12,39 & $-5,75$ & 0,00 & $-97,04$ & $-45,36$ & $-97,04$ & $-45,36$ \\
\hline $10 \pi \mathrm{CPI}$ Inflat & 0,01 & 0,00 & 4,86 & 0,00 & 0,00 & 0,01 & 0,00 & 0,01 \\
\hline 13 qUSD Offic & 0,32 & 0,16 & 1,92 & 0,07 & $-0,03$ & 0,66 & $-0,03$ & 0,66 \\
\hline $15 \mathrm{SN} / \mathrm{Y}$ Gross & 0,61 & 0,17 & 3,51 & 0,00 & 0,25 & 0,97 & 0,25 & 0,97 \\
\hline $16 \mathrm{Im} / \mathrm{Y} \mathrm{Impo}$ & 1,08 & 0,25 & 4,32 & 0,00 & 0,56 & 1,61 & 0,56 & 1,61 \\
\hline $19 \operatorname{Res} C B$ Totá & 0,00 & 0,00 & 4,55 & 0,00 & 0,00 & 0,00 & 0,00 & 0,00 \\
\hline 20 CrIMF Use & 0,00 & 0,00 & $-2,77$ & 0,01 & 0,00 & 0,00 & 0,00 & 0,00 \\
\hline 21 ir Real inte & 0,29 & 0,05 & 6,42 & 0,00 & 0,20 & 0,39 & 0,20 & 0,39 \\
\hline
\end{tabular}

Джерело: побудовано авторами самостійно. 
Наведені технічні характеристики моделі свідчать про таке:

- спостерігається висока якість моделі, оскільки подані у ній змінні пояснюють економічне зростання на $84 \%\left(\mathrm{R}^{2}=0,84\right)$;

- імовірність того, що змінні моделі відібрано неправильно, $\epsilon$ нульовою (F-критерій = 0), тобто змінні відібрано правильно;

- вплив усіх змінних моделі на економічне зростання, репрезентований коєфіцієнтами при змінних, $є$ значущим (Р-значення $<0,1$ для всіх змінних).

Попри високі технічні характеристики моделі, знаки при коєфіцієнтах («+» чи «-») засвідчують суперечливі й такі, що важко пояснюються 3 позицій макроекономічної теорії, впливи. До таких суперечливих, з огляду на знаки при коєфіцієнтах, впливів змінних, зокрема, належить таке:

- виявлено сильний позитивний вплив інфляції на економічне зростання (коєфіцієнт при $\left.\pi_{\mathrm{CPI}}=+0,01\right)$, попри традиційний підхід до надмірної інфляції як до чинника з гальмівним впливом щодо зростання;

- ідентифіковано сильний позитивний вплив від збільшення частки імпорту у ВВП на економічне зростання (коєфіцієнт при $\mathrm{Im} / \mathrm{Y}=+1,08$ ), попри традиційний підхід до імпорту як до явища «вилучення» 3 економічного кругообігу, а отже, як до фактора, що має гальмувати зростання;

- виявлено сильний позитивний вплив реальної ставки процента на економічне зростання (коєфіцієнт при $\left.\mathrm{i}^{\mathrm{r}}=+0,29\right)$, попри уявлення про стримуючий вплив збільшення процентної ставки на інвестиції, а відтак, і на економічне зростання.

3'ясовані суперечності між характером (напрямком) впливу показників, за якісною регресійною моделлю, з одного боку, та за логікою теоретичних пояснювальних моделей щодо цих впливів - 3 іншого, дають підстави принаймні для таких припущень:

- впливи економетрично відібраних показників є складнішими, ніж це передбачено в макроекономічній теорії;

- імовірно, що ці впливи $є$ нелінійними, перехресними й такими, що грунтуються на багаторівневих залежностях.

Якщо наші припущення правильні, то в цьому випадку для моделювання та пояснення економічного зростання доречним $\epsilon$ використання інструментарію Data Science 3 побудовою штучної нейронної мережі.

Модель штучної нейронної мережі створено в середовищі Deductor. Результати побудови мережі подано на рис. 2.

Граф нейронної мережі засвідчує нелінійний вплив сімох змінних на економічне зростання, їх перехресну взаємодію та формування певних «вузлів» такої взаємодії. Найсильнішим, при формуванні одного 3 «вузлів», виявився вплив реальної процентної ставки та використовуваних кредитів МВФ, а найслабшим - вплив 
частки імпорту у ВВП. При формуванні іншого «вузла», вплив усіх змінних виявився приблизно однаковим.

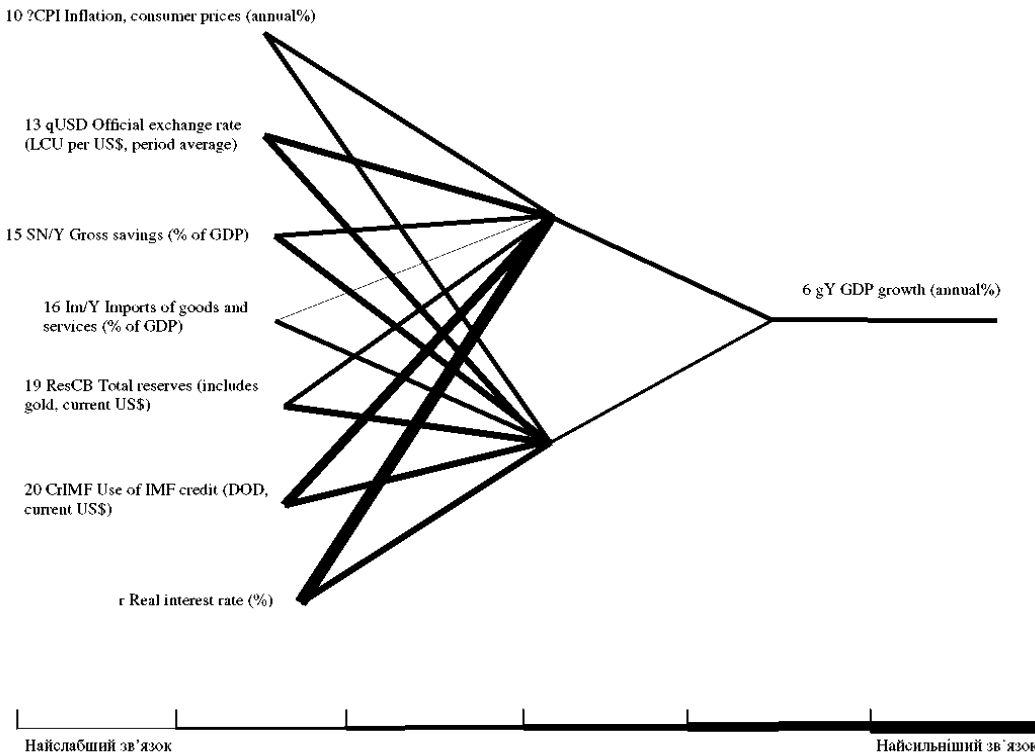

\section{Рис. 2. Граф нейронної мережі, що ілюструс зв'язок відібраних змінних та економічного зростання}

Джерело: побудовано авторами самостійно.

Перевірка нейронної мережі на тестовій вибірці подана на рис. 3.

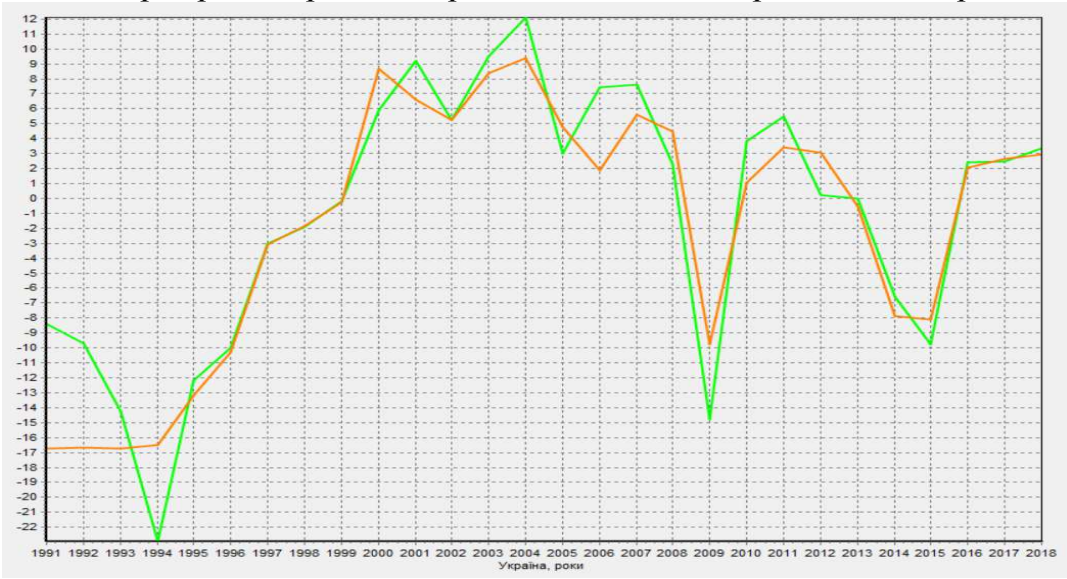

Рис. 3. Перевірка якості нейронної мережі

Джерело: побудовано авторами самостійно. 
Рис. 3 ілюструє ступінь наближення фактичних та змодельованих 3 використанням нейронної мережі значень економічного зростання. На тестовій вибірці (2017 - 2018 рр.) похибка прогнозу склала в середньому менше $1 \%$. Це свідчить про високу якість нейронної мережі та можливість iii використання для прогнозування й аналізу.

Перевірка зв'язків між змінними для побудови нейронної мережі, що моделює рівень диференціації доходів, за коєфіцієнтом Джинні, методами регресійного аналізу виявила найкращі змінні для пояснення. Такими змінними стали: $\mathrm{u}^{\prime}(9), \pi_{\mathrm{CPI}}(10), \mathrm{q}_{\mathrm{USD}}(13), \mathrm{S}_{\mathrm{N}} / \mathrm{Y}(15), \mathrm{i}^{\mathrm{r}}(21), \mathrm{i}_{\mathrm{dep}}(22), \mathrm{n}(29)$.

Характеристики якості регресійної моделі зв'язку між коєфіцієнтом Джинні та іншими змінними подано далі у табл. 3.

Таблиия 3

\section{Технічні характеристики моделі}

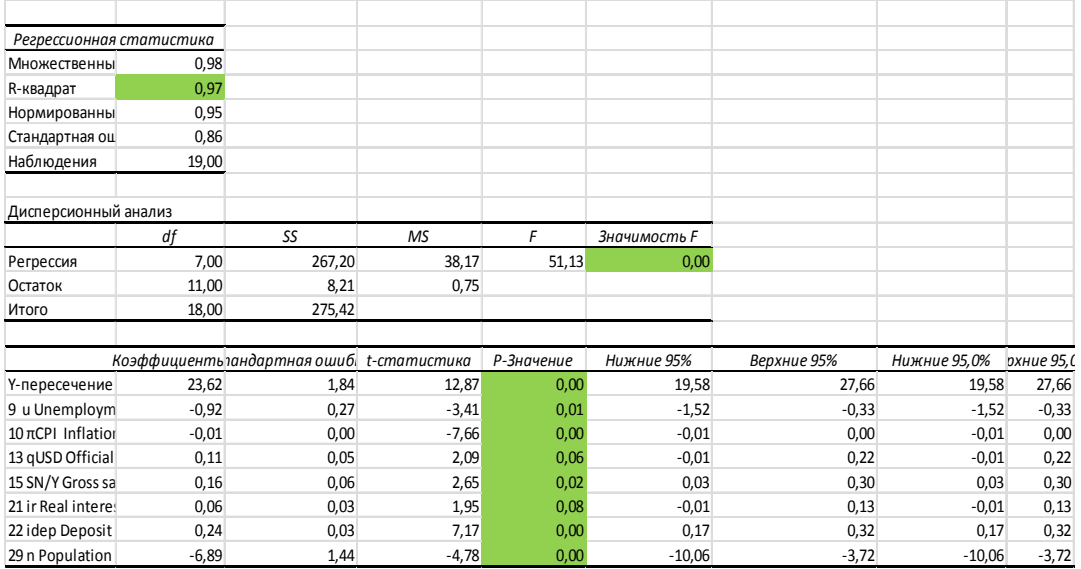

Джерело: побудовано авторами самостійно.

Наведені технічні характеристики моделі у цьому випадку свідчать про таке:

- спостерігається дуже висока якість моделі, оскільки подані у ній змінні пояснюють диференціацію доходів, оцінену коєфіцієнтом Джинні на 97\% $\left(\mathrm{R}^{2}=0,97\right)$;

- фактично відсутня ймовірність того, що змінні моделі відібрано неправильно, (F-критерій = 0), тобто змінні відібрано правильно;

- вплив усіх змінних моделі на диференціацію доходів, репрезентований коєфіцієнтами при цих змінних, $€$ значущим (Р-значення $<0,1$ для всіх змінних).

За знаками коєфіцієнтів при змінних («+» чи «-»), тобто за характером залежностей, вплив на диференціацію доходів відібраних змінних виглядає ще більш контроверсійно, ніж у попередній моделі економічного зростання. Характер впливу лише однієї змінної (з 7-ох) 
може бути пояснений принаймні «з позицій здорового глузду». Йдеться про обернений зв'язок між темпом зростання населення та диференціацією доходів (коєфіцієнт при $\mathrm{n}=-6,89$ ). Така обернена залежність може пояснюватися хоча б тим, що зменшення темпу зростання населення, за інших однакових умов, збільшує частку людей старшого віку, доходи яких зазвичай $є$ меншими. Виявлений обернений зв'язок між диференціацією доходів та двома змінними - безробіттям (коєфіцієнт при $\left.\mathrm{u}^{\prime}=-0,92\right)$ й інфляцією (коєфіцієнт при $\left.\pi_{\mathrm{CPI}}=-0,01\right)-$ суперечить теорії. Адже усталеним $є$ твердження про інфляцію як чинник збільшення розшарування громадян у суспільстві та про безробіття, що спричиняє зростання бідності. Позитивний вплив девальвації на збільшення диференціації доходів (коєфіцієнт при $\mathrm{q}_{\mathrm{USD}}=+0,11$ ) може бути поясненим особливостями масового зберігання заощаджень українськими громадянами у валюті інших країн. Зв'язки ж диференціації доходів ще з трьома змінними - реальною ставкою проценту (коєфіцієнт при $\left.\mathrm{i}^{\mathrm{r}}=+0,24\right)$, ставкою проценту за депозитами (коєфіцієнт при $\mathrm{i}_{\mathrm{dep}}=-0,01$ ) та часткою заощаджень у ВВП (коєфіцієнт при $\left.\mathrm{S}_{\mathrm{N}} / \mathrm{Y}=+0,16\right)-\epsilon$ найбільш утаємниченими й мало зрозумілими. Саме вони, на наш погляд, найбільшою мірою виявляють невизначеність у сенсі того, що не підлягає поясненню, усвідомленню та очікуванню.

Усі зазначені особливості моделі диференціації доходів дають підстави припускати нелінійність та багаторівневість залежностей, отже - доцільність використання в моделюванні інструментарію штучних нейронних мереж.

Ілюстрація моделі штучної нейронної мережі, побудованої в середовищі Deductor, подана на рис. 4.

Граф нейронної мережі на рис. 4 засвідчує нелінійний, перехресний вплив сімох змінних на диференціацію доходів та факт формування «вузлів» взаємодії. Найсильнішим з усіх впливів виявився вплив частки національних заощаджень у ВВП при формуванні другого «вузла». При формуванні першого «вузла» взаємодії найсильнішим виявився вплив курсу національної валюти. Натомість, темп приросту населення здійснював у обох «вузлах» найслабший вплив на диференціацію доходів.

Перевірка якості нейронної мережі на тестовій вибірці подана на рис. 5.

На рис. 5 ілюстровано високий ступінь наближення фактичних та змодельованих з використанням нейронної мережі значень диференціації доходів, яку оцінено за коєфіцієнтом Джинні. На тестовій вибірці (2017 - 2018 рр.) похибка прогнозу склала, в середньому, менше 1\%. Це свідчить про дуже високу якість нейронної мережі та про те, що вона може використовуватися для прогнозування, аналізу й прийняття управлінських рішень. 


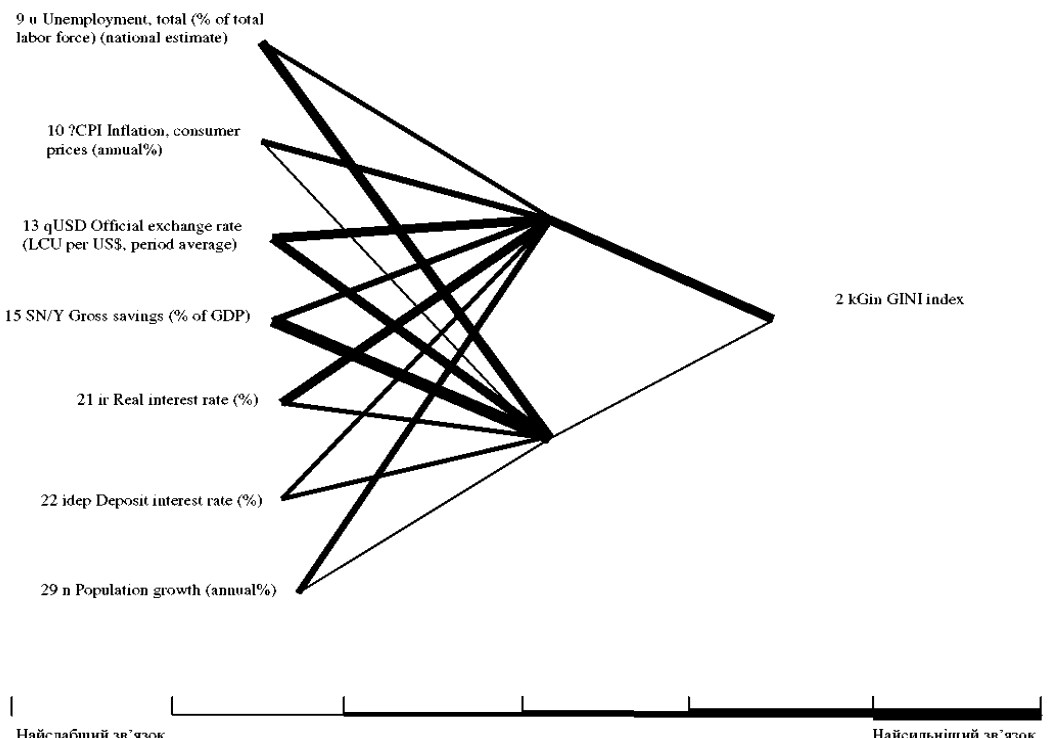

Найслабший зв' язок

Найсильнішнй зв'язок

Рис. 4. Граф нейронної мережі зв'язку між відібраними змінними та диференціацісю доходів, за коєфіціснтом Джинні Джерело: побудовано авторами самостійно.

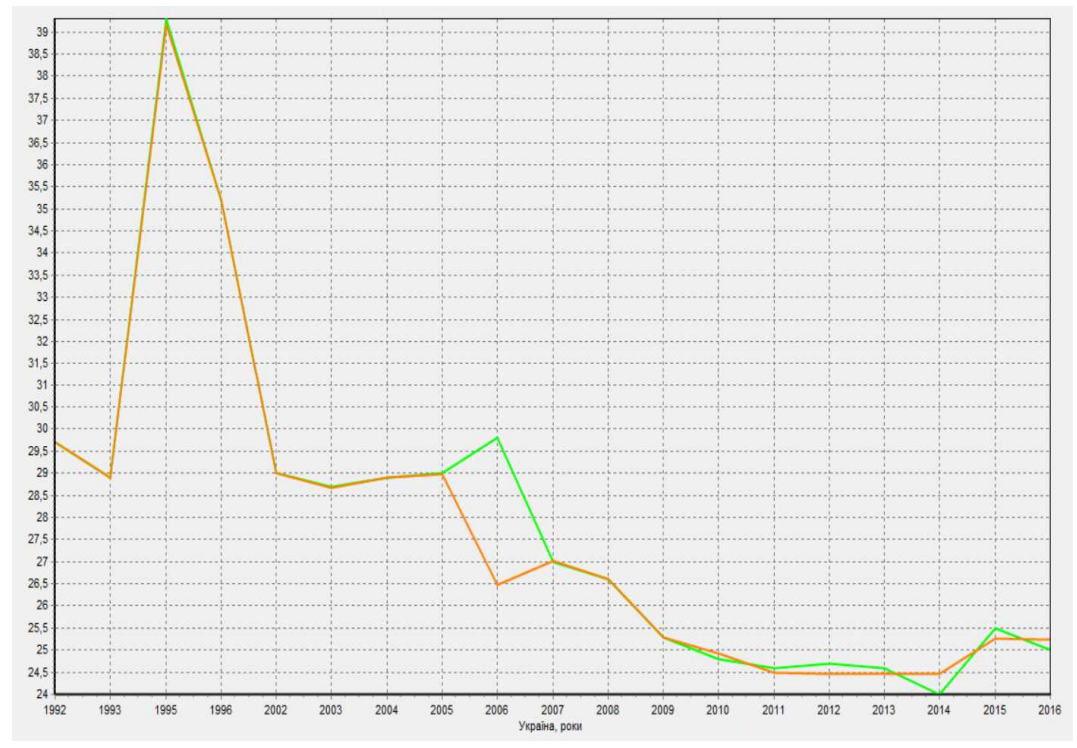

Рис. 5. Перевірка якості нейронної мережі

Джерело: побудовано авторами самостійно. 
Узагальнюючи результати використання інструментарію Data Science в аналізі на макроекономічному рівні, ми робимо такі проміжні висновки:

- у процесі економетричного аналізу макроекономічних явищ економічного зростання та диференціації доходів - виявлено суттєві, але «непояснювані» й непередбачені зв'язки (залежності). За нашим припущенням, у цьому виявляється економічна неочевидність, так звані «приховані смисли», отже, економічна невизначеність;

- використання інструментарію Data Science дає можливість робити висновки про фактично існуючі залежності та якісно прогнозувати майбутній перебіг подій навіть у випадку існування нечітко ідентифікованих впливів. Попри нечітку ідентифікацію, автоматичне формування «вузлів» взаємодії між змінними засвідчує існування складних залежностей.

Метою цього дослідження є пошук відповіді на питання, в який спосіб використання інструментарію Data Science може сприяти прийняттю більш обгрунтованих управлінських рішень. Зрозуміло, що на макроекономічному рівні йдеться про рішення органів публічної влади й про так званих національних регуляторів. Розглянутий нами приклад може використовуватися в контексті принаймні таких рекомендацій щодо управлінських рішень:

- прогнозування динаміки змінних, які можуть бути метою впливу національних регуляторів (економічне зростання та диференціація доходів $\epsilon$ саме такими цільовими показниками), не може спиратися лише на очевидні фактори впливу. В прогнозуванні мають враховуватися нелінійні багаторівневі зв'язки між змінними;

- для обгрунтування конкретних результатів (відгуків) імпульсів, що йдуть в економіку від органів публічної влади, доцільно формувати більш повне й досконале уявлення про трансмісію імпульсів. Остання охоплює як очевидні, так і неочевидні елементи трансмісії, тобто зв'язки між змінними.

Обидві рекомендації щодо вдосконалення управлінських рішень на макроекономічному рівні можуть досягатися 3 використанням інструментарію Data Science.

Актуальність використання Data Science на мікроекономічному рівні - рівні окремих економічних суб'єктів - у сучасній українській економіці визначається принаймні такими обставинами. По-перше, спостерігається низька ефективність інвестицій загалом та інвестицій у банківську сферу зокрема. Тому виникає потреба аналізу та використання таких інструментів дослідження, які б сприяли виявленню не лише очевидних, а й глибинних, прихованих (неочевидних) причин низької ефективності. По-друге, при прийнятті управлінських рішень, наразі, фактично використовується мізерна частка всієї інформації, пов'язаної 
3 діяльністю окремих економічних суб' єктів. За експертним оцінюванням, ця частка становить лише $0,5 \%$. Тому розширення бази досліджуваних даних може сприяти більш обгрунтованій відповіді на питання «Чому ефективність $€$ низькою та яким чином підвищити віддачу від інвестицій» для кожного конкретного випадку.

Практичне використання технологій Data Science на мікроекономічному рівні ми ілюструватимемо на конкретному прикладі, який дає можливість виявити переваги цього інструментарію.

Об'єктом дослідження став конкретний банк", що входить до 10-и топбанків України у 2018 році. Завданням (метою) аналізу став пошук та обгрунтування способів підвищення ефективності інвестицій. Ішлося про медіа-інвестиції у рекламу банківських послуг. Метою оптимізації інвестиційних витрат на рекламу було визначено збільшення продажів банківських послуг та зростання дохідності (прибутковості) банку, тобто підвищення ROMI (Return of Marketing Investments).

Логіка модельної конструкції у цьому випадку була такою, яка представлена на рис. 6 і відображає, так звану «воронку продажів» банку через один з каналів продажів - кол-центр.

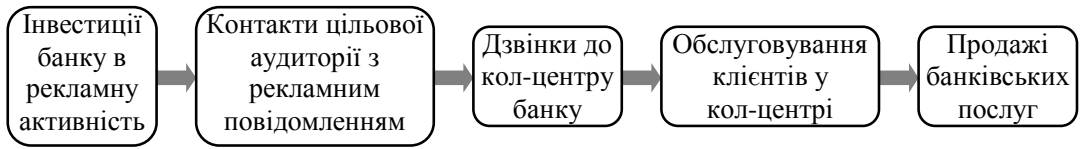

Рис. 6. Логіка модельної конструкції при обгрунтуванні рішень для комерційного банку з використанням інструментарію Data Science

Джерело: побудовано авторами самостійно.

Інформаційна база дослідження охоплювала дані за більше ніж 30-ма показниками у різних часових проміжках, що, за джерелом (походженням) даних, поділялися на три групи, а саме:

- показники діяльності банку щодо «воронки продажів»;

- показники щодо рекламної активності банку та його конкурентів;

- дані про макроекономічне та соціальне середовище підприємницької діяльності.

Використання перших двох груп джерел даних у цьому дослідженні $\epsilon$ апріорі зрозумілим. Адже йдеться про проєкт використання рекламної активності для збільшення продажів банківських продуктів. Третя група джерел потребує детальнішого пояснення.

У період економічного спаду внаслідок політичної кризи та початку російсько-української війни у $2014-2015$ рр. банківський сектор

\footnotetext{
* Через зобов' язання про нерозголошення інформації назва банку не оприлюднюється.
} 
загалом і даний конкретний банк зокрема зазнали суттєвих втрат від змін макроекономічного середовища. У цей період відбулася девальвація національної валюти у 3-4 рази (з 8 до 26 - 32 грн за дол. США), значно скоротився індекс довіри до банків [19], депозити у валютах інших країн зменшилися на $57 \%$, депозити в гривнях - на $8 \%$, кредити на $38 \%$ [20]. Тому зрозуміло, що рекомендації для банку в 2018 р. мали спиратися на припущення про існування певних трендів очікувань та реакцій споживачів банківських послуг, що сформувалися у 2014 2015 рр. Необхідним було й урахування нових макроекономічних тенденцій економічного зростання у 2016 - 2018 рр.

Акцентування уваги на інвестуванні у рекламну діяльність визначалося тим, що під час кризового спаду національної економіки рекламна діяльність банків у країні мінімізувалася. У медійному просторі була лише інформація про декілька великих банків, які намагалися підтримувати довіру українців [21; 22]. Досліджуваний банк інвестував лише в одну рекламну кампанію у 2016 р., але рівень реакції був невисоким. Тому кампанія була згорнута, а медіареклама не використовувалася впродовж 2-х років.

При здійсненні рекламної кампанії досліджуваного банку постала загальна бізнес-задача: інвестування у медіарекламу та розробка медійної стратегії у такий спосіб, який би спричинив максимальний відгук у вигляді дзвінків до кол-центру банку. Конкретним завданням інвестиційного проєкту стало формування «найкращого медіаміксу» 3 різних рекламних інструментів за оптимального розподілу рекламного бюджету. Критерієм оптимізації визначено досягнення позитивної віддачі від інвестицій (ROI). Відповідно, мета Data Science-проєкту полягала в дослідженні, моделюванні та прогнозуванні завантаженості кол-центру банку у відповідності з рекламною діяльністю банку в засобах масової інформації. При цьому використовувався Data Mining підхід і технології машинного навчання.

Проєкт здійснювався згідно 3 міжгалузевим стандартом обміну даними CRISP-DM [23] - аналітичною моделлю, що дістала найбільше використання в подібних дослідженнях [24]. Для створення необхідної бази даних зібрано інформацію щодо показників попередніх рекламних кампаній банку впродовж 2013 - 2016 рр., а також дані щодо соціально-економічного розвитку. Була врахована класична практика медіапланування (врахування частки голосу в медіаканалі, частоти контактів зі споживачами та рівня охоплення цільової аудиторії). Проте основна увага була зосереджена на бізнес-показниках (дзвінках до колцентру банку, продажах послуг банку й рівні конверсії). У такий спосіб був розроблений новий інтегральний підхід для прийняття рішень, що базується на Data Science, технологіях машинного навчання й максимальному використанні даних. 
За допомогою програмного забезпечення Excel та R-Studio була побудована економетрична модель 3 ключовою метрикою «Вхідні дзвінки до кол-центру». Для реалізації підходу використовувалися математичні методи аналізу й прогнозування на основі бази даних 3 історичними даними самого банку, медіа-агенції та зовнішнього середовища (соціальних і макроекономічних показників). До моделі були додані параметри, які впливали на конверсію (трансмісійний механізм) від медіа-активності до дзвінків, а також від дзвінків до замовлень та продажів. Параметри було оптимізовано саме для отримання найкращого коєфіцієнту конверсії.

Загальна економетрична модель поділялася на підмоделі для моніторингу бізнес-завдань на кожному конкретному етапі, а саме:

1) модель короткострокового щотижневого планування, що дозволяло фіксувати та оцінювати вплив реклами на досягнення результатів діяльності банку (як позитивних, так і негативних) у будьякий момент часу;

2) модель тактичного планування, що дозволяє планувати погодинну інтенсивність трафіку кол-центру банку у відповідь на зміни медіа-активності. Зокрема, було виявлено залежність між вхідними дзвінками потенційних клієнтів банку до кол-центру та обсягом розміщеної реклами на телебаченні протягом дня. Це дало можливість визначити ефективність телевізійної активності в кожну годину дня і впродовж тижня. Модель створила підгрунтя для операційної оптимізації роботи кол-центру банку.

Модель множинної регресії 3 більш ніж 30 факторами зі щоденними та погодинними характеристиками має такий вигляд:

Calls_by_hours $=$ hours_coefficient $\times$ day_coefficient $\times\left(\right.$ Constant $+\mathrm{a}_{1} \times$ $\times$ Adstock $\left(\mathrm{TV}_{1}\right)+\mathrm{a}_{2} \times \operatorname{Adstock}\left(\mathrm{TV}_{2}\right)+\ldots+\mathrm{a}_{\mathrm{n}} \times \operatorname{Adstock}\left(\mathrm{TV}_{\mathrm{n}}\right)+\mathrm{b} \times$ $\times$ Radio_activity $+c_{i} \times$ billboards_i $+d_{i} \times$ Integrated_economic_indicator_i),

де Calls_by_hours - кількість дзвінків до кол-центру 3 погодинною розбивкою; hours_coefficient - ефективність телевізійної активності за певну годину; day_coefficient - ефективність телевізійної активності за певний день тижня; Constant - базовий (органічний) рівень дзвінків за певну годину; $a_{i}$ - ефективність телевізійної активності і-го виду, i = 1...n; Adstock - відповідно, миттєвий, тривалий і відстаючий ефект впливу реклами на телебаченні на поведінку покупців банківських послуг упродовж певного часу; Adstock $(\mathrm{TV})_{\mathrm{t}}=\mathrm{TV}_{\mathrm{t}}+\mathrm{a} \times \operatorname{Adstock}(\mathrm{TV})_{\mathrm{t}-1}$; b - ефективність активності на радіо; Radio_activity - активність на радіо; с - ефективність активності в зовнішній рекламі і-го виду, $\mathrm{i}=1 \ldots \mathrm{n}$; billboards_i - активність у зовнішній рекламі i-го виду, $\mathrm{i}=1 \ldots \mathrm{n}$; Integrated_economic_indicator - інтегральний показник, який одночасно віддзеркалює рівень ВВП, доходів та динаміку банківських продуктів. 
Модель $є$ достатньо складною, з технічного погляду, тому що втілює поєднання субмоделей з урахуванням перебігу подій упродовж кожного дня і кожного тижня. Базою для розрахунків стали дані 3 джерела даних*. Ці ж дані використано для побудови рисунків, поданих далі.

Технічні характеристики однієї з субмоделей загальної моделі подано у табл. 4.

Таблиия 4

Технічні характеристики субмоделі

\begin{tabular}{|l|l|l|l|l|}
\hline Indicator & Coefficient & Stand. Error & t-statistics & P-value \\
\hline Constant & 19,78 & 5,97 & 3,31 & 0,0017 \\
\hline Economic indicator & $-3,82$ & 0,08 & $-50,44$ & 0,0000 \\
\hline Billboard & 32,98 & 0,42 & 77,77 & 0,0000 \\
\hline Radio & 65,24 & 4,45 & 14,67 & 0,0000 \\
\hline TV1 & 158,53 & 0,75 & 211,77 & 0,0000 \\
\hline TV2 & 140,34 & 1,08 & 130,09 & 0,0000 \\
\hline TV3 & 178,96 & 1,45 & 123,61 & 0,0000 \\
\hline TV4 & 110,27 & 7,70 & 14,32 & 0,0000 \\
\hline Multiple R-squared & 0,97 & & Adjusted R-squared & 0,97 \\
\hline F-statistics & 11894,423 & & p-value & 0,0000 \\
\hline
\end{tabular}

Джерело: розроблено авторами самостійно.

Основними критеріями технічної оптимізації моделі були: підвищення $\mathrm{R}^{2}$, уникнення автокореляції, гетероскедастичності та мультиколінеарності. Досягнуті результати моделювання є такими: модель оцінює вплив факторів з вірогідністю на рівні $97 \%\left(\mathrm{R}^{2}=97 \%\right)$, існує гомоскедастичність (тобто відсутня гетероскедастичність), відсутня автокореляція.

Побудована економетрична модель дозволила визначити вплив кожного значущого фактора та розробити рекомендації щодо найбільш ефективного використання медіаресурсів. Основні п'ять рекомендацій $є$ такими.

По-перше, доцільність дотримання певної тривалості медіакампанії для мінімізації «ефекту зносу» на основі даних про те, що після досягнення так званої ваги флайту в X TRPs (основний показник вимірювання телевізійної активності), протягом Y тижнів, ефективність телевізійної активності знижується за рахунок ефекту зносу (рис. 7). Було рекомендовано підтримувати тривалість флайту на необхідному рівні TRPs для максимальної ефективності реклами.

По-друге, важливість здійснення ротації (заміни) роликів під час флайту для додаткового зростання кількості дзвінків до кол-центру

\footnotetext{
* Внутрішня база даних українського банку (конфіденційна інформація).
} 
банку та часткового зменшення ефекту зносу. Висновок зроблено на підставі оцінки того, що заміна рекламного оголошення дозволяє збільшити кількість дзвінків на $19 \%$, але це не компенсує ефекту зносу. 3 урахуванням наявності коротких флайтів рекомендовано використовувати різні рекламні матеріали.

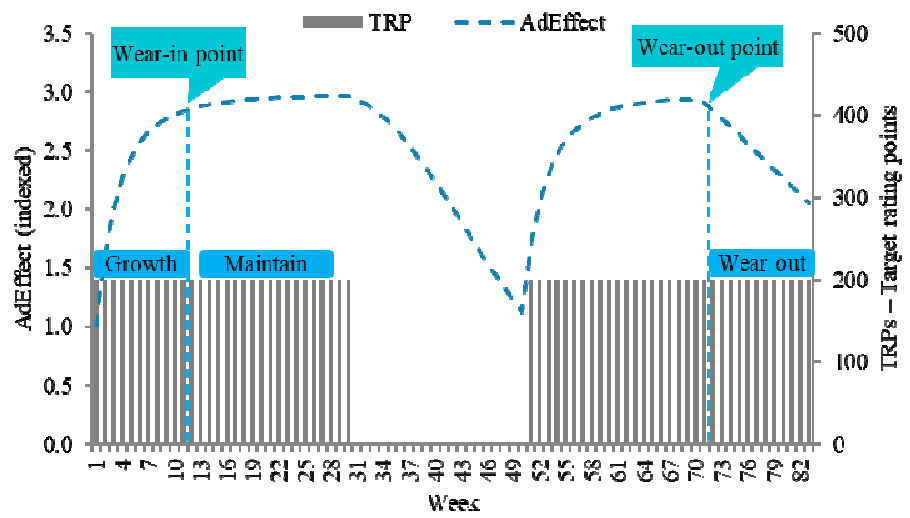

Рис. 7. «Wear-out» ефект («ефект зносу» рекламного повідомлення) Джерело: розроблено авторами самостійно.

По-третє, доцільність розміщення виключно конкретних медіаресурсів, наприклад, лише ролика X" (рис. 8), уникаючи використання інших. 3'ясовано, що, враховуючи ціну, розміщення реклами, наприклад, з $\mathrm{X}^{\prime \prime}$ роликом, $\epsilon$ найбільш ефективним. Тому для реалізації KPIs рекомендовано 100\% використання лише певної версії відеореклами.

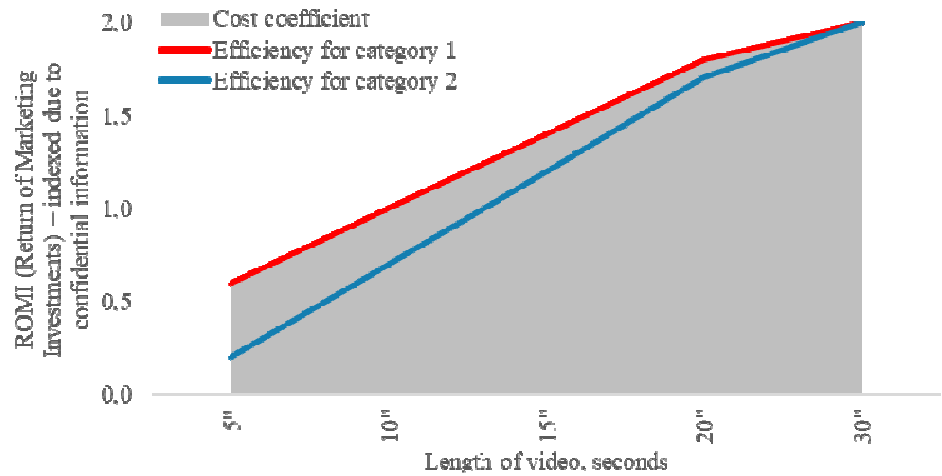

Рис. 8. Ефективність різної тривалості відеоматеріалів

Джерело: розроблено авторами самостійно. 
По-четверте, обгрунтованість додаткової активності в інших (окрім уже застосованих) каналах комунікації за останні тижні телевізійної кампанії для додаткового охоплення потенційних клієнтів та зростання кількості дзвінків до кол-центру банку (рис. 9). Доведено, що інший медіаканал допомагає генерувати додаткові дзвінки, а одночасне застосування декількох каналів комунікації дає приріст дзвінків за кожен день активності в розмірі $+20 \%$ порівняно з дзвінками, забезпеченими лише однією телевізійною рекламою.

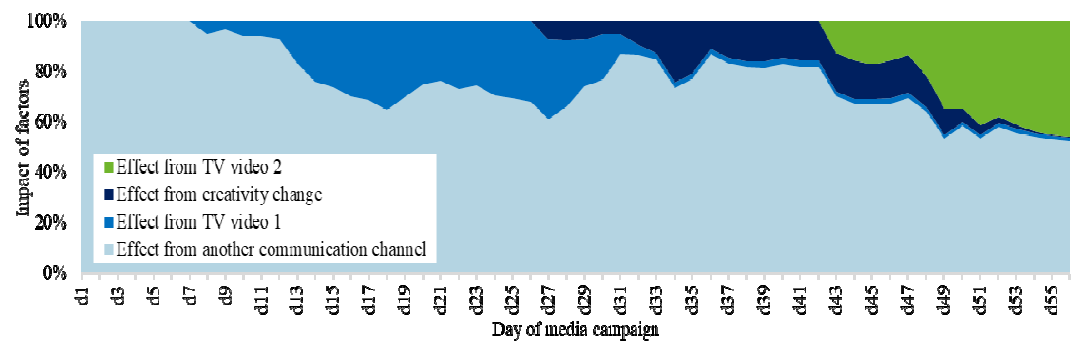

Рис. 9. Декомпозиція моделі з застосуванням різних каналів комунікації

Джерело: розроблено авторами самостійно.

По-п’яте, доцільність втілення тактичних організаційних змін, а саме:

a) обмеження розміщення реклами у вихідні та святкові дні на телебаченні, що підтверджується графіком (рис. 10);

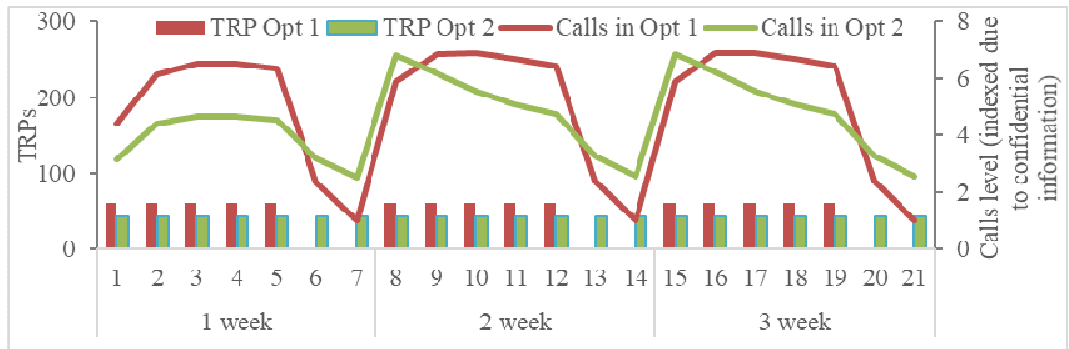

Рис. 10. Дзвінки до кол-центру банку за різних сценаріїв розподілу телевізійної активності протягом тижня

Джерело: розроблено авторами самостійно.

б) рівномірний розподіл активності впродовж дня, за обмеження частки вечірнього розміщення. Доведено, що ефективність розміщення у вечірній час є нижчою, ніж денна та ранкова, а ефект вечірнього прайм-тайму виявився таким самим, як і для денного розміщення реклами (рис. 11). 


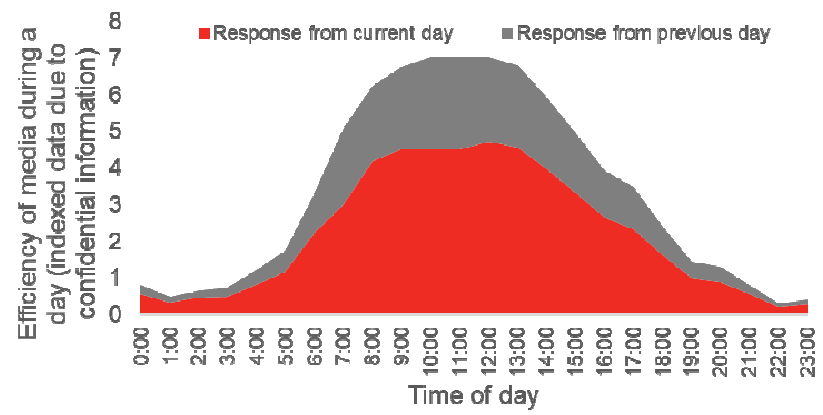

\section{Рис. 11. Кількість дзвінків з рівномірним розподілом рейтингів на телебаченні протягом дня (погодинна ефективність телевізійної активності)}

Джерело: розроблено авторами самостійно.

Такі рекомендації не можна приймати одночасно для всіх компаній на ринку, оскільки результати - це сукупність багатьох факторів та умов, які формуються кожного разу. Це вимагає індивідуального підходу в кожному конкретному випадку.

Основними досягнутими результатами Data Science-проєкту 3 використанням технологій машинного навчання стали рекомендації щодо оптимізації інвестицій у рекламу, з огляду на показники бізнесової діяльності банку. Ці рекомендації, як уже зазначено, стосувалися формування найбільш ефективного поєднання (міксу) засобів масової інформації, найкращого періоду (часу доби чи дня тижня) для використання ЗМІ з метою рекламування діяльності банку, тривалості використання окремих інструментів реклами тощо. Були досягнуті такі конкретні економічні результати:

- вартість рекламної кампанії зменшено на 14\%;

- забезпечено на 58\% вищий рівень конверсії (ROMI) - зв'язку між інвестуванням у медіа-активність (рекламні кампаніі) та показниками діяльності банку-рекламодавця - порівняно зі стандартним ринковим рівнем конверсії;

- оптимізовано діяльність кол-центру банку та мінімізована ймовірність «втрати» дзвінків клієнтів через неможливість результативного контакту;

- розширено можливості прогнозування результатів рекламної кампанії банку: в середньому відхилення від прогнозу становило не більше $11 \%$ за щоденного прогнозування результатів та не більше $8 \%$ за щотижневого.

Показовим є те, що застосування Data Science сприяло виявленню суттєвого впливу чинників, які не можна було передбачити на початку дослідження та оцінити 3 використанням іншого інструментарію дослідження. Відтак, ми робимо висновок: Data Science $\epsilon$ результативним 
інструментом виявлення й оцінювання економічної невизначеності на мікроекономічному рівні.

\section{Висновки:}

За результатами дослідження можна зробити такі узагальнення:

1. Data Science $\epsilon$ інтегральною аналітичною наукою, що гарантує кращі результати при використанні великих баз даних та вирішенні проблеми ідентифікації й оцінювання економічної невизначеності.

2. Застосування інструментарію Data Science під час аналізу на макроекономічному рівні сприяло виявленню таких проявів невизначеності:

- суттєвого впливу раніше не ідентифікованих, тобто прихованих, «неповерхневих» факторів впливу (змінних);

- існування неприродних, тобто таких, що не пояснюються ні дедуктивним, ні емпіричним шляхом зв'язків;

- формування випадкових «вузлів» взаємодії між змінними, що можуть взаємно посилюватися або послаблюватися.

3. Застосування інструментарію Data Science під час аналізу на мікроекономічному рівні сприяло виявленню таких проявів невизначеності:

- вплив на процеси та явища факторів з інших суміжних сфер, які змінюють настрої, очікування, реакції;

- нелінійна конверсія (передання) імпульсів, яка, ймовірно, має свої оптимуми, або періоди найкращих значень;

- непередбачуваний розподіл одних і тих же подій у часі, коли йдеться про часові піки та спади активності;

- несподівані поєднання (мікси) подій та інструментів, які або посилюють, або послаблюють імпульси;

- покращення управлінських рішень на підставі застосованого інструментарію Data Science можуть стосуватися надійнішого прогнозування, відбору способів управлінського впливу, більш обгрунтованого тактичного планування, організаційних змін у взаємодії окремих підрозділів економічних суб'єктів тощо.

\section{Лimepamypa:}

1. Провост Ф., Фоусетт T. Data Science для бізнесу. Як збирати, аналізувати і використовувати дані / Пер. з англ. А. Дудченко. Київ : Наш Формат, 2019. 400 c.

2. Черняк О., Захарченко П. Інтелектуальний аналіз даних : підручник. Київ, 2014. 599 с.

3. Brin S. et al. Dynamic Itemset Counting and Implication Rules for Market Basket Data. N. Y. : ACM Press, 1997.

4. Einav L., Levin J. The Data Revolution and Economic Analysis. Stanford University and NBER. URL : http://www.fas.org/irp/agency/dod/ jason/data.pdf. 
5. Blum A., Hopcroft J., Kannan R. Foundations of Data Science. 2018. URL : http://deeplearning.net/tutorial/deeplearning.pdf.

6. Tom M. Mitchell Machine Learning. 1997. URL : http://profsite.um. ac.ir/ monsefi/machine-learning/pdf/Machine-Learning-Tom-Mitchell.pdf.

7. Чередніченко А. О., Шура Н. Застосування штучних нейронних мереж як дієвого механізму прийняття ефективних управлінських рішень. Глобальні та національні проблеми економіки. 2015. Вип. 4. C. 628-630.

8. Davis J. T., Episcopos A., Wettimuny S. Predicting direction shifts on Canadian-US exchange rates with artificial neural networks. International Journal of Intel ligent Systems in Accounting, Finance \& Management. 2010. №10. P. 83-96.

9. Armano G., Marchesi M., Murru A. A hybrid genetic-neural architecture for stock indexes forecasting. Information Sciences. 2005. №170(1). P. 3-33.

10. Tkacz G. Neural network forecasting of Canadian GDP growth. International Journal of Forecasting. 2001. №17. P. 57-69.

11. Vishwakarma K. P. Recognizing business cycle turning points by means of a neural network. Computational Economics. 1994. №7. P. 175-185.

12. Moshiri S., Cameron N. Neural network versus econometrics models in forecasting inflation. Journal of Forecasting. 2000. №19. P. 201-217.

13. Mitra S., Rupak T., Seema B., Mondal S. Artificial Neural Network Based Model for Forecasting of Inflation in India. Fuzzy Information and Engineering. 2016. Vol. 8. Issue 1. P. 87-100.

14. Hoog S. Deep Learning in (and of) Agent-Based Models: A Prospectus / Sander van der Hoog. 2017. URL : https://arxiv.org > pdf.

15. Chakraborty C., Joseph A. Machine learning at central banks / Chiranjit Chakraborty and Andreas Joseph. Bank of England. Staff Working Paper. 2017. №674. URL : https://www.bankofengland.co.uk > working-paper.

16. Офійний сайт бази даних Світового банку. URL : https://data. worldbank.org/indicator/.

17. Kravchuk R. S. Ukrainian Political Economy: The First Ten Years. Palgrave Macmillan. NY. 2002. 352 p. URL : https://books.google. com.ua/books?id=9BuBDAAAQBAJ\&pg=PA147\&lpg=PA147\&dq.

18. Офіційний сайт Державної служби статистики України. URL : http://www.ukrstat.gov.ua.

19. Сайт GFK Ukraine. URL : https://www.gfk.com/uk-ua/.

20. Сайт Національного банку України. URL : https://bank.gov.ua/.

21. Сайт Nielsen Ukraine. URL : https://www.nielsen.com/ua/uk/.

22. Сайт Індустріального телевізійного комітету. URL : http://itk.ua/en.

23. Brown M. S. What IT Needs To Know About The Data Mining Process. Forbes. 2015.

24. Shearer C. The CRISP-DM model: the new blueprint for data mining. 2000. №5. P. 13-22. 


\title{
ІНСТРУМЕНТАРІЙ ОЦННЮВАННЯ КОРПОРАТИВНОГО УПРАВЛІННЯ В АКЦІОНЕРНИХ ТОВАРИСТВАХ ЗА УМОВ ЕКОНОМІЧНОЇ НЕВИЗНАЧЕНОСТІ
}

\author{
Мігус Ірина Петрівна, \\ доктор економічних наук, професор, \\ професор кафедри управління фінансово-економічною безпекою, \\ ВНЗ «Університет економіки і права «КРОК», \\ ORCID: https://orcid.org/0000-0001-6939-9097
}

Анотація. Досліджено сучасні підходи до корпоративного управління, що дозволило уточнити його визначення. Вивчення зарубіжного та вітчизняного досвіду оцінювання корпоративного управління в акціонерних товариствах дало можливість 3'ясувати, що існуючі методики зазвичай не охоплюють якісні показники. А це в умовах економічної невизначеності негативно впливає на розвиток акціонерного товариства. Запропонована авторська методика передбачає оцінювання корпоративного управління за допомогою як якісних, так i кількісних показників. Якісні показники дозволяють оцінити таке: порядок скликання та проведення Загальних зборів акціонерів; порядок емісії акцій товариства; роботу Спостережної ради товариства; організацію роботи виконавчого органу товариства; розкриття інформації та іiі прозорість; контроль за фінансово-господарською діяльністю товариства. На підставі кількісних показників оцінюються: рентабельність капіталу; рентабельність власного капіталу; період окупності власного капіталу; коєфіцієнт фінансової незалежності; коєфіцієнт фінансової стабільності; прибуток на одну акцію; дивіденд на акцію; дивідендний вихід. Запропонований інструментарій сприятиме більш точному оцінюванню стану корпоративного управління в акціонерних товариствах за умов економічної невизначеності, що дозволить виокремити впливові фактори та удосконалити стратегію розвитку корпорацій.

Ключові слова: акціонерне товариство, корпоративне управління, акція, дивіденди, капітал, інструментарій, економічна невизначеність.

Розвиток підприємницької діяльності в умовах економічної невизначеності, що, крім іншого, пов'язано з інтеграцією України у світовий економічний простір, обумовлює активізацію процесів упровадження вітчизняними компаніями принципів та стандартів корпоративного управління. На користь зростаючої актуальності корпоративного управління для українських підприємств свідчать такі факти. По-перше, у країнах, які розвиваються, впровадження корпоративного управління $є$ однією 3 найважливіших передумов становлення публічного бізнесу, оскільки передбачає визнання загальних 
принципів управління підприємствами, чіткий та прозорий розподіл між основними зацікавленими особами (стейкхолдерами) повноважень і відповідальності за зростання вартості компанії. По-друге, якість корпоративного управління стає одним 3 найвагоміших чинників, що сприяє зменшенню невизначеності середовища функціонування i розвитку компаній унаслідок забезпечення інформаційної прозорості для всіх її стейхолдерів. По-третє, реалізація в компанії трансформаційних за характером проєктів стає поштовхом для якісних та масштабних змін у системі управління. А це практично неможливе без компетентної консалтингової допомоги.

У процесі приватизації і роздержавлення вітчизняних підприємств в Україні відбувається поступове формування інституту корпоративного управління. Зі становленням великого українського бізнесу, активізацією процесів корпоратизації, поширенням компаній холдингового типу суттєво актуалізувалася потреба у формуванні та впровадженні стандартів корпоративного управління.

Незважаючи на зростаючу на сучасному етапі необхідність застосування корпоративних принципів управління бізнесом в акціонерних товариствах, у більшості таких компаній в Україні корпоративне управління де-факто відсутнє або рівень його якості визнається низьким.

Тематична багатогранність і теоретична еклектичність питань ефективності корпоративного управління формують відповідний інформаційний простір дослідження. Засновники теорії корпоративного управління А. Берлі, Г. Мінз у монографії «Сучасна корпорація i приватна власність» [1] визначили два напрями дослідження: особливості управління в корпораціях з різним рівнем концентрації власності та відповідальність менеджменту перед стейкхолдерами. Значний сплеск досліджень системи корпоративного управління був пов'язаний 3 появою і розвитком агентської теорії. Праці видатних науковців М. Дженсена, Г. Демсеця, Б. Клейна, Е. Фамі значною мірою вплинули на формування принципів розподілу відповідальності й повноважень, становлення мотиваційної системи менеджменту корпорації [2].

Роль корпорації, як найскладнішої та найперспективнішої організаційної форми підприємництва, зростає в добу постіндустріального, інформаційного суспільства, оскільки саме вона $\epsilon$ найбільш конкурентоспроможним елементом висококонцентрованої та інтегрованої світової економіки.

Однак проблема пізнання сутності й функціональних і специфічних характеристик, що визначають місце корпорації в економіці країни та іiі відносини з економічними агентами, ще залишається невирішеною.

Низка проблем, пов'язаних зі специфікою корпоративного управління, обумовлена правовими факторами (розпорошення прав власності; ігнорування прав та інтересів індивідуального власника), 
економічними факторами (перевага кваліфікаційних знань і навичок менеджерів, ефект від'ємного синергізму, складність механізмів корпоративного контролю; асиметрія інформації), соціальними факторами (неузгодження економічних інтересів різних груп економічних агентів; детермінованість індивідуальної поведінки власника залежно від статутного внеску) та інституціональними факторами (зміна ролі корпорації як інституту глобальної економіки; зміна місця й ролі власника-акціонера; протиріччя між приватною та колективною основою корпорації) [2].

Вирішення згаданих проблем потребує створення ефективних механізмів взаємодії розрізнених інтересів корпорації як господарюючого суб'єкта і власників, вимагає гармонізації відносин власності та знаходження способів розв' язання протиріч між ними.

Корпорація (від лат. corporatio), за тлумаченням «Сучасного словника іноземних мов», - об'єднання, союз, що утворилися на основі професійних або станових інтересів. Найважливіші характерні ознаки корпорації як нової форми капіталістичних підприємств - концентрація величезних капіталів та надання вирішальної ролі найманим управлінцям визначили А. Берлі й Г. Мінз [1].

У більшості зарубіжних країн корпорації - це організаційні структури, які об'єднали необхідні ресурси для виробництва продукції і надання послуг населенню. Ця форма організації досить популярна в усіх країнах, оскільки:

- обмежує фінансовий ризик акціонерів унаслідок виключення за чинним законодавством їхньої відповідальності перед кредиторами товариства за межами капіталу, що розміщений в акціях;

- робить можливим залучення капіталу за рахунок випуску додаткової кількості акцій та емісії інших цінних паперів;

- продовжує діяльність навіть після зміни складу акціонерів;

- сприяє отриманню інвестицій на вигідних умовах;

- дає змогу власникам корпорацій успішно реалізувати стратегічні плани на засадах колективних інтересів.

Одним із головних чинників, який впливає на успішну діяльність корпорації, є можливість ії доступу до інвестиційного капіталу [1].

Визначення корпорації як акціонерного товариства $\epsilon$ загальноприйнятим та пріоритетним в економічній літературі. За усіх відмінностей у правових базах розвинутих країн основна розмежувальна лінія між корпоративним і некорпоративним секторами полягає у жорсткому розмежуванні власників та управлінців (менеджерів), а також обмеженні відповідальності [3].

В Україні, на жаль, формулювання поняття «корпорація» в чинному законодавстві суттєво відрізняється від загальноприйнятого у світовій практиці. Відповідно до Господарського кодексу України [4] «корпоративне підприємство створюється двома або більше засновниками 
за взаємним рішенням, діє на основі об’єднання майна та/або підприємницької або трудової діяльності засновників (учасників), загального управління справами, на основі корпоративних прав, у тому числі через органи, що ними створюються, участі засновників (учасників) в розподіленні доходів та ризиків підприємства».

Нещодавно прийнятий Закон «Про акціонерні товариства» [5] не розглядає акціонерне товариство як корпорацію, проте вводить таке поняття, як «корпоративне управління».

Поняття «корпоративне управління» широко використовується в західній економічній літературі й досить швидко запроваджується в Україні. Це пояснюється поширеною формою корпоративного господарювання і власності, необхідність управління нею та стрімким розвитком такої власності в Україні. Природа корпоративної власності не $\epsilon$ простою i, відповідно, корпоративне управління як категорія також являє собою складну систему економічних відносин, яка включає багато внутрішніх і зовнішніх елементів [2].

Одним із основоположних аспектів визначення принципів та механізмів підвищення ефективності корпоративного управління $\epsilon$ розуміння його сутнісного наповнення. Огляд підходів до трактування сутності корпоративного управління дозволяє констатувати існування, як мінімум, семи підходів до тлумачення такої дефініції (табл. 1).

Таблиия 1

Основні підходи до визначення поняття «корпоративне управління»

\begin{tabular}{|c|c|}
\hline Підхід & Поняття «корпоративне управління» \\
\hline $\begin{array}{l}\text { Нормативно- } \\
\text { правовий }\end{array}$ & $\begin{array}{l}\text { Система норм законодавства, нормативних положень і практики } \\
\text { господарювання у приватному секторі, що дозволяє компанії здійснювати } \\
\text { господарську діяльність та продовжувати своє функціонування, } \\
\text { нагромаджуючи довгострокову економічну вартість шляхом підвищення } \\
\text { вартості акцій }\end{array}$ \\
\hline $\begin{array}{l}\text { Організаційно- } \\
\text { правовий }\end{array}$ & $\begin{array}{l}\text { Управління організаційно-правовим оформленням бізнесу, оптимізацією } \\
\text { організаційних структур, побудовою внутрішньо- та міжфірмових } \\
\text { взаємозв’ язків компанії у відповідності до прийнятих цілей }\end{array}$ \\
\hline Реляційний & $\begin{array}{l}\text { Система взаємовідносин між інвесторами-власниками, менеджерами та } \\
\text { зацікавленими особами задля забезпечення ефективної діяльності товариства, } \\
\text { рівноваги балансу інтересів учасників корпоративних відносин }\end{array}$ \\
\hline Управлінський & $\begin{array}{l}\text { Управління культурою корпорації, тобто комплексом загальних традицій та } \\
\text { установок, принципів поведінки компанії стосовно основних їі підсистем } \\
\text { елементів, а також стосовно суспільства }\end{array}$ \\
\hline $\begin{array}{l}\text { Організаційно- } \\
\text { управлінський }\end{array}$ & $\begin{array}{l}\text { Система органів, посад, механізмів та функцій, що реалізують регулюючий } \\
\text { вплив на діяльність компанії }\end{array}$ \\
\hline Фінансовий & $\begin{array}{l}\text { Система органів та механізмів управлінського впливу, яка забезпечує } \\
\text { безперервний оптимальний рух фінансових потоків компанії }\end{array}$ \\
\hline $\begin{array}{l}\text { Фінансово- } \\
\text { майновий }\end{array}$ & $\begin{array}{l}\text { Обраний спосіб самоуправління, що забезпечує справедливий і рівноправний } \\
\text { розподіл результатів діяльності між усіма акціонерами, а також «фінансово } \\
\text { зацікавленими особами, насамперед кредиторами та інвесторами» }\end{array}$ \\
\hline
\end{tabular}


Така різноманітність підходів до розуміння сутності корпоративного управління зумовлює багатоформатність оцінювання його ефективності. Зазначимо, що ефективність корпоративного управління доцільно розглядати у трьох площинах:

1) юридично-правове забезпечення прав власників компанії, їх інтересів і повноважень щодо формування й управління власністю;

2) економіко-правова та ментальна складова формування механізму корпоративного управління;

3) забезпечення дієвості розробленої системи корпоративного управління та підвищення пї ефективності.

Отже, корпоративне управління - це сучасний вид управлінської діяльності акціонерного товариства, який характеризується наявністю корпоративної стратегії, корпоративного стилю роботи менеджерів усіх рівнів, корпоративної культури, фінансової та інформаційної відкритості, системи захисту прав акціонерів і власників інших цінних паперів підприємства-емітента.

До основних завдань корпоративного управління можна віднести:

- створення і забезпечення діяльності ефективного механізму аналізу, поточного й стратегічного управління, прийняття управлінських рішень та контроль за діяльністю товариства;

- забезпечення однакового і справедливого ставлення до всіх акціонерів;

- балансування інтересів акціонерів, менеджерів, працівників, клієнтів, партнерів і постачальників акціонерного товариства, тобто зацікавлених осіб, держави та суспільства [10].

Враховувати інтереси різних груп акціонерів дозволяє використання, запровадження і законодавче закріплення принципів корпоративного управління. Принципи корпоративного управління - це документ, що визначає правила, за якими вибудовуються стосунки на фінансових ринках у всьому світі й дотримання яких є однією 3 необхідних умов залучення інвестицій. Організація з питань економічного співробітництва та розвитку (ОЕСР) розробила перелік загальних принципів корпоративного управління, що можуть бути використані в законодавстві країнами 3 перехідною економікою. Ці принципи, що не $є$ обов'язковими для застосування навіть для країн-членів ОЕСР, являють собою спробу міжнародної спільноти створити загальноприйняті основи корпоративного управління. ОЕСР детально визначає п'ять принципів сучасного корпоративного управління (додаток А).

Система корпоративного управління - це організаційна модель, за допомогою якої компанія представляє і захищає інтереси своїх інвесторів. Тип застосування моделі залежить від структури компанії, що існує в межах ринкової економіки, і відображає сам факт поділу функцій управління та володіння корпорацією [11]. 
У розвинутих країнах світу існують різні моделі корпоративного управління. Модель корпоративного управління - це відображення найбільш суттєвих характеристик, властивостей та закономірностей функціонування корпоративного управління як об'єкта соціальноекономічної реальності, що створюється дослідником з метою отримання нових знань про систему корпоративного управління відповідно до мети дослідження [12]. Спеціалісти виділяють три моделі корпоративного управління: англо-американську, японську та німецьку.

Англо-американська модель (застосовується в корпораціях Великої Британії, США, Австралії, Нової Зеландії, Канади і деяких інших країн), характеризується наявністю індивідуальних та інституційних інвесторів і кількістю незалежних (яка постійно зростає), тобто не пов'язаних 3 корпорацією акціонерів (їх називають «зовнішніми» або «аутсайдерами»), а також чітко розробленою законодавчою базою, яка визначає права й обов'язки трьох ключових учасників - ради директорів, менеджерів і акціонерів [11].

Японська модель грунтується на тісному зв'язку з ключовим банком та фінансово-промисловою мережею (кейрецу). Банк надає своїм корпоративним клієнтам кредити і послуги з випуску цінних паперів, ведення розрахункових рахунків, консалтингові послуги. Цей банк найчастіше і $є$ основним внутрішнім акціонером компанії. Незалежні акціонери фактично не спроможні впливати на політику фірми, тому їхня кількість доволі незначна [11].

Німецька модель заснована на банківській системі (банки виступають кредиторами, голосуючими агентами, депозитаріями), акціонерах та працівниках [12]. Німецька модель має три унікальні особливості, що відрізняють їі від інших моделей: двопалатне правління, що складається з виконавчої і наглядової (спостережної) рад; узаконені обмеження прав акціонерів щодо голосування, тобто статут підприємства обмежує кількість голосів, які акціонер має на зборах, що може не збігатися з кількістю акцій, власником яких він $є$ [12].

Поліпшення корпоративного управління $є$ пріоритетним питанням для України, яка стала на шлях ринкової економіки. Недостатня увага до проблем корпоративного управління може призвести до ослаблення конкурентних позицій корпорацій. Особливого розгляду потребують питання формування корпоративної власності й механізму управління економічною безпекою як важливі умови успішної та ефективної діяльності корпоративних організацій.

Сьогодні система корпоративного управління в Україні проходить етап розвитку і становлення, що характеризується наявністю загальних рис як з англо-американською (основну роль відіграють інституційні інвестори й акціонери), так і з німецькою (система управління компанією складається з виконавчої й наглядової (спостережної) рад) та японською 
(деякі ринки мають ознаки існування ключового банку й фінансовопромислової мережі, акціонери-інсайдери заінтересовані в довгостроковому контролі над товариством більше, ніж в отриманні швидкого прибутку) моделями.

Серед домінуючих чинників, що сприяють формуванню інституту корпоративного управління в Україні, слід виділити інституційні та інтеграційні тенденції ринкових перетворень, активне залучення зовнішнього інвестування, а також боротьбу з ризиками недружнього поглинання.

Сьогодні корпоративний сектор вітчизняної економіки включає великі торговельні, логістичні, промислові компанії, промисловофінансові групи, холдингові та транснаціональні компанії, які мають визначальну роль у забезпеченні економічного зростання країни. Саме вони стають активними гравцями фінансових ринків, ведуть пошук зовнішніх джерел фінансування через механізм виходу на IPO.

Суттєвим поштовхом до впровадження в українських компаніях стандартів управління корпоративним бізнесом може стати глобальна фінансова криза. Як правило, складні економічні умови можуть не тільки перешкоджати успішному розвитку компаній, але й створити передумови для пошуку шляхів удосконалення або кардинальної зміни принципів державного управління та практики управління реальним бізнесом. Однією 3 причин світового економічного спаду аналітики визнають необгрунтовані фінансові рішення інвесторів, які призвели до значних втрат національного і приватного капіталу. Більшість експертів вважають, що корпоративне управління має стати дієвим механізмом забезпечення реалізації інтересів власників та інвесторів, упровадження нової управлінської логіки, яка базується на підходах пріоритетності добробуту власників компанії.

Корпоративне управління є важливим елементом ефективної ринкової економіки. Акціонери й інші зацікавлені особи повинні мати доступ до відповідної інформації та можливість здійснювати контроль і вплив стосовно керівництва 3 метою забезпечення використання активів компанії в інтересах усіх цих осіб. Контроль здійснюється за допомогою як внутрішніх процедур управління, так і зовнішніх правових регулюючих механізмів. Можливість здійснення такого контролю важлива як в економічно розвинених країнах, так і в країнах з економікою, що розвивається.

Для інвесторів і кредиторів повинні бути зрозумілі та прийнятні ті форми, в яких акціонери реалізують свою здатність здійснювати контроль за діяльністю керівництва і брати участь у найважливіших рішеннях.

Сумлінна практика корпоративного управління служить заставою того, що наступні компанії враховують інтереси широкого кола зацікавлених осіб і що їхнє керівництво підзвітне ії акціонерам. Це, у 
свою чергу, допомагає підтримувати довіру з боку інвесторів як іноземних, так і вітчизняних та залучати довгострокові кредити [13].

Використовуючи відповідну методологію оцінки корпоративного управління, слід аналізувати систему взаємодії між керівництвом компанії, іiі наглядовою радою, акціонерами й іншими зацікавленими особами, а також проводити всебічну оцінку стандартів управління за чотирма самостійними компонентами, а саме [14]:

- структура власності та вплив з боку власників;

- відносини із зацікавленими особами;

- фінансова прозорість і розкриття інформації;

- структура і методи роботи органів управління.

Складання рейтингу корпоративного управління регламентується Методичними рекомендаціями щодо створення та діяльності незалежних інформаційних і рейтингових агентств, що спеціалізуються на наданні інформаційних послуг на фондовому ринку України, які, в свою чергу, розроблені на основі Концепції створення системи рейтингової оцінки регіонів, галузей національної економіки, суб'єктів господарювання [15].

Рейтинг корпоративного управління та здійснюваний 3 цією метою аналіз дозволяють такій компанії позиціонуватися стосовно інших емітентів цінних паперів у конкурентному ринковому середовищі. Рейтинг корпоративного управління передбачає проведення аналізу ефективності взаємодії між керівництвом, наглядовою радою й акціонерами компанії та іншими особами, що мають у ній фінансовий інтерес. Головним об'єктом аналізу є внутрішня структура і методи корпоративного управління [16-23]. Основна увага приділяється тому, наскільки виконуються мінімальні вимоги місцевого законодавства та регулюючих принципів і може включати у себе аналіз корпоративного управління у країні (аналіз правової, регулюючої й інформаційної інфраструктури).

Рейтинг корпоративного управління компанії представляє собою поточний висновок щодо рівня відповідності практики корпоративного управління цієї компанії кодексам і принципам та кращій практиці у цій сфері [13].

Окрім цього, балами за шкалою від вищого до нижчого може оцінюватися кожний з чотирьох окремих компонентів. Ідеться про такі компоненти і субкомпоненти:

1. Структура корпоративного капіталу:

- прозорість структури;

- концентрація капіталу і вплив з боку власників.

2. Відносини із зацікавленими особами:

- регулярність проведення зборів акціонерів, можливість в них участі в них й одержання інформації про їх проведення;

- процедури голосування і ведення зборів акціонерів; 
- права власності (реєстрація і передача, рівність прав власності).

3. Фінансова прозорість і розкриття інформації:

- стандарти розкриття інформації;

- своєчасність і доступність інформації, що розкривається;

- незалежність аудитора.

4. Структура і методи роботи органів управління компанії:

- структура і склад наглядової ради;

- роль і ефективність ради директорів;

- незалежність зовнішніх директорів;

- політика у сфері винагород, оцінки результатів роботи осіб органів управління компанії.

В умовах економічної невизначеності існуючі методики виглядають недосконалими, оскільки не враховують одночасно якісні та кількісні показники, що знижує загальний ефект від такого оцінювання. Саме тому Методика складання рейтингу корпоративного управління, яка пропонується [13], базується не лише на оцінці якісних показників управління акціонерним товариством, а й на кількісних показниках його діяльності (рис. 1).

\section{ЯКІСНІ ПОКАЗНИКИ}

- порядок скликання та проведення Загальних зборів акціонерів;

- порядок емісії акцій товариства;

- робота Спостережної ради товариства;

- організація роботи виконавчого органу товариства;

- розкриття інформації та ії прозорість;

- контроль за фінансово-господарською діяльністю товариства.

\section{КІЛЬКІСНІ ПОКАЗНИКИ}

- рентабельність капіталу;

- рентабельність власного капіталу;

- період окупності власного капіталу;

- коефіцієнт фінансової незалежності;

- коефіцієнт фінансової стабільності;

- прибуток на одну акцію;

- дивіденд на акцію

- дивідендний вихід.

\section{Рис. 1. Якісні та кількісні показники оцінки стану корпоративного управління акціонерних товариств}

Джерело: розроблено автором самостійно.

Рейтинг складається лише на основі публічних даних, розкритих акціонерним товариством на сайтах інформаційних агентств, уповноважених Державною комісією з цінних паперів та фондового 
ринку і на сайті самого товариства. На підставі розробленої автором анкети (додаток Б), проводиться систематизація інформації для визначення та оцінки якісних показників. Порядок скликання й проведення загальних зборів акціонерів оцінюють за такими ознаками (табл. 2).

Таблиця 2

\section{Порядок скликання та проведення загальних зборів акціонерів}

\begin{tabular}{|l|c|}
\hline \multicolumn{1}{|c|}{ Показник } & Бали \\
\hline $\begin{array}{l}\text { Загальні збори акціонерів проводятьяя щороку, акціонери мають доступ до } \\
\text { документів, пов'язаних 3 порядком денним, мають право вносити пропозиції } \\
\text { щодо порядку денного, беруть участь в обговоренні та голосуванні, а також } \\
\text { одержують повну і достовірну інформацію про фінансово-господарський } \\
\text { стан Товариства та результати його діяльності }\end{array}$ & 5 балів \\
\hline $\begin{array}{l}\text { Загальні збори акціонерів проводяться щороку, акціонери мають доступ до } \\
\text { документів, пов'язаних з порядком денним та мають право вносити пропозиції } \\
\text { щодо порядку денного, беруть участь в обговоренні й голосуванні з питань } \\
\text { порядку денного, використовуючи бюлетені затвердженої форми }\end{array}$ & 4 бали \\
\hline $\begin{array}{l}\text { Загальні збори акціонерів проводятья щороку, акціонери мають право } \\
\text { доступу до документів, пов'язаних з порядком денним та вносити пропозиції } \\
\text { щодо доповнення порядку денного окремими питаннями не пізніше 30 днів } \\
\text { до скликання загальних зборів }\end{array}$ & 3 бали \\
\hline $\begin{array}{l}\text { Загальні збори акціонерів проводятья щороку, Товариство забезпечує } \\
\text { акціонерам можливість у будь-який час з моменту повідомлення про скликання } \\
\text { загальних зборів до дня їх проведення ознайомитися з документами, пов’язаними } \\
\text { з порядком денним }\end{array}$ & 2 бали \\
\hline $\begin{array}{l}\text { Загальні збори акціонерів проводяться щороку не пізніше 4 місяців після } \\
\text { закінчення фінансового року, акціонери повідомляютьяя про це не пізніше } \\
\text { як за 45 днів до їх проведення }\end{array}$ & 1 бал \\
\hline
\end{tabular}

Джерело: розроблено автором самостійно.

Порядок емісії акцій товариства оцінюють за такими ознаками (табл. 3).

Табличя 3

Порядок емісії акцій товариства

\begin{tabular}{|l|c|}
\hline \multicolumn{1}{|c|}{ Показник } & Бали \\
\hline $\begin{array}{l}\text { Товариство здійснювало емісію іменних акцій та акцій на пред’яника, звичайні } \\
\text { й привілейовані в бездокументарній формі, реєстр ведеться у депозитарії }\end{array}$ & 5 балів \\
\hline $\begin{array}{l}\text { Товариство здійснювало додаткові емісії звичайних іменних акцій у } \\
\text { бездокументарній формі, реєстр ведеться у депозитарії }\end{array}$ & 4 бали \\
\hline $\begin{array}{l}\text { Товариство здійснювало додаткові емісії звичайних іменних акцій у у } \\
\text { документарній формі, реєстр ведеться незалежним реєстратором }\end{array}$ & 3 бали \\
\hline $\begin{array}{l}\text { Товариство здійснювало емісію звичайних іменних акцій у документарній } \\
\text { формі лише при створенні, реєстр ведеться незалежним реєстратором }\end{array}$ & 2 бали \\
\hline $\begin{array}{l}\text { Товариство здійснювало емісію звичайних іменних акцій у документарній } \\
\text { формі лише при створенні, реєстр ведеться на підприємстві }\end{array}$ & 1 бал \\
\hline
\end{tabular}

Джерело: розроблено автором самостійно.

Робота спостережної ради товариства оцінюється за такими ознаками (табл. 4). 


\section{Робота спостережної ради товариства}

\begin{tabular}{|c|c|}
\hline Показник & Бали \\
\hline $\begin{array}{l}\text { Спостережна рада здійснює контроль за діяльністю виконавчого органу, } \\
\text { захист прав усіх акціонерів, звітує перед Загальними зборами акціонерів, має } \\
\text { у своєму складі незалежних членів, визначає основні цілі діяльності } \\
\text { Товариства, ухвалює стратегію для їх досягнення, щорічно проводить оцінку } \\
\text { своєї діяльності, в тому числі й за допомогою рейтингу. В своїй } \\
\text { організаційній структурі має посаду корпоративного секретаря }\end{array}$ & 5 балів \\
\hline $\begin{array}{l}\text { Спостережна рада здійснює контроль за діяльністю виконавчого органу, } \\
\text { захист прав усіх акціонерів, звітує перед Загальними зборами акціонерів, має } \\
\text { у своєму складі незалежних членів, визначає основні цілі діяльності } \\
\text { Товариства, ухвалює стратегію для їх досягнення }\end{array}$ & 4 бали \\
\hline $\begin{array}{l}\text { Спостережна рада здійснює контроль за діяльністю виконавчого органу, } \\
\text { захист прав усіх акціонерів, звітує перед Загальними зборами акціонерів, ії } \\
\text { члени володіють необхідними знаннями та досвідом. До іï складу входять } \\
\text { незалежні члени }\end{array}$ & 3 бали \\
\hline $\begin{array}{l}\text { Спостережна рада здійснює контроль за діяльністю виконавчого органу, } \\
\text { захист прав усіх акціонерів, звітує перед Загальними зборами акціонерів, ії } \\
\text { члени володіють знаннями, кваліфікацією та досвідом, необхідними для } \\
\text { виконання своїх обов'язків }\end{array}$ & 2 бали \\
\hline $\begin{array}{l}\text { Спостережна рада здійснює контроль за діяльністю виконавчого органу на } \\
\text { громадських засадах, її члени не мають достатньої кваліфікації та досвіду } \\
\text { роботи у цій сфері }\end{array}$ & 1 бал \\
\hline
\end{tabular}

Джерело: розроблено автором самостійно.

\section{Організація роботи виконавчого органу товариства оцінюється} за такими ознаками (табл. 5).

Таблиия 5

Організація роботи виконавчого органу товариства

\begin{tabular}{|l|c|}
\hline \multicolumn{1}{|c|}{ Показник } & Бали \\
\hline $\begin{array}{l}\text { Виконавчий орган здійснює поточне та перспективне управління Товариством, } \\
\text { подає Спостережній раді звіт про виконання оперативних і перспективних } \\
\text { планів та про фінансово-господарський стан діяльності Товариства }\end{array}$ & 5 балів \\
\hline $\begin{array}{l}\text { Виконавчий орган здійснює поточне та перспективне управління Товариством, } \\
\text { не рідше 1 разу на три місяці подають Спостережній раді звіт про виконання } \\
\text { оперативних планів Товариства }\end{array}$ & 4 бали \\
\hline $\begin{array}{l}\text { Виконавчий орган здійснює поточне та перспективне управління Товариством } \\
\text { відповідно до законодавства }\end{array}$ & 3 бали \\
\hline $\begin{array}{l}\text { Виконавчий орган розробляє та узгоджує із Спостережною радою проєкти } \\
\text { річного бюджету та стратегії Товариства }\end{array}$ & 2 бали \\
\hline Виконавчий орган здійснює керівництво поточною діяльністю Товариства & 1 бал \\
\hline
\end{tabular}

Джерело: розроблено автором самостійно.

Розкриття інформації та іiі прозорість оцінюють за такими ознаками (табл. 6).

Контроль за фінансово-господарською діяльністю товариства оцінюють за такими ознаками (табл. 7). 
Таблиия 6

Розкриття інформації та її прозорість

\begin{tabular}{|l|c|}
\hline \multicolumn{1}{|c|}{ Показник } & Бали \\
\hline $\begin{array}{l}\text { Товариство регулярно розкриває не лише річну, а й квартальну звітність у } \\
\text { офіційних виданнях та на Інтернет-сайті, а також розповсюджує річний звіт } \\
\text { разом з аудиторським висновком серед акціонерів, клієнтів, партнерів й } \\
\text { інвесторів. Про всі зміни у фінансово-господарській діяльності, які можуть } \\
\text { вплинути на вартість цінних паперів або доходу по них, Товариство } \\
\text { повідомляє не пізніше } 2 \text { днів } 3 \text { дати виникнення. Товариство регулярно } \\
\text { звертається до рейтингових агентств }\end{array}$ & \\
\hline $\begin{array}{l}\text { Товариство регулярно розкриває не лише річну, а й квартальну звітність у } \\
\text { офіційних виданнях та на Інтернет-сайті, а також розповсюджує річний звіт } \\
\text { разом з аудиторським висновком серед акціонерів, клієнтів, партнерів й інвесторів }\end{array}$ & 4 бали \\
\hline $\begin{array}{l}\text { Товариство регулярно розкриває не лише річну, а й квартальну звітність у } \\
\text { офіційних виданнях та на Інтернет-сайті }\end{array}$ & 3 бали \\
\hline $\begin{array}{l}\text { Товариство регулярно здає річний звіт, форма якого передбачена ДКЦПФР } \\
\text { та публікує його в одному з офіційних видань, а також розміщує електронний } \\
\text { варіант звіту на Інтернет-сайті }\end{array}$ & 2 бали \\
\hline $\begin{array}{l}\text { Товариство регулярно здає річний звіт, форма якого передбачена ДКЦПФР } \\
\text { та публікує його в одному з офіційних видань }\end{array}$ & 1 бал \\
\hline
\end{tabular}

Джерело: розроблено автором самостійно.

Таблиця 7

Контроль за фінансово-господарською діяльністю товариства

\begin{tabular}{|l|c|}
\hline \multicolumn{1}{|c|}{ Показник } & Бали \\
\hline $\begin{array}{l}\text { 3 метою захисту прав та інтересів акціонерів Товариство звертається до } \\
\text { незалежної аудиторської фірми, яка не змінюється. Досить ефективно } \\
\text { працює ревізійна комісія Товариства та його Спостережна рада. Товариством } \\
\text { створено відділ Внутрішнього контролю (аудиту) }\end{array}$ & балів \\
\hline $\begin{array}{l}3 \text { метою захисту прав та інтересів акціонерів Товариство звертається до } \\
\text { незалежної аудиторської фірми, яка не змінюєтья. Досить ефективно } \\
\text { працюють ревізійна комісія Товариства і його Спостережна рада }\end{array}$ & 4 бали \\
\hline $\begin{array}{l}\text { н метою захисту прав та інтересів акціонерів Товариство звертається до } \\
\text { незалежної аудиторської фірми, яка не змінюється останні 3-5 років. Досить } \\
\text { ефективно працює ревізійна комісія Товариства }\end{array}$ & 3 бали \\
\hline $\begin{array}{l}3 \text { метою захисту прав та інтересів акціонерів Товариство звертається до } \\
\text { незалежних аудиторських фірм, які не змінюються останні 3 роки }\end{array}$ & 2 бали \\
\hline $\begin{array}{l}3 \text { метою захисту прав та інтересів акціонерів Товариство звертається до } \\
\text { незалежних аудиторських фірм, які постійно змінюються }\end{array}$ & 1 бал \\
\hline
\end{tabular}

Джерело: розроблено автором самостійно.

Рентабельність капіталу розраховується за такою формулою $\left(X_{7}\right)$ [24]:

$$
X_{7}=\frac{\text { ЧП }}{A}=\frac{\text { ф. } 2 \text { ряд } .220}{\text { ф.1 ряд } .280}
$$

де ЧП - чистий прибуток товариства, $A$ - загальна сума активів.

Рентабельність капіталу показує, скільки гривень чистого прибутку припадає на 1 грн інвестованих в активи коштів. Збільшення 
цього показника характеризує позитивні зміни у діяльності товариства. Рентабельність капіталу доцільно оцінити так (табл. 8).

Таблиия 8

\section{Рентабельність капіталу}

\begin{tabular}{|l|c|}
\hline \multicolumn{1}{|c|}{ Показник } & Бали \\
\hline перевищус 0,1 & 5 балів \\
\hline у межах від 0,05 до 0,1 & 4 бали \\
\hline у межах від 0,0 до 0,05 & 3 бали \\
\hline у межах від -0,1 до 0,0 & 2 бали \\
\hline менше -0,1 & 1 бал \\
\hline
\end{tabular}

Рентабельність власного капіталу розраховується за такою формулою $\left(X_{8}\right)[25]$ :

$$
X_{8}=\frac{\text { ЧП }}{B K}=\frac{\phi .2 \text { ряд } .220}{\text { ф.1 ряд } .380}
$$

де ЧП - чистий прибуток, $B K$ - загальна сума власного капіталу товариства.

Рентабельність власного капіталу показує, скільки гривень чистого прибутку припадає на 1 грн інвестованих у власний капітал товариства коштів.

Рентабельність власного капіталу доцільно оцінити так (табл. 9).

Рентабельність власного капіталу
\begin{tabular}{|l|c|}
\hline \multicolumn{1}{|c|}{ Показник } & Бали \\
\hline перевищує 0,1 & 5 балів \\
\hline у межах від 0,05 до 0,1 & 4 бали \\
\hline у межах від 0,0 до 0,05 & 3 бали \\
\hline у межах від -0,1 до 0,0 & 2 бали \\
\hline менше - 0,1 & 1 бал \\
\hline
\end{tabular}

Таблиия 9

Період окупності власного капіталу розраховується за такою формулою $\left(X_{9}\right)[27]$ :

$$
X_{9}=\frac{B K}{\text { ЧП }}=\frac{\text { ф.1 ряд } .380}{\text { ф. } 2 \text { ряд } .220}
$$

де ЧП - чистий прибуток підприємства, $B K$ - загальна сума власного капіталу.

Період окупності власного капіталу показує, скільки, за який період власний капітал буде компенсований чистим прибутком товариства. Чим меншим буде цей показник, тим краще.

Період окупності власного капіталу доцільно оцінити так (табл. 10). 


\section{Період окупності власного капіталу}

Таблиияя 10

\begin{tabular}{|l|c|}
\hline \multicolumn{1}{|c|}{ Показник } & Бали \\
\hline $\begin{array}{l}\text { менше за операційний цикл } \\
\text { (менше 1 року) }\end{array}$ & 5 балів \\
\hline у межах від 1,0 до 1,5 року & 4 бали \\
\hline у межах від 1,5 до 2,0 років & 3 бали \\
\hline у межах від 2,0 до 2,5 років & 2 бали \\
\hline Перевищує 3 роки & 1 бал \\
\hline
\end{tabular}

Коєфіцієнт фінансової стійкості (незалежності) розраховується за такою формулою $\left(X_{10}\right)[13]$ :

$$
X_{10}=\frac{B K}{M}=\frac{\text { ф.1 ряд } .380}{\text { ф.1 ряд } .640}
$$

де $B K$ - власний капітал, $M$ - загальна сума майна товариства.

Характеризує можливість підприємства виконати свої зовнішні зобов'язання за рахунок власних джерел та показує незалежність підприємства від позикових джерел фінансування. Критичне значення - 0,5. При зменшенні значення коєфіцієнта підприємство втрачає свою незалежність.

Коєфіцієнт фінансової стійкості (незалежності) доцільно оцінити так (табл. 11).

Таблиияя 11

\section{Оцінка косфіцієнта фінансової стійкості (незалежності)}

\begin{tabular}{|l|c|}
\hline \multicolumn{1}{|c|}{ Показник } & Бали \\
\hline перевищує 1,0 & 5 балів \\
\hline у межах від 0,75 до 1,0 & 4 бали \\
\hline у межах від 0,5 до 0,75 & 3 бали \\
\hline у межах від 0,2 до 0,5 & 2 бали \\
\hline менше 0,2 & 1 бал \\
\hline
\end{tabular}

Коєфіцієнт фінансової стабільності (коєфіцієнт фінансування) розраховується за такою формулою $\left(X_{11}\right)$ [27]:

$$
X_{11}=\frac{B K}{\text { ДЗ } П \text { П3 }}=\frac{\text { ф.1 ряд. } 380}{\text { ф.1 ряд. } 480+\text { ф. } 1 \text { ряд. } 620}
$$

де $B K$ - власний капітал підприємства, ДЗ - довгострокові зобов'язання підприємства, ПЗ - поточні зобов'язання підприємства.

Коєфіцієнт фінансової стабільності показує забезпеченість заборгованості власними коштами. Критичне значення - 0,5. При зменшенні коєфіцієнта підприємство втрачає свою фінансову стабільність. 
Коєфіцієнт фінансової стабільності доцільно оцінити так (табл. 12).

Косфіціснт фінансової стабільності

Таблиця 12

\begin{tabular}{|l|c|}
\hline \multicolumn{1}{|c|}{ Показник } & Бали \\
\hline перевищує 1,0 & 5 балів \\
\hline у межах від 0,75 до 1,0 року & 4 бали \\
\hline у межах від 0,5 до 0,75 року & 3 бали \\
\hline у межах від 0,25 до 0,5 року & 2 бали \\
\hline менше 0,25 & 1 бал \\
\hline
\end{tabular}

Прибуток на одну акцію розраховується за такою формулою $\left(X_{12}\right)[13]:$

$$
X_{7}=\frac{\text { ЧП }}{3 в А \kappa}=\frac{\phi .2 \text { ряд } .220}{\text { ф. } 2 \text { ряд. } 300}=\text { ф. } 2 \text { ряд. } 320
$$

де ЧП - чистий прибуток підприємства, ЗвАк - кількість випущених звичайних (простих) акцій товариства.

Прибуток на одну акцію показує, скільки гривень чистого прибутку припадає на одну звичайну акцію товариства. Зростання цього показника свідчить про покращення корпоративного управління діяльністю товариства.

Прибуток на одну акцію доцільно оцінити так (табл. 13).

Таблиия 13

Прибуток на одну акцію

\begin{tabular}{|l|c|}
\hline \multicolumn{1}{|c|}{ Показник } & Бали \\
\hline вище номінальної вартості акції більше, ніж у 2 рази & 5 балів \\
\hline вище номінальної вартості акції менше, ніж у 2 рази & 4 бали \\
\hline дорівнює номінальній вартості акцій & 3 бали \\
\hline нижче номінальної вартості акції менше, ніж у 2 рази & 2 бали \\
\hline нижче номінальної вартості акції більше, ніж у 2 рази & 1 бал \\
\hline
\end{tabular}

Дивіденд на акцію розраховується за такою формулою $\left(X_{13}\right)[13]$ :

$$
X_{13}=\frac{\text { Дза- Дпа }}{\text { ЗвАк }}=\text { ф. } 2 \text { ряд. } 340
$$

де Дза - сума дивідендів за звичайними акціями, Дп $а$ - сума дивідендів за привілейованими акціями, ЗвАк - кількість випущених звичайних акцій товариства.

Дивіденд на акцію показує, скільки гривень чистого прибутку після сплати дивідендів за привілейованими акціями припадає на одну звичайну акцію товариства.

Дивіденд на акцію доцільно оцінити так (табл. 14). 


Дивіденд на акцію
\begin{tabular}{|l|c|}
\hline \multicolumn{1}{|c|}{ Показник } & Бали \\
\hline вище номінальної вартості акції більше, ніж у 2 рази & 5 балів \\
\hline вище номінальної вартості акції менше, ніж у 2 рази & 4 бали \\
\hline дорівнює номінальній вартості акцій & 3 бали \\
\hline нижче номінальної вартості акції менше, ніж у 2 рази & 2 бали \\
\hline нижче номінальної вартості акції більше, ніж у 2 рази & 1 бал \\
\hline
\end{tabular}

Дивідендний вихід розраховується за такою формулою $\left(X_{14}\right)$ [13]:

$$
X_{14}=\frac{X_{13}}{X_{12}}=\frac{\text { ф. } 2 \text { ряд. } 340}{\text { ф. } 2 \text { ряд. } 320}
$$

де $X_{13}$ - дивіденд на акцію, $X_{12}$ - прибуток на акцію товариства.

Дивідендний вихід показує частку дивідендів за звичайними акціями до сплати у чистому прибутку товариства. Залежить від дивідендної політики товариства.

Дивідендний вихід доцільно оцінити так (табл. 15).

Табличя 15

Дивідендний вихід
\begin{tabular}{|l|c|}
\hline \multicolumn{1}{|c|}{ Показник } & Бали \\
\hline перевищує 1,0 & 5 балів \\
\hline у межах від 0,75 до 1,0 & 4 бали \\
\hline у межах від 0,5 до 0,75 & 3 бали \\
\hline у межах від 0,2 до 0,5 & 2 бали \\
\hline менше 0,2 & 1 бал \\
\hline
\end{tabular}

На основі проведених експертних опитувань (додаток В) попередньо оціненим показникам присвоюються відповідні вагові коєфіцієнти (табл. 16).

Зазначені вагові коєфіцієнти були визначені на основі опитування спеціалістів, що працюють наразі на підприємствах різних форм власності, а також у банківських установах, інвестиційних компаніях, державних структурах тощо. Сумарний бал оцінки рівня корпоративного управління акціонерного товариства визначається множенням кількості отриманих балів за кожним фактором на ваговий коєфіцієнт з подальшим сумуванням отриманих результатів:

$$
R_{\text {crop }}=F\left(X_{i}\right)=\sum_{i=1}^{n}\left[B_{i} \times K_{i}\right]
$$

де $R_{\text {crop }}$ - сумарний бал оцінки рівня корпоративного управління Товариства; $B_{i}$ - кількість балів за і-тим фактором $(i=1, \ldots, n) ; K_{i}-$ ваговий коєфіцієнт $i$-того фактору $(i=1, \ldots, n)$. 
Перелік вагових косфіціснтів

\begin{tabular}{|l|c|}
\hline \multicolumn{1}{|c|}{ Показник } & $\begin{array}{c}\text { Ваговий } \\
\text { коєфіцієнт }\end{array}$ \\
\hline порядок скликання та проведення Загальних зборів акціонерів & 0,10 \\
\hline порядок емісії акцій товариства & 0,08 \\
\hline робота Спостережної ради товариства & 0,10 \\
\hline організація роботи виконавчого органу товариства & 0,10 \\
\hline розкриття інформації та ії прозорість & 0,12 \\
\hline контроль за фінансово-господарською діяльністю товариства & 0,10 \\
\hline рентабельність капіталу & 0,02 \\
\hline рентабельність власного капіталу & 0,05 \\
\hline період окупності власного капіталу & 0,05 \\
\hline коєфіцієнт фінансової незалежності & 0,10 \\
\hline коєфіцієнт фінансової стабільності & 0,05 \\
\hline прибуток на одну акцію & 0,05 \\
\hline дивіденд на акцію & 0,05 \\
\hline дивідендний вихід & 0,03 \\
\hline Джерело: розробло авпоролсамостій.
\end{tabular}

Джерело: розроблено автором самостійно.

На основі сумарного балу оцінки рівня корпоративного управління акціонерні товариства ранжують за класами А, Б, В, Г та Д. Відповідні розрахунки рейтингу корпоративного управління Товариства здійснюються за допомогою розробленої нами прикладної програми на основі Excel 2000. Ранжування акціонерних товариств на класи здійснюється за допомогою табл. 17.

Таблиия 17

Критерії оцінки стану корпоративного управління акціонерного товариства

\begin{tabular}{|c|c|c|}
\hline Клас & Характеристика класу & $\begin{array}{c}\text { Сумарний } \\
\text { бал }\end{array}$ \\
\hline A & $\begin{array}{l}\text { Акціонерне товариство проводить ефективне корпоративне управління, } \\
\text { яке характеризується відкритістю інформації щодо основних напрямів } \\
\text { діяльності, взаємовідносин } 3 \text { акціонерами, Спостережною радою та } \\
\text { Ревізійною комісією. Аналіз коєфіцієнтів оцінки прибутковості та } \\
\text { ринкової активності Товариства свідчить про позитивні тенденції в } \\
\text { його діяльності. Товариство проводить послідовну дивідендну політику, } \\
\text { яка є відкритою для акціонерів }\end{array}$ & $\begin{array}{c}\text { Від } 4,2 \\
\text { до } 5,0\end{array}$ \\
\hline Б & $\begin{array}{l}\text { Акціонерне товариство проводить ефективне корпоративне управління, } \\
\text { яке характеризується відкритістю інформації щодо основних напрямів } \\
\text { діяльності, взаємовідносин з акціонерами, Спостережною радою та } \\
\text { Ревізійною комісією, проте є інформація про ймовірність неможливості } \\
\text { підтримки його на цьому рівні протягом тривалого часу. Товариства, } \\
\text { які віднесені до цього класу, потребують більшої уваги через потенційні } \\
\text { недоліки, що ставлять під загрозу ефективне корпоративне управління. } \\
\text { Аналіз коєфіцієнтів оцінки прибутковості та ринкової активності } \\
\text { Товариства може вказувати на негативні тенденції в його діяльності }\end{array}$ & $\begin{array}{c}\text { Від } 3,4 \\
\text { до } 4,2\end{array}$ \\
\hline
\end{tabular}


Продовження табл. 17

\begin{tabular}{|c|c|c|}
\hline B & $\begin{array}{l}\text { Акціонерне товариство проводить корпоративне управління, яке } \\
\text { характеризується недостатнім рівнем інформаційної відкритості } \\
\text { щодо основних напрямів діяльності, взаємовідносин } 3 \text { акціонерами, } \\
\text { Спостережною радою та Ревізійною комісією. Товариство проводить } \\
\text { відкриту підписку на випущені акції, що не мають високої ринкової } \\
\text { вартості та не надходять у вільний обіг на фондовому ринку. } \\
\text { Спостережна рада Товариства здійснює лише контроль за діяльністю } \\
\text { виконавчого органу й доповідає про це на Загальних зборах акціонерів. } \\
\text { Аналіз коєфіцієнтів оцінки прибутковості та ринкової активності } \\
\text { Товариства вказує на негативні тенденції в його діяльності. }\end{array}$ & $\begin{array}{c}\text { Від 2,6 } \\
\text { до } 3,4\end{array}$ \\
\hline$\Gamma$ & $\begin{array}{l}\text { Акціонерне товариство проводить корпоративне управління, яке } \\
\text { характеризується недостатнім рівнем інформаційної відкритості } \\
\text { щодо основних напрямів діяльності та взаємовідносин з акціонерами. } \\
\text { Акції товариства мають низьку ринкову вартість і не користуються } \\
\text { попитом на фондовому ринку. Спостережна рада Товариства здійснює } \\
\text { лише візуальний контроль за діяльністю виконавчого органу й } \\
\text { доповідає про це на Загальних зборах акціонерів, а для детальної } \\
\text { перевірки запрошуютья зовнішні аудиторську фірми. Аналіз діяльності } \\
\text { Товариства вказує на неприбутковість та низьку ринкову активність. }\end{array}$ & $\begin{array}{c}\text { Від } 1,8 \\
\text { до } 2,6\end{array}$ \\
\hline Д & $\begin{array}{l}\text { Акціонерне товариство проводить корпоративне управління, яке } \\
\text { характеризуєтья недостатнім рівнем професіоналізму та інформаційної } \\
\text { відкритості. Акції товариства мають низьку ринкову вартість і не } \\
\text { користуються попитом на фондовому ринку. Спостережна рада здійснює } \\
\text { контроль за діяльністю виконавчого органу на громадських засадах, } \\
\text { ї̈ члени не мають достатньої кваліфікації та досвіду роботи у цій сфері. } \\
\text { Аналіз діяльності Товариства вказує на неприбутковість і низьку ринкову } \\
\text { активність. Імовірність виконання зобов’язань Товариства перед } \\
\text { акціонерами є низькою. }\end{array}$ & Менше 1,8 \\
\hline
\end{tabular}

Джерело: розроблено автором самостійно.

Отримані результати, що характеризують стан корпоративного управління в акціонерному товаристві, автор пропонує використовувати при прогнозуванні стану економічної безпеки емісійної діяльності.

\section{Висновки:}

Отже, запропонований інструментарій сприятиме оцінюванню стану корпоративного управління за умов економічної невизначеності, що дозволить виокремити фактори, які впливають на діяльність акціонерних товариств, та удосконалити стратегію розвитку корпорацій.

\section{Jimepamypa:}

1932.

1. Berle A., Means G. The Modern Corporation and Private Property.

2. Свтушевський В. А. Корпоративне управління: підручник. Київ : Знання, 2006. 408 с.

3. Задихайло Д. В. Корпоративне управління : навч. посіб. для студ. вищ. навч. закл. Харків : Еспада, 2003. 688 с. 
4. Господарський кодекс України від 16.01.2003 p. №436-IV. Редакція від 16.08.2020, підстава - 815-IX. URL : https://zakon.rada.gov. ua/laws/show/436-15\#Text.

5. Про акціонерні товариства : Закон України №514-VI від 17.09.2008 p. Редакція від 16.08.2020, підстава - 738-IX. URL : https://zakon.rada.gov.ua/laws/show/514-17\#Text.

6. Момот Т. В. Вартісно-орієнтоване корпоративне управління: від теорії до практичного впровадження : монографія. Харків : ХНАМГ, 2006. $380 \mathrm{c}$.

7. Верба В. А. Становлення корпоративного управління як чинник попиту на консалтингові послуги в Україні. Механізм регулювання економіки. 2009. №1. С. 92-101.

8. Ліщинський М. П. Система корпоративного управління в умовах трансформаційного розвитку аграрного сектору економіки України. Науковий вісник Національного університету біоресурсів $i$ природокористування Украӥни. 2010. Вип. 154. Частина 2. URL : http://www.nbuv.gov.ua/portal/chem_biol/nvnau/2010_154_2/10lmp.pdf.

9. Корпоративне управління : підручник / Мостенська Т. Л., Новак В. О., Луцький М. Г., Симоненко Ю. Г. Київ : Каравелла; Піча Ю. В., 2008. $384 \mathrm{c}$.

10. Хабарова И. А. Корпоративное управление: вопросы интеграции, аффилированные лица, организационное проектирование, интеграционная динамика : учебное пособие. Москва : Издательский дом «Альпина», 2000.

11. Довгань Л. С., Пастухова В. В., Савчук Л. М. Управління корпораціями : монографія. Київ : ІВЦ Вид-во «Політехніка», 2004. 236 с.

12. Формування моделі корпоративного управління в трансформаційній економіці : навч. посіб. / Круш П. В., Кавтиш О. П., Гречко А. В., Чихачова Ю. С.; під заг. ред. к.е.н., проф. П. В. Круша. Київ : ЦУЛ, 2007. 264 с.

13. Мігус І. П. Ринок фінансових послуг: методичні рекомендації для складання рейтингів суб'єктів господарювання : навч. посібник. Київ : Європейський університет, 2005. 188 с.

14. Про схвалення Методичних рекомендацій Державної комісії 3 цінних паперів та фондового ринку щодо створення та розвитку незалежних інформаційних та рейтингових агентств, що спеціалізуються на наданні інформаційних послуг на фондовому ринку України : Рішення Державної комісії $з$ цінних паперів та фондового ринку №370 від 31.08.2004p. URL : http://search.ligazakon.ua/__doc2.nsf/link1/KML04477.html.

15. Про схвалення Концепції створення системи рейтингової оцінки регіонів, галузей національної економіки, суб'єктів господарювання : Розпорядження Кабінету Міністрів України №208-р від 1 квітня 2004 р. URL : https://zakon.rada.gov.ua/laws/show/208-2004-\%D1\%80\#Text. 
16. Рябота В. Корпоративний секретар : посібник. Київ : Міжнародна фінансова корпорація, 2005. 160 с.

17. Пособие по корпоративному управлению: в 6 т. Т. 1: Часть 1. Введение в корпоративное управление. Москва : Альпина Бизнес Букс, $2004.93 \mathrm{c}$.

18. Пособие по корпоративному управлению: в 6 т. Т. 2: Часть 2. Совет директоров и исполнительные органы общества. Москва : Альпина Бизнес Букс, 2004. 141 с.

19. Пособие по корпоративному управлению: в 6 т. Т. 3: Часть 3. Права акционеров. Москва : Альпина Бизнес Букс, 2004. 233 с.

20. Пособие по корпоративному управлению: в 6 т. Т. 4: Часть 4. Раскрытие информации и прозрачность. Москва : Альпина Бизнес Букс, 2004. $111 \mathrm{c}$.

21. Пособие по корпоративному управлению: в 6 т. Т. 5: Часть 5. Некоторые специальные вопросы. Москва : Альпина Бизнес Букс, 2004. 108 c.

22. Пособие по корпоративному управлению: в 6 т. Т. 6: Часть 6. Приложения. Типовые документы. Москва : Альпина Бизнес Букс, 2004. $365 \mathrm{c}$.

23. Балабаров С., Рябота В., Михайлюк О. Ефективна рада : посібник. Київ : Міжнародна фінансова корпорація, 2007. 112 с.

24. Про внесення змін до деяких законодавчих актів України щодо відповідальності за правопорушення на ринку цінних паперів України: Закон України №801-VI від 25 грудня 2008 р. Редакція від 19.11.2012, підстава - 4651-VI. URL : https://zakon.rada.gov.ua/laws/show/ 801-17\#Text.

25. Мартін Джон Д., Петті Вільям Дж. VBM - управління, що базується на вартості : Корпоративна відповідь революції акціонерів / пер. 3 англ.; за наук. ред. О. Б. Максимової, І. Ю. Шарапової. Дніпропетровськ : Баланс Бізнес Букс, 2006. 272 с. 


\section{ДОДАТОК А}

Таблиия A. 1

Сутність принципів корпоративного управління ОЕСР

\begin{tabular}{|c|c|}
\hline $\begin{array}{c}\text { Визначення } \\
\text { принцпу }\end{array}$ & Зміст принципу \\
\hline $\begin{array}{c}\text { Захист прав } \\
\text { акціонерів }\end{array}$ & $\begin{array}{l}\text { А) Основні права акціонерів: надійні методи реєстрації власності; } \\
\text { передача акцій; регулярне та своєчасне отримання інформації } \\
\text { про корпорацію; участь і голосування на Загальних зборах } \\
\text { акціонерів; участь у виборах Ради; отримання частки прибутку } \\
\text { корпорації. } \\
\text { Б) Акціонери мають право на участь у прийнятті рішень та } \\
\text { отриманні достатньої інформації стосовно питань, пов'язаних з } \\
\text { фундаментальними змінами в корпорації. } \\
\text { В) Акціонери повинні мати можливість ефективно брати участь } \\
\text { у Загальних зборах акціонерів та голосувати на зборах, а також } \\
\text { бути поінформованими про правила, включаючи порядок } \\
\text { голосування, що регламентують проведення Загальних зборів. } \\
\text { Г) Підлягають оприлюдненню (розкриттю) структра капіталу } \\
\text { та механізми, які дозволяють окремим акціонерам отримувати } \\
\text { контроль, що не зіставний з їхною часткою в акціонерній } \\
\text { власності. } \\
\text { Д) Ринки корпоративного контролю повинні мати можливість } \\
\text { функціонувати ефективно і прозоро. } \\
\text { Е) Акціонери, в тому числі інституційні інвестори, мають } \\
\text { враховувати, які витрати та вигоди несе використання ними } \\
\text { свого права голосу. }\end{array}$ \\
\hline $\begin{array}{c}\text { Рівне } \\
\text { ставлення до } \\
\text { всіх } \\
\text { акціонерів, } \\
\text { включаючи } \\
\text { іноземних та } \\
\text { мінорітарних }\end{array}$ & $\begin{array}{l}\text { А) Ставлення до всіх акціонерів, які є власниками акцій одного } \\
\text { виду, має бути однаковим. } \\
\text { Б) Необхідно заборонити будь-які операції у власних інтересах } \\
\text { та операції з використанням закритої інформації. } \\
\text { В) Члени Спостережної ради та Правління зобов'язані повідомити } \\
\text { про свою матеріальну зацікавленість в угодах або питаннях, що } \\
\text { стосуються корпорації. }\end{array}$ \\
\hline $\begin{array}{c}\text { Роль } \\
\text { зацікавлених } \\
\text { осіб в } \\
\text { управлінні } \\
\text { компанією }\end{array}$ & $\begin{array}{l}\text { А) Система корпоративного управління має забезпечувати } \\
\text { дотримання захищених законом прав зацікавлених осіб. } \\
\text { Б) Якщо їхні інтереси захищені законом, зацікавлені особи повинні } \\
\text { мати можливість використовувати ефективні методи захисту в } \\
\text { разі порушення їхіх прав. } \\
\text { В) Система корпоративного управління повинна дозволяти } \\
\text { участь зацікавлених осіб у заходах для підвищення ефективності } \\
\text { діяльності компанії. } \\
\text { Г) Якщо зацікавлені особи беруть участь у процесі корпоративного } \\
\text { управління, вони повинні мати доступ до необхідної інформації. }\end{array}$ \\
\hline
\end{tabular}


Продовження табл. А. 1

\begin{tabular}{|c|c|}
\hline $\begin{array}{c}\text { Розкриття } \\
\text { інформації та } \\
\text { прозорість }\end{array}$ & $\begin{array}{l}\text { А) Інформація, що підлягає розкриттю, повинна включати: } \\
\text { результати фінансової та операційної (господарської) діяльності } \\
\text { компанії; завдання компанії; володіння значними пакетами } \\
\text { акцій і права голосу; список членів Ради та Правління, а також } \\
\text { розмір винагороди, яку кожен з них отримує; значущі фактори } \\
\text { ризику, що можна спрогнозувати; важливі питання, які пов'язані } \\
3 \text { працівниками та іншими зацікавленими особами; структура й } \\
\text { політика управління компанією. } \\
\text { Б) Інформація повинна готуватися, перевірятися та розкриватися } \\
\text { відповідно до високих стандартів якості розкриття фінансової й } \\
\text { нефінансової інформації та аудиту. } \\
\text { В) } 3 \text { метою забезпечення належної підготовки та надання } \\
\text { фінансової звітності слід щороку проводити аудиторські перевірки } \\
\text { з використанням незалежного аудитора, який дає зовнішню й } \\
\text { об'єктивну оцінку цієї звітності. } \\
\text { Г) Канали розповсюдження інформації повинні передбачати } \\
\text { рівноправний, своєчасний та не пов’язаний із надмірними витратами } \\
\text { доступ користувачів до необхідної інформації. }\end{array}$ \\
\hline $\begin{array}{c}\text { Обов'язки } \\
\text { Ради }\end{array}$ & $\begin{array}{l}\text { А) Члени Ради повинні діяти на основі всієї необхідної } \\
\text { інформації, сумлінно, з належною обачністю та обережністю, в } \\
\text { найкращих інтересах компанії і акціонерів. } \\
\text { Б) Якщо рішення Ради можуть по-різному впливати на різні } \\
\text { групи акціонерів, вона має однаково справедливо ставитися до всіх } \\
\text { акціонерів. } \\
\text { В) Рада повинна забезпечити дотримання відповідного законодавства } \\
\text { та враховувати інтереси зацікавлених осіб. } \\
\text { Г) Рада повинна виконувати певні ключові функції. } \\
\text { Д) Рада повинна мати можливість виносити об'єктивне, незалежне, } \\
\text { зокрема від Правління, судження у справах акціонерів. } \\
\text { Е) Щоб мати можливість виконувати свої обов'язки, члени Ради } \\
\text { повинні мати доступ до інформації, яка є точною, своєчасною і } \\
\text { стосується справи. }\end{array}$ \\
\hline
\end{tabular}




\section{ДОДАТОК Б}

AHKETA

для визначення вагових коєфіціснтів якісних та кількісних показників оцінки корпоративного управління акціонерного товариства

\begin{tabular}{|l|l|l|l|l|l|}
\hline \multicolumn{1}{|c|}{ Показники } & $\mathbf{5}$ & $\mathbf{4}$ & $\mathbf{3}$ & $\mathbf{2}$ & $\mathbf{1}$ \\
\hline $\begin{array}{l}\text { Порядок скликання та проведення } \\
\text { Загальних зборів акціонерів }\end{array}$ & & & & & \\
\hline Порядок емісії акцій товариства & & & & & \\
\hline Робота Спостережної ради товариства & & & & & \\
\hline $\begin{array}{l}\text { Організація роботи виконавчого } \\
\text { органу товариства }\end{array}$ & & & & & \\
\hline Розкриття інформації та ііі прозорість & & & & & \\
\hline $\begin{array}{l}\text { Контроль за фінансово-господарською } \\
\text { діяльністю товариства }\end{array}$ & & & & & \\
\hline Рентабельність капіталу & & & & & \\
\hline Рентабельність власного капіталу & & & & & \\
\hline Період окупності власного капіталу & & & & & \\
\hline $\begin{array}{l}\text { Коєфіцієнт фінансової стійкості } \\
\text { (незалежності) }\end{array}$ & & & & & \\
\hline $\begin{array}{l}\text { Коєфіцієнт фінансової стабільності } \\
\text { коєфіцієнт фінансування) }\end{array}$ & & & & & \\
\hline Прибуток на одну акцію & & & & & \\
\hline Дивіденд на акцію & & & & & \\
\hline Дивідендний вихід & & & & & \\
\hline
\end{tabular}




\section{ДОДАТОК В}

\section{AHKETA \\ для проведення якісної оцінки корпоративного управління при складанні рейтингу корпоративного управління}

1. Найменування юридичної особи

2. Ідентифікаційний код (СДРПОУ)

3. Місцезнаходження

4. Юридична адреса

5. E-mail або Інтернет-сайт

6. Дата проведення та орган державної ресстрації

7. Види діяльності за КВЕД

8. Система оподаткування (підкреслити) - загальна, фіксований сільськогосподарський податок, єдиний податок $(3 \%, 5 \%)$.

9. Розмір статутного капіталу

10. Номінальна вартість акцій

11. Кількість випущених акцій

12. Чисельність акціонерів та їх частка

- юридичні особи -

- фізичні особи -

13. Перелік акціонерів, частка яких у статутному капіталі перевищус $10 \%$

14. Ліцензії, отримані на здійснення певних видів діяльності:

15. Керівник (директор, Голова Правління) підприсмства:

П.I.Б.

Дата народження _ـ Код

Освіта

Досвід роботи за фахом

Стаж роботи на займаній посаді

16. Головний бухгалтер:

П.I.Б.

Дата народження

Код

Освіта

Досвід роботи за фахом

Стаж роботи на займаній посаді

17. Заступник керівника (директора, Голови Правління) з фінансових питань:

П.І.Б.

Дата народження

Код

Освіта

Досвід роботи за фахом

Стаж роботи на займаній посаді 
18. Голова Спостережної ради:

П.І.Б.

Дата народження _ К Код

Освіта

Досвід роботи за фахом

Стаж роботи на займаній посаді

19. Голова ревізійної комісії:

П.І.Б.

Дата народження _ـ Код

Освіта

Досвід роботи за фахом

Стаж роботи на займаній посаді

20. Наявність заресстрованої торговельної марки (так, ні )

21. Кількість років діяльності підприємства

22. Наявність внутрішнього контролю на підприємстві та його форма

23. Періодичність проведення обов'язкових аудиторських перевірок

24. Періодичність проведення тематичних аудиторських перевірок

25. Скільки років співпрацюєте з аудиторською фірмою. Якщо вона часто змінюється, то чому?

26. Результати проведення перевірок державних органів - адміністративні, фінансові, кримінальні санкції (необхідне підкреслити та розшифрувати).

27. Як часто в акціонерному товаристві скликаються Загальні збори акціонерів?

1) щороку, один раз на рік;

2) щороку, кожні дев'ять місяців;

3) щороку, кожні пів року.

28. Як часто в акціонерному товаристві скликаються позачергові Загальні збори акціонерів?

1) щороку, один раз на рік;

2) щороку, кожні дев'ять місяців;

3) щороку, кожні пів року;

4) жодного разу не скликалися.

29. Де проходять Загальні збори акціонерів?

1) на території самого акціонерного товариства;

2) за межами акціонерного товариства, але у місті, де воно зареєстроване;

3) в іншому місті.

30. Хто здійснює організацію та проведення Загальних зборів акціонерів?

1) виконавчий орган акціонерного товариства (Правління);

2) Спостережна рада акціонерного товариства;

3) незалежний реєстратор;

4) представники Державної комісії з цінних паперів та фондового ринку;

5) мандатна комісія, призначена Правлінням;

6) інше. 
31. Хто здійснює контроль за ресстрацією акціонерів та їх представників, які беруть участь у Загальних зборах?

1) виконавчий орган акціонерного товариства (Правління);

2) Спостережна рада акціонерного товариства;

3) незалежний реєстратор;

4) представники акціонерів;

5) представники Державної комісії з цінних паперів та фондового ринку;

6) інші особи;

7) контроль не здійснювався.

32. Яким чином проводиться голосування під час Загальних зборів акціонерів?

1) $з$ допомогою карток;

2) шляхом підняття рук;

3) $з$ допомогою мандатів;

4) 3 допомогою бюлетенів, затверджених Спостережною радою;

5) з допомогою бюлетенів, затверджених Загальними зборами акціонерів.

33. Хто веде протокол засідання Загальних зборів акціонерів?

1) секретар Загальних зборів акціонерного товариства;

2) представник Спостережної ради;

3) корпоративний секретар;

4) працівник відділу роботи з акціонерами.

34. Хто здійснюс підрахунок голосів під час проведення Загальних зборів акціонерів?

1) лічильна комісія, обрана Загальними зборами акціонерів;

2) лічильна комісія, затверджена Спостережною радою;

3) лічильна комісія, затверджена Правлінням акціонерного товариства.

35. Хто відповідає за зберігання протоколів Загальних зборів акціонерів?

1) корпоративний секретар;

2) секретар Загальних зборів акціонерного товариства;

3) представник Спостережної ради;

4) представник виконавчого органу акціонерного товариства;

5) відділ роботи з акціонерами.

36. Скільки осіб входить до складу Спостережної ради акціонерного товариства?

1) менше 4 осіб;

2) 4 особи;

3) 5 осіб;

4) більше 5 осіб.

37. Хто входить до складу Спостережної ради?

1) працівники акціонерного товариства;

2) акціонери;

3) незалежні експерти.

38. Яка кількість проведених засідань Спостережної ради на рік?

1) менше 3 засідань;

2) 3-4 засідання;

3) 4-6 засідань;

4) більше 6 засідань.

39. Скільки осіб входить до складу Ревізійної комісії акціонерного товариства?

1) менше 4 осіб;

2) 4 особи;

3) 5 осіб;

4) більше 5 осіб.

40. Хто входить до складу ревізійної комісії?

1) працівники акціонерного товариства;

2) акціонери;

3) незалежні експерти. 
41. Яка кількість проведених засідань Ревізійної комісії на рік?

1) менше 3 засідань;

2) 3 - 4 засідання;

3) 4 - 6 засідань;

4) більше 6 засідань.

42. Хто розробляє стратегію діяльності акціонерного товариства?

1) загальні збори акціонерів;

2) Спостережна рада;

3) Правління.

43. До чиєї компетенції належать питання обрання та відкликання членів виконавчого органу (Правління)?

1) Спостережній раді;

2) Загальним зборам акціонерів.

44. Чи передбачені Статутом обмеження для представників виконавчого органу щодо укладання угод від імені акціонерного товариства, за яких рішення про укладання таких угод приймається виключно Загальними зборами акціонерів?

1) не передбачені;

2) передбачені, залежно від суми угоди у відсотках від розміру статутного капіталу акціонерного товариства;

3) передбачені, залежно від суми угоди у відсотках від розміру балансової вартості активів акціонерного товариства;

4) передбачені інші обмеження.

45. Чи мають посадові особи виконавчого органу акціонерного товариства особисту зацікавленість у здійсненні товариством своєї діяльності (конфлікт інтересів)?

1) найбільшим акціонером $є$ голова Правління;

2) найбільшим акціонером є голова Спостережної ради;

3) найбільшими акціонерами є члени Правління;

4) найбільшими акціонерами є незацікавлені особи.

46. Яким чином урегульовані відносини між товариством та членами Спостережної ради?

1) шляхом укладання цивільно-правових договорів, у яких передбачена оплата їх праці та інші взаємовідносини;

2) на громадських засадах;

3) іншим способом

47. Якими документами передбачені основні права й обов'язки Голови та членів Правління акціонерного товариства?

1) Цивільним кодексом України;

2) Статутом акціонерного товариства;

3) Установчим договором акціонерного товариства;

4) Положенням про роботу Правління акціонерного товариства;

5) іншими документами.

48. Якими документами передбачені основні права й обов'язки Голови та членів Спостережної ради акціонерного товариства?

1) Цивільним кодексом України;

2) Статутом акціонерного товариства;

3) Установчим договором акціонерного товариства;

4) Положенням про роботу Спостережної ради акціонерного товариства;

5) іншими документами.

49. Яким чином здійснюється розповсюдження інформації про діяльність акціонерного товариства?

1) Товариство регулярно здає річний звіт встановленої форми до ДКЦПФР;

2) Товариство регулярно публікує річний звіт встановленої форми в одному з офіційних видань ДКЦПФР;

3) Товариство оприлюднює свою річну звітність на Інтернет-сайті; 
4) Товариство розповсюджує річний звіт разом з аудиторським висновком серед акціонерів, клієнтів, партнерів та інвесторів;

5) про всі зміни у фінансово-господарській діяльності, які можуть вплинути на вартість цінних паперів або доходу по них, Товариство повідомляє не пізніше 2 днів 3 дати виникнення;

6) Товариство регулярно звертається до рейтингових агентств для оцінки його фінансового стану та складання кредитного рейтингу.

50. Яким чином повідомляються акціонери про проведення Загальних зборів та про їх порядок денний?

1) оголошення про скликання Загальних зборів акціонерів друкується у спеціалізованій та місцевій пресі не пізніше як за 45 днів до їх проведення;

2) кожному з акціонерів надсилається оголошення про проведення Загальних зборів акціонерного товариства та їх порядок денний;

3) акціонерам надається можливість ознайомитися 3 документами, пов'язаними 3 порядком денним;

4) акціонери мають право вносити пропозиції щодо доповнення порядку денного окремими питаннями не пізніше 30 днів до скликання Загальних зборів;

5) акціонери мають можливість одержати повну та достовірну інформацію про фінансово-господарський стан Товариства і результати його діяльності.

51. Які акції випускає акціонерне товариство?

1) Товариство здійснювало емісію звичайних іменних акцій у документарній формі;

2) Товариство здійснювало емісії звичайних іменних акцій у бездокументарній формі;

3) Товариство здійснювало емісію звичайних акцій на пред'явника у документарній формі;

4) Товариство здійснювало емісію звичайних акцій на пред’явника у бездокументарній формі;

5) Товариство здійснювало емісію привілейованих іменних акцій у документарній формі;

6) Товариство здійснювало емісії привілейованих іменних акцій у бездокументарній формі;

7) Товариство здійснювало емісію привілейованих акцій на пред’явника у документарній формі;

8) Товариство здійснювало емісію привілейованих акцій на пред’явника у бездокументарній формі.

52. Хто веде реєстр власників акцій Товариства?

1) реєстр ведеться на підприємстві;

2) реєстр ведеться незалежним реєстратором;

3) реєстр ведеться у депозитарії.

53. Як часто здійснюсться випуск акцій Товариством?

1) Товариство здійснювало емісію акцій лише при створенні;

2) Товариство здійснювало додаткову емісію акцій 1 раз;

3) Товариство здійснює додаткову емісію акцій більше 1 разу.

54. Яким чином акціонерне товариство поповнюс свої оборотні активи?

1) за рахунок прибутку;

2) за рахунок невиплачених дивідендів;

3) за рахунок банківських кредитів;

4) за рахунок додаткових емісій акцій;

5) за рахунок випуску облігацій;

6) за рахунок інвестицій інших підприємств;

7) іншим способом. 


\title{
КОМПАРАТИВНИЙ АНАЛІЗ МЕТОДІВ ПРОТИДІЇ ЛЕГАЛІЗАЦІЇ (ВІДМИВАННЮ) ДОХОДІВ, ОДЕРЖАНИХ ЗЛОЧИННИМ ШЛЯХОМ
}

\author{
Коваль Яна Сергї̈вна, \\ кандидат наук з державного управління, \\ дочент кафедри управління фінансово-економічною безпекою, \\ ВНЗ «Університет економіки та права «КРОК», \\ ORCID: https://orcid.org/0000-0001-6578-2996
}

Анотація. У розділі досліджено основні принципи та методи боротьби з легалізацією (відмиванням) доходів, одержаних злочинним шляхом. Така боротьба $є$ важливим складником формування вищого рівня визначеності економічних відносин усередині країни та в міжнародних стосунках. Ідентифіковано функції міжнародних організацій, які координують роботу в сфері запобігання та протидії легалізації (відмиванню) доходів. Розглянуто основні схеми легалізації (відмивання) доходів, одержаних злочинним шляхом. Визначено пріоритети застосування досвіду інших країн у реформуванні української системи фінансового моніторингу.

Ключові слова: доходи, одержані злочинним шляхом, фінансовий моніторинг, механізми протидії легалізації доходів, бенефіціар, національна оцінка ризиків.

Сучасні зміни у національних системах фінансового моніторингу в різних країнах світу визначаються необхідністю легалізації доходів, одержаних злочинним шляхом, та фактами фінансування тероризму. Як показує досвід різних країн, поряд 3 державними органами, що здійснюють збір податків та платежів, питаннями фінансової безпеки опікуються й спеціалізовані фінансові інституції. Йдеться про проблему легалізації (відмивання) доходів, одержаних злочинним шляхом, що набула ознак міжнародної. Різні схеми «відмивання» грошей стають транснаціональними. Вони пов'язані 3 організованою злочинністю (фінансовими аферистами, наркобізнесом, фінансуванням тероризму тощо). Аналізована нами проблема пов'язана з загрозами фінансовоекономічній безпеці та економічній стабільності. Дослідження досвіду протидії легалізації (відмиванню) доходів, одержаних злочинним шляхом, $\epsilon$ актуальним, з огляду на можливість його застосування в Україні.

Метою дослідження є компаративний аналіз методів протидії легалізації (відмивання) доходів, одержаних злочинним шляхом, для визначення можливостей застосування їх використання в українській економіці. 
У сучасному світі спостерігається удосконалення способів скоєння злочинів та методів приховування їх негативних наслідків. Розвиток новітніх технологій призвів до правопорушень 3 використанням сучасних комунікацій. До злочинних дій, скоєння яких відбувається з використанням технічних результатів наукового прогресу, належить і легалізація доходів, отриманих незаконним шляхом.

Для попередження ухилення від сплати податків та інших фінансових злочинів створюються підрозділи фінансової розвідки. Вони виконують аналітичні функції збору й обробки інформації. Відмінності між підрозділами фінансової розвідки визначаються специфікою їх діяльності, функціональними можливостями тощо. Проте всі згадані підрозділи мають бути орієнтовані на координацію діяльності.

У деяких країнах підрозділи фінансової розвідки $\epsilon$ адміністративними органами, в інших - діють в якості поліцейських та юридичних органів. Досвід країн з розвиненими фінансовими розвідками свідчить про те, що ефективність їх роботи визначається лише наявністю визначеної правової бази й ефективністю системи збору, обробки, передачі та надання фінансової інформації, ідентифікації ініціаторів фінансових операцій [1].

Відмивання «брудних» грошей є складним економіко-правовим явищем, яке не має кордонів. Термін «відмивання грошей» з'явився в науковому обігу порівняно нещодавно. Проте світова спільнота уже встигла продемонструвати серйозність своїх намірів у боротьбі з цим злом.

Шляхи передачі інформації в різних країнах суттєво впливають на ефективність фінансового моніторингу загалом. Лише прямі канали передачі інформації від підрозділів фінансової розвідки до фінансових інститутів та регуляторів сприяють ефективності фінансового моніторингу. У випадку передачі інформації від фінансових посередників до державних регуляторів у сфері фінансів, а потім до підрозділів фінансової розвідки ефективність національної системи фінансового моніторингу значно зменшується.

Глобалізаційні та інтеграційні процеси, стрімкий розвиток інформаційних технологій призвели до того, що проблема легалізації злочинних доходів вийшла на міжнародний рівень.

На сьогодні легалізації доходів властиве постійне ускладнення схем, прискорення проведення незаконних операцій, а також потреба у використанні транзитних банківських рахунків. Це призводить як до серйозних втрат економічних ресурсів, так і репутації банків. Загальні масштаби такої загрози для банківського сектору можна охарактеризувати кількістю вжитих до них санкцій. Саме санкції вказують на їх причетність до легалізації доходів, отриманих незаконним шляхом, та на невиконання вимог законодавства в цій сфері [2]. 
Механізми протидії легалізації доходів незаконного походження у фінансових організаціях повинні безперервно вдосконалюватися. Це дозволить якісно аналізувати інформацію, яка надходить, своєчасно виявляючи в ній відомості про операції, пов'язані з легалізацією злочинних доходів, забезпечувати фінансову безпеку банку, сприяти раціональному використанню його ресурсів та досягненню стратегічних цілей.

Широкомасштабне «відмивання» нелегальних доходів загальносвітова проблема, яка вимагає рішення з боку всіх держав світу. Для початку кожна держава повинна самостійно визнати це діяння злочинним і внести відповідні зміни й доповнення у внутрішне законодавство. Саме від цього буде залежати успіх боротьби з цим серйозним і небезпечним видом злочинів в усьому світі.

Ефективне міжнародне співробітництво у сфері боротьби 3 тероризмом 3 урахуванням цих негативних процесів неможливе без скоординованої роботи міжнародної спільноти. Йдеться про характер сучасного тероризму. Він вимагає глобального реагування на такі виклики на засадах міжнародної співпраці й кооперації [3].

Аналіз становлення правового регулювання співробітництва держав-членів Свропейського Союзу з протидії легалізації доходів, отриманих злочинним шляхом, $є$ надзвичайно актуальним. Це дає можливість прослідкувати еволюцію такої співпраці та шляхи вдосконалення форм і механізмів колективної діяльності держав у цій сфері. Такі механізми одночасно можуть стати взірцем кращих практик, спрямованих на підвищення ефективності як національних заходів із боротьби з відмиванням «брудних» грошей, так і тих, які можуть бути застосовані в інших регіональних утвореннях.

Як правило, міжнародне співробітництво у сфері боротьби 3 тероризмом здійснюється шляхом:

- встановлення на міжнародному рівні єдиних підходів щодо притягнення до кримінальної відповідальності за тероризм та його прояви;

- розробки та укладання міжнародних договорів у сфері боротьби 3 тероризмом, прийняття інших міжнародних документів як правової основи регулювання діяльності держав, міжнародних організацій у цій сфері [4].

Практично ця діяльність може мати характер співробітництва у сфері вироблення єдиної державної політики щодо запобігання тероризму, оперативного обміну інформацією між органами кримінальної юстиції, кримінального переслідування терористів і притягнення їх до відповідальності. 
Міжнародне співробітництво у боротьбі з сучасним тероризмом грунтується на таких принципах:

- принцип осуду тероризму, незалежно від цілей терористів, що закріплено практично в усіх міжнародних конвенціях про боротьбу 3 тероризмом;

- відмова від будь-яких форм (фінансова, військово-технічна та ін.) сприяння терористам;

- співробітництво на світовому рівні в боротьбі з фінансовими й технологічними можливостями сучасного тероризму;

- захист світових культур і релігій від екстремістського впливу тероризму;

- дотримання норм міжнародного права [5].

«Відмивання» незаконно отриманих доходів завжди відбувається не в країні, де знаходиться їх джерело походження, а за кордоном. Саме цей факт зумовлює розвиток міжнародного співробітництва у боротьбі з «відмиванням» грошей. Він базується на таких принципах:

- прийняття відповідних міжнародних і національних нормативноправових актів;

- укладання угод про правову допомогу в боротьбі 3 «відмиванням» грошей;

- розробка міжнародних програм протидії «відмиванню» грошей;

- прийняття відповідних документів міжнародними економічними, фінансовими, політичними і правоохоронними організаціями, економічними союзами;

- створення спеціальних міжнародних та національних правових і силових структур;

- упровадження певних правил з обміну іноземної валюти;

- посилений нагляд за офшорними секторами економіки;

-удосконалення електронного архіву міжнародних грошових переказів;

- створення програм з навчання фахівців банківської сфери;

- встановлення міжнародних стандартів бухгалтерського обліку та механізмів контролю за їх дотриманням;

- публікація «чорних» списків країн;

-блокування банківських активів при виявленні підозрілих операцій;

-випуск спеціальних міжнародних видань 3 проблематики «відмивання» грошей [6].

Існує ціла система протидії легалізації грошей, аспекти якої зображені на рис. 1. 


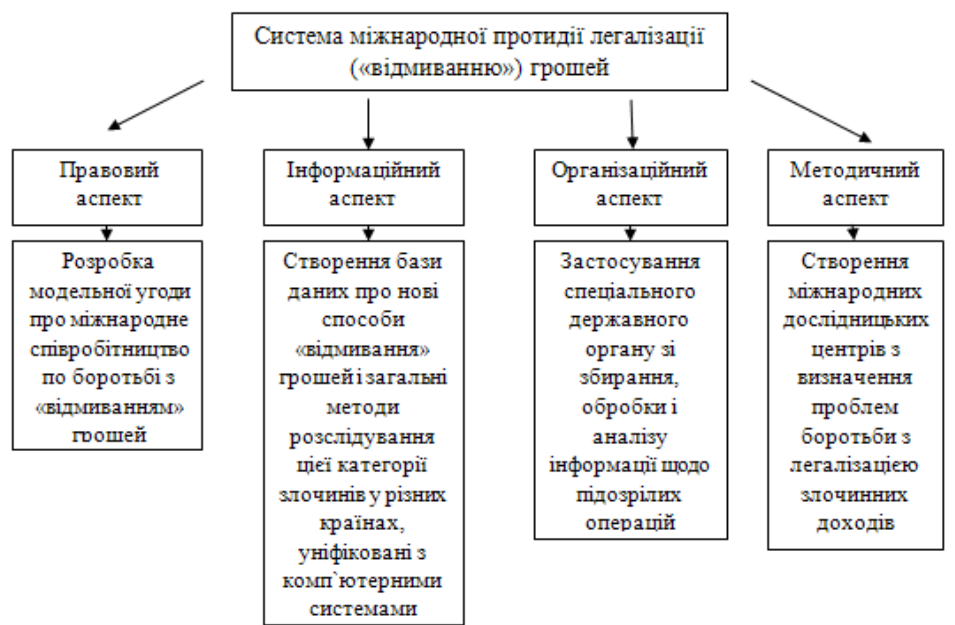

Рис. 1. Система міжнародної протидії легалізації («відмиванню») доходів, одержаних злочинним шляхом

Джерело: сформовано автором на основі [7-12].

Доцільно розглянути більш детально зарубіжний досвід.

Сполучені Штати Америки, як країна 3 провідною економікою світу, одні з перших почали вживати заходів щодо легалізації злочинних доходів. Керівні органи країни створили систему протидії різним схемам 3 легалізації доходів, одержаних злочинним шляхом. Важливим елементом цієї системи стало формування законодавчої бази щодо регулювання діяльності фінансових інститутів.

Більшість експертів початок боротьби з легалізацією доходів у США датують 1970 р., тобто прийняттям Закону «Про банківську таємницю». Цей Закон визначав зобов'язання фінансових установ зберігати облікову документацію про проведені операції. Таким чином, були закладені передумови розвитку системи фінансового моніторингу в США. А вже у 1986 р. дії, спрямовані на «відмивання» грошей, були юридично класифіковані як злочин, відповідно до прийнятого Закону «Про контроль над відмиванням грошей».

Основним законом, який регулює особливості здійснення фінансового моніторингу в США, $є$ PATRIOT Act 2001. Його основною метою $є$ обмеження доступу до фінансової системи США шляхом уведення більш суворих вимог стосовно іноземних фінансових інститутів, що відкривають кореспондентські рахунки в американських банках. У зв'язку з цим усі американські фінансові інститути повинні розробляти та вдосконалювати програми для виявлення операцій 3 відмивання грошей [13]. 
У разі порушення законодавства у сфері протидії легалізації доходів, отриманих злочинним шляхом, та фінансуванню тероризму адміністративну та/чи кримінальну відповідальність у США несуть не тільки злочинці, а й суб’ єкти фінансового моніторингу. Зокрема, американський банк, що обслуговує рахунок нерезидента, зобов'язаний припинити всі відносини з іноземним контрагентом не пізніше ніж через 10 робочих днів після одержання письмового повідомлення від Міністра фінансів чи Генерального Прокурора про те, що іноземний банк відмовився відповісти на запит, і почати процесуальні дії в суді США зі встановленню правомочності цього запиту. Відмова завершити кореспондентські відносини в рамках вищевказаних умов погрожує санкцією у відношенні до американського фінансового інституту у вигляді штрафів у розмірі до 10 тис. дол. за кожний день, доти, поки ці відносини не будуть припинені.

У банківській сфері США протидією легалізації злочинних доходів займаються такі контрольні органи:

- Апарат ревізора з грошового обігу;

- Федеральна корпорація зі страхування вкладів;

- Правління Федеральної резервної системи;

- Управління з контролю за дотриманням законності;

- Національна адміністрація кредитної спілки [14].

Зазначені відомства розробили спеціальні методики для розпізнавання можливих порушень і злочинної діяльності в банківській сфері. Під час проведення перевірки банківських структур названі вище органи контролю можуть зосередити увагу на фактах потенційного шахрайства, внутрішніх зловживань та інших злочинних діях, у тому числі пов'язаних 3 відмиванням грошей. Для перевірки дотримання Закону «Про банківську таємницю» або розслідування можливих порушень будь-яких інших нормативно-правових актів ці відомства можуть здійснювати банківські ревізії. Наприклад, Федеральна корпорація зі страхування вкладів створила свій відділ з економічних злочинів, до якого ввійшли спеціально підготовлені інспектори 3 вивчення можливої злочинної діяльності.

Таким чином, на сьогодні у США створена одна 3 найбільш ефективних систем протидії легалізації доходів та фінансування тероризму. Це зумовлено, на наш погляд, насамперед тим, що США, маючи одну з провідних економік світу, володіють широкою мережею як кредитних організацій міжнародного рівня, так і кредитних організацій, що популярні більше на внутрішньому ринку США.

У Франції організацію фінансового моніторингу регулюють два основних нормативно-правових акти: Закон «Про участь фінансових інститутів у боротьбі з відмиванням грошей від незаконного обігу наркотиків» та Валютно-фінансовий кодекс. 
Спеціальним підрозділом фінансової розвідки у Франції є TRACFIN. Він підпорядковується Міністерству фінансів, а його діяльність $€$ засекреченою [15].

Особливістю системи фінансового моніторингу у Франції є те, що вона не має законодавчо закріплених вимог щодо надання інформації про фінансові операцій в залежності від їх суми. Критеріями дослідження операцій на сумнівність $є$ вмотивована підозра щодо фінансових операцій, які мають ознаки легалізації доходів. Ідеться про кошти, які можуть стосуватися незаконної торгівлі наркотиками, організованої злочинності, вчинення шахрайських дій, корупції. Особливої уваги від суб'єктів первинного фінансового моніторингу потребують фінансові операції. Йдеться про суми, які перевищують 150 тис. євро та характеризуються складністю проведення або відсутністю економічного сенсу.

Надавати інформацію до TRACFIN про нетипові фінансові операції зобов'язані фінансові інститути: банки та кредитні установи, платіжні організації, страховики, інвестиційні компанії, ломбарди. Також це здійснюють фізичні й юридичні особи, які професійно займаються фінансовою та пов'язаною з нею діяльністю: посередники з нерухомості, власники казино, клуби і компанії, що організовують азартні ігри, лотереї, спортивні ігри, суб'єкти, які здійснюють торгівлю дорогоцінностями, антикваріатом, творами мистецтва, бухгалтери, аудитори, нотаріуси, судові виконавці, керівники та законні представники, компанії з продажу майна на публічних торгах й інші [16]. Фінансовий моніторинг у Німеччині здійснює підрозділ фінансової розвідки (Zentralstelle für Verdachtsanzeigen), який входить до складу поліції.

Фінансово-кредитні установи у Німеччині зобов'язані здійснювати ідентифікацію клієнта й у випадку перевищення суми фінансової операції 15 тис. євро (або у випадку встановлення довгострокових відносин), і у випадку, якщо фінансова операція викликає мотивовану підозру щодо відмивання кримінальних доходів. Окрім ініціатора фінансової операції, фінансові установи Німеччини зобов'язані встановлювати особу бенефіціара підозрілої операції.

Цікавим є той факт, що Центральний банк у Німеччині (Бундесбанк) не має повноважень регулювання та нагляду в сфері протидії легалізації доходів, отриманих злочинним шляхом та фінансуванню тероризму. Сам банк належить до фінансових установ, які здійснюють комерційні фінансові операції. Таким чином, Бундесбанк, як й інші фінансовокредитні установи Німеччини, зобов'язаний звітувати про підозрілі фінансові операції [17].

Нагляд за діяльністю фінансових установ у Німеччині здійснює Федеральне відомство нагляду за діяльністю фінансових установ (BaFin). Окрема Група нагляду за здійсненням фінансовими установами 
заходів щодо запобігання легалізації кримінальних доходів у складі BaFin включає 4 сектори: політичних рішень і міжнародного співробітництва; перевірок банківських установ; перевірок страховиків та установ, що здійснюють.

Особливу увагу протидії відмиванню злочинних доходів та фінансуванню тероризму з метою забезпечення фінансової безпеки приділяють у Канаді. За даними підрозділу фінансової розвідки Канади Financial Transaction and Report Analysis Center (FINTRAC), щорічний обсяг злочинних доходів у світі коливається в межах 590 млрд - 1,5 трлн дол. США. Тому повноваження FINTRAC щодо протидії легалізації незаконних доходів розповсюджуються на всі види фінансових злочинів, у тому числі торгівлю наркотиками, фінансові махінації, ухиляння від сплати податків, корупцію та інші [18].

FINTRAC, який підпорядковується Міністерству фінансів Канади, було створено у 2000 р. відповідно до Закону Канади «Про протидію відмиванню незаконних коштів та фінансуванню тероризму». У 2002 році FINTRAC став членом Егмонтської групи підрозділів фінансової розвідки. Сьогодні FINTRAC співпрацює з більш як 100 підрозділами фінансових розвідок різних країн щодо обміну інформацією та досвідом у сфері протидії легалізації доходів, отриманих злочинним шляхом та фінансуванню тероризму.

Метою діяльності FINTRAC є сприяння громадській безпеці Канади й захист цілісності фінансової системи країни шляхом виявлення та запобігання легалізації доходів і фінансування тероризму.

Як зазначає дослідник Іваницька О. М., специфічною ознакою діяльності фінансового моніторингу в Канаді є багатоджерельність отримання інформації. Основними джерелами інформації, що використовують у процесі фінансового моніторингу FINTRAC, є: добровільно надана інформація (59\%), повідомлення про підозрілі операції (13\%), профільні доповіді (5\%), інформація з відкритих джерел (3\%) та запити підрозділів фінансової розвідки (20\%) [19].

Тобто зі всієї кількості отриманої інформації щодо відмивання злочинних доходів лише $13 \%$ становить інформація, яку зобов'язані подавати фінансові установи та інші суб'єкти первинного фінансового моніторингу. Це свідчить про високий рівень організації фінансового моніторингу і фінансової системи загалом та високий рівень свідомості суб'єктів, які ініціюють чи здійснюють фінансові операції.

У разі порушення законодавства у сфері протидії легалізації злочинних доходів і фінансуванню тероризму в Канаді застосовують як штрафні санкції до 2 млн дол. США, так і відповідальність у вигляді позбавлення волі до 5 років.

Система фінансового моніторингу в Канаді постійно перебуває в стадії динамічного розвитку. Останні напрями іiї удосконалення 
спрямовані на розробку єдиної національної системи оцінки ризиків легалізації злочинних доходів із упровадженням нормативного процесу оцінки ризиків для окремих секторів фінансової системи та окремих продуктів сфери фінансових послуг.

У Польщі основний Закон «Про протидію відмиванню грошей та фінансуванню тероризму» в сфері протидії легалізації злочинних доходів було прийнято у 2000 р. Згідно з чинним законодавством Польщі обов'язковому фінансовому моніторингу підлягають фінансові операції на суму, що в еквіваленті становить 15 тис. євро та більше.

Центральним елементом системи державного фінансового моніторингу в Польщі $є$ Генеральний інспектор фінансової інформації (Generalny Inspektor Informacji Finansowej - GIIF), підпорядкований Міністерству фінансів. Мета GIIF - отримання, збирання, обробка та аналіз інформації для запобігання легалізації активів незаконного або невизначеного походження і запобігання фінансуванню тероризму. Вчинення злочину щодо легалізації будь-яких активів, отриманих у незаконний спосіб, у Польщі карається позбавленням волі від 6 місяців до 10 років з можливою конфіскацією майна [20].

У Білорусі на законодавчому рівні та в політичній сфері відсутня єдина стратегія боротьби з легалізацією доходів, отриманих злочинним шляхом, а фінансовий моніторинг розглядають як частину інших державних програм. Єдиний координаційний орган - підрозділ фінансової розвідки - відсутній. Частину його обов'язків виконує Департамент фінансового моніторингу Комітету державного контролю Республіки Білорусь. Більшість (98\%) повідомлень про підозрілі фінансові операції передаються в електронній формі від банківських установ, а решта - у паперовій формі. Їх потім вручну вносять до системи. Як визначено у звіті Комітету державного контролю Республіки Білорусь, Департамент фінансової розвідки, інші правоохоронні органи та прокуратура не надають регулярно державному фінансову моніторингу зворотній зв'язок про використання переданих матеріалів [21].

В Італії фінансовий моніторинг покладено на Ufficio Italiano Combi UIC (SAR), що підпорядковується Національному банку Італії. Першою та другою частиною положення про фінансові операції i звітністю Національного Банку Італії визначено правила проведення фінансового моніторингу фінансовими установами на всій території Італії. Чинне законодавство країни передбачає ведення банками й іншими фінансовими посередниками детальної документації щодо всіх валютних операцій клієнтів-резидентів. У 2014 р. до UIC (SAR) надійшло 49 тис. доповідей про підозрілі фінансові операції.

У Великій Британії питаннями фінансового моніторингу опікується підрозділ фінансової розвідки - Служба внутрішніх доходів NCIS / ECU. Вона підпорядковується Міністерству фінансів Великої Британії 
та взаємодіє з Національною службою кримінальної розвідки, Митноакцизною службою, Бюро для боротьби 3 шахрайством, Службою національних розслідувань. NCIS / ECU Великої Британії займається питаннями протидії легалізації доходів, фінансування тероризму, злочинів у сфері грального бізнесу, шахрайств. Проте англійське законодавство забороняє передачу інформації про податкові правопорушення іншим державам. 32005 р. у національній системі фінансового моніторингу Великої Британії намітилися тенденції до посилення координації діяльності всіх учасників протидії легалізації доходів [22].

У зв'язку з тим, що процес легалізації (відмивання) доходів, одержаних злочинним шляхом, реалізується переважно 3 використанням міжнародних злочинних зв'язків, були створені спеціальні міжнародні організації, які здійснюють координацію роботи у сфері запобігання та протидії легалізації злочинних доходів. Такими організаціями на сьогоднішній день $є$ :

1. Група з розробки фінансових заходів боротьби з відмиванням грошей (FATF) - міждержавна організація, створена у липні 1989 р. на нараді керівників країн Великої Сімки у Парижі «для оцінки поточних результатів співпраці у сфері запобігання використання банківської системи і фінансових установ для відмивання доходів, одержаних злочинним шляхом, та розгляду можливості прийняття додаткових превентивних заходів у даній сфері».

2. Егмонтська група (Група підрозділів фінансової розвідки «Егмонт») - неформальне об'єднання національних відомств, що виконують функції фінансової розвідки, створене у червні 1995 р. у Брюсселі представниками 24 країн та низки міжнародних органів, включаючи FATF, Інтерпол, Європейську комісію, Всесвітню митну організацію та ін. Членство в ЕГ є однією з вимог рекомендацій FATF.

3. MONEYVAL - спеціальний комітет експертів PС 3 питань взаємної оцінки заходів протидії відмиванню коштів та фінансуванню тероризму, створений у вересні 1997 р. рішенням Комітету Міністрів Р€ для здійснення загального й незалежного аналізу боротьби 3 легалізацією злочинних коштів у країнах-членах Р€ (і країнах-кандидатах на вступ до РЕ), які не є членами FATF.

4. Євразійська група 3 протидії легалізації злочинних доходів і фінансуванню тероризму (САГ) - об'єднання, створене у жовтні 2004 p. шляхом підписання Декларації офіційними представниками урядів Республік Білорусь, Казахстан, Киргизстан, Таджикистан, Китаю, Російської Федерації за типом FATF.

5. Базельський комітет (Комітет регулювання та нагляду за банківською діяльністю) - спеціальний орган, створений у 1974 р. під егідою Банку міжнародних розрахунків на основі укладеної 10-ма розвиненими країнами угоди (так званий Базельський конкордат). 
6. Вольфсберзька група - міжбанківське об'єднання, створене у 2000 p. 11-ма найбільшими банками світу.

7. ООН - міжнародна організація, яка об'єднує 192 країни світу. Статут ООН був підписаний 26 червня 1945 р. на конференції в СанФранциско (США) і вступив у силу 24 жовтня 1945 р.

8. Міжнародний валютний фонд - універсальна міжнародна фінансова організація, заснована відповідно до угод, прийнятих на Міжнародній валютно-фінансовій конференції ООН у липні 1944 р. у США, та набула чинності з грудня 1945 р.

9. Світовий банк - одна 3 найбільших у світі організацій, що надають допомогу з метою розвитку, заснована у $1944 \mathrm{p}$.

10. Свропейський банк реконструкції та розвитку - банк 3 найбільшими обсягами залучених прямих іноземних інвестицій, а відтак, $\epsilon$ найбільшим інвестором у регіоні, створений у 1991 р.

11. Міжнародна організація кримінальної поліції (Інтерпол) спеціальний орган з центром у Відні, який бере безпосередню участь у боротьбі зі злочинністю [23].

Враховуючи вищезазначене, необхідно акцентувати, що у сучасному світі реалізуються різні схеми легалізації (відмивання) злочинних коштів. Єдиної класифікації таких схем як серед науковців, так і правоохоронних органів немає. Однак, на основі спільних характерних ознак їх можна згрупувати за такими критеріями:

а) за призначенням:

- 3 метою ухилення від сплати податків;

- 3 метою приховування злочинних операцій (легалізації засобів, одержаних від злочинів);

б) за типами систем розрахунків:

- готівкові;

- безготівкові (через платіжні доручення, пластикові картки, клірингові розрахунки тощо);

в) за організацією управління:

- 3 централізованим управлінням («конвертаційні центри») [24].

Для такої схеми характерна значна кількість злочинних операцій. Схема успішно функціонує за наявності централізованої ланки, яка організовує проведення операцій, що пов'язані 3 одержанням та передачею грошових коштів, здійснює контроль за роботою залежних фірм, веде облік тощо. Центральна ланка також виконує функцію захисту від правоохоронних органів. У випадку усунення або обмеження діяльності центральної ланки (наприклад, арешт керівників, банкрутство головної багатофіліальної фірми тощо) схема припиняє роботу.

Методи з централізованим управлінням характеризується ретельним забезпеченням функцій взаємодії між учасниками i, як правило, тим, що більшість фінансових ресурсів зосереджується саме в центральній 
ланці. Коли фінансові ресурси рівномірно розподілені по різних фірмах, централізоване управління $\epsilon$ неефективним. Воно не забезпечує необхідної надійності процесу відмивання коштів. Як наслідок, посилюється ризик конфліктів через невиконання своїх зобов'язань - 3 децентралізованим або розподіленим управлінням.

Для такої схеми характерний розподіл функцій управління між окремими фірмами, що поєднують лише разові операції або банк, через який здійснюються платіжні трансакції. У децентралізованій схемі легалізації (відмивання) злочинних коштів, порівняно з централізованою, мають місце проблеми захисту від правоохоронних органів.

г) за способом організації передачі інформації:

- 3 маршрутизацією інформації.

Взаємодія учасників схеми забезпечує визначення шляхів передачі злочинних коштів у різних формах за адресами їх призначення. Цей процес, як правило, виконується всіма учасниками системи.

- з селекцією інформації.

Взаємодія учасників схеми здійснюється через селекцію (відбір) адресованих їм різних форм злочинних коштів.

д) за технічним забезпеченням проведення фінансових розрахунків (методами доступу для проведення електронних трансакцій):

- 3 єдиними методами доступу, орієнтованими на електронні розрахунки (система «клієнт-банк», пластикові картки тощо);

- 3 використанням різних носіїв грошових коштів (готівка, пластикові картки, цінні папери тощо) [25].

Тип носія визначає властивості фінансової трансакції, яка здійснюється через організацію обміну певними зобов'язаннями. Найпростішим технічним засобом $є$ телефонна лінія. Ідеться про зниження вартості фінансової трансакції, по-перше, через невисоку вартість самого носія, по-друге, завдяки наявності на багатьох об' єктах резервних телефонних ліній, що можуть за необхідності використовуватися. До недоліків телефонних каналів здійснення злочинної фінансової трансакції з відмивання коштів належать недостатня захищеність від технічних перешкод, можливість несанкціонованого підключення (як правоохоронних органів, так і конкуруючих злочинних організацій), обмеження дальності й швидкості передачі даних наборами тих або тих компонентів електронної підтримки телефонної лінії.

Окрім того, проведений аналіз особливостей операційної діяльності 3 відмивання коштів дозволяє виділити типові схеми легалізації (відмивання) доходів, одержаних злочинним шляхом, які використовуються у сучасному світі. Нижче проаналізуємо кожну з них детальніше.

1. Легалізація (відмивання) коштів шляхом незаконної конвертації грошових коштів з використанням фіктивних підприємств.

2. Легалізація (відмивання) коштів шляхом здійснення спекулятивних операцій з цінними паперами. 
3. Легалізація (відмивання) коштів шляхом здійснення шахрайських операцій з землею та об' сктами нерухомості.

4. Легалізація (відмивання) коштів у результаті незаконного відшкодування з бюджету ПДВ та у процесі приватизації державного майна.

5. Легалізація (відмивання) коштів за участю банківських установ.

6. Легалізація (відмивання) коштів за участю небанківських фінансових установ.

7. Легалізація (відмивання) коштів з використанням САГП.

8. Легалізація (відмивання) коштів з використанням віртуальних валют.

9. Легалізація (відмивання) коштів з використанням Інтернетказино [26].

Проаналізовані схеми та методи легалізації (відмивання) доходів, одержаних злочинним шляхом, вказують на те, що відмивання коштів є злочином глобального характеру. Це пов'язано з тим, що суб'єкти легалізації (відмивання) коштів, виводячи свою діяльність на міжнародний рівень, переслідують такі цілі:

- уникнення країн/територій з чіткою нормативно-правовою базою та потужною правоохоронною системою;

- використання недоліків нормативної бази та роботи правоохоронних органів, характерних для низки юрисдикцій;

- використання прогалин, які існують при недостатньому рівні співпраці між правоохоронними органами різних країн;

- створення додаткових нашарувань транзакцій для того, щоб ускладнити відстеження руху злочинних доходів [27].

В останньому випадку часто використовуються країни, на території яких діють закони про таємницю проведення фінансових операцій. Такі юрисдикції називають «фінансовими притулками» або «офшорними зонами». Вони являють собою всю або частину території країни, де встановлюється і використовується пільговий режим функціонування компаній з офшорним статусом. Ідеться про ведення діяльності поза межами території реєстрації та проведення операції з майном чи коштами нерезидентів. Невеликі країни заохочують створення на своїй території офшорних компаній. Вони розвивають офшорний бізнес, який приносить цим країнам додаткові прибутки.

Вище проаналізовані схеми та методи складають далеко неповний перелік типових схем легалізації (відмивання) доходів, одержаних злочинним шляхом. 3 кожним роком вони стають більш складними та розгалуженими. Тому, необхідно запровадити порядок оприлюднення інформації про розкриті схеми легалізації (відмивання) коштів. Потрібно розробити методичні рекомендації щодо заходів, які будуть спрямовані, 3 одного боку, на попередження таких схем, а з іншого - на своєчасне їх 
виявлення. Доцільно також створити єдину електронну базу даних про суб'єктів таких схем, а також визначити типові параметри підозрілості осіб та операцій з легалізації (відмивання) доходів, одержаних злочинним шляхом.

В Україні система фінансового моніторингу перебуває у стадії формування та розвитку. Про переймання світового досвіду в сфері протидії легалізації злочинних доходів свідчить постійне вдосконалення законодавчої бази. Зокрема, 28 квітня 2020 р. Верховна Рада внесла зміни до Закону України «Про запобігання та протидію легалізації (відмиванню) доходів, одержаних злочинним шляхом, фінансуванню тероризму та фінансуванню розповсюдження зброї масового знищення» №361-IX. Він має суттєві доопрацювання порівняно 3 попереднім Законом, який втратив чинність [28].

До суттєвих удосконалень новоприйнятого Закону варто віднести більш деталізоване визначення дій, які можливо кваліфікувати як легалізацію (відмивання) доходів, одержаних злочинним шляхом, а також, удосконалено національне законодавство у сфері фінансового моніторингу. Також Законом розширено перелік суб'єктів первинного фінансового моніторингу, до яких додаються страхові (перестрахові) брокери, розповсюджувачі державних лотерей, адвокатські бюро та об’єднання, суб'єкти господарювання, що надають послуги 3 бухгалтерського обліку.

Організація ефективної системи запобігання та протидії легалізації доходів, одержаних злочинним шляхом, як у національному, так i міжнародному масштабах здатна істотно знизити мотивацію в одержанні таких доходів, виявляти і знищувати джерела їх походження, i, відповідно, скоротити кількість здійснюваних протиправних дій. У зв’язку з цим, запобігання та протидія легалізації доходів, одержаних злочинним шляхом, стали одними з найважливіших завдань як кожної окремо взятої країни, так і всього міжнародного співтовариства.

Водночас, існують сфери діяльності, у яких недоліки в організації фінансового моніторингу в Україні виявляються найбільш очевидно. Вони подані на рис. 2.

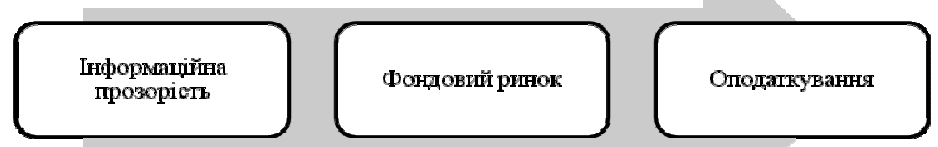

Рис. 2. Сфери, які виявляють найбільші недоліки в організації фінансового моніторингу в Україні

Джерело: сформовано автором на основі [29-32] . 
На території України відбуваються такі позитивні зміни:

- впроваджуються стандарти СС у боротьбі з відмиванням грошей та фінансуванням тероризму, спрямовані на подальшу імплементацію відповідного законодавства згідно зі стандартами СС;

- продовження взаємодії підрозділів фінансових розвідок України відповідно до стандартів групи Егмонта;

- збільшення спроможностей державних установ 3 визначення порядку та здійснення ефективного нагляду за фінансовими посередниками і представниками нефінансових професій;

- продовження обміну інформацією між підрозділами фінансових розвідок країн - членів СС та України про підозрілі фінансові операції, що можуть мати стосунок до відмивання грошей;

- продовження надання підтримки у навчанні суддів, працівників прокуратури, митників, співробітників правоохоронних органів та інших фахівців з фінансового моніторингу; продовження співробітництва в рамках роботи Комітету Moneyval Ради Свропи для забезпечення підтримки високих стандартів у процесі спільної оцінки всіх його членів та у типологічній роботі [33].

На підставі дослідження специфіки проведення фінансового моніторингу в світі можна визначити найбільш перспективні напрямки використання окремих особливостей світового досвіду в національній системі фінансового моніторингу в Україні (табл. 1).

Таблиця 1

\section{Напрямки використання світового досвіду в процесі реформування національної системи фінансового моніторингу в Україні}

\begin{tabular}{|c|l|}
\hline Країна & \multicolumn{1}{|c|}{ Особливість, що може бути використана в Україні } \\
\hline Канада & $\begin{array}{l}\text { перенесення на наступний бюджетний період невикористаних планових } \\
\text { бюджетних коштів }\end{array}$ \\
\hline США & $\begin{array}{l}\text { широка координація взаємодії органів, що протидіють легалізації доходів, } \\
\text { отриманих злочинним шляхом, та фінансування тероризму }\end{array}$ \\
\hline Італія & $\begin{array}{l}\text { підпорядкування фінансового моніторингу центральному банку, автоматизована } \\
\text { ризико-орієнтована система обробки інформації }\end{array}$ \\
\hline Австралія & $\begin{array}{l}\text { поєднання для реалізації фінансового моніторингу напрямків не лише протидії } \\
\text { легалізації доходів, отриманих злочинним шляхом, та фінансування тероризму, } \\
\text { ай ухилення від сплати податків }\end{array}$ \\
\hline Китай & $\begin{array}{l}\text { розмежування між окремими структурними підрозділами функцій управління та } \\
\text { реалізації фінансового моніторингу в рамках єдиного уповноваженого органу }\end{array}$ \\
\hline Фінляндія & відповідальність уповноваженого органу за процес попереднього розслідування \\
\hline Бельгія & $\begin{array}{l}\text { покладання на законодавчому рівні на уповноважений орган в сфері протидії } \\
\text { легалізації доходів, отриманих злочинним шляхом, та фінансування тероризму } \\
\text { функцій координації діяльності органів фінансового моніторингу }\end{array}$ \\
\hline $\begin{array}{c}\text { Велика } \\
\text { Британія }\end{array}$ & заборона передачі інформації про податкові правопорушення іншим державам \\
\hline
\end{tabular}

Джерело: сформовано автором на основі [34-36]. 


\section{Висновки:}

Дослідивши зарубіжну практику, передусім американський досвід протидії легалізації доходів незаконного походження, можна зробити висновок про можливість створення ефективної системи. Ефективність такої системи забезпечується не лише чинним законодавством, а й невідворотним виконанням його норм. Організаційні основи системи фінансового моніторингу в Україні загалом відповідають кращим світовим стандартам та рекомендаціям міжнародних організацій у цій сфері.

Існує низка переваг систем фінансового моніторингу в окремих країнах, які варто було б застосувати в Україні. Зокрема, зважаючи на досвід США та Канади, доцільно до фінансових злочинів в Україні віднести операції з предикатними до легалізації злочинами. Йдеться про комп'ютерне шахрайство, незаконні кредитні операції, підробку платіжних карток та інших платіжних документів, корупцію і зловживання службовим становищем, ухиляння від сплати податків. За прикладом США та Канади, в Україні доцільно посилити міжвідомчу координацію органів, які здійснюють нагляд у сфері протидії легалізації злочинних доходів. Необхідно створити закриту єдину систему для обміну інформацією щодо легалізації доходів між різними органами.

За прикладом Канади, Франції, США, доцільно забезпечити механізми збереження отриманої інформації у таємниці. Дотримання таємниці, зокрема, досягається за рахунок посилення адміністративної відповідальності уповноважених для роботи з секретною інформацією. Можливе застосування щодо окремих осіб таких заходів, як штрафні санкції, заборони обіймати керівні посади тощо.

За прикладом Канади, можливе розширення джерел отримання інформації в межах Державного фінансового моніторингу. Йдеться про інформацію щодо підозрілих операцій, отриманих 3 аналітичних доповідей, відкритих джерел масової інформації, яка ставатиме причиною більш глибоких досліджень спеціальних органів.

Необхідно посилити відповідальність суб'єктів первинного фінансового моніторингу за порушення законодавства у сфері протидії легалізації злочинних доходів. Зокрема так, як це відбувається у США, де комерційні банки сплачують по 10 тис. дол. за кожен день продовження відносин 3 клієнтами, які не подають необхідної інформації. Для порівняння: в Україні максимальний розмір штрафу для суб'єктів первинного фінансового моніторингу - юридичних осіб - становить близько 2,5 тис. дол. США за повторні порушення.

Доцільно посилити персональну відповідальність посадових осіб суб'єктів первинного фінансового моніторингу. За чинним законодавством, передбачено лише тимчасове відсторонення від посади до моменту усунення порушення. 


\section{Jimepamypa:}

1. Доля Л. М. Легалізація («відмивання») доходів, отриманих злочинним шляхом, як міжнародна проблема. Боротьба з організованою злочинністю і корупцією (теорія і практика). 2001. №4. С. 51-56.

2. Гулько Л. Г., Ільєва О. В. Організаційно-економічний механізм фінансового моніторингу в суб' єктів первинного фінансового моніторингу. Глобальні та національні проблеми економіки. 2015. №5. С. 863-866.

3. Гуржій С. Г., Копиленко О. Л, Янушевич Я. В. Боротьба 3 відмиванням коштів: правовий, організаційний та практичний аспекти : монографія. Київ : Парлам. вид-во, 2005. 216 с.

4. Money laundering through the securities markets. EAG Typology Report. URL : https://eurasiangroup.org/files/Typologii\%20EAG/WGTYP_ 2013_4_eng_copy0.pdf.

5. Василишин В. О., Леонов Б. Д. Міжнародне співробітництво у сфері боротьби з тероризмом. Державна політика у сфері протидіi тероризму: міжнародний досвід $і$ його актуальність для України : матеріали Інтернет-конференції. 2015. URL : http://www.ap.gp.gov.ua/ userfiles/file/Academia2016/sb_conf/konferens-25-06-2015.pdf.

6. Khalin O. Need for legislative Changts in the Mechanism of Ensuring the Effectiveness of the Investigation of Legalization of Proceeds from Crime. Віче. 2016. №5-6 (409-410). P. 44-46.

7. Варналій 3. С., Гончарук А. Я., Жаліло Я. А. Тіньова економіка: сутність, особливості та шляхи легалізації : навч. посібник. Київ : Нац. ін-т стратегічних досліджень, 2006. 575 с.

8. Коломієць I. В. Державний фінансовий моніторинг в Україні : сучасний стан і шляхи вдосконалення. Форум права. 2010. №11. С. $164-169$.

9. Корженівський Я. В. Методи легалізації (відмивання) доходів, одержаних злочинним шляхом. Науковий вісник Національного університету державної податкової служби Украӥни (економіка, право). 2011. №1(52). С. 289-295.

10. Egmont Group, 1995, The First International Meeting of Organizations Devoted to Anti-Money Laundering (Brussels). URL: http://www.golovan.com.ua/fileadmin/Blog/CASE_OF_GOLOVAN_v_U KRAINE.ukr.pdf.

11. Волковинська T. Співробітництво 3 FATF як фактор формування в Україні європейської моделі фінансової системи. URL : http://www.nbuv.gov.ua/portal/soc_gum/Un_msm/2007_12/Volkov.pdf.

12. Global Financial Integrity works to curtail illicit financial flows by producing groundbreaking research, promoting pragmatic policy solutions, and advising governments.URL: http://www.gfintegrity.org/.

13. Козак Ю. Г., Логвінова Н. С., Ковалевський В. В. Міжнародні фінанси : навчальний посібник. Видання 3-тє, перероб. та доп. Київ : Центр учбовової літератури, 2007. 640 с. 
14. Петрук О. М., Смагло О. В. Зарубіжний досвід організації фінансового моніторингу та перспективи його впровадження в Україні. WSPÓŁPRACA EUROPEJSKA NR. 2015. №2. C. 89-99.

15. Буткевич С. А. Досвід США щодо запобігання та протидії легалізації доходів, одержаних злочинним шляхом. Вчені записки Тавричного університету В.І. Вернадського. 2008. Т. 21 (60). №1. С. 68-74.

16. Куришко О. О. Аналіз світового досвіду у сфері протидії легалізації доходів, отриманих злочинним шляхом, у контексті можливості його використання в Україні. Фінансовий простір. 2013. №2 (10). С. 8-15.

17. Міжнародні стандарти 3 протидії відмиванню доходів та фінансуванню тероризму і розповсюдженню зброї масового знищення. Рекомендації FATF. URL : http://www.sdfm.gov.ua/content/file/ site_docs/ 2012/22.03.2012/1.pdf.

18. International Standards on Combating Money Laundering and the Financing of Terrorism \& Proliferation the FATF Recommendations (The FATF Recommendations). URL : http://000.fatfgafi.org/topics/ fatfrecommendations/documents/fatfrecommendations2012.html.

19. Іваницька О. М. Державне регулювання розвитку фінансової інфраструктури: монографія. Київ : НАДУ, 2005. 276 с.

20. Росоляк О. Фінансовий моніторинг: історія розвитку та досвід запровадження в Україні. Фінансове право. 2005. №11. С. 30-32.

21. Васенко В. К., Челядіна О. С. Боротьба 3 легалізацією (відмиванням) незаконно отриманих грошей. Безпека і право. 2012. URL : http://pb.univd.edu.ua.

22. Коваль Я. С. Державний інструментарій ідентифікації ризиків, як елемент попередження негативного впливу на економічний стан банківської системи. Вчені записки Університету «КРОК». 2019. №1(53). C. 65-74. DOI: https://doi.org/10.31732/2663-2209-2019-53-65-74.

23. Омельченко І. Легалізація брудних грошей. Юридичний журнал. 2010. №3. URL : http://www.justinian.com.ua/article.php?id=3456.

24. Сгоричева С. Б. Стадії та інструменти легалізації доходів, одержаних злочинним шляхом. Організація фінансового моніторингу в банках : навчальний посібник. Київ : Центр учбової літератури, 2014. 292 c. URL : http://pidruchniki.com/68436/bankivska_sprava/stadiyi_ instrumenti_legalizatsiyi_dohodiv_oderzhanih_zlochinnim_shlyahom.

25. Росоляк О. Фінансовий моніторинг: історія розвитку та досвід запровадження в Україні. Фінансове право. 2005. №11. С. 30-32.

26. Соловій Я. І., Дудка В. В., Дудка А. В. Легалізація (відмивання) доходів, одержаних злочинним шляхом : монографія. Івано-Франківськ : Наддвірнянська друкарня, 2008. 231 с.

27. Савченко О. Становлення та розвиток системи фінансового моніторингу в банках України. URL : https://kneu.edu.ua/userfiles/ Credit_Economics_Department/KMBD/konkurs/Konkyrs2016/Savchenko_ 
Oksana_Stanovlennya_ta_rozvitok_sistemi_fD196nansovogo_monD196to ringu_v_bankah_UkraD197ni_.pdf.

28. Про запобігання та протидію легалізації (відмиванню) доходів, одержаних злочинним шляхом, фінансуванню тероризму та фінансуванню розповсюдження зброї масового знищення: Закон України від 28.04.2020 p. №361-IX. URL : https://zakon.rada.gov.ua/laws/show/361-20\#Text.

29. Коваль Я. С., Мігус І. П., Андрієнко В. М. Міжнародний досвід формування державної політики у сфері забезпечення фінансової безпеки як складової національної безпеки. Демократичне врядування. Львів, 2017. Вип. 20. URL : http://www.lvivacademy.com/vidavnitstvo_1/ visnyk20/index.html.

30. Thony J. F. Processing Financial Information in Money Laundering Matters, The Financial Intelligence Units. European Journal of crime, Criminal Law and Criminal Justice. 1996. p. 3.

31. Розенфельд Н. А. Заходи підвищення ефективності кримінальноправового забезпечення протидії фінансуванню тероризму та легалізації доходів, здобутих злочинним шляхом. Актуальні питання вдосконалення начіонального законодавства України у сфері запобігання та протидіі легалізації доходів, одержаних злочинним шляхом, $i$ фінансування тероризму : збірник матеріалів конференції за підтримки Програми Європейського Союзу ТАСІС Проекту з питань боротьби з відмиванням коштів та фінансуванням тероризму в Україні (MOLI-UA-2), 18 грудня 2008 р., м. Київ. Київ, 2008. С. 52-70.

32. Шкурко В. I. Історія становлення та розвитку правового регулювання співробітництва держав-членів СС з протидії легалізації доходів, отриманих злочинним шляхом. Міжнародне право. 2019. №145. C. 256-267. DOI: 10.21564/2414-990x.145.163662.

33. Холдер Э. Механизмы и процедуры возвращения активов в США : практическое руководство для международного сотрудничества. Вашингтон : Государственный департамент США, Министерство юстиции США, отдел уголовных дел, отделение конфискации активов и борьбы с легализацией незаконных доходов, A/GIS/GPS, 2012. 21 с.

34. Olson M. and Zinnes C. The Shadow Economy: Friend or Foe? World Development. 2002. 56 p.

35. Бисага К. В. Нормативно-правове регулювання в Свропейському Союзі протидії відмиванню доходів, одержаних злочинним шляхом, фінансуванню тероризму та розповсюдженню зброї масового знищення (наднаціональний рівень). Вісник НАДУ при Президентові України. Серія «Державне управління». 2016. №3. С. 35-42.

36. Москаленко Н. В. Фінансовий моніторинг як інструмент економічної безпеки. Науковий вісник Львівського державного університету внутрішніх справ. 2009. №1. С. 1-7. 


\title{
АНАЛІЗ ЕКОНОМІКИ ПІДПРИЕМСТВА У СТАНІ НЕВИЗНАЧЕНОСТІ: ОСОБЛИВОСТІ ІНСТРУМЕНТАРІЮ ДОСЛІДЖЕННЯ
}

\author{
Ананьєва Олеся Олександрівна, \\ кандидат економічних наук, дочент, \\ ВН3 «Університет економіки та права «КРОК», \\ ORCID: https://orcid.org/0000-0002-9544-7408, \\ Гофман Мирослава Олександрівна, \\ кандидат економічних наук, дочент, \\ ВНЗ «Університет економіки та права «КРОК», \\ ORCID: https://orcid.org/0000-0002-3977-7584
}

Aнотація. Сучасні умови нестабільності економіки визначають особливі вимоги до забезпечення більшої економічної стійкості підприємств. Перший крок на цьому шляху - адекватний аналіз впливу економічної невизначеності на діяльність підприємств. Наука економічного аналізу має в своєму арсеналі сукупність традиційних та новітніх прийомів аналізу. Всі вони важливі для обгрунтування підприємницьких рішень. Але існуючі методики аналізу повинні постійно адаптуватися до нових економічних умов, включно з тими, що пов'язані з розширенням меж економічної невизначеності. Цей підрозділ монографії присвячено саме такій адаптації до потреб урахування в аналізі обставин невизначеності у діяльності підприємств.

Ключові слова: аналіз ефективності, збалансованість системи показників, експертний метод, статистичні методи економічного аналізу.

Проблема дослідження ризиків у діяльності підприємства, породжених економічною невизначеністю, перебуває у центрі уваги дослідників різних країн. Найбільш цитованими у цій царині є роботи Ф. Найта [1], Дж. Кальман [2], М. Круї, Д. Галай, Р. Марк [3], Т. Флін, М. Маккарті [4]. Досліджуючи невизначеність у діяльності підприємств, автори згаданих робіт роблять акценти на таких проблемах: трактування змісту та кількісного оцінювання ризиків, управління ризиками, контроль втрат проєктів, класифікація ризиків, метод передбачення ризиків.

Проблемі ідентифікації та оцінювання ризиків в українській економіці присвячено роботи багатьох українських дослідників. Особливе місце у цих дослідженнях належить українському науковцю та практику 3 української діаспори М. Паславському [5]. Згаданий дослідник дивився на ризики українського бізнесу з позицій глибокого знання української дійсності, поєднаного з розумінням загальних законів ведення бізнесу в розвинених країнах. 
Попри те, що на даний момент існує значна кількість наукових праць у галузі аналізу невизначеності (ризиків) у економічній діяльності підприємств, проблема адекватного (відповідного потребам) аналізу залишається актуальною.

Класифікуючи інструменти аналізу невизначеності, ми виокремлюємо, за різними класифікаційними ознаками, такі групи інструментів (рис. 1). Такими класифікаційними ознаками можуть бути: 1) частота (поширеність) використовуваних інструментів, що зазвичай пов'язано зі складністю їх застосування й тлумачення результатів: традиційні та новітні; 2) мета застосування інструментів аналізу невизначеності: для оцінювання внутрішніх та зовнішніх чинників впливу; 3) спрямованість аналізу, яка може орієнтуватися на оцінювання або майбутніх подій, або минулого: Ex post та Ex ante.

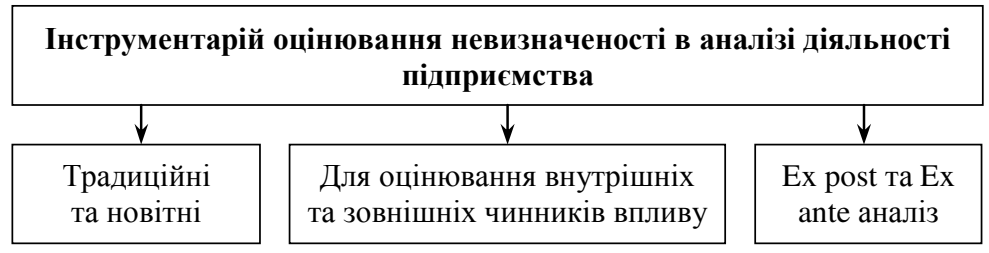

Рис. 1. Класифікація інструментів оцінювання невизначеності у діяльності підприємства

Джерело: складено авторами самостійно.

В оцінюванні невизначеності у діяльності підприємства, на наш погляд, найбільшої уваги потребує з'ясування особливостей традиційних та новітніх інструментів. Адже традиційні інструменти дають обмежену відповідь на питання, яким був або яким є вплив невизначеності. Натомість, новітні інструменти забезпечують більш глибокий аналіз невизначеності, але потребують більших за обсягом баз даних та складнішого інструментарію. Тому ми припускаємо, що традиційні й новітні інструменти мають використовуватися одночасно.

До традиційних інструментів оцінювання невизначеності, на наш погляд, належить іiі оцінювання через зміни у показниках ефективності підприємства, продуктивності праці тощо. Настання стрімких і непередбачуваних змін цих показників може інтерпретуватися як прояв невизначеності.

Категорія «ефективність» є багатогранною і має тривалу історію використання в науковому обігу. Майже в кожній науковій школі, починаючи з XVIII ст., намагалися дати іiі визначення. Вважається, що першими, хто спробували розкрити ії сутність, були В. Петті та Ф. Кене. Але вони розглядали ефективність як результативність і застосовували іï для оцінки окремих урядових чи приватних заходів [6]. Відносної 
самостійності ця категорія набула в роботах Д. Рікардо, який розглядав іiі як «відношення отриманого результату до певного виду витрат». Він здійснив спробу оцінити ефективність капіталу [7]. За уявленнями К. Маркса, виробництво $є$ ефективним, якщо при мінімальному авансованому капіталі створювати максимальну кількість продукту 3 можливими меншими витратами сил і засобів [8]. Представники неокласичної школи економіки XX ст. визначали ефективність як співвідношення результатів і витрат.

У всесвітньо відомому підручнику з економіки К. Макконел та С. Брю подано таке пояснення економічної ефективності: «Більша кількість продукту, отриманого від даного обсягу витрат, означає підвищення ефективності» [9].

Американський економіст $X$. Лібенштайн увів до наукового обігу поняття X-ефективність в економіці. Підприємство вважають $\mathrm{X}$-ефективним, якщо воно виробляє (реалізує) за наявних ресурсів $\mathrm{i}$ найкращою 3 доступних технологій максимально можливий обсяг продукції [10].

Дуже часто ефективність розглядають як результативність. У західних тлумачних словниках є смислова відмінність між поняттями ефективність та результативність. Зокрема, «еfficiency» перекладається 3 англійської як ефективність і означає - продуктивність, корисна робота [11]. Натомість, «Effectiveness», у перекладі 3 англійської, означає ступінь успішності, що дає бажаний результат [12]. Пітер Друкер також акцентував на цій відмінності понять, а саме «результативність» (effectiveness) означає «робити правильні речі» (doing the right things), a «ефективність» (efficiency) - «робити речі правильно» (doing thing sright). Він зазначає, що «для того, щоб бути успішною протягом тривалого часу, щоб вижити та досягнути своїх цілей, організація повинна бути як ефективною, так і результативною» [13].

Розмежування понять (явищ) «ефективність» та «результативність» затверджено в ДСТУ ISO 9000:2007 «Системи управління якістю: основні положення та словник термінів». Відповідно до даного стандарту ефективність (efficiency) - це співвідношення між досягнутим результатом і використаними ресурсами, а результативність (effectiveness) - це ступінь реалізації запланованої діяльності та досягнення запланованих результатів [14].

На нашу думку, ефективність діяльності підприємства - це його здатність досягати поставленої мети за умови наближення до оптимального співвідношення між отриманими результатами та затраченими на їх досягнення ресурсами.

3 огляду на таке наше уявлення про зміст поняття «ефективність діяльності підприємства» економічна невизначеність може подаватися як феномен, що може виявлятися у такому: 
- недосягненні визначеної мети або суттєвих відхиленнях від неї;

- зменшенні обсягів матеріальних та фінансових результатів діяльності підприємства;

- зростанні матеріальних та фінансових витрат на досягнення однакових, за інших рівних умов, тобто співставних, результатів.

При оцінюванні ефективності діяльності підприємства потрібно також враховувати різні підходи до визначення витрат, які можуть використовуватися при розрахунку ефективності:

1) ресурсний: результат порівнюється з ресурсами;

2) витратний: результат порівнюється з поточними витратами;

3) ресурсно-витратний: поєднання двох попередніх підходів.

Аналіз ефективності діяльності підприємства доцільно здійснювати за трьома групами показників: продуктивності, ефективності додаткових вкладень у капітал та рентабельності.

Показники продуктивності характеризують продуктивність ресурсів підприємства і показують, скільки гривень валової продукції припадає на одиницю (одну гривню вартості) ресурсів підприємства. Розраховується як відношення виробленої продукції до вартості окремих ресурсів.

У розвинених країнах продуктивність є предметом статистичних досліджень. У зарубіжній практиці найбільш поширеним показником продуктивності є показник продуктивності праці. Різниця лише в тому, що у країнах Східної Європи цей показник розраховують за випуском, а в західноєвропейських країнах, США та Австралії для розрахунку продуктивності праці використовують додану вартість. Показники продуктивності капіталу відносяться до показників національної статистики США і Австралії. Національна статистика зарубіжних країн розраховує та публікує показники як однофакторної, так i багатофакторної продуктивності. Багатофакторна продуктивність праці й капіталу (за випуском і доданою вартістю) широко розраховується в більшості країн з ринковою економікою. І лише в Канаді та США визначаються показники продуктивності всієї сукупності ресурсів (праці, основного й оборотного капіталу) [15].

Друга група показників - ефективності додаткових вкладень у капітал - використовується для визначення економічної доцільності додаткового нарощення капіталу. Відповідні показники розраховуються за формулою [16]:

$$
\text { Kef }=\frac{\operatorname{Prod}_{1}-\operatorname{Prod}_{0}}{C_{1}-C_{0}},
$$

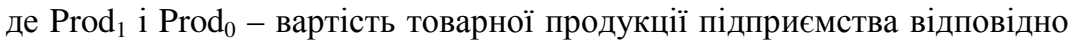
у звітному і базовому періодах; $C_{1}$ i $C_{0}$ - середньорічна вартість капіталу відповідно у звітному і базовому періодах. 
При розрахунку ефективності додаткового залучення джерел формування капіталу та додаткових вкладень в основний і оборотний капітал змінюється знаменник формули з урахуванням цих складових капіталу.

Слід зазначити, що економічна природа даного показника $\epsilon$ складною. При розрахунку цього показника можуть бути одержані чотири варіанти результатів:

$$
\begin{aligned}
& \text { 1. Kef }=\frac{\operatorname{Prod}_{1}-\operatorname{Prod}_{0}}{C_{1}-C_{0}}=\frac{\Delta \text { Prod }}{\Delta C}, \\
& \text { 2. Kef }=\frac{\operatorname{Prod}_{1}-\operatorname{Prod}_{0}}{C_{1}-C_{0}}=\frac{-\Delta \text { Prod }}{\Delta C}, \\
& \text { 3. Kef }=\frac{\operatorname{Prod}_{1}-\operatorname{Prod}_{0}}{C_{1}-C_{0}}=\frac{\Delta \text { Prod }}{-\Delta C}, \\
& \text { 4. Kef }=\frac{\operatorname{Prod}_{1}-\operatorname{Prod}_{0}}{C_{1}-C_{0}}=\frac{-\Delta \text { Prod }}{-\Delta C} \text {. }
\end{aligned}
$$

Перший варіант показує, що із зростанням розміру капіталу підприємства зростає і товарна продукція. За таких умов важливо, щоб даний показник мав значення більше одиниці, що свідчитиме про високу ефективність додаткових вкладень у капітал. У другому варіанті результат буде зі знаком мінус, оскільки зростання капіталу супроводжується зменшенням товарної продукції, що характеризує неефективні додаткові вкладання коштів у капітал. При цьому важливо мінімізувати негативні наслідки, тому значення даного показника має наближатися до 0. Третій варіант відображає ситуацію, коли приріст продукції одержують при зменшенні величини капіталу. Результат також буде зі знаком мінус. Зростання значення даного показника за модулем свідчить про підвищення ефективності використання капіталу. При цьому потрібно пам'ятати, що такий варіант не $є$ прийнятним для підприємств, які мають недостатню забезпеченість капіталом. I останній, четвертий, варіант одержують за умови, коли зменшення розміру капіталу призводить до зменшення товарної продукції. Найменш несприятливою ситуацією $є$ така, коли результат був меншим одиниці, оскільки за таких умов товарна продукція зменшується не так істотно, як капітал підприємства.

Важливе значення для аналізу підприємства мають показники рентабельності. Вони відображають рівень прибутковості підприємства, а також можливості формування засобів для здійснення поточної діяльності підприємства.

На рис. 2. представлено основні показники аналізу економіки підприємства за кожною із трьох розглянутих груп. 


\begin{tabular}{|c|c|c|}
\hline \multicolumn{3}{|c|}{ Показники аналізу економіки підприсмства } \\
\hline$\downarrow$ & $\downarrow$ & $\downarrow$ \\
\hline $\begin{array}{c}\text { Показники } \\
\text { продуктивності } \\
\text { - продуктивність праці; } \\
\text { - продуктивність } \\
\text { капіталу; } \\
\text { - фондовіддача; } \\
\text { - продуктивність } \\
\text { оборотного капіталу; } \\
\text { - продуктивність } \\
\text { власного капіталу; } \\
\text { - продуктивність } \\
\text { позичкового капіталу. }\end{array}$ & $\begin{array}{c}\text { Показники } \\
\text { ефективності } \\
\text { додаткових вкладень у } \\
\text { капітал } \\
\text { - ефективність додаткових } \\
\text { вкладень у капітал; } \\
\text { - ефективність додаткових } \\
\text { вкладень в основний } \\
\text { капітал; } \\
\text { - ефективність додаткових } \\
\text { вкладень в оборотний } \\
\text { капітал. }\end{array}$ & $\begin{array}{c}\text { Показники } \\
\text { рентабельності } \\
\text { - рентабельність продукції; } \\
\text { - рентабельність продажу; } \\
\text { - рентабельність капіталу; } \\
\text { - рентабельність основного } \\
\text { капіталу; } \\
\text { - рентабельність оборотного } \\
\text { капіталу; } \\
\text { - рентабельність власного } \\
\text { капіталу. }\end{array}$ \\
\hline
\end{tabular}

\section{Рис. 2 Основні показники аналізу економіки підприємства} Джерело: складено авторами самостійно.

Для поглибленого аналізу ефективності використання капіталу застосовують багатофакторну модель, що була розроблена фірмою «Дюпон» у 20-х роках минулого століття. Вона передбачає розкладання рентабельності капіталу на окремі показники, пов'язані в єдиній системі. Кожен з факторів $є$ змістовним фінансовим показником. Такий аналіз дає можливість визначити індивідуальний вплив кожного фактору на результати господарювання, своєчасно виявляти й усувати їх негативну дію. Крім того, завдяки відповідним розрахункам оцінюють невикористані внутрішні резерви щодо підвищення ефективності діяльності підприємств. Рентабельність капіталу (ROC) за даною моделлю визначається такою формулою [17]:

$$
\begin{aligned}
& R O C=R O S \times K O C, \\
& \frac{P}{C}=\frac{P}{S A L} \times \frac{S A L}{C},
\end{aligned}
$$

де $R O S$ - рентабельність продажу; Кос - коєфіцієнт обороту капіталу; $P$ - операційний прибуток підприємства; $S A L$ - виручка від реалізації продукції.

Згадана модель показує вплив на рентабельність капіталу рентабельності продажу та коєфіцієнту обороту капіталу. Аналізуючи показники, можна визначити резерви подальшого підвищення ефективності використання капіталу. Причинами зниження рентабельності капіталу можуть бути як зниження рентабельності продажу, так і уповільнення обороту капіталу. Якщо на зниження показника рентабельності більшою мірою впливає перший фактор, то необхідно більше уваги приділяти маркетингу, ціновій та асортиментній політиці. Зростання даного 
показника може відбуватися під впливом як внутрішніх, так і зовнішніх факторів, на які підприємство не може впливати. Тому, аналізуючи показник, необхідно враховувати вплив усіх можливих факторів. Прискорення обороту капіталу можна досягти шляхом зменшення основного чи оборотного капіталу. Тоді увагу необхідно зосереджувати на продажу чи списанні основних засобів, що не використовуються чи неефективно використовуються; зменшенні запасів сировини, матеріалів, незавершеного виробництва, готової продукції; зменшенні дебіторської заборгованості.

Згадана модель $є$ спрощеною, але їі можна переформувати у багатофакторну модель, яка дасть змогу повною мірою визначити вплив окремих факторів на ефективність використання капіталу підприємств. Багатофакторну модель ефективності використання капіталу можна, на наш погляд, представити таким чином [18]:

$$
\begin{aligned}
& R O C=R O S \times C P \times K r \times K d \times K f l \times K e, \\
& \frac{P}{C}=\frac{P}{S A L} \times \frac{S A L}{F C} \times \frac{F C}{W C} \times \frac{W C}{D} \times \frac{D}{E} \times \frac{E}{C},
\end{aligned}
$$

де $R O C$ - рентабельність капіталу; $P$ - операційний прибуток підприємства, тис. грн; $C$ - вартість усього капіталу, тис. грн; $S A L$ - виручка від реалізації продукції, тис. грн; $F C$ - вартість основного капіталу, тис. грн; $W C$ - вартість оборотного капіталу, тис. грн; $D$ - позичковий капітал, тис. грн; $E$ - власний капітал, тис. грн.

Відповідно до запропонованої моделі, на рентабельність капіталу впливають такі фактори: рентабельність продажу $(R O S)$, продуктивність основного капіталу $(P C)$, коєфіцієнт співвідношення основного й оборотного капіталу $(\mathrm{Kr})$, коєфіцієнт покриття позичкового капіталу оборотним $(K d)$, коєфіцієнт фінансового лівериджу $(K f l)$, коєфіцієнт автономії $(K e)$.

Для визначення впливу окремих факторів на рентабельність капіталу пропонуємо такий алгоритм обчислень, що базується на використанні індексного (Ir) методу дослідження:

$$
\begin{aligned}
& I r=\frac{R O S_{1} \times P C_{1} \times K r_{1} \times K d_{1} \times K f l_{1} \times K e_{1}}{R O S_{0} \times P C_{0} \times K r_{0} \times K d_{0} \times K f l_{0} \times K e_{0}}=\frac{R O S_{1} \times P C_{0} \times K r_{0} \times K d_{0} \times K f l_{0} \times K e_{0}}{R O S_{0} \times P C_{0} \times K r_{0} \times K d_{0} \times K l_{0} \times K e_{0}} \times \\
& \times \frac{R O S_{1} \times P C_{1} \times K r_{0} \times K d_{0} \times K f l_{0} \times K e_{0}}{R O S_{1} \times P C_{0} \times K r_{0} \times K d_{0} \times K f l_{0} \times K e_{0}} \times \frac{R O S_{1} \times P C_{1} \times K r_{1} \times K d_{0} \times K f l_{0} \times K e_{0}}{R O S_{1} \times P C_{1} \times K r_{0} \times K d_{0} \times K l_{0} \times K e_{0}} \times \\
& \times \frac{R O S_{1} \times P C_{1} \times K r_{1} \times K d_{1} \times K f l_{0} \times K e_{0}}{R O S_{1} \times P C_{1} \times K r_{1} \times K d_{0} \times K l_{0} \times K e_{0}} \times \frac{R O S_{1} \times P C_{1} \times K r_{1} \times K d_{1} \times K l_{1} \times K e_{0}}{R O S \times P C_{1} \times K r_{1} \times K d_{1} \times K f l_{0} \times K e_{0}} \times \\
& \times \frac{R O S_{1} \times P C_{1} \times K r_{1} \times K d_{1} \times K f l_{1} \times K e_{1}}{R O S_{1} \times P C_{1} \times K r_{1} \times K d_{1} \times K f l_{1} \times K e_{0}} .
\end{aligned}
$$


Перший частковий індекс відображає вплив рентабельності продажу на рентабельність капіталу, другий - продуктивності основного капіталу, третій - коєфіцієнта співвідношення між основним і оборотним капіталом, четвертий - коєфіцієнта покриття позичкового капіталу оборотним, п’ятий - коєфіцієнта фінансового лівериджу, шостий коєфіцієнта автономії.

За моделлю Дюпон також можна визначати вплив окремих факторів на рентабельність власного капіталу [19]:

$$
\begin{aligned}
& R O E=R O S \times K o c \times K d ; \\
& \frac{N P}{E}=\frac{N P}{S A L} \times \frac{S A L}{C} \times \frac{C}{E} ;
\end{aligned}
$$

де $R O E$ - рентабельність власного капіталу; $K d$ - коєфіцієнт боргового навантаження; $N p$ - чистий прибуток підприємства.

На рентабельність власного капіталу, за цією моделлю, впливає три фактори: рентабельність продажу $(R O S)$; коєфіцієнт обороту капіталу $(K o c)$; коєфіцієнт боргового навантаження $(K d)$. Специфіку впливу перших двох факторів розглянуто при аналізі рентабельності всього капіталу підприємства. Коєфіцієнт боргового навантаження відображає обрану підприємством фінансову структуру капіталу. Його зростання, з одного боку, може підвищувати рентабельність власного капіталу, а з іншого збільшувати ризик банкрутства підприємства.

Зростання невизначеності зазвичай пов'язується 3 погіршенням ситуації у провідних галузях національних економік. Українська економіка була й ще залишається індустріально-аграрною. Тому динаміка промислового виробництва у ній $є$ вирішальним маркером змін. Для кожного окремого українського підприємства динаміка промислового виробництва може розглядатися як зовнішній чинник визначеності або, навпаки, невизначеності стану. Поточний стан української промисловості не відповідає вимогам, що диктуються умовами глобальних змін. Промислове виробництво перестало бути основним чинником зростання національної економіки.

Падіння промислового виробництва загалом, а особливо виробництва інвестиційної продукції, спричинює негативні наслідки відставання і послаблення національної економіки, втрату конкурентних позицій України на світових ринках. Непоправних втрат зазнала Україна та її промисловий потенціал унаслідок воєнної агресії східного сусіда, окупації й анексії промислово інтенсивних регіонів Донбасу та Криму, розграбування майна підприємств, згортання виробництва на непідконтрольних українській владі й прилеглих до них територіях. Ведення торговельної війни проти українського експорту призвело до руйнування промислових потужностей, розриву традиційних внутрішніх 
і зовнішніх господарських зв'язків, обвального скорочення масштабів виробництва.

Розширення зв'язків $з$ європейськими партнерами чинить вагомий позитивний вплив на розвиток промислового потенціалу країни. Цьому сприяє дія Угоди про асоціацію між Україною та СС, особливо, існування зони вільної торгівлі. Українські експортери частково компенсували втрату ринків колишнього партнера завдяки активізації торговельних відносин з СС, який став для України основним торговим партнером $\mathrm{i}$ ключовим іноземним інвестором [20].

Показники аналізу економіки підприємств за кожною із трьох запропонованих нами груп на основі даних промислових підприємств України подано в табл. 1.

Табличя 1

Основні показники продуктивності промислових підприємств України за 2013 - 2018 рр.

\begin{tabular}{|l|c|c|c|c|c|c|c|}
\hline $\begin{array}{c}\text { Показники } \\
\text { продуктивності }\end{array}$ & $\mathbf{2 0 1 3}$ р. & $\mathbf{2 0 1 4}$ p. & $\mathbf{2 0 1 5}$ р. & $\mathbf{2 0 1 6}$ p. & $\mathbf{2 0 1 7}$ p. & $\mathbf{2 0 1 8}$ р. & $\begin{array}{c}\text { Відносне } \\
\text { відхилення } \\
\mathbf{2 0 1 8} \text { р. до } \\
\mathbf{2 0 1 3} \text { р. . \% }\end{array}$ \\
\hline $\begin{array}{l}\text { Продуктивність } \\
\text { праці, тис. грн /особу }\end{array}$ & 418,64 & 532,19 & 694,05 & 851,74 & 1097,38 & 1255,76 & 299,96 \\
\hline $\begin{array}{l}\text { Продуктивність } \\
\text { капіталу }\end{array}$ & 0,70 & 0,69 & 0,73 & 0,75 & 0,84 & 0,91 & 129,87 \\
\hline Фондовіддача & 0,75 & 0,72 & 0,56 & 0,56 & 0,89 & 0,98 & 129,57 \\
\hline $\begin{array}{l}\text { Продуктивність } \\
\text { оборотного капіталу }\end{array}$ & 1,56 & 1,51 & 1,51 & 1,44 & 1,51 & 1,67 & 107,53 \\
\hline $\begin{array}{l}\text { Продуктивність } \\
\text { власного капіталу }\end{array}$ & 1,80 & 2,05 & 3,04 & 3,82 & 4,57 & 4,17 & 231,36 \\
\hline $\begin{array}{l}\text { Продуктивність } \\
\text { позичкового капіталу }\end{array}$ & 1,14 & 1,04 & 0,96 & 0,93 & 1,02 & 1,16 & 101,64 \\
\hline
\end{tabular}

Джерело: розраховано авторами за даними Державної служби статистики України.

Аналізуючи дані табл. 1, можна констатувати, що за період 2013 2018 рр. показник продуктивності праці на промислових підприємствах в Україні має стійку тенденцію до зростання. Середній річний приріст показника складає 167,4 тис. грн на одного зайнятого. У 2018 р. цей показник збільшився у майже 3 рази порівняно з 2013 р. Проте варто зазначити, що Україна за показником продуктивності праці в промисловості відстає від західноєвропейських країн. Основними причинами низької продуктивності праці є:

- зношені і застарілі основні фонди;

- застарілі технології;

- недостатньо ефективна організація операційних систем та виробничих процесів;

- неефективна організація праці; 
- низькоефективний менеджмент;

- практична відсутність стимулів до побудови інноваційного виробництва, пов' язана з високим рівнем монополізації;

- слабка інвестиційна інфраструктура;

- недостатня інформатизація та автоматизація виробництва.

Показник продуктивності капіталу виявляє ефективність використання капіталу і має тенденцію до зростання протягом 2013 2018 рр., що є позитивним. Проте, дані табл. 1 свідчать про низький рівень продуктивності капіталу. Так, на кожну гривню, вкладену у виробництво продукції у 2013 р., було отримано всього 70 коп. виробленої продукції, в 2017 р. - 84 коп., а в 2018 р. - 91 коп.

Позитивним для промислових підприємств України є збільшення показника фондовіддачі в динаміці. Як видно 3 табл. 1, показник фондовіддачі зменшився в 2015 р. в порівнянні з 2014 р. на 22,22\%. На рівень фондовіддачі впливають різні фактори, такі як зміна обсягу продукції, ефективність використання основних засобів. Зростання даного показника спостерігається в 2017 р. й становить 0,89. У 2018 р. він збільшився відносно 2013 р. на 29,57\%.

Коєфіцієнт продуктивності оборотного капіталу характеризує ефективність використання оборотного капіталу підприємства. Від якості управління оборотним капіталом залежить безперервність процесу виробництва та реалізації продукції, а як наслідок, - його платоспроможність та рентабельність. Ефективність використання оборотного капіталу полягає в тому, щоб на кожну одиницю оборотного капіталу досягати максимум збільшення виробництва. Для досліджуваного періоду прослідковується тенденція незначної зміни даного показника. Так, показник продуктивності оборотного капіталу в 2018 р. збільшився лише на 7, 53\% відносно 2013 р.

Щодо показника продуктивності власного капіталу, то тут спостерігається тенденція до його зростання протягом досліджуваного періоду, що є позитивним для промислових підприємств. Так, продуктивність власного капіталу в 2018 р. зросла в 2,31 рази, на відміну від 2013 р. Досягнути таких результатів вдалося за рахунок збільшення обсягів виготовленої продукції.

Залучення позикових коштів до обороту підприємства $є$ нормальним явищем. За рахунок такого залучення підприємство покращує свій фінансовий стан, щоправда, за умови своєчасного повернення боргів. Показник продуктивності позичкового капіталу демонструє ефективність використання позичкового капіталу. Дані таблиці свідчать про зменшення даного показника протягом 2014 - 2016 pp., і лише в 2017 р. він збільшився порівняно з 2016 р. на 9,68\%. Можна зробити висновок про неефективне використання позичкового капіталу. 
Загалом усі аналізовані показники зростають, що $є$ досить позитивним для промисловості. Для детальнішого аналізу перейдемо до показників ефективності додаткових вкладень у капітал (табл. 2).

Табличя 2

\section{Показники ефективності додаткових вкладень у капітал} промислових підприсмств України за 2014 - 2018 рр.

\begin{tabular}{|l|c|c|c|c|c|}
\hline \multicolumn{1}{|c|}{$\begin{array}{c}\text { Показники ефективності } \\
\text { додаткових вкладень у капітал }\end{array}$} & $\mathbf{2 0 1 4}$ p. & $\mathbf{2 0 1 5}$ p. & $\mathbf{2 0 1 6}$ p. & $\mathbf{2 0 1 7}$ p. & $\mathbf{2 0 1 8}$ p. \\
\hline $\begin{array}{l}\text { Ефективність додаткових вкладень у } \\
\text { капітал }\end{array}$ & 0,547 & 1,047 & 0,841 & 1,445 & 2,463 \\
\hline $\begin{array}{l}\text { Ефективність додаткових вкладень в } \\
\text { основний капітал }\end{array}$ & 0,419 & 0,260 & 0,553 & $-0,781$ & 3,375 \\
\hline $\begin{array}{l}\text { Ефективність додаткових вкладень в } \\
\text { оборотний капітал }\end{array}$ & 0,964 & 1,501 & 1,160 & 1,870 & 7,432 \\
\hline $\begin{array}{l}\text { Ефективність додаткових вкладень у } \\
\text { власний капітал }\end{array}$ & $-1,384$ & $-2,250$ & $-11,999$ & 15,397 & 2,539 \\
\hline $\begin{array}{l}\text { Ефективність додаткових вкладень у } \\
\text { позичковий капітал }\end{array}$ & 0,392 & 0,714 & 0,786 & 1,594 & 82,279 \\
\hline
\end{tabular}

Джерело: розраховано авторами за даними Державної служби статистики Украӥни.

Показник ефективності додаткових вкладень у капітал показує, що із збільшенням розміру капіталу підприємств промисловості у 2017 2018 рр. зріс і обсяг виробленої продукції. Проте, аналіз даних табл. 2 демонструє низьку ефективність додаткових вкладень коштів у капітал у 2014 та 2016 рр., оскільки темпи зростання обсягів виробництва продукції були нижчими за темпи зростання вартості капіталу.

Негативна тенденція спостерігається щодо показника ефективності додаткових вкладень в основний капітал. Так, значення даного показника знаходиться на рівні менше одиниці, що свідчить про високу неефективність додаткових вкладень в основний капітал. I лише в 2018 році спостерігається результат ефективності таких додаткових вкладів.

Коєфіцієнти ефективності додаткових вкладень у власний капітал мали від'ємне значення в 2014 - 2016 рр., що характеризує неефективні додаткові вкладення коштів у власний капітал. Цей показник відображає ситуацію, коли приріст виробленої продукції було отримано за рахунок зменшення власного капіталу. Результати даного показника за модулем зростають, а починаючи з 2017 р., зростає його абсолютне значення. Але варто пам'ятати про забезпеченість підприємства капіталом.

Аналізуючи показник ефективності додаткових вкладень у позичковий капітал, прослідковується тенденція до зростання показника. Це свідчить про зростання розміру позичкового капіталу та обсягу виробленої продукції. Висока ефективність додаткових залучень позичкового капіталу спостерігається у 2018 році. 
Третя група показників оцінювання ефективності діяльності підприємств промисловості подана в табл. 3.

Таблиия 3

Оцінка показників рентабельності промислових підприємств України за 2013 - 2018 рр.

\begin{tabular}{|l|c|c|c|c|c|}
\hline \multicolumn{1}{|c|}{ Показники рентабельності } & $\mathbf{2 0 1 4}$ p. & $\mathbf{2 0 1 5}$ p. & $\mathbf{2 0 1 6}$ p. & $\mathbf{2 0 1 7}$ p. & $\mathbf{2 0 1 8}$ p. \\
\hline Рентабельність продукції, \% & $-87,39$ & 24,09 & 24,52 & 25,91 & 24,27 \\
\hline $\begin{array}{l}\text { Рентабельність продажу за чистим } \\
\text { прибутком, \% }\end{array}$ & $-114,01$ & $-9,82$ & $-1,06$ & 1,96 & 3,31 \\
\hline $\begin{array}{l}\text { Рентабельність капіталу за чистим } \\
\text { прибутком, \% }\end{array}$ & $-9,23$ & $-8,57$ & $-0,96$ & 1,91 & 3,55 \\
\hline Рентабельність власного капіталу, \% & $-27,49$ & $-35,58$ & $-4,92$ & 10,43 & 16,31 \\
\hline Рентабельність позичкового капіталу, \% & $-13,91$ & $-11,30$ & $-1,20$ & 2,33 & 4,54 \\
\hline
\end{tabular}

Джерело: розраховано авторами за даними Державної служби статистики України.

Показник рентабельності продукції відображає одержуваний підприємством прибуток з кожної гривні, вкладеної у виробництво. У результаті аналізу цих показників та їх динаміки варто констатувати, що для досліджуваного періоду рівень рентабельності продукції достатньо низький, що визначено високою собівартістю. Цей показник майже не змінювався протягом $2015-2018$ рр.

Рентабельність продажу характеризує ефективність здійснення процесів реалізації готової продукції промислових підприємств. Дані таблиці свідчать про збитковість продажу промислової продукції протягом періоду з 2014 р. по 2016 р. Починаючи лише з 2017 р., рентабельність продажу промислової продукції характеризується позитивним значенням показника. У 2018 р. показник рентабельності продажу суттєво підвищився порівняно з 2014 р. і становить 3,31\%.

Показник рентабельності капіталу за чистим прибутком показує величину чистого прибутку, що припадає на одну гривню капіталу. Ці показники були розраховані із застосуванням чистого прибутку i протягом періоду з 2014 р. по 2016 р. мають від'ємне значення, оскільки результатом діяльності суб'єктів господарювання у промисловості є збиток. Позитивне значення показника чистого прибутку спостерігається, починаючи з 2017 р. Так, у 2017 році на одну гривню капіталу припадає лише 0,019 грн чистого прибутку та 2018 р. - 0,035 грн.

Показник рентабельності власного капіталу займає особливе місце серед показників рентабельності й показує ефективність використання власних коштів підприємства. Значення цього показника відображає ступінь привабливості підприємства для вкладення коштів інвесторів. Для досліджуваного періоду рівень рентабельності власного 
капіталу дуже низький, у 2018 р. на одну гривню власного капіталу припадало близько 0,16 грн чистого прибутку, і це найвищий рівень показника. Рівень рентабельності власного капіталу в промисловості можна підвищити за рахунок зусиль управлінського персоналу.

Аналогічна тенденція спостерігається і при аналізі показника рентабельності позичкового капіталу. Позитивне значення показника спостерігається в 2017 р. й на одну гривню позичкового капіталу припадає лише 0,02 грн прибутку та 2018 р. - 0,04 грн.

Отже, як випливає з проведеного аналізу, особливо складною була ситуація на промислових підприємствах України у 2014 р. у зв’язку з військовою агресією Росії.

Наш детальний аналіз традиційних і більш оновлених показників ефективності діяльності підприємства у різних їі проявах для оцінювання невизначеності є важливим, тому що дає можливість з'ясувати таке. Маючи достатню базу даних за різними показниками ефективності можемо скомпонувати вимірник оцінювання відхилень, наприклад, за дисперсією або за так званими gaps (розривами). Тоді мінімізація відхилень може бути потрактована як зменшення невизначеності, натомість, збільшення відхилень за певний період - як збільшення невизначеності. До прикладу, якщо йдеться про оцінювання невизначеності за показником рентабельності, то логіка оцінювання невизначеності з використанням цього традиційного показника 3 арсеналу інструментів аналізу могла б виглядати так:

$$
\sum_{i=1}^{n} \operatorname{gaps}\left(\operatorname{Prof}_{i}^{*}-\operatorname{Prof}_{\text {trend }}^{*}\right) \rightarrow 0,
$$

де $\left(\operatorname{Prof}_{i}^{*}-\operatorname{Prof}_{\text {trend }}^{*}\right)$ - відхилення фактичного значення рентабельності у конкретному році від значень тренду.

Для оцінювання ефективності підприємств в умовах невизначеності 3 урахуванням впливів конкурентного національного та глобального середовища доцільно використовувати показник EVA (Economic Value Added) - економічна додана вартість та збалансовану систему інших показників.

Модель «Економічної доданої вартості» (EVA) була розроблена Б. Стюартом і Д. Стерном та зареєстрована компанією «Stern Stewart \& Co» на початку 90-х років XX століття. Дана модель використовується такими відомими компаніями, як: «Coca-Cola», «Siemens», «IBM». На відміну від традиційних показників ефективності, показник EVA відображає тісний зв'язок з вартістю акцій і враховує фактор ризику. Даний показник дозволяє оцінити ефективність діяльності підприємства 3 позиції перетворення прибутку в його ринкову вартість [21]. 
Показник економічної доданої вартості за змістом $є$ економічним прибутком, який враховує не лише бухгалтерські витрати, але й альтернативні витрати інвестованого капіталу. Тобто, при розрахунку показника EVA із суми прибутку віднімаються не тільки витрати на залучення позичкового капіталу, а й витрати на власний капітал.

Показник EVA можна застосовувати для оцінки ефективності діяльності як підприємства загалом, так і його окремих структурних підрозділів. Його також використовують для оцінювання результатів діяльності менеджерів та їх винагородження.

Для розрахунку показника «Економічна додана вартість» використовують таку базову формулу [22]:

$$
E V A=N O P A T-(W A C C \times I C),
$$

де NOPAT - чистий операційний прибуток після оподаткування; WACC середньозважена вартість капіталу; $I C$ - інвестований капітал.

Середньозважена вартість капіталу визначається за формулою:

$$
W A C C=\frac{E}{C} \times r_{e}+\frac{D}{C} \times r_{d} \times(1-t),
$$

де $E$ - власний капітал підприємства; $C$ - загальний розмір капіталу підприємства; $D$ - позичковий капітал підприємства; $r_{e}$ i $r_{d}-$ відповідно вартість власного і позичкового капіталу, $\$ ; t$ - ставка податку на прибуток.

Для розрахунку EVA розробники внесли близько 160 поправок до статей балансу і звіту про фінансові результати, але в кожному конкретному випадку використовуються лише окремі поправки. Зокрема, поправки стосуються визначення інвестованого капіталу. Так, до останнього необхідно включати інвестиції в рекламу, навчання персоналу, дослідження та розробки, реструктуризацію бізнесу. Також складнощі у розрахунку даного показники зумовлені необхідністю визначення додаткових даних при розрахунку середньозваженої вартості капіталу, яких немає у фінансовій звітності.

Результати розрахунку економічної доданої вартості можна інтерпретувати таким чином:

- $E V A=0$. Ринкова вартість підприємства дорівнює балансовій вартості чистих активів. У власників у такому випадку немає значної зацікавленості в інвестуванні капіталу в підприємство. Прибутковість інвестування в підприємство прирівнюється до прибутковості вкладень у банківські депозити.

- EVA > 0. Ринкова вартість підприємства перевищує балансову вартість чистих активів. Висока ефективність інвестицій у підприємство і стимулює подальші вкладення капіталу власником у підприємство. 
- $E V A<0$. Ринкова вартість підприємства $є$ меншою за балансову вартість чистих активів. Власники починають втрачати інвестований у підприємство капітал. Подальші інвестиції в підприємство $є$ неефективними [23].

Загалом, застосування показника економічної доданої вартості в аналізі економіки підприємства $є$ дуже перспективним. Він дозволяє більш об'єктивно оцінити результати діяльності підприємства, порівняно 3 показником чистого прибутку. Але його застосування на вітчизняних підприємствах потребує здійснення певних змін організаційного, інформаційного, кадрового характеру. Зокрема, налагодження на підприємстві якісного ведення управлінського обліку, підготовки персоналу до впровадження відповідної моделі управління.

Потрібно також враховувати, що показник економічної доданої вартості оцінює ефективність діяльності підприємства 3 погляду його власників. Але на діяльність підприємства здійснюють вплив й інші зацікавлені особи, зокрема, персонал, менеджери, покупці, кредитори, держава. Їхні інтереси при застосуванні лише показника EVA можуть бути не враховані, що зумовлюватиме зниження вартості підприємства. За таких умов доречним $€$ поєднання використання моделі економічної доданої вартості із збалансованою системою показників. Зокрема, показник $E V A$ доцільно використовувати як один із базових показників оцінки у перспективі «Фінанси».

Збалансована система показників (ЗСП) - це новий підхід в управлінні ефективністю та аналізі суб'єктів господарювання. Вона була розроблена Р. Капланом, професором розвитку лідерства в Гарвардській школі бізнесу, та Д. Нортоном, засновником і президентом Balansed Scorecard Collaborative Inc. Методика Balansed Scorecard застосовується на підприємствах 3 метою підвищення ефективності управління за рахунок оптимального набору індикаторів діяльності. Особливістю застосування системи збалансованих показників є те, що вона складається $з$ чотирьох перспектив, за якими проводять аналіз ефективності діяльності підприємства:

- навчання та перспективи зростання (The Learning and Growth perspective);

- внутрішньофірмові процеси, внутрішні бізнес-процеси (Тhe Business Process Perspective);

- орієнтація на споживача, споживчий аспект (The Customer Perspective);

- фінансова перспектива (The Financial Perspective).

Перевагами збалансованої системи показників $є$ те, що вона включає не лише фінансові показники, а й нефінансові.

Алгоритм побудови збалансованої системи показників подано на рис. 3. 


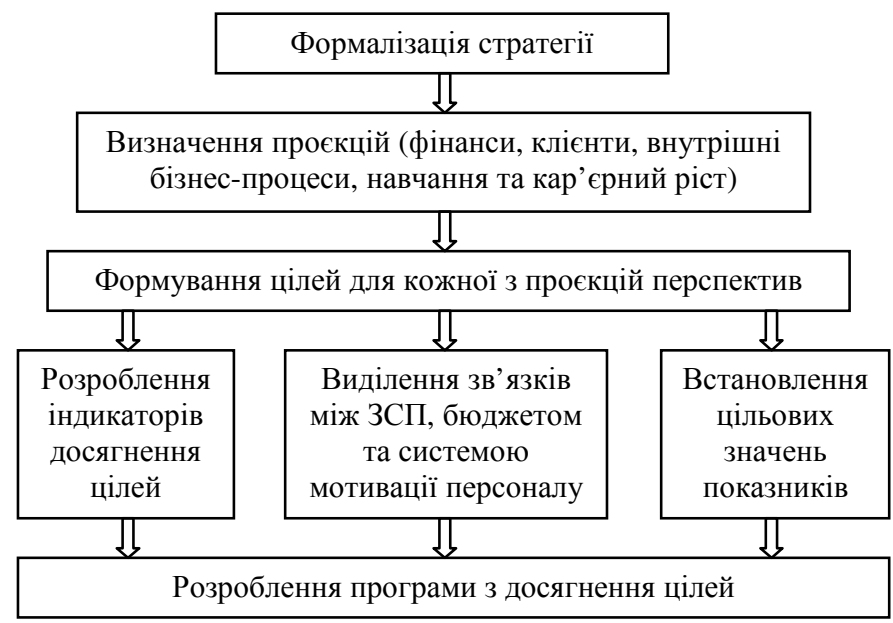

Рис. 3. Алгоритм розроблення збалансованої системи показників Джерело: складено авторами на основі [24].

На практиці підприємства обирають ті показники, які найбільше відповідають його стратегічній меті. Також підприємства можуть додавати п'ятий вектор до чотирьох перерахованих вище або замінювати на той, який найкраще зможе відобразити стратегію конкретного підприємства.

Як ми бачимо, специфіка збалансованої системи показників полягає в тому, що немає єдиного універсального переліку показників, які можна було б використати для аналізу діяльності того чи того підприємства. Вони формуються індивідуально для кожного підприємства, виходячи 3 його цілей. Тому на рис. 4 нами запропоновано перелік показників за кожною із чотирьох перспектив, які можна використовувати промисловим підприємствам при побудові збалансованої системи показників.

Практична цінність збалансованої системи показників полягає у вирішенні проблеми досягнення стратегічних цілей, що $є$ важливим для будь-яких підприємств, незалежно від галузі функціонування. Оптимальний набір показників, які кожне підприємство може обрати самостійно відповідно до своєї стратегічної мети, підвищить цінність прогнозної інформації для управління. Він дозволить оперативно коригувати управлінські рішення; дасть змогу за допомогою нефінансових показників оцінювати ефективність діяльності підприємства, його конкурентоспроможність; зробить діяльність українських підприємств більш прозорою для можливих інвесторів. 


\begin{tabular}{|c|c|c|c|}
\hline & балансована систе & показників & \\
\hline $\begin{array}{c}\text { Фінансова } \\
\text { перспектива } \\
\text { - економічна додана } \\
\text { вартість (ЕVА); } \\
\text { - чистий прибуток; } \\
\text { - показники } \\
\text { рентабельності; } \\
\text { - коєфіцієнти } \\
\text { ліквідності та } \\
\text { платоспроможності; } \\
\text { - показники } \\
\text { фінансової } \\
\text { стійкості. }\end{array}$ & $\begin{array}{c}\text { Внутрішні } \\
\text { бізнес-процеси } \\
\text { - частка інноваційної } \\
\text { продукції; } \\
\text { - тривалість } \\
\text { виробничого циклу; } \\
\text { - затримка в } \\
\text { постачанні } \\
\text { підприємства } \\
\text { матеріалами; } \\
\text { - витрати за } \\
\text { основними бізнес- } \\
\text { процесами; } \\
\text { - частка бракованої } \\
\text { продукції. }\end{array}$ & $\begin{array}{c}\text { Споживча } \\
\text { перспектива } \\
\text { - частка ринку; } \\
\text { - лояльність } \\
\text { клієнтів; } \\
\text { - рівень } \\
\text { відпускних } \\
\text { цін; } \\
\text { - кількість } \\
\text { рекламацій; } \\
\text { - темпи } \\
\text { зростання } \\
\text { ринку. }\end{array}$ & $\begin{array}{c}\text { Перспектива } \\
\text { навчання та } \\
\text { зростання персоналу } \\
\text { - ступінь } \\
\text { задоволення } \\
\text { працівників; } \\
\text { - плинність } \\
\text { персоналу; } \\
\text { - продуктивність } \\
\text { праці; } \\
\text { - коєфіцієнт } \\
\text { підвищення } \\
\text { кваліфікації; } \\
\text { - видані винагороди } \\
\text { та премії. }\end{array}$ \\
\hline
\end{tabular}

Рис. 4. Показники, які можуть бути використані при побудові ЗСП для промислових підприємств

Джерело: складено авторами самостійно.

До важливих інструментів оцінювання невизначеності діяльності підприємства слід віднести методи ідентифікації ризиків. Сучасні методи оцінки ризиків варто поділити на дві групи: якісні та кількісні.

Якісні методи використовуються на початковому етапі аналізу. Їх основною задачею $\epsilon$ виявлення основних ризиків, які виникають у процесі фінансово-господарської діяльності підприємства. Більшість науковців відзначають складність застосування якісних методів. Ідеться про те, що для їх застосування фахівці повинні мати грунтовні знання 3 економіки, фінансів, значний практичний досвід роботи у відповідній сфері діяльності.

Продовженням якісного аналізу обов'язково повинен бути кількісний аналіз ризиків. Його результати надають інформацію щодо кількісної величини окремих ризиків, а не сукупного ризику діяльності підприємства [25].

Розглянемо найпоширеніші методи оцінки ризиків підприємства.

Експертний метод вважається більш суб' єктивним, адже базується на судженнях експертів. Його доцільно використовувати при недостатній інформації, що $\epsilon$ його істотною перевагою над іншими методами оцінки ризиків підприємства. При цьому експертна оцінка найчастіше здійснюється з використанням методу «Делфі». Він базується на проведенні серії послідовних опитувань експертів без особистих дебатів між ними. Повторення процедури опитування дозволяє експертам ще раз переглянути 
свої судження, проаналізувати інформацію, надану іншими експертами. Так досягається одержання точнішої інформації. Також при використанні даного методу застосовують диференційовані оцінки, коли судженням окремих експертів надається більша вагомість. Однак при використанні методу «Делфі» потрібно досить ретельно підходити до формулювання питань анкети, щоб вони були чітко сформульовані й найбільш повно розкривали проблему. Загалом експертний метод заслуговує на увагу, але лише на початкових етапах оцінювання ризиків діяльності підприємства [26].

На підставі використання методу експертних оцінок застосовують методику Швейцарської банківської корпорації [27]. Дана методика складається 3 чотирьох етапів: визначення напрямку аналізу; збір, групування вихідних даних; визначення ступеня ризику; визначення сукупного ступеня ризику. На підставі даної методики можна зробити висновок про фінансову стійкість економіки, а отже, і про рівень ділової активності суб'єктів господарювання. А також ії перевагою є можливість вибору оптимального варіанту розвитку діяльності підприємства.

Для визначення ступеня ризику використовують методику, розроблену фірмою BERI (Німеччина) [28]. За даною методикою розраховується спеціальний індекс (на підставі опитування 100 незалежних експертів), який дає змогу оцінити ступінь ризику.

Метод аналогій. Його суть базується на оцінюванні ризиків шляхом аналізу інформації за подібними за рівнем ризику проєктах. Складнощі в застосуванні даного методу полягають у виборі аналога. Складно знайти подібний проєкт, який ще буде реалізовуватися в аналогічних умовах зовнішнього середовища. Цей метод доцільно використовувати в тих випадках, якщо підприємство нещодавно реалізувало однотипний проєкт і $є$ вся необхідна інформація щодо нього.

Аналіз доцільності витрат. Даний метод базується на різних рівнях ризику витрат за кожним напрямом діяльності. Для цього аналізується кожен елемент витрат. Залежно від фактичного стану кожного 3 них роблять висновки щодо можливої зони витрат. Таким чином, метод доцільності витрат дозволяє виявити «вузькі» місця в діяльності підприємства з позиції ризикованості [29].

Статистичний метод дозволяє оцінити ризик діяльності підприємства на основі статистичних даних за минулий період. Якщо $є$ достатньо інформації про основні ризики діяльності підприємства у минулих періодах, то можна здійснити оцінку ймовірності їх виникнення у майбутньому.

Основними показниками, які розраховуються у статистичному методі, є: математичне очікування, дисперсія, середньоквадратичне відхилення, коєфіцієнт варіації [30]. 
Математичне очікування $M(x)$ дозволяє визначити найімовірніший результат, який можна отримати у майбутньому:

$$
M(x)=\sum_{i=1}^{n} x_{i} \times p_{i},
$$

де $x_{i}-$ значення випадкової величини залежно від конкретних умов; $p_{i}-$ ймовірність можливих значень випадкової величини.

Дисперсія $D(x)$ :

$$
D(x)=\sum_{i=1}^{n} p_{i} \times\left(x_{i}-M(x)\right)^{2} .
$$

Середньоквадратичне відхилення $\sigma$ :

$$
\sigma=\sqrt{D(x)}
$$

Вище значення середньоквадратичного відхилення свідчить про вищий ризик діяльності підприємства.

Коєфіцієнт варіації $V$ :

$$
V=\frac{\sigma}{M(x)} .
$$

Коєфіцієнт варіації може мати значення від 0 до 100\%. Чим вище його значення, тим вищий ризик підприємницької діяльності.

Статистичний метод $\epsilon$ досить простий у розрахунках. За його допомогою визначають можливість настання втрат та рівень ризику, однак він потребує значної кількості вихідної інформації. Це може зумовити складнощі у його використанні. А через те, що в майбутньому можливий вплив факторів, яких не було в минулих періодах, статистичний метод не дозволяє достовірно оцінити рівень витрат у майбутньому. Крім того, не доцільно використовувати статистичний метод, якщо досліджується нове підприємство.

Метод Монте-Карло є методом імітаційного моделювання, що забезпечує моделювання випадкових величин. Даний метод передбачає, що спочатку для цільової випадкової величини генерується набір випадкових значень, які $є$ відмінними один від одного. Далі цю множину випадкових значень обробляють за допомогою методів математичної статистики.

Метод Монте-Карло передбачає чітку послідовність дій при оцінюванні ризиків. Алгоритм оцінювання передбачає такі кроки:

1. Формування прогнозної моделі.

2. Визначення ключових чинників ризику.

3. Встановлення умов кореляції між результативним показником і змінними. 
4. Вибір характеру розподілу ймовірностей.

5. Імітаційне моделювання випадкових сценаріїв реалізації.

6. Аналіз отриманих результатів за допомогою статистичної оцінки [31].

Метод Монте-Карло вважається досить точним при оцінюванні ризиків, оскільки моделювання сценаріїв здійснюється автоматично, що виключає суб'єктивні оцінки. Але даний метод вимагає значних затрат часу та інформаційних ресурсів. Переваги цього методу в оцінюванні економічної невизначеності є очевидними і незаперечними.

За результатами дослідження можна зробити такі висновки:

- традиційні інструменти оцінювання невизначеності є достатньо простими для реалізації, але забезпечують «поверхневий» результат, даючи достатньо обмежену відповідь на питання, яким був або яким $є$ вплив невизначеності на діяльність підприємства;

- «глибший», у сенсі точніший, результат забезпечується при застосовуванні новітніх інструментів аналізу, зокрема показник EVA, a також при використанні збалансованої системи показників, методу експертних оцінок, методу аналогій, при аналізі доцільності витрат тощо;

- в аналізі не доцільно обмежуватися лише одним методом, оскільки вища точність та об'єктивність результатів оцінки ризиків досягається при використанні декількох методів.

\section{תimepamypa:}

1. Frank H. Knight, Ph.D. Risk, Uncertainty and Profit. Boston and New York, Houghton Mifflin Co., The Riverside Press, 1921.

2. Kallman J. Instructors' manual, the Tools \& Techniques of Risk Management \& Insurance. National Underwriter, Cincinnati, OH, 2007.

3. Crouhy M., Galai D., Mark R. Risk Management. New York : McGraw-Hill, 2012. 390 p.

4. Mccarthy M., Flynn T. Risk From the CEO and Board Perspective: What All Managers Need to Know About Growth in a Turbulent World. New York : McGraw Hill, 2003. 256 p.

5. Розвиток економічної науки видатними науковцями з української діаспори : матеріали науково-практичної конференції (Київ, 3 квітня 2020 р.). Вищий навчальний заклад «Університет економіки та права «КРОК», 2020. $33 \mathrm{c}$.

6. Петти В., Смит А., Рикардо Д., Кейнс Дж., Фридмен М. Классика экономической мысли: Сочинения. Москва : ЭКСМО-Пресс, 2000. $753 \mathrm{c}$.

7. Рикардо Д. Сочинения: в пяти томах. Москва : Госполитиздат, 1955. T. $1.360 \mathrm{c}$. 
8. Маркс К., Энгельс Ф. Критика политической экономии. Сочинения. 2-е изд. Москва : Политиздат, 1968. Соч. 46. Ч. 1. С. 533.

9. Макконелл К. Р., Брю С. Л. Экономикс: Принципы, проблемы и політика. Москва : Республика, 1992. 799 с.

10. Leibenstein H. Allocative Efficiency and X-Efficiency. The American Economic Review. 1966. №56. P. 392-415.

11. Oxford Dictionaries. URL : https://www.lexico.com/definition/ efficiency.

12. Oxford Dictionaries. URL : https://www.lexico.com/definition/ effectiveness.

13. Друкер П. Классические работы по менеджменту. Москва : Юнайтед пресс, 2010. 224 с.

14. ДСТУ ISO 9000:2007 Системи управління якістю. Основні положення та словник термінів (ISO 9000:2005, IDT). Чинний від 200801-01. Вид. офіц. Київ : Держспоживстандарт України, 2008. 31 с.

15. Measuring Productivity : Measurement of Aggregate and Industrylevel Productivity Growth. OECD Manual. Paris : OECD, 2001. P. 126-127.

16. Андрійчук В. Г. Ефективність діяльності аграрних підприємств: теорія, методика, аналіз : монографія. Київ : КНЕУ, 2005. 292 с.

17. Любкіна О. В. Діагностика фінансової діяльності i прогнозування перспектив розвитку бізнесу на основі баготофакторної моделі рентабельності. Ефективна економіка. 2018. №3. URL : http://www.economy.nayka.com.ua/pdf/3_2018/48.pdf.

18. Лелюк О. О. Особливості аналізу ефективності використання капіталу агропромислових формувань. Вчені записки Університету «КРОК».2009. Вип. 20. Т. II. С. 217-227.

19. Кошельок Г. В., Малишко В. С. Факторний аналіз рентабельності власного капіталу. URL : http://dspace.oneu.edu.ua/jspui/bitstream.

20. Розвиток промисловості для забезпечення зростання та оновлення української економіки : Науково-аналітична доповідь / За ред. Дейнеко Л. В. ; НАН України, ДУ «Ін-т екон. та прогнозув. НАН України». Київ, 2018. 158 с. С. 15.

21. Спільник I. Аналіз економічної доданої вартості підприємства. Економічний аналіз. 2013. Вип. 12. Ч. 4. С. 70-74.

22. Rowland Z. Decomposition of EVA Equity to the Sub-operational Plans of a Company. Littera Scripta. 2016. №9(3). C. 52-65.

23. Свідерська I. М. Економічна додана вартість: теоретичні аспекти розрахунку та використання показника. Економіка та держава. 2013. №11. C. 52-54.

24. Нівен Пол Р. Діагностика збалансованої системи показників: Підтримуючи максимальну ефективність / Пер. 3 англ.; за наук. ред. М. Горського. Дніпропетровськ : Баланс Бізнес Букс, 2006. 256 с. 
25. Петрова В. Ф. Методичне забезпечення оцінки ризиків підприємства. Соціальна економіка. 2015. Вип. 50. №2. С. 148-153.

26. Пернарівський О. В., Орловська Ю. М. Використання експертних методів при оцінюванні системного ризику в банківській діяльності. Прачі Одеського політехнічного університету. 2011. Вип. 3(37). С. 52-57.

27. Клименко С. М., Дуброва О. С. Обгрунтування господарських рішень та оцінка ризиків : навч. посібник. Київ : КНЕУ, 2005. 252 с.

28. Kobrin S. J. Political Risk: A Review And Reconsideration. Journal of International Business Studies, Palgrave Macmillan. Academy of International Business. Vol. 10(1). P. 67-80.

29. Сорочак О. З., Олійник Р. В. Методи кількісного аналізу та управління проектними ризиками. URL : http:/ena.lp.edu.ua:8080/ bitstream/ntb/16669/1/411-698-699.pdf.

30. Михальчук А. В., Вербицька К. С. Підприємницький ризик: функції, методи оцінки та шляхи зниження ризику. Вісник ЖДТУ. 2015. №2(72). С. 162-168.

31. Жентичка Ю. Ю. Використання методу Монте-Карло для розрахунку фінансово-виробничого ризику. URL : http://libfor.com/ index.php?newsid=2418. 


\title{
КОНКУРЕНТНА СПРОМОЖНІСТЬ ПІДПРИЕМСТВ ДЛЯ ЕКОНОМІЧНОЇ СТАБІЛЬНОСТІ ТА ПЕРЕДБАЧУВАНОСТІ
}

\author{
Пекна Галина Борисівна, \\ кандидат економічних наук, дочент, \\ дочент кафедри теоретичної та прикладної економіки, \\ ВНЗ «Університет економіки та права «КРОК», \\ ORCID: https://orcid.org/0000-0003-4902-6052
}

Анотація. Розділ присвячено дослідженню явища конкурентної спроможності підприємств під кутом зору її зв'язку зі стабільністю й передбачуваністю результатів діяльності. Економіка окремих підприємств, як і загалом національна економіка, має оцінюватися за певними критеріями визначеності та стабільності. Саме конкурентна спроможність стає важливою передумовою визначеності, стабільності підприємства, а отже, й передбачуваності результатів. Такий підхід набуває актуальності в умовах сучасної зростаючої економічної невизначеності. Для його практичної реалізації доцільно уточнити зміст поняття (явища) конкурентної спроможності на різних рівнях ії̈ здійснення та дослідити способи ії оцінювання.

Ключові слова: конкурентна спроможність підприємства, товару, галузі, економіки, методи оцінювання конкурентної спроможності.

Швидкі неочікувані зміни кон'юнктури національного та світового ринків, перманентні зміни технологій, особливо, у сфері комунікацій, часто діють не на користь суб'єктів підприємницької діяльності. Підприємства, що функціонують в умовах високого рівня невизначеності та неочікуваних впливів, $є$ найбільш загроженими. Для протидії загрозам необхідні механізми швидкого реагування на зміни. Йдеться про те, що сьогодні називають «управління змінами» й що корелює 3 формуванням конкурентної спроможності підприємства.

Сучасні стратегії забезпечення конкурентної спроможності підприємств покликані вирішувати об'єктивно існуючу суперечність. Це - суперечність між досягненням максимальної стабільності та ефективності використання ресурсів у поточному періоді, з одного боку, та формуванням передумов для змін у майбутньому - з іншого. У цьому, на наш погляд, насамперед має виявлятися конкурентна спроможність підприємств за умов невизначеності.

На жаль, підхід до конкурентної спроможності на засадах вирішення суперечності між «завданням на сьогодні» та «завданням для майбутнього» не віддзеркалено в українському законодавстві. Зокрема, за Законом України «Про захист економічної конкуренції», остання потрактована лише як здобута перевага над іншими. У Законі 
зазначено: «Економічна конкуренція (конкуренція) - змагання між суб'єктами господарювання 3 метою здобуття завдяки власним досягненням переваг над іншими суб'єктами господарювання, внаслідок чого споживачі, суб'єкти господарювання мають можливість вибирати між кількома продавцями, покупцями, а окремий суб'єкт господарювання не може визначати умови обороту товарів на ринку» [1]. Як свідчить наведена стаття Закону, економічна конкуренція розглядається лише як боротьба, змагання, суперництво з іншими за переваги на ринку.

Інші чинні закони - Закон України «Про захист від недобросовісної конкуренції», Закон України «Про застосування спеціальних заходів щодо імпорту в Україну» - акцентують увагу на способах регламентації економічної діяльності. Ці нормативні документи не створюють підгрунтя для формування інструментарію для вирішення суперечності між стабільністю та мінливістю [2; 3].

У науковому обігу циркулюють різні визначення конкуренції, наповнені дещо відмінним змістом. У нашому дослідженні зміст поняття «конкуренція» $є$ особливо важливим. Адже від того, який зміст вкладено в це поняття, залежить і зміст поняття «конкурентна спроможність».

Спеціальні дослідження, присвячені проблемі еволюції поняття «конкуренція», дають підстави для деяких важливих узагальнень. Такі дослідження здійснюються, зокрема, й вітчизняними науковцями [4]. 3 усього масиву визначень конкуренції, на наш погляд, необхідно виокремити дві групи, а саме:

- визначення, що розкривають необхідні умови функціонування ринку як конкурентного й стосуються кількості виробників і споживачів, які діють на ринку, а також свободи входження на ринок та виходу з нього;

- визначення, в яких акцентується увага на інструментах (способах реалізаиіï) перемоги у конкурентній боротьбі.

При більш детальному аналізі змісту поняття «конкуренція», 3'ясовується, що в якості ії проявів розглядаються, крім традиційних, які виявляються у суперництві, й інші, а саме:

- динамізм економіки, постійне впровадження нових технологій у виробництво, управління та комунікації зі споживачами та партнерами, формування нових організаційних структур;

- максимізація прибутку на основі додаткових витрат, пов'язаних 3 дослідженнями ринків та створенням інноваційних форм просування власного товару;

- прагнення убезпечитися від негативних наслідків ринкового суперництва з відповідним діями, спрямованими на змову між колишніми конкурентами та на монополізацію ринку, що актуалізує примусові антимонопольні дії урядів для захисту конкурентного середовища.

Як відомо, конкуренція постійно модифікується, набуваючи нових форм. Класик теорії конкуренції М. Портер виокремлює п'ять 
рушійних сил конкуренції, під впливом яких відбуваються ії зміни. Показово те, що серед цих рушіїв акцентовано потенційні загрози бути витісненими 3 ринку більш успішними виробниками. Виокремлено також чинник створення іншими виробниками товарів-замінників 3 кращими або новими споживчими властивостями [5]. Зрозуміло, що згадані рушійні сили конкуренції формують економічну невизначеність підприємства. Адже достатньо важко й, здебільшого, неможливо передбачити дії інших «гравців ринку».

Ми вважаємо принципово важливим те, що конкуренція - це відносини з ознаками постійних змін у формах та способах ведення бізнесу, з ризиками невизначеності. Тому конкурентна спроможність це здатність діяти саме в таких мінливих, ризикових умовах, які передбачають додаткові витрати, пов'язані не просто з суперництвом, а й 3 пристосуванням до мінливого середовища. У цьому сенсі конкурентна спроможність підприємства постає не стільки як суперництво 3 іншими «гравцями» ринку, скільки як «суперництво 3 самим собою». Йдеться про суперечність між підприємством у його старому (традиційному) стані й ним же у новому стані. При цьому, новий стан має відповідати новим умовам провадження бізнесу, новим технологіям та потребам. Це - особливе діалектичне заперечення новим станом підприємства його старого стану, яке і $є$ розвитком.

Пропоноване нами визначення конкурентної спроможності відповідає завданню цього розділу - дослідити конкурентну спроможність підприємства під кутом зору економічної невизначеності. Однак, існують інші визначення конкурентної спроможності, які сформувалися в інших контекстах. Саме такі інші контексти вимагали інших акцентів у визначеннях конкурентної спроможності.

Конкурентна спроможність підприємства у багатьох дослідженнях асоціюється (пов'язується) 3 конкурентною спроможністю товарів, конкурентною спроможністю галузей (секторів) економіки та 3 конкурентною спроможністю всієї національної економіки. Цей зв’язок може бути поданий у такий спосіб (рис. 1).

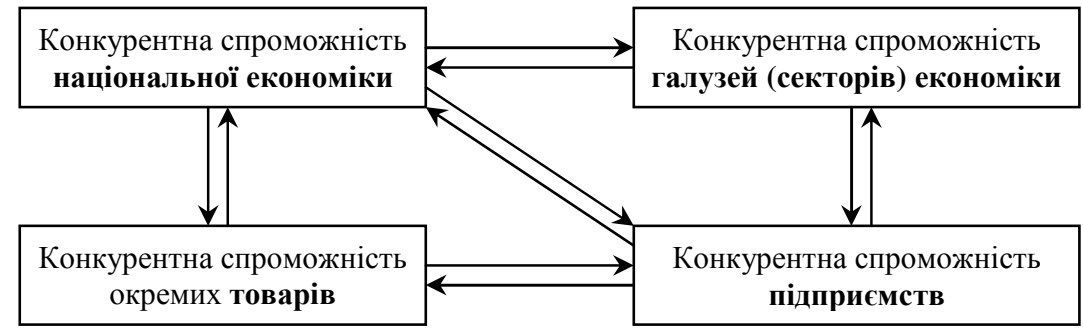

Рис. 1. Взаємозв'язок рівнів конкурентної спроможності Джерело: створено автором самостійно. 
На рис. 1 ілюстровано ідею взаємної залежності чотирьох рівнів (проявів) конкурентної спроможності, а саме: всієї національної економіки, іiї галузей (секторів), підприємств та окремих товарів.

Конкурентна спроможність окремого підприємства, яка $\epsilon$ об'єктом нашого дослідження, формується під впливом конкурентної спроможності галузі. У той же час, конкурентна спроможність кожного підприємства формує конкурентну спроможність галузі, в якій вони функціонують. Остання, природно, збільшується зі збільшенням кількості конкурентоспроможних підприємств.

Конкурентна спроможність підприємства реалізується через конкурентну спроможність створюваних ним товарів. I, навпаки, конкурентна спроможність товарів формує конкурентну спроможність підприємства.

Ще однією лінією зв'язку конкурентної спроможності підприємства є іiї залежність від конкурентної спроможності національної економіки. Остання, за нашим уявленням, відіграє роль своєрідного «зовнішнього середовища» сприяння конкуренції на всіх рівнях.

3 аналізу українських досліджень у царині проблем конкурентної спроможності підприємства можна зробити такий висновок. Достатньо часто вона визначається та оцінюється через конкурентну спроможність створюваних товарів [6; 7]. Рідше конкурентна спроможність підприємства пов'язується у визначеннях та оцінках з конкурентною спроможністю галузі та усієї національної економіки [8].

Погоджуючись з ідеєю пов' язаності понять (явищ) конкурентної спроможності економіки, галузі, підприємства та окремого товару, ми вважаємо доцільним якомога більш чітке їх розмежування. Йдеться про з'ясування не лише спільного, а й особливого (відмінного) у змісті цих понять. Лише у такий спосіб може бути створене підгрунтя для розробки конкретних методик оцінювання різних рівнів конкурентної спроможності.

3 огляду на необхідність уточнення змісту конкурентної спроможності підприємства, галузі та окремого товару, зробимо деякі узагальнення.

Конкурентна спроможність галузі здебільшого пов'язується 3 наявністю в ній умов для створення інноваційної продукції та 3 упровадженням продуктів сектору досліджень та розробок (R\&D) [9; 10]. Економетричне оцінювання рівня конкурентної спроможності галузі часто здійснюється з використанням ідей моделі Портера (Porter's diamond mode) [11].

Зрозуміло, що конкурентна спроможність певної галузі може визначатися та оцінюватися порівняно з:

а) подібними галузями в інших національних економіках;

б) іншими галузями власної національної економіки. 
3 огляду на можливість оцінювання конкурентної спроможності галузі на тлі подібних галузей в інших економіках, для більшості країн світу актуальним $\epsilon$ не власне факт перемоги, а здатність брати участь у суперництві. Тобто, йдеться про здатність посідати достойне місце у світовій ієрархії подібних галузей. Така здатність галузі, на наш погляд, може оцінюватися принаймні за такими показниками, як:

- співвідношення внутрішніх та зовнішніх цін на продукцію галузі $\left(P_{d} / P_{f}=k_{P}\right)$;

- інвестиційна привабливість галузі для зовнішніх інвесторів, оцінювана за співвідношенням рівнів доходності інвестицій, тобто процентів на вкладений капітал за кордоном та всередині країни $\left(i_{d} / i_{f}=k_{i}\right)$;

- частка галузі у формуванні пропозиції на міжнародному ринку продукції цієї галузі $\left(S_{d} / S=d_{S}\right)$.

3 використанням пропонованих показників міг би розраховуватися індекс зовнішньої конкурентної спроможності галузі ( $\left.I_{C o m p / i}^{E x t}\right)$. При цьому нормування фактичних значень трьох визначених нами показників $\left(k_{P}, k_{i}, d_{S}\right)$ на тлі подібних значень показників обраної для порівняння групи країн могло б здійснюватися за формулою [1]:

$$
y_{i}=\left(x_{\text {краме }}-x_{\text {факт }}\right) /\left(x_{\text {краме }}-x_{\text {гірие }}\right) \text {, }
$$

де, $\mathrm{y}_{\mathrm{i}}-$ нормоване значення фактичного показника, $x_{\text {факт }}, x_{\text {краще }}, x_{\text {zipuе - }}$ відповідно, фактичне значення показника досліджуваної країни, краще значення показника в групі країн, що відібрана для порівняння, гірше значення показника в групі країн, відібраних для порівняння.

Вагові коєфіцієнти при трьох показниках $-k_{P}, k_{i}, d_{S}-$ для розрахунку інтегрального індексу могло б визначатися 3 використанням поширених прийомів: або шляхом експертного оцінювання, або статистичним методом головних компонент.

Конкурентна спроможність галузі на тлі інших галузей власної національної економіки, тобто внутрішня конкурентна спроможність галузі, може оцінюватися, наприклад, за такими показниками:

- часткою галузі у створенні доданої вартості (ВВП) національної економіки $\left(Y_{i} / Y=d_{Y i}\right)$;

- часткою інноваційної продукції у структурі виробництва галузі $\left(Y_{I n} / Y_{i}=d_{Y i / I n}\right)$;

- продуктивністю праці в галузі $\left(Y_{i} / L_{i}=k_{Y / L}\right)$;

- середньою рентабельністю підприємств галузі $\left(R^{*}\right)$.

За потреби розрахунку індексу внутрішньої конкурентної спроможності галузі міг би застосовуватися той же підхід, що й при визначенні зовнішньої конкурентної спроможності. Логіка нормування показників мала б бути тією ж з єдиною відмінністю. Тут мали б порівнюватися не показники подібних галузей різних країн, а показники різних галузей національної економіки. Залежно від покладених в 
основу оцінювання принципів, для порівняння могли би братися або всі галузі економіки, або галузі, технологічно найближчі до досліджуваної. Вагові коєфіцієнти при чотирьох згаданих показниках при розрахунку інтегрального індексу могли б також оцінюватися 3 використанням поширених прийомів статистичного аналізу.

Конкурентна спроможність товару здебільшого трактується як його здатність задовольняти попит споживачів, виявляючи конкурентні переваги над іншими товарами через:

- споживчі властивості, технічні характеристики, іміджеві ознаки;

- відносний (на тлі імпортованих товарів та вітчизняних товарівзамінників) рівень цін;

- тривалість присутності товару на ринку тощо.

3 огляду на зв'язок конкурентної спроможності підприємства 3 конкурентною спроможністю галузі та створюваних товарів, доречне таке уточнення. Конкурентна спроможність підприємства - це його здатність до змагання за частку ринку, до вирішення суперечності між поточним і необхідним майбутнім потенціалом, яка формується конкурентною спроможністю галузі та створюваних ним товарів.

Принципово важливим $є$ питання зв'язку між конкурентною спроможністю підприємства й конкурентною спроможністю національної економіки. На наш погляд (і це віддзеркалено на рис. 1), конкурентна спроможність національної економіки пов'язана 3 конкурентною спроможністю підприємства й опосередковано, й безпосередньо.

Напрямки безпосереднього впливу конкурентної спроможності національної економіки на конкурентоспроможність підприємства виявляються, зокрема, в структурі індексу глобальної конкурентної спроможності $\left(I_{G C I}\right)$.

Як відомо, індекс глобальної конкурентоспроможності (The Global Competitiveness Index) щороку визначається міжнародною організацією Всесвітнім економічним форумом (ВЕФ) - для всіх країн світу. Це дає можливість сформувати рейтинг країн. Саме місце кожної країни в цьому рейтингу й віддзеркалює рівень іiї національної економічної конкурентної спроможності. Індекс $\left(I_{G C I}\right)$ має високий рівень довіри, оскільки формується за прозорою методикою 3 використанням загальнодоступних статистичних даних і результатів глобального соціологічного опитування. Останнє $є$ щорічним дослідженням ВЕФ разом з мережею партнерських організацій - провідних дослідницьких інститутів світу.

Індекс глобальної конкурентоспроможності розраховується за 12 напрямками оцінювання. Саме перелік та зміст цих напрямків оцінювання $є$ принципово важливим для нашого дослідження. Індекс $\left(I_{G C I}\right)$ охоплює такі структурні елементи - напрямки оцінювання 3 використанням набору показників: 
- макроекономічна стабільність;

- споживчий ринок;

- ринок праці;

- фінансова система;

- розмір внутрішнього ринку;

- якість інститутів;

- стан інфраструктури;

- рівень проникнення IT і сучасних комунікацій;

- здоров'я населення;

- освіта і навички;

- динаміка бізнес-розвитку;

- здатність до інноваиій.

На наш погляд, більшість зі згаданих 12-х напрямків оцінювання конкурентної спроможності національної економіки може тлумачитися як напрямки впливу на конкурентну спроможність окремого підприємства. Це передусім ті 3 них, які сприяють стабільності й вищому рівню визначеності результатів діяльності підприємства. До них ми відносимо: макроекономічну стабільність, фінансову систему, якість інститутів, стан інфраструктури, здатність до інновацій.

У рейтингу, за індексом глобальної конкурентоспроможності, Україна посідає місця, нижчі від середнього рівня. Динаміка місця нашої країни у світовому рейтингу ілюстрована на рис. 2.

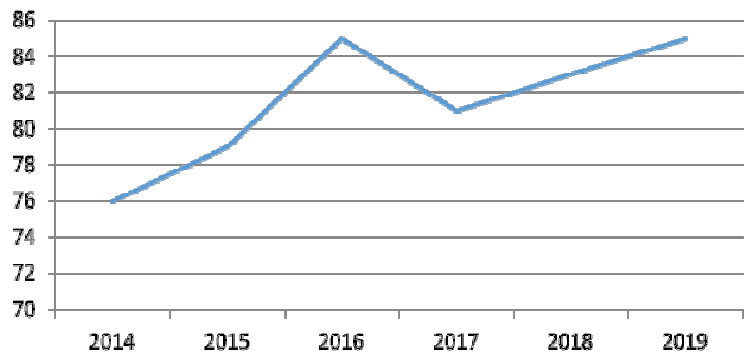

Рис. 2. Україна в міжнародному рейтингу конкурентоспроможності Джерело: власна розробка автора на основі джерела [12].

Як свідчить інформація, ілюстрована на рис. 2, у період 2014 2019 рр. найкращим було 77 місце України в рейтингу економічної конкурентної спроможності. У подальшому було втрачено 8 позицій рейтингу.

Важливим для аналізу загальної економічної конкурентної спроможності є оцінювання на тлі інших країн - компаративний аналіз «найближчого оточення» в рейтингу. Такий аналіз можна здійснити 3 використанням і загальної інформації, поданої на рис. 3. 


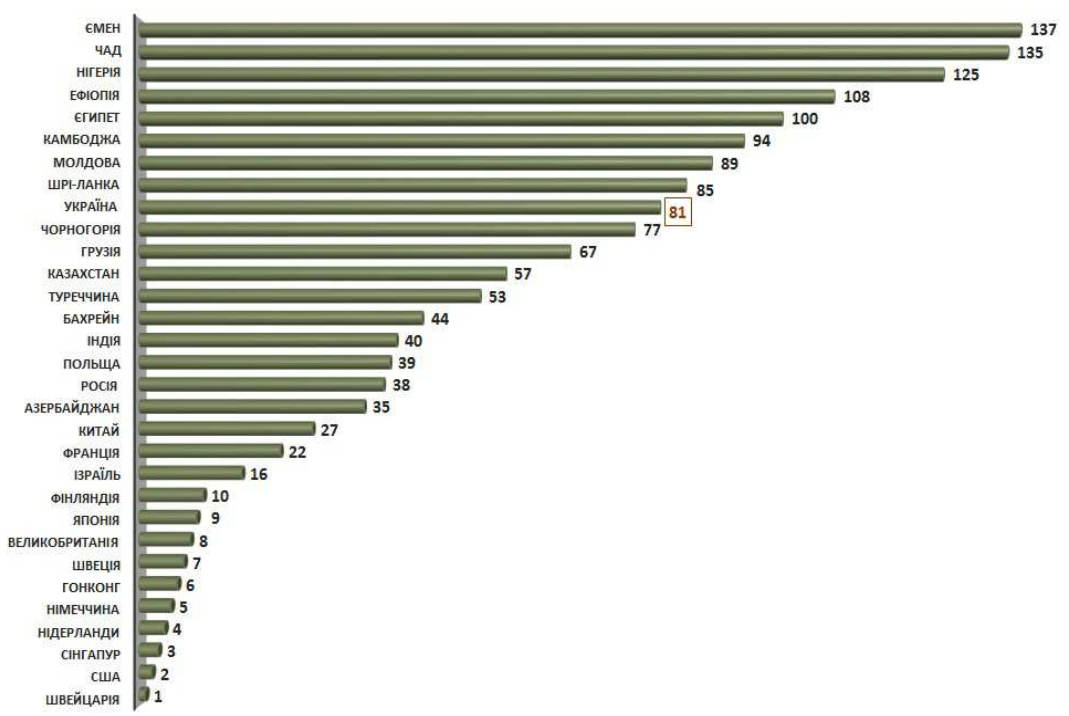

Рис. 3. Позиція України у світовому рейтингу, за індексом глобальної економічної конкурентоспроможності $\left(I_{G C I}\right)$ Джерело: [13].

За інформацією 3 рис. 3, перебуваючи у нижчій половині рейтингу, українська економіка відстала від переважної більшості постсоціалістичних країн, демонструючи гірші показники.

Принципово важливим для аналізу конкурентної спроможності $\epsilon$ ідентифікація причин погіршення місця країни у світовому рейтингу. До прикладу, в 2018 році, посівши загальне 81 -е місце у рейтингу $I_{G C l}$, Україна мала кращі місця за такими конкретними напрямками:

- 46-е - за рівнем освіти;

- 58-е - за рівнем інноваційних можливостей;

- 66-е -за станом ринку праці;

- 77-е місце за рівнем проникнення сучасних технологій.

Натомість, гіршими від загального значення місця України у рейтингу були показники за такими напрямками:

- 94-е - за станом охорони здоров'я;

- 110-е - за рівнем розвитку державних інститутів;

- 131-е - за рівнем макроекономічної стабільності.

Оскільки, незаперечно, існує зв'язок загальної конкурентної спроможності національної економіки та конкурентної спроможності підприємства, то передбачення щодо спроможності окремих підприємств мали б враховувати принаймні такі обставини:

- динаміку національної конкурентоспроможності; 
- зміни впливів окремих напрямків, відповідно, показників на покращення або, навпаки, погіршення місця країни у світових рейтингах конкурентоспроможності.

Для кількісного оцінювання конкурентної спроможності підприємств, 3 використанням певних методик, доцільно дослідити акценти у визначеннях цього явища. 3 огляду на акценти, можна виокремити такі підходи до змісту конкурентної спроможності підприємства:

- $з$ позиції залежності від конкурентної спроможності створюваних товарів;

- 3 позиції залежності від конкурентної спроможності галузі та всієї національної економіки;

- 3 позиції рівня ефективності використання ресурсів;

- $з$ позиції формування людського капіталу;

- 3 позиції змагальності з іншими операторами ринку;

- $з$ позиції здатності до адаптації в конкретних умовах.

Використовувані на практиці методики оцінювання конкурентної спроможності підприємств здебільшого спираються на згадані підходи або на їх окремі фрагменти.

3 великої сукупності методів оцінювання конкурентної спроможності підприємства можна, за певними критеріями, виокремити їх групи (рис. 4).

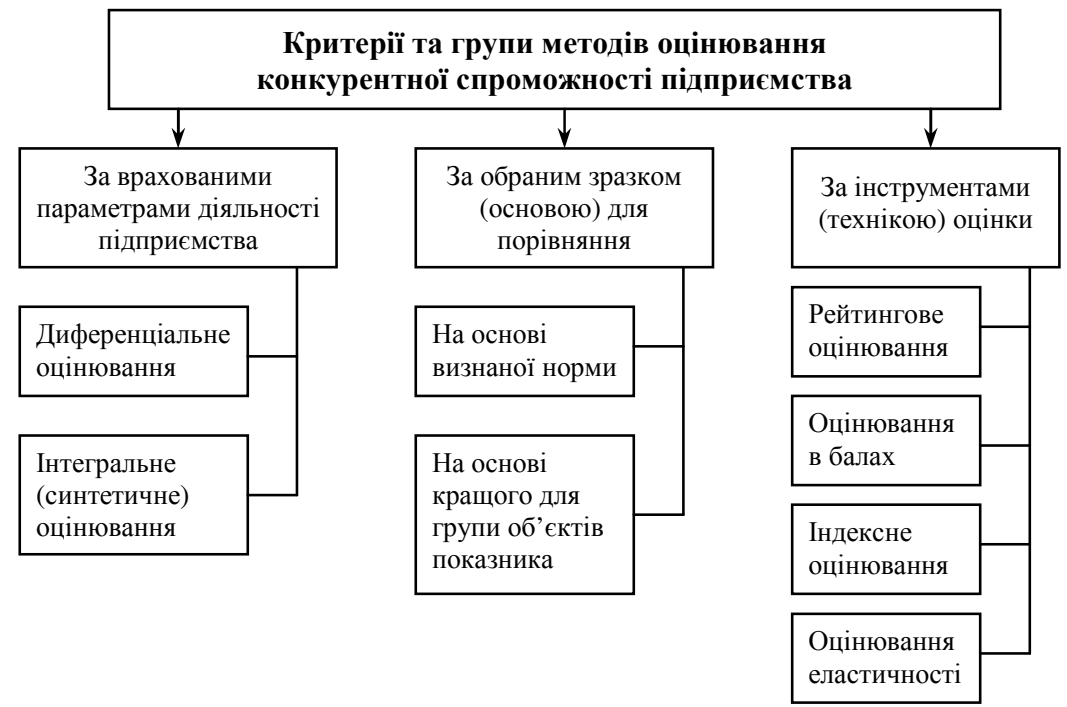

Рис. 4. Критерії та групи методів оцінювання конкурентної спроможності підприємства

Джерело: створено автором самостійно. 
На рис 4. ілюстровано поділ методів оцінювання конкурентної спроможності підприємств за трьома критеріями. За першим критерісм врахованими параметрами діяльності підприємства - виокремлено диференціальні та інтегральні методи. За другим критерієм - обраним зразком - подано методи 3 використанням визнаної норми і 3 використанням кращого показника по групі об'єктів. За третім критерісм - застосованою технікою оцінки - виокремлено методи рейтингового, бального, індексного оцінювання та оцінювання еластичності. Важливо те, що кожний конкретний метод оцінювання конкурентної спроможності підприємства може одночасно належати до декількох груп, відповідаючи декільком критеріям. Це підтверджується аналізом конкретних, застосовуваних в аналізі конкурентної спроможності підприємства методів.

Попри відмінності методів оцінювання конкурентної спроможності підприємства, здебільшого вони грунтуються на ідеї бенчмаркінгу оцінювання (визначення рівня) на підставі порівняння. Оцінювання через порівняння може стосуватися різних боків діяльності підприємства. Насамперед ідеться про порівняння якості продукції, продуктивності, обсягів продажу, ринкової частки, прибутковості інвестицій тощо. Порівняння може стосуватися й таких характеристик, як якість управління, ділова репутація, імідж підприємства. Бенчмаркінг конкурентної спроможності підприємства, як явища дуже мінливого, має відбуватися перманентно. Це вимагає релевантної та постійно оновлюваної інформації про різні боки діяльності підприємства.

Основна складність бенчмаркінгу, як підходу до оцінювання через порівняння конкурентоспроможності, пов'язана з вибором основи для порівняння. Йдеться про вибір аналогів (зразків) - об'єктів 3 параметрами діяльності, які приймаються в якості еталону. Якщо порівнювані підприємства суттєво відрізняються за номенклатурою виробів, технологіями, організацією виробництва та управління, стадією життєвого циклу тощо, то порівняння втрачає коректність. Для уникнення некоректності, «еталонний об’єкт» - гіпотетична компанія, наділена певними властивостями, - має визначатися 3 урахуванням вимоги подібності.

Ідея «еталонного об'єкту» має певні переваги, оскільки створює для підприємства певний позитивний образ в якості мети, яку треба досягти. Водночас, фахівці зі стратегічного управління звертають увагу на негативні результати такого підходу. Адже прагнення підприємств «копіювати модель» може спричиняти деформування економічного суперництва та змагального характеру бізнесу. Наслідком цього може ставатися втрата переваг від правдивого (об'єктивного) суперництва між підприємствами для споживачів і для всієї економіки. 
Типовим прийомом у межах оцінювання через порівняння на основі еталону є експертне оцінювання. Цей прийом може давати позитивні результати у випадку фаховості експертів та правильної статистичної обробки одержаних при опитуванні результатів. Завданням експертів може ставати оцінка рівня якогось параметра (здебільшого того, що не має кількісних показників) у балах, рейтингування досліджуваних об'єктів, значущості впливу (вагових коєфіцієнтів при інтегральному оцінюванні) тощо.

Розгляд окремих методів оцінювання конкурентної спроможності підприємств дає підстави для підтвердження дієвості пропонованої нами класифікації методів оцінювання (рис. 4).

При ототожненні конкурентної спроможності підприємства 3 конкурентною спроможністю створюваних ним товарів використовують диференціальний метод. Тобто, здійснюється порівняння окремих параметрів певного товару та товару, обраного в якості зразка (бази) для порівняння. Таке оцінювання $є$ доцільним для будь-якого етапу життєвого циклу товару й життєвого циклу підприємства. При цьому використовується найпростіша формула відносного оцінювання:

$$
q_{i}=\frac{P_{i}}{P_{i 0}} \times 100 \%,(i=1,2,3, \ldots, n),
$$

де $q_{i}$ - окремий показник конкурентної спроможності підприємства по $i$-му товару, оціненому за певним параметрам, наприклад, за економією електричної енергії при споживанні, за якістю дизайну, за надійністю у користуванні тощо; $P_{i}$ - фактичне кількісне значення параметра, за яким оцінюється товар; $P_{i 0}$ - кількісне значення параметра товару, обраного (визнаного) в якості зразка; $n$ - кількість параметрів, за якими оцінюється товар, через який виявляється рівень конкурентної спроможності підприємства.

Якщо здійснюється оцінювання конкурентної спроможності підприємства через окремі економічні параметри стану підприємства, то також може використовуватися формула 1. В якості параметрів можуть досліджуватися продуктивність, частка ринку, рівень рентабельності, темпи економічного зростання тощо. Змінні моделі матимуть такі значення: $P_{i}$ - фактичне значення параметра, за яким оцінюється економічний стан підприємства; $P_{i 0}-$ кількісне значення економічного параметру підприємства, обраного (визнаного) в якості зразка.

Розглянутий метод оцінювання конкурентної спроможності, за класифікацією, презентованою на рис. 4, належить до групи диференціального оцінювання (за першим критерієм), до групи оцінювання за обраним зразком (за другим критерієм), до групи індексних методів (за третім критерієм). 
Висновки про рівень конкурентної спроможності підприємства, за результатами диференціального (за окремими показниками) оцінювання $є$ достатньо простими. До прикладу, таке оцінювання дає можливість зафіксувати, на скільки відсоткових пунктів параметр товару, за яким оцінюється підприємство, відхиляється від зразка. Але такі прості висновки є обмеженими, бо в них ігнорується багато інших важливих аспектів конкурентної спроможності підприємства.

При врахуванні факту багатосторонності явища конкурентної спроможності підприємства використовуються методи інтегрального (комплексного) оцінювання.

Така інтегральність може бути зреалізована навіть при оцінюванні конкурентної спроможності підприємства через один товар. Комплексність досягається у випадку, якщо товар оцінюється не за одним, а за декількома параметрами. Йдеться про використання так званого параметричного індексу споживчих властивостей товару $\left(J_{n}\right)$ [14], що розраховується за формулою:

$$
J_{n}=\sum a_{j} \times i_{j},
$$

де $n$ - кількість аналізованих параметрів; $a_{j}$ - вага $j$-го параметричного індексу, яка зазвичай визначається експертним шляхом; $i_{j}$ - параметричний індекс $j$-го параметра.

При змішаному диференціально-інтегральному підході, тобто при оцінюванні конкурентної спроможності підприємства через певний товар, який оцінюється не за одним, а за декількома параметрами, може бути застосована формула:

$$
q_{i}=\frac{J_{i}}{J_{i 0}} \times 100 \%,
$$

де $J_{n}$ - параметричний інтегральний індекс оцінювання конкретного товару; $J_{n 0}$ - параметричний інтегральний індекс оцінювання товару, обраного в якості зразка.

Інший варіант інтегрального оцінювання конкурентної спроможності може забезпечуватися при використанні особливого індексу, отриманого без нормування індексів окремих параметрів, за формулою:

$$
I_{n p}=q_{i 1} \times q_{i 2} \times q_{i 3} \ldots q_{i n},
$$

де $I_{n p}$ - груповий показник конкурентоспроможності за нормативними параметрами; $q_{i}$ - окремі індексні показники конкурентоспроможності 3 урахуванням нормативів; $n$ - кількість параметрів, що оцінюються.

Особливість методики оцінювання на основі групового індексу (за формулою 4) полягає в тому, що він передбачає однакову важливість 
для конкурентної спроможності підприємства всіх обраних параметрів. Адже неконкурентність хоча б за одним показником, тобто відсутність певного параметру (до прикладу, $q_{i 2}=0$ ), спричиняє нульове значення всього інтегрального індексу.

Оцінювання конкурентної спроможності 3 використанням формул (2) та (4), за класифікацією, поданою на рис. 4, є інтегральним, на основі визнаної норми та з використанням інтегральних індексів.

Конкурентна спроможність підприємства в усіх досі розглянутих нами методах оцінювалася власне за внутрішніми характеристиками підприємства. Йшлося про якості створених товарів та про різні економічні параметри діяльності. Зовнішній аспект діяльності підприємства при цьому був присутній опосередковано, а саме: при визначенні зразка для порівняння. Однак, конкурентна спроможність може оцінюватися й власне через зовнішні параметри. Зокрема, до таких належать параметри реагування споживачів продукції галузі на зміни в окремих аспектах діяльності підприємства. До таких показників (одночасно методів оцінювати), на наш погляд, можуть належати:

- коєфіцієнти $\left(E_{P}^{D}\right)$ еластичності попиту споживачів $(D)$ за цінами тих товарів, якими насамперед підприємство презентоване на галузевому ринку $(P)$ :

$$
E_{P}^{D}=\frac{\Delta D}{\Delta P} .
$$

Стабільні й відносно невисокі значення цього показника еластичності, на наш погляд, можуть бути потрактовані як свідчення стабільної конкурентної позиції підприємства на ринку;

- показники реагування споживачів на рекламні (іміджеві) заходи підприємства, наприклад, у вигляді коєфіцієнта $\left(k_{A d v}^{\mathrm{Rev}}\right)$ зміни обсягів продажів $(\operatorname{Rev})$ на кожну додаткову одиницю рекламних (іміджевих) витрат $(A d v)$ :

$$
k_{A d v}^{\operatorname{Re} v}=\frac{\Delta \operatorname{Re} v}{\Delta A d v} .
$$

Відносно високі та зростаючі значення цього коєфіцієнта можуть тлумачитися як зміцнення конкурентної позиції через більшу довіру до дій підприємства та до поданої ним інформації;

- коєфіцієнти $\left(k_{\text {Inv }}^{P l}\right)$ зміни позиції підприємства в рейтингу підприємств галузі $(P l)$ на кожну додаткову одиницю звичайних інвестиційних або інноваційних витрат (Inv):

$$
k_{I n v}^{P l}=\frac{\Delta P l}{\Delta I n v} .
$$


Позитивні значення цього коєфіцієнта можуть свідчити про перемогу підприємства у змаганні з іншими підприємствами галузі через більш ефективне інвестування. Останнє $є$ безпосереднім проявом більшої конкурентної спроможності підприємства.

Наведені методи оцінювання конкурентної спроможності підприємства через зовнішнє реагування на зміни в його діяльності фактично, оцінювання еластичності - лише за формою $\epsilon$ диференціальними. За змістом, вони інтегральні. Підставою для такого твердження $є$ те, що зовнішнє оточення галузевого ринку реагує на підприємство як на деяку цілісність. У цій цілісності виявляються переплетіння множини параметрів діяльності підприємства, а не лише якійсь один параметр.

\section{Висновки:}

Досліджені теоретичні підходи до тлумачення змісту конкурентної спроможності підприємства формують підгрунтя для уявлень про зв'язок між конкурентною спроможністю та стабільністю й визначеністю особливої економіки цього підприємства. Але суперечність між стабільністю теперішнього стану підприємства та необхідністю змін заради майбутнього, на якій ми акцентували увагу, ще не «вмонтована» в загальну теорію конкурентної спроможності. Тому наукова і прикладна проблема пояснення зв'язку між конкурентною спроможністю та економічною стабільністю й визначеністю на рівні підприємства навряд чи може вважатися вирішеною.

Аналізовані нами методи оцінювання конкурентної спроможності підприємства, на наш погляд, не містять релевантного прикладного інструментарію оцінювання 3 урахуванням економічної невизначеності. Хоча використовувані в аналізі прийоми дають можливість увести параметр невизначеності в методики оцінювання.

Майбутні дослідження в царині конкурентної спроможності підприємства, на наш погляд, доцільно зосередити на двох проблемах: 1) на уточненні уявлень про зв'язок між здатністю брати участь в економічному змаганні та необхідністю пристосування до умов невизначеності; 2) на створенні методик оцінювання конкурентної спроможності з урахуванням параметру невизначеності.

\section{Лimepamypa:}

1. Про захист економічної конкуренції : Закон України від 11 січня 2001 року №2210. Редакція від 11.08.2013, підстава 406-18. Відомості Верховної Ради Украӥни. 2001. №12. С. 64.

2. Про захист від недобросовісної конкуренції : Закон України від 7 червня 1996 р. №236/96-ВР. Відомості Верховної Ради України. 1996. №36. Ст. 164. 
3. Про застосування спеціальних заходів щодо імпорту в Україну : Закон України від 22 грудня 1998 р. Відомості Верховної Ради Украӥни. 1999. №11. Ст. 78.

4. Рибакова О. В. Конкуренція і конкурентоспроможність: економічна суть та фактори підвищення. URL: http://archive.nbuv.gov.ua.

5. Портер Е. Майкл. Конкурентная стратегия: методика анализа отраслей и конкурентов / Пер. с англ. Москва : Альпина Бизнес Букс, 2005. $454 \mathrm{c}$.

6. Жукевич С. М. Конкурентний аналіз в контексті стратегічного управління підприємством. Економічні науки. Сер. : Економіка та менеджмент. 2012. Вип. 9(2). C. 175-182. URL : http://www.irbis-nbuv. gov.ua/cgi-bin/irbis_nbuv/cgiirbis_64.exe?I21DBN=LINK\&P21DBN= UJRN\&Z21ID $=\& S 21 \mathrm{REF}=10 \& S 21 \mathrm{CNR}=20 \& S 21 \mathrm{STN}=1 \& \mathrm{~S} 21 \mathrm{FMT}=\mathrm{ASP}$ _meta\&C21COM=S\&2_S21P03=FILA=\&2_S21STR=ecnem_2012_9(2)_27.

7. Діденко Є. О., Жураківський П. І. Модель управління конкурентоспроможністю підприємства. Ефективна економіка. 2017. №5. URL : http://www.economy.nayka.com.ua/?op=1\&z=5590.

8. Конкурентоспроможність підприємства: оцінка рівня та напрями підвищення : монографія / За заг. ред. О. Г. Янкового. Одеса : Атлант, 2013. $470 \mathrm{c}$.

9. Castellacci F. Innovation and the competitiveness of industries: Comparing the mainstream and the evolutionary approaches. URL : https://www.sciencedirect.com/science/article/pii/S0040162507001692.

10. Kleynhans E. Factors Determining Industrial Competitiveness And The Role Of Spillovers. The Journal of Applied Business Research. 2016. Volume 32. Number 2. URL : https://clutejournals.com/index.php/ JABR/article/download/9594/9689/.

11. Bakan I., Dogan I. Competitiveness of the industries based on the porter's diamond model: an empirical study. URL : https://www.academia.edu/ 33159606/.

12. Державна інноваційна фінансово-кредитна установа (SFII). URL : www.sfii.gov.ua.

13. Україна в рейтингах: як змінювалися позиції країни в 20142019 роках. URL : https://www.slovoidilo.ua/2019/11/01/infografika/ ekonomika/ukrayina-rejtynhax-yak-zminyuvalysya-pozycziyi-krayiny2014-2019-rokax.

14. Лупак Р. Л., Васильців Т. Г. Конкурентоспроможність підприємства : навч. посіб. Львів : Видавництво ЛКА, 2016. 484 с. 


\title{
РЕЛЕВАНТНА ОЦІНКА НЕРУХОМОГО МАЙНА В МІНІМІЗАЦІЇ ЕКОНОМІЧНОЇ НЕВИЗНАЧЕНОСТІ ПІДПРИЕМНИЦЬКОЇ ДІЯЛЬНОСТІ
}

\author{
Андреєва Віма Анатоліївна, \\ кандидат економічних наук, дочент, \\ дочент кафедри теоретичної та прикладної економіки, \\ ВНЗ Університет економіки та права «КРОК», \\ ORCID: https://orcid.org/0000-0002-6357-3063
}

Анотація. У розділі аналізується проблема релевантної оцінки нерухомого майна в контексті загальної проблеми економічної невизначеності. Автор виходить у своїх міркуваннях про релевантну оцінку з ідеї, що саме така оцінка сприятиме зменшенню зони економічної невизначеності. Здійснено огляд існуючих підходів до оцінки нерухомості з метою акцентування уваги на тих прийомах оцінки, які роблять ії більш досконалим інструментом гарантування економічної стабільності.

Ключові слова: нерухоме майно, ринок нерухомості, оцінка нерухомості, методи оцінки, релевантне оцінювання майна.

Незалежна експертна оцінка майна та майнових прав, яка базується на Національних Стандартах Оцінки, Міжнародних та Європейських Стандартах Оцінки майна та майнових прав, $є$ системним фактором гарантування економічної стабільності. Економічна наука вводить нерухомість у систему свого наукового інтересу, виявляючи в ній специфічні властивості щодо мінімізації економічної невизначеності підприємницької діяльності. На думку економістів, нерухомість $є$ капіталом, поєднаним із землею. Це означає, що цінність та вартість нерухомості обумовлена іiі безпосередньою залежністю від землі. На цьому робили акцент різні дослідники нерухомості $[1 ; 2]$.

Законодавство про оцінку майна $є$ незаперечною інституційною передумовою досягнення вищого рівня визначеності й передбачуваності відносин. Зокрема, Закон України «Про оцінку майна, майнових прав та професійну оціночну діяльність» вимагає певної доведеності результатів оцінки від суб'єктів оціночної діяльності. Оцінка майна, майнових прав - це процес визначення їх вартості на дату оцінки за процедурою, встановленою нормативно-правовими актами з оцінки майна. Він є результатом практичної діяльності суб'єкта оціночної діяльності [3].

Релевантна оцінка нерухомого майна - ознака оцінювання, що зазначена в назві цього розділу - на нашу думку, являє собою рух у бік 
досягнення відповідності між визначеною фахівцями вартістю нерухомого майна та ії дійсною (об’єктивною) ринковою вартістю.

Кожен вид нерухомості має свої особливості функціонування, тому потребує специфічного правового режиму регулювання. Різні види доходу передбачають особливі алгоритми оподаткування. Вони можуть бути пов'язані з частиною вартості нерухомості або з прибутком, що виникає внаслідок функціонування нерухомості.

За критерієм отримання доходу (прибутку), нерухомість, як відомо, поділяється на споживчу, виробничу, комерційну, інвестиційну, дохідну [4].

Споживча нерухомість призначена для постійного (або довготривалого) проживання суб'єктів та розміщення їх власних речей. Ця нерухомість дозволяє користувачам отримувати приховану (альтернативну) ренту. Стосовно саме споживчої нерухомості виникає особливий інституційно-організований суб'єкт володіння - об'єднання власників багатоквартирних будинків, який потрапляє у свій специфічний правовий простір.

Виробнича нерухомість призначена для розміщення різних видів діяльності у сфері промисловості, сільського господарства, транспорту, зв'язку та ін. Дохід від цього виду нерухомості безпосередньо входить у прибуток від основної діяльності. Крім того, певні види виробничої нерухомості (подібно до споживчої) мають приховану ренту, чим обумовлена можливість їх перетворення на комерційну нерухомість.

Комериійна нерухомість призначена для розміщення тих видів господарської діяльності, які безпосередньо пов'язані з наданням послуг споживачам (торговельні приміщення, офіси, кафе тощо). Основна мета розміщення комерційної нерухомості - отримати ренту від місця розташування (де концентрується необхідний рівень купівельної спроможності).

Інвестииійна нерухомість - це всі ті об'єкти (незалежно від призначення), вкладення фінансових ресурсів у які здійснюється 3 метою отримання підприємницького доходу, до складу якого входять прибуток, рента, відсоток. Навколо інвестиційної нерухомості складається багатовимірне економіко-правове середовище. Йдеться про дію механізмів фінансування, іпотечного кредитування. До цього середовища потрапляють операції з цінними паперами, коли фінансування здійснюється шляхом емісії сертифікатів Фонду операцій з нерухомістю.

Функціонування дохідної нерухомості передбачає можливість отримання доходу від передачі об' єктів у різноманітні форми користування. Масштаб операцій з нерухомим майном в Україні постійно зростає. Про це свідчать дані рис. 1 .

Інформація, подана на рис. 1, свідчить про зростання майже у 3 рази за сім років обсягів операцій з нерухомим майном. Це можна інтерпретувати як те, що йдеться про суттєве збільшення привабливості (доходності) цього активу. 


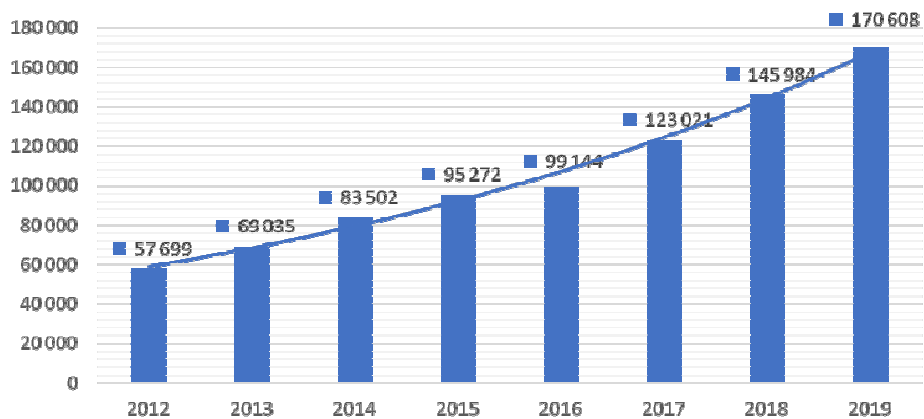

Рис. 1. Операції з нерухомим майном у фактичних цінах, млн грн та їх частка у ВВП, \%

Джерело: власна розробка автора на основі [5].

Користування нерухомістю здійснюється у різноманітних формах. Тільки нерухомості властиві такі особливі форми користування, як:

- фрігольд (користування власником будівлею спільно із землею на необмежений час 3 повною відповідальністю за утримання нерухомості);

- лизгольд (довгострокова оренда з розподілом обов'язків);

- емфітевзис (довгострокова, успадкована оренда сільськогосподарських земель);

- суперфіцій (право забудови землі на необмежений час);

- сервітут (право користування нерухомістю, передане третім особам);

- вертикальний розподіл майнових прав (спеціальні можливості отримання вигоди від підземної частини або повітряного простору).

У сучасних умовах активізується право на придбання обмежених прав на житлові квартири, апартаменти, готельні номери на визначений у договірному порядку проміжок часу (майновий або немайновий таймер). Сьогодні українське законодавство фактично не регулює ці відносини. Вони залишаються у сфері нелегальних відносин, що призводить до різних способів шахрайства.

Формалізований підхід до оцінки ринкової вартості нерухомого майна потребує коректного впровадження для отримання більш доведених результатів, ніж отриманих на основі неформалізованого підходу (суб'єктно-інтуїтивного). Відомі методичні підходи до оцінки нерухомого майна орієнтовані на практичне застосування в умовах стабільної ринкової економіки. Натомість, в Україні такої ринкової стабільності у відносинах немає.

Зазначимо, що сучасні ринкові умови економічної невизначеності створюють для підприємств принципово нові проблеми. Їх вирішення дозволить досягнути та утримати конкурентні позиції на ринку. 
Посилюється усвідомлення того, що розвиток, а отже, і збільшення вартості бізнесу, можливий за рахунок мінімізації економічної невизначеності підприємницької діяльності.

Специфіка вітчизняного ринку нерухомості, який постійно знаходиться в умовах економічної турбулентності, не дозволяє в повній мірі адаптувати відомі міжнародні підходи до оцінки нерухомого майна в реаліях національної економіки. Причинами також є обмеження i недоліки, властиві кожному з класичних підходів до вартісної оцінки майна.

Підходи до оцінки майна розрізняються за своєю спрямованістю та в загальних рисах враховують чинники вартості й практичні аспекти фінансової діяльності, які формуються на основі базової вихідної інформації (табл. 1).

У сфері оцінки нерухомого майна постає питання про узгодження результатів, отриманих за різними підходами для мінімізації економічної невизначеності підприємницької діяльності.

Ситуація на ринку нерухомого майна змушує оцінювачів усе частіше замислюватися про розробку комплексного методу релевантної оцінки нерухомого майна. Йдеться про метод, що враховує різноманітні фактори вартості ще в процесі розрахунків та поєднує переваги кожного 3 класичних підходів. Про це пишуть і теоретики, і практики оціночної справи.

Зважаючи на те, що ефективність оцінки з метою мінімізації економічної невизначеності підприємницької діяльності суттєво залежить від інструментарію іiі проведення, пошук напрямів удосконалення оцінки набуває першочергого значення.

Теоретичним фундаментом методології оцінки майна $є$ системний підхід до визначення основних іiі елементів.

Процес оцінки майна відбувається відповідно до визначеної процедури та за допомогою загальноприйнятих методів оцінки. Таких методів існує декілька. Їх вибір обумовлений насамперед видом об'єкту оцінки та метою, з якою проводиться така оцінка. Для проведення оцінки майна в Україні застосовуються такі основні методичні підходи: дохідний, витратний, порівняльний. Відповідно, дохідний підхід акцентує увагу на доходності, витратний - на активах i зобов'язаннях, порівняльний - на оцінці об'єкта за аналогією з іншими подібними об'єктами.

Оцінка ринкової вартості майна та майнових прав з використанням дохідного підходу базується на визначенні прогнозованого доходу від використання майна. На основі дохідного підходу оцінювач визначає співвідношення майбутніх доходів від об’єкта оцінки та його поточної вартості. До переваг даного підходу насамперед слід віднести його системність.

Сам процес повернення коштів, що були вкладені в об'єкт, може бути як одночасним (наприклад, у момент перепродажу), так і розподіленим 
у часі. Йдеться про те, що основна сума, вкладена в об'єкт, повертається у вигляді періодичних надходжень протягом конкретного проміжку часу.

Таблиия 1

Переваги та недоліки методів оцінки нерухомого майна

\begin{tabular}{|c|c|c|c|}
\hline \multicolumn{2}{|c|}{$\begin{array}{c}\text { Підходи до оцінки нерухомого } \\
\text { майна }\end{array}$} & \multirow[b]{2}{*}{\begin{tabular}{|l|}
\multicolumn{1}{|c|}{ Переваги методу } \\
Використовується для \\
випадків прогнозування \\
постійного за величиною \\
та рівного за періодами \\
прогнозування чистого \\
операційного доходу, \\
отримання якого не \\
обмежено часом \\
\end{tabular}} & \multirow[b]{2}{*}{\begin{tabular}{|l}
\multicolumn{1}{|c}{ Недоліки методу } \\
Оцінка ризиків є достатньо \\
суб'єктивною в Україні. \\
В основі методу \\
знаходиться прогнозування, \\
а не лише фактична \\
інформація про \\
результати діяльності
\end{tabular}} \\
\hline $\begin{array}{l}\text { Дохідний підхід: } \\
\text { передбачає оцінку } \\
\text { вартості, виходячи } \\
3 \text { можливостей } \\
\text { об'єкту приносити } \\
\text { дохід }\end{array}$ & $\begin{array}{l}\text { Метод прямої } \\
\text { (лінійної) } \\
\text { капіталізації }\end{array}$ & & \\
\hline & $\begin{array}{l}\text { Метод непрямої } \\
\text { капіталізації } \\
\text { (дисконтування } \\
\text { грошового } \\
\text { потоку) }\end{array}$ & \begin{tabular}{|l} 
Дозволяє оцінити \\
майбутню доходність \\
об'єкта оцінки та врахувати \\
значення об'єкта на ринку \\
виробництва та реалізації \\
послуг \\
\end{tabular} & $\begin{array}{l}\text { В умовах нестабільної } \\
\text { економіки здійснення } \\
\text { точного прогнозування } \\
\text { потребує високої } \\
\text { кваліфікації оцінювачів }\end{array}$ \\
\hline \multirow{2}{*}{$\begin{array}{l}\text { Витратний } \\
\text { (майновий) підхід: } \\
\text { передбачає оцінку } \\
\text { вартості об'єкту, } \\
\text { виходячи з вартості } \\
\text { його відтворення } \\
\text { (заміщення) в } \\
\text { цінах на дату } \\
\text { оцінки з } \\
\text { подальшим } \\
\text { коригуванням на } \\
\text { суму зносу }\end{array}$} & $\begin{array}{l}\text { Метод прямого } \\
\text { відтворення }\end{array}$ & $\begin{array}{l}\text { Надає можливість } \\
\text { проведення достатньо } \\
\text { точної оцінки витрат, } \\
\text { пов'язаних зі створенням } \\
\text { об'єкта та поелементної } \\
\text { оцінки складових цілісного } \\
\text { об'єкта }\end{array}$ & $\begin{array}{l}\text { Обмежене використання } \\
\text { ринкової інформації } \\
\text { щодо оцінки нерухомого } \\
\text { майна }\end{array}$ \\
\hline & $\begin{array}{l}\text { Метод } \\
\text { заміщення }\end{array}$ & $\begin{array}{l}\text { Має нормативно- } \\
\text { методичну врегульованість } \\
\text { визначення вартості } \\
\text { заміщення з подальшим } \\
\text { вирахуванням суми } \\
\text { зносу (знецінення) }\end{array}$ & $\begin{array}{l}\text { Трудомісткість оцінки } \\
\text { об'єктів з більшим } \\
\text { терміном служби через } \\
\text { складність визначення } \\
\text { зносу }\end{array}$ \\
\hline \multirow[t]{2}{*}{$\begin{array}{l}\text { Порівняльний } \\
\text { (підхід аналогів } \\
\text { продажу): } \\
\text { базується на } \\
\text { оцінці вартості } \\
\text { об'єкта, виходячи } \\
\text { з вартостей } \\
\text { аналогічних } \\
\text { об'єктів }\end{array}$} & $\begin{array}{l}\text { Метод } \\
\text { галузевих } \\
\text { коєфіцієнтів }\end{array}$ & $\begin{array}{l}\text { Відображає фактично } \\
\text { досягнуті результати } \\
\text { експлуатації об'єктів. } \\
\text { Визначає ціну об'єкта на } \\
\text { основі фактичної ціни } \\
\text { купівлі-продажу } \\
\text { аналогічних об'єктів } 3 \\
\text { урахуванням корегувань } \\
\text { щодо їх співставлення }\end{array}$ & $\begin{array}{l}\text { Ігнорування перспектив } \\
\text { розвитку об'єкта в } \\
\text { майбутньому. } \\
\text { Трудомісткий збір повної } \\
\text { та достовірної інформації. } \\
\text { Складні коректування в } \\
\text { процесі нівелювання } \\
\text { відмінностей об'єкта } \\
\text { оцінки }\end{array}$ \\
\hline & Метод аналогів & $\begin{array}{l}\text { Можливість залучення } \\
\text { апарата математичної } \\
\text { статистики та } \\
\text { комп’ютерного } \\
\text { моделювання }\end{array}$ & $\begin{array}{l}\text { Неможливо використову- } \\
\text { вати, якщо немає } \\
\text { інформації з угод купівлі- } \\
\text { продажу фірм-аналогів } \\
\text { або якщо нерозвинений } \\
\text { ринок купівлі-продажу } \\
\text { підприємств }\end{array}$ \\
\hline
\end{tabular}

Джерело: власна розробка автора на основі [6-8]. 
Фундаментальним для доходного підходу є принцип очікування. Адже саме відповідно до принципу очікування вартість майна визначається дійсною (теперішньою, поточною) цінністю всіх його майбутніх доходів. Логічним виглядає твердження про те, що чим вищий дохідний потенціал оцінюваного майна, тим більша його вартість. При цьому варто пам'ятати лише, що аналіз доходів повинен здійснюватися протягом усього подальшого економічного життя об'єкта оцінки за умови його використання протягом цього періоду часу найбільш ефективним чином.

У відповідності з принципом заміщення максимальна вартість оцінюваного майна не повинна перевищувати найменшу ціну, за якою може бути придбане інше аналогічне майно з еквівалентною дохідністю. Даний принцип за своєю сутністю $є$ аналогом економічного принципу альтернативності інвестицій. Можна стверджувати, що у випадку, коли оцінювач може 3 достатньою точністю спрогнозувати майбутні доходи власника від майна, яке $є$ об'єктом оцінки, протягом конкретно визначеного часу, використання дохідного підходу оцінки є цілком доцільним, а у більшості випадків і абсолютно незамінним.

Основними прийомами даного підходу є:

- метод капіталізації чистого доходу. На його основі визначається потік доходу з перетворенням його в поточну вартість на основі норм капіталізації:

$$
V=\frac{I}{R},
$$

де $V$ - вартість бізнесу; $I$ - чистий дохід; $R$ - норма доходу.

Проте даний метод може дати об'єктивну оцінку винятково в умовах стабільної економіки, за який об'єкт оцінки, наприклад, підприємство протягом тривалого періоду отримувало стабільний дохід;

- метод дисконтування грошового потоку (метод непрямої капіталізації) дає змогу вирахувати поточну вартість майбутніх доходів. Спосіб отримання доходу при цьому значення не має, він може бути отриманий як від володіння самим майном, так і від реалізації майна. Ідеологія методу дисконтованих грошових потоків полягає у тому, що розсудливий інвестор оцінює своє майно 3 погляду доходу таким чином: як можливий дохід, отриманий від експлуатації майна (за період); як реверсію - дохід від об'єкта оцінки, пов'язаний з його продажем у післяпрогнозний період. Це означає, що поточну вартість майна можна розрахувати за формулою [9]:

$$
P V=\frac{I_{1}+R_{1}}{1+i},
$$


де $I_{1}$ - дохід, отриманий від експлуатації майна в кінці першого періоду; $R_{1}$ - реверсія (вартість майна) в кінці першого періоду; $P V-$ поточна вартість майна; $i$ - ставка дисконту (норма доходу на капітал).

Український учений-практик С. Й. Максимов, досліджуючи методи визначення вартості банку, слушно зауважує, що використання дохідного підходу дозволяє найбільш повно врахувати цільові установки діяльності банків, узгоджені з параметрами економічного і соціального розвитку країни загалом та банківської системи зокрема [9].

Деякі зарубіжні вчені вважають, що метод непрямої капіталізації $\epsilon$ найбільш універсальним і достовірним методом оцінювання вартості підприємства. При цьому вчені зазначають, що такий метод найкраще відображає ринкову вартість підприємства. Йдеться про те, що вартість підприємства можна достовірно оцінити лише тоді, коли буде розраховано дохід, який генеруватиметься підприємством у майбутніх періодах [10].

Ми погоджуємося 3 твердженням Т. Коупленда про те, що даний метод не може врахувати низку об'єктивних чинників щодо оцінки майна: інфляцію, коливання курсу валют, інші форс-мажорні обставини. Крім того, джерельною базою для такого методу виступають фінансова та бухгалтерська звітність, дані маркетингового дослідження, стратегія розвитку, перспективні плани тощо. Ця база теж не може гарантувати об'єктивності в проведенні оцінки, адже важко в умовах економічної невизначеності спрогнозувати майбутню вартість готової продукції, устаткування, сировини тощо [11].

Метод дисконтування грошового потоку буде ефективним для застосування щодо підприємств, майнових комплексів, що розвиваються ефективно, характеризуються стабільним доходом, мають довготривалу історію свого функціонування. Він потребує значної кількості коригувань для доведення прогнозованої структури фінансування до реального значення вартості підприємства.

На думку Л. А. Лейфера, практичне застосування методів дисконтування вільних грошових потоків для підприємства, для акціонерного капіталу та активів повинно давати однаковий узагальнюючий показник вартості підприємства [12]. Дані методи дають однакові результати після врахування таких умов:

- в якості вартості акціонерного капіталу та боргів приймається їх ринкова вартість;

- співвідношення між складовими капіталу компанії має бути постійним протягом усього періоду оцінювання;

- темп зростання доходів дорівнює нулю.

Таке твердження може бути адаптоване й до інших сфер господарської діяльності. Але при цьому не вирішується основна проблема - точність розрахунку майбутніх доходів. 
На основі витратного (майнового) підходу переважно відбувається оцінка нерухомого майна, ринок обігу якого $є$ обмеженим (заклади освіти, культури, пам'ятки архітектури тощо).

Для оцінки об'єктів нерухомого майна витратний підхід застосовується за умови необхідності заміщення такого майна чи визначення їхньої економічної доцільності.

Застосування витратного підходу є доцільним за необхідності [13]:

- проведення оцінки державних об'єктів;

- встановлення вартості майна спеціального призначення (школи, лікарні, архітектурні та культурні будівлі, вокзали, відділення зв'язку тощо);

- проведення бухгалтерського обліку;

- встановлення об'єкта оподаткування;

- виставлення майна на аукціон чи інші відкриті торги.

Особливістю такого підходу є проведення оцінки майна винятково на основі аналізу наявних активів. 3 одного боку, це $\epsilon$ перевагою даного методу, адже його результати значною мірою одержано на об'єктивній основі, з іншого боку, даний підхід не враховує перспективи розвитку бізнесу на основі аналізу основних фінансово-економічних показників. Це робить даний метод більш статичним. Він дозволяє визначити нижчий рівень вартості підприємства, майнового комплексу загалом або окремої його частини.

Витратний підхід базується на припущенні, що типовий покупець не запропонує за об'єкт нерухомості кошти більші, ніж сума грошей, яку треба витратити на купівлю земельної ділянки та будівництво на ній об'єкта, аналогічного за своїми споживчими характеристиками нерухомості, що оцінюється.

Розрахунок вартості будівель та споруд у більшості випадків виконується із застосуванням методу оцінки за вартістю одиничного показника, поширеного у вітчизняній оціночній практиці. Однак, необхідно мати на увазі, що він дає розбіжність у 15-20\%. Даний метод грунтується на порівнянні вартості одиниці споживчих властивостей нерухомості (1 м² жилої площі, 1 м $^{3}$ будівельного об'єму і т.п.) оцінюваного об'єкта 3 вартістю аналогічної одиниці виміру подібного типового спорудження.

Задача оцінки полягає в розрахунку залишкової вартості, що являє собою відновну вартість, зменшену на величину зносу. При цьому відновна вартість визначається на основі вартості одиничного показника об'єкта-аналога, а знос, - виходячи з фізичного зносу кожного елемента будівлі, що оцінюється.

Розрахунок здійснюється у такій послідовності:

1.Вибір будівельного аналога.

2. Оцінка вартості об'єкта в цінах, приведених в «Укрупнених показниках відновної вартості» (УПВВ).

3. Визначення відновної вартості. 
4. Розрахунок залишкової відновної вартості.

Вибір аналога здійснюється за допомогою «Укрупнених показників відновної вартості». Вони згруповані в збірниках за галузями народного господарства або за видами будівель і споруд, які містять відновну вартість $1 \mathrm{~m}^{3}$ будівельного об'єму будівлі, 1 км трубопроводу або

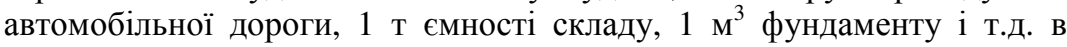
залежності від призначення, конструкції, капітальності, благоустрою, розміру й розташування у визначеному територіальному поясі (для України 2 пояс) з урахуванням кліматичного району.

При визначенні відновної вартості будівлі оціночна вартість одиниці укрупненого вимірника, прийнята за відповідним збірником Укрупнених показників відновної вартості будівель і споруд для 2-го територіального поясу, збільшується на загальну кількість одиниць виміру об'єкта оцінки.

Вартість об' єкта оцінки $\left(V_{\text {repl }}\right)$ при використанні методу розрахунку за вартістю одиничного показника $\left(V_{u n}\right)$ визначається за формулою:

$$
V_{\text {repl }}=V_{\text {un }} \times S(V),
$$

де $V_{\text {repl }}$ - відновна вартість об' єкта оцінки в цінах; $V_{u n}$ - базова вартість одиничного показника відповідно до збірників УПВВ, грн; $S(V)-$ загальна площа (будівельний об'єм) об'єкта оцінки, м $^{2}, \mathrm{~m}^{3}$.

Відновна вартість на дату оцінки не враховує ступеня фізичного зносу і визначається таким чином [6]:

$$
V_{\text {repl.date }}=V_{\text {repl }} \times K_{n},
$$

де $V_{\text {repl.date }}$ - відновна вартість на дату оцінки, грн; $V_{\text {repl }}$ - відновна вартість об'єкта оцінки, грн; $K_{n}-$ інтегральний індекс збільшення вартості будівництва з 1969 р. до дати оцінки.

$$
K_{n}=K_{\text {inc }} \times K_{\text {app }} \times K_{\text {inf }},
$$

де $K_{\text {inc }}$ - коєфіцієнт, який враховує збільшення вартості будівництва; $K_{a p p}$ - ринковий коєфіцієнт подорожчання вартості будівельно-монтажних робіт на території України; $K_{\text {inf }}-$ коєфіцієнт інфляції.

Коєфіцієнт подорожчання $\left(K_{\text {inc }}\right)$ враховує збільшення вартості будівництва і розраховується перемноженням галузевого індексу на територіальний коєфіцієнт.

Ринковий коєфіцієнт подорожчання $\left(K_{\text {app }}\right)$ характеризує зміну вартості будівельно-монтажних робіт. Коєфіцієнт розраховується 3 урахуванням даних Держкомстату України і публікується в збірнику офіційних документів та роз'яснень Державного комітету будівництва і житлової політики України «Ціноутворення в будівництві».

Коєфіцієнт інфляції $\left(K_{\mathrm{inf}}\right)$ використовується у випадку, якщо дата оцінки відрізняється від дати, на яку опублікований ринковий коєфіцієнт 
подорожчання вартості будівельно-монтажних робіт на території України. Він розраховується Держкомстатом України і публікується в періодичній пресі за підсумками кожного місяця.

Визначивши відновну вартість об'єкта, отримуємо його залишкову відновну вартість, яка зменшується на величину зносу та розраховується за формулою [6]:

$$
V_{\text {res }}=V_{\text {repl.date }} \times K_{\text {wear }},
$$

де $V_{\text {res }}$ - залишкова вартість об'єкта, грн; $V_{\text {repl.date }}$ - відновна вартість на дату оцінки, грн; $K_{\text {wear }}-$ коєфіцієнт фізичного зносу.

Величину фізичного зносу характеризує коєфіцієнт фізичного зносу об' єкта, що визначається таким чином:

$$
K_{\text {wear }}=1-\frac{W}{100},
$$

де $K_{\text {wear }}$ - коєфіцієнт фізичного зносу, од.; $W$ - фізичний знос будівлі, \%.

$$
W=\sum_{i=1}^{I} F_{i},
$$

де $F_{i}$ - середньозважений знос елемента будівлі (фундамент, стіни, перекриття і т. ін.).

$$
F_{i}=f_{i} \times l_{i},
$$

де $f_{i}$ - відсоток зносу елемента будинку в залежності від технічного стану; $l_{i}$ - питома вага вартості елемента у вартості всього об'єкта.

Визначення фізичного зносу об'єкта оцінки робиться на базі огляду стану його конструктивних елементів у відповідності до Правил оцінки фізичного зносу жилих будинків, затверджених Держкомітетом 3 житлово-комунального господарства №52 від 02.07.1993 p.

Також, при розрахунках вартості методом витрат необхідною умовою $\epsilon$ врахування вартості земельного компоненту, тобто врахування права користування земельною ділянкою.

Даний підхід дає найбільш достовірні результати, коли оцінюються об'єкти незавершеного будівництва, спеціалізованої нерухомості, а також при оцінці інфраструктури. Менш достовірні результати - при застосуванні цього підходу до оцінки вбудованих приміщень.

Порівняльний підхід у процесі оцінки майна дозволяє зіставити вартість об'єкта оцінки з витратами на придбання аналогічного чи схожого об’єкта. Проте, очевидним є недолік такого методу - пошук аналогічного об'єкта. Це стосується оцінки майна великих промислових комплексів, унікальних споруд, їх територіального розміщення тощо.

У рамках порівняльного підходу (аналогів продажу) дійсне припущення, що дані за угодами, що вже відбулися, є результатом 
суджень продавців та покупців стосовно вартості об'єктів. Вони включають у себе інформацію, яка дозволяє приймати рішення про ринкову вартість об'єкта. В основі підходу лежить принцип заміщення, згідно з яким типовий покупець не сплатить за виставлений на ринку нерухомості об'єкт ціну, більшу ніж витрати на купівлю іншого об'єкта з однаковою корисністю.

У загальному вигляді метод ринкового порівняння (метод аналогів продажу) формалізується таким чином [14]:

$$
V_{o b}=V_{a n} \times K_{\text {diff }},
$$

де $V_{o b}$ - вартість об'єкта оцінки, грн; $V_{a n}-$ вартість аналога, грн; $K_{d i f f}-$ коєфіцієнт, який враховує відмінність об'єкта оцінки від об'єкта-аналога.

Після вибору одиниці порівняння визначаються основні показники або елементи порівняння, використовуючи які можна змоделювати вартість об'єкта оцінки за допомогою необхідних коригувань цін продажу об'єктів-аналогів.

Виходячи з цього, формулюється основне правило коригування при реалізації методу порівняння продажів: коригується ціна продажу об’єкта-аналога для моделювання вартості об'єкта оцінки [15].

Виділяють такі основні елементи порівняння:

- права власності на об'єкт оцінки, що передаються $\left(K_{\text {own }}\right)$. Наявність тих або тих обмежень на право власності об'єктивно знижує вартість об'єкта оцінки, а отже, і ціну продажу;

- умови продажу (вільний продаж, примусовий продаж) $\left(K_{\text {terms }}\right)$. Даний елемент порівняння дозволяє виключити об'єкти порівняння 3 ряду аналогів або провести за ними коректування цін продажів при виявленні відхилень від ринкових умов продажу, зумовлюваних нетиповою мотивацією придбання майна;

- умови фінансових розрахунків при придбанні того або того активу $\left(K_{\text {calc }}\right)$ - угоди купівлі-продажу в аспекті фінансових розрахунків можуть мати різноманітні варіанти, з яких можна виділити два типових:

a) розрахунок покупця з продавцем за рахунок власних коштів i на дату продажу;

б) фінансування угоди купівлі-продажу об'єкта нерухомості самим продавцем, тобто надання ним покупцеві комерційного кредиту (відстрочка платежу);

- динаміка угод на ринку $\left(K_{d y n}\right)$. Цей елемент порівняння дозволяє виявити вплив фактору часу в широкому контексті на динаміку угод на ринку нерухомості й, відповідно, на рівень цін продажів. Складовою фактору часу є інфляція або дефляція, зміни в законодавстві щодо прав власності, оподатковування, зміна попиту та пропозиції на об'єкти нерухомості й інше; 
- місцерозташування $\left(K_{l o c}\right)$. Територіальні координати розміщення того або того об'єкта нерухомості при визначенні його вартості трансформуються в рентну складову вартості. Наприклад, вартість нерухомості залежить від багатьох характеристик, пов'язаних з місцем його розташування, а саме: розбіжності в розташуванні земельних ділянок у різних природнокліматичних зонах, у населених пунктах різних категорій і в межах населених пунктів у різних функціональних й економікопланувальних зонах;

- фізичні характеристики $\left(K_{p h . c h}\right)$ визначають корисність (а отже, і вартість) самого об'єкта оцінки. Перелік фізичних характеристик різноманітні - вік та стан, вид використаних будівельних матеріалів, розмір і форма земельної ділянки (для об’єктів нерухомості), архітектура будинків або спорудження й дизайнерське оформлення інших видів активів та інше.

Таким чином, коєфіцієнт, що характеризує відмінність об'єкта оцінки від об'єкта-аналога можна розрахувати за такою формулою [15]:

$$
K_{\text {diff }}=K_{\text {own }} \times K_{\text {calc }} \times K_{\text {terms }} \times K_{\text {dyn }} \times K_{\text {loc }} \times K_{\text {ph.ch }} .
$$

Даний підхід застосовується, коли $є$ інформація про продаж об'єктів з аналогічними до об'єкта оцінки характеристиками. Враховуючи те, що як первинний, так і вторинний ринки нерухомості на даний час уже сформовано та достатньо інформації про ціни пропозицій аналогів, даний метод визначення вартості $\epsilon$ найбільш достовірним.

Порівняльний підхід реалізується на основі застосування таких методів:

- метод галузевих коєфіцієнтів. Застосування даного методу буде ефективним у випадку системного підходу до його використання. Потрібно вивчити статистичні дані, а також аналітичні узагальнення щодо основних виробничо-фінансових показників підприємства;

- метод компанії-аналога будується на основних засадах бенчмаркінгу і дозволяє на основі вивчення досвіду діяльності аналогічної компанії чи компанії, яка досягла значних успіхів, визначити скоректовану ціну підприємства. Ефективність застосування такого методу залежить від низки чинників: аналог має належати до тієї ж галузі, наближено відповідати за формою управління, географією розташування, видом діяльності, правовою та організаційною структурою, часом функціонування, обсягом виробництва; кількістю працюючих тощо.

Зазначимо, що в міжнародній практиці існує низка методологічних підходів до оцінки нерухомого майна, які в адаптованому вигляді можуть бути імплементовані у вітчизняну практику. Йдеться про модель Едвардса-Белла-Ольсона, (ЕВО) [16]:

$$
V=B_{0}+\sum_{t=1}^{T} \frac{E\left[\Delta X_{t}\right]}{(1+r)^{t^{\prime}}},
$$


де $B_{0}$ - власний капітал (чисті активи) компанії на момент; $E$ - символ математичного очікування; $r$ - ставка дисконтування, яка відповідає очікуваній вартості обслуговуваного капіталу; $\Delta X_{t}-$ відхилення чистого прибутку на момент $\mathrm{t}$ від «норми» (надприбуток).

Модель належить до так званих моделей «залишкового» доходу (Redial Income Model) або RIM. Вважаємо, що модель Ольсона, як одна із перспективних розробок у теорії оцінки майна, синтезує окремі переваги дохідного і витратного підходів. Вона навіть мінімізує недоліки кожного з них, адже оцінка майна відбувається на основі комплексного застосування таких показників:

- балансової вартості в статистичному розрізі за певний період на основі ринкових даних;

- ставки дисконтування;

- величини сплачених дивідендів;

- емпіричних параметрів, значення яких встановлюються за даними всього ринку.

Проте, застосування такої моделі в українських реаліях буде ускладнено низкою проблем, адже дані бухгалтерської звітності вітчизняних компаній переважно не відповідають ринковій вартості. До того ж, можна припустити, що в основі даної моделі закладена постійність волатильності. Це теж ускладнює застосування даних методик в стані економічної невизначеності підприємницької діяльності в Україні.

Отже, можемо зробити припущення, що в даний час немає відповідної методики оцінки майна, апробованої зарубіжним досвідом, яка б забезпечила об'єктивність проведення оцінки нерухомого майна в національних економічних реаліях. Ті методи, підходи, моделі, що $\epsilon$ ефективними в умовах дії міжнародних економічних систем, виявляються не пристосованими до економічних умов в Україні.

Вважаємо, що існує необхідність доповнення національних методичних підходів вимогами щодо збільшення кількості об'єктивної інформації при оцінці нерухомого майна. Наша пропозиція грунтується на власних спостереженнях про відсутність на всіх етапах оцінки як нерухомого майна, так і цілісних майнових комплексів, результатів інтелектуальності власності та інших об'єктів оцінки, об'єктивної, достовірної, своєчасної, цінної, повної інформації про об'єкт оцінки.

У даному контексті ми цілком підтримуємо думку українського вченого-практика С. Й. Максимова, що в умовах інноваційної економіки й швидкого оновлення бізнес-процесів виникає необхідність розкриття у фінансовій звітності інформації щодо стратегії розвитку компанії, яка спрямована на зростання вартості бізнесу і зміцнення його конкурентної переваги. Надання зацікавленим сторонам широкого спектру інформації позитивно позначиться на ринковій капіталізації компаній. 
Безумовно, практичне втілення концепції інформатизації, релевантної оцінки нерухомого майна потребує значних зусиль, насамперед - це формування інформаційних масивів відкритого доступу про об'єкт оцінки. Проте, за умови успішної реалізації та практичного застосування такого підходу, ми зможемо максимально мінімізувати корупційну складову у процесі релевантної оцінка нерухомого майна та дати можливість застосування апробованих міжнародною практикою методів оцінки майна.

Наша пропозиція виходить також із визначених нами основних проблем, 3 якими стикаються на практиці українські оцінювачі. 3 метою мінімізації невизначеності підприємницької діяльності необхідно: по-перше, відкрити інформацію про перспективи розвитку населених пунктів, яка $є$ категорією з обмеженим доступом, як правило, службовою інформацією. По-друге, доцільно систематизувати дані про угоди (маємо на увазі угоди купівлі-продажу). По-третє, необхідно аналогові бази даних про ринкову вартість майна тощо.

Інформаційний підхід в оцінці майна передбачає сукупність певним чином організованих даних про результати господарської діяльності, про різні аспекти, що характеризують функціонування виробничого об' єкта.

Джерельна база інформаційного підходу формується з планових, нормативних, облікових, звітних даних та аналітичної інформації. У структурі інформаційного масиву виділяються відомості про фактичні результати господарської діяльності й про показники в якості бази порівняння.

На основі інформаційного підходу можуть розроблятися матриці SWOT-аналізу, що дозволить спростити процедуру побудови оцінки й забезпечить наочність проведених операцій. Окрім того, важливим джерелом інформації в контексті інформаційного підходу в оцінці майна можуть слугувати геоінформаційні системи (ГІС). На сьогоднішній день мало знайдеться компаній, які не потребували б технологій ГІС. Адже тільки за допомогою цієї системи можливо в найкоротші терміни обробити значну кількість інформації.

Цікавим у розрізі нашого дослідження є досвід Словенії, де 3 використання кредиту Міжнародного банку реконструкції та розвитку, розроблено і впроваджено в дію «Геоінформаційний план підтримки менеджменту нерухомості». Глобальною метою даного проєкту $\epsilon$ забезпечення оперативною підтримкою менеджмент та економіку сектору нерухомості для зміцнення міжнародних зв'язків i використання інформаційних баз даних (земельних реєстрів тощо) та інструментарію, що належить до сучасних інформаційних технологій. Сама методологія у всьому, що стосується збору даних, спроєктована на двох рівнях: дані збираються як на державному рівні, так і на місцевому. 
Але в оцінці майна потрібні не тільки дані з вихідних баз, надані геоінформаційним центром, необхідні також і результати аналізу ринку нерухомості. Оцінка майна 3 використанням ГІС дозволить отримувати наочну інформацію за напрямками нового будівництва, про щільність існуючої забудови міста, з'явиться можливість якісного та кількісного зонування на ринку нерухомості, відображення ділянки на карті міста i конкурентного середовища поблизу нього. Саме геоінформаційні технології дають можливість об'єднати між собою різні види інформації - статистичної, економічної тощо та географічну основу об'єктів. Адже для аналітичної діяльності цифр таблиць буває недостатньо. Тільки поєднання можливостей ГІС і накопиченої оцінювачем аналітичної інформації дає можливість мати повну картину щодо об'єкта оцінки.

Розвиток ринку нерухомості породжує нову трансакційну послугу, яка реалізується завдяки діяльності професійних сервейінгових фірм. Основна функція сервейінгів - забезпечити комплексний підхід до управління нерухомістю на основі розмежування функцій власника (прийняття стратегічного рішення, контроль за якістю) й управлінця (розробка конкретних дій маркетингових досліджень, консультування, інвестування та їх оперативне виконання 3 метою досягнення ефективного результату для власника і суспільства).

\section{Висновки:}

Оцінка нерухомого майна, як процедура зі значним стабілізуючим потенціалом, може використовуватися для обмеження масштабів економічної невизначеності. Саме таку оцінку нерухомого майна можна вважати релевантною для умов національних економік з високим рівнем невизначеності. Саме такою є українська економіка.

Застосовувані у практиці інших країн та в Україні підходи й методики оцінювання нерухомого майна містять окремі елементи, які, у випадку їх реалізації, робитимуть оцінку релевантною. Йдеться про відповідність оцінки тим конкретним умовам, в яких використовується, купується та продається нерухоме майно. Попри важливість загальних підходів до оцінки нерухомого майна, що випливають 3 економічної природи нерухомості, в методиках національної оцінки мають враховуватися й особливі умови.

\section{Лimepamypa:}

1. Маркус I. Я. Посібник з оцінки бізнесу в Україні : навчальний посібник. Київ : Міленіум, 2002. 320 с.

2. Фридман Дж., Ордуэй Н. Анализ и оценка приносящей доход недвижимости. Москва : «Дело Ltd.», 2005. 480 с.

3. Про оцінку майна, майнових прав та професійну оціночну діяльність в Україні : Закон України від 12.07.2001 №2658-III. URL : 
zakon.rada.gov.ua/laws/show/2658-14.

4. Платонов Б. О. Основи оціночної діяльності: навчальний посібник. Київ : НАКККіМ, 2013. 227 с.

5. Офіційний сайт Державної служби статистики України. Основні економічні показники короткострокової статистики будівництва. URL : www.ukrstat.gov.ua.

6. Національний стандарт №1. Загальні засади оцінки майна і майнових прав. URL : zakon.rada.gov.ua/laws/show/1440-2003-п.

7. Національний стандарт №4. Оцінка майнових прав інтелектуальної власності. URL : zakon.rada.gov.ua/go/1185-2007-п.

8. Драпіковський О. І., Іванова I. Б. Оцінка нерухомого майна: дві техніки дохідного підходу. URL : http://irbis-nbuv.gov.ua/cgibin/irbis_nbuv/cgiirbis_64.exe?C21COM=2\&I21DBN=UJRN\&P21DBN= UJRN\&IMAGE_FILE_DOWNLOAD=1\&Image_file_name=PDF/MTP_2 015_58_24.pdf.

9. Максимов С. Й. Оцінка майна для застави та реалізації банківськими установами: навчальний посібник. Київ : Всеукраїнська асоціація фахівців оцінки, 2017. 112 с.

10. Чубка О. М., Федевич Л. С., Курило О. Б. Витратний підхід до оцінки вартості підприємства: характеристика методів. URL : http://economyandsociety.in.ua/journal/19_ukr/179.pdf.

11. Коупленд Т., Коллер Т., Муррин Д. Стоимость компаний. Оиенка и управление. 2005. 360 с.

12. Лейфер Л. А. Точность результатов оценки и пределы ответственности оценщика. URL : http://www.labrate.ru/leifer/lev_leifer_ accuracy_and_appraiser-s_liability-2009-1.htm.

13. Безкоровайна Л. В. Проблеми ідентифікації та оцінки нематеріальних активів. URL : http://visnyk-onu.od.ua/journal/2019_24_ 1/24.pdf.

14. Pagourtzi E., Assimakopoulos V., Hatzichristos T., French N. Real estate appraisal: a review of valuation methods. Journal of Property Investment and Finance. URL : https://www.emerald.com/insight/content/ doi/10.1108/14635780310483656/full/html.

15. Lentovo W., Williams M. Fundamentals of Real Estate Appraisal. URL : https://books.google.com.ua/books?hl=uk\&lr=\&id=3dtj1ymz5EC\&oi=fnd\&pg=PR9\&dq=real+estate+appraisal\&ots=hoom-9SJ81\&sig= rtpdaLw183AWsyPYyNUdPuxoCXY\&redir_esc=y\#v=onepage $\& \mathrm{q}=\mathrm{real} \% 2$ 0estate\%20appraisal\&f=false.

16. Ордов К. В. Использование модели Ольсона для экспрессоценки стоимости компаний. URL : https://www.elibrary.ru/item.asp?id= 26302751. 


\title{
КОМПАРАТИВНИЙ АНАЛІЗ ПОДАТКОВОГО ЗАБЕЗПЕЧЕННЯ ЕКОНОМІЧНОЇ СТАБІЛЬНОСТІ ТА ВИЗНАЧЕНОСТІ: УКРАЇНА VS НIМЕЧЧИНА
}

\author{
Потапенко Денис Олександрович, \\ кандидат економічних наук, \\ дочент кафедри теоретичної та прикладної економіки, \\ ВН3 «Університет економіки та права «КРОК», \\ ORCID: https://orcid.org/0000-0002-4401-9243,
}

Троц Ірина Вікторівна, кандидат економічних наук, дочент кафедри теоретичної та прикладної економіки, ВН3 «Університет економіки та права «КРОК», ORCID: https://orcid.org/0000-0001-9608-0591

Aнотація. Податки можуть ставати визначальним інструментів впливу на стабільність та визначеність національної економіки. Але за одних умов вони стабілізують, а за інших, навпаки, - руйнують стабільність. У цьому розділі, спираючись на порівняння двох національних моделей оподаткування - успішної німецької та неуспішної української автори намагаються зробити певні узагальнення. Вони стосуються відповідей на питання: у який спосіб можна через податкову систему створювати умови стабільної економічної діяльності та обмежувати економічну невизначеність.

Ключові слова: податкова система, податкове навантаження, податковий тягар, податкові пільги та субсидії, податкова стабільність.

Актуальність теми впливу на стабільність економіки через систему оподаткування є незаперечною. Суб'єкти української економіки зазнають різні суперечливі впливи від фінансових установ, які не виконують функцій доступного кредитування, від монетарної сфери 3 іiі змінами курсу національної валюти, від судової системи, яка не захищає права власності тощо. Але найбільш суттєвий вплив на економічну діяльність усе ж справляють податки. Під «податковим забезпеченням стабільності економіки» маємо на увазі не лише сукупність певних видів податків та податкових ставок. Ідеться про способи стягнення податків, пріоритети органів податкової влади, незмінність і прозорість правил стягнення податків тощо.

За майже 30 років існування новітньої Української держави податкова система зазнавала перманентних змін. Але попри ці зміни, здійснювані під «благородними політичними гаслами», податкові органи, здебільшого, виконували фіскальні та каральні функції. Натомість, 
український бізнес потребував стимулюючих, консультативних функцій та функцій упорядкування. Брак останніх підривав стабільність економіки й продовжує стримувати їі розвиток на початку 2020-х рр. У період найважчої, за масштабами згортання українського бізнесу, економічної кризи 2019 - 2020 рр. реформування податкової системи набуває ще більшої ваги. Метою цього реформування, на думку авторів розділу, має стати передусім порятунок українського малого та середнього бізнесу, стимулювання сукупного попиту споживачів. Тому порівняння української практики оподаткування з практикою найбільш розвиненої країни Свропейського Союзу - Німеччини може сприяти обгрунтуванню раціональних і доцільних рішень у сфері публічного управління.

Вплив податків на стабільність економіки є предметом багатьох досліджень аналітиків 3 різних країн $[1 ; 2]$. Вплив податкового навантаження на розвиток бізнесу аналізується й українськими дослідниками [3; 4].

Ми робимо припущення про існування такого алгоритму переходу імпульсу від податкової системи до економічної стабільності та економічної визначеності/невизначеності (рис. 1).

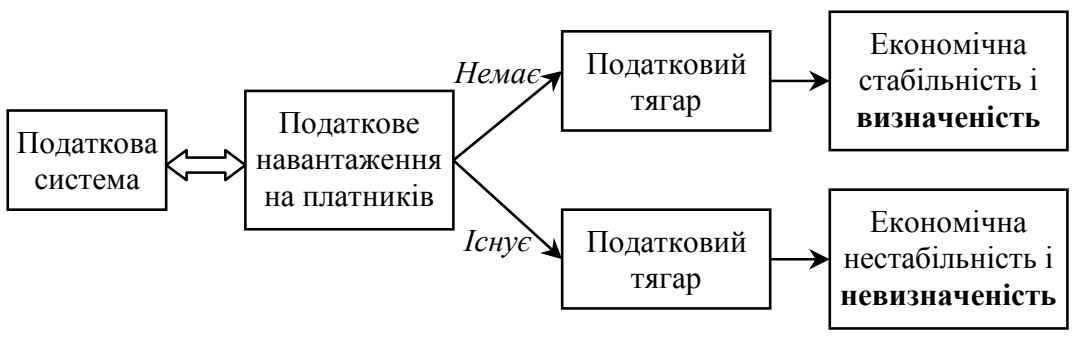

Рис. 1. Алгоритм переходу імпульсу від податкової системи до економічної визначеності/невизначеності

Джерело: розроблено авторами самостійно.

На рисунку ілюстровано ідею формування податковою системою стану економічної визначеності або, навпаки, невизначеності за участі таких передавальних елементів, як податкове навантаження та податковий тягар. За наявності податкового тягаря і за його збільшення створюється економічна невизначеність. Натомість, за відсутності та зменшення податкового тягаря формується економічна визначеність.

У пропонованій теоретичній конструкції (рис. 1) у поняття «податкове навантаження» $\mathrm{i}$ «податковий тягар» вкладається такий зміст.

Податкове навантаження $є$ віддзеркаленням частки сукупних доходів (ВВП), перерозподілених через бюджет у формі податків $(T / Y)$. Оскільки зв'язок між податками та доходами (ВВП) не є лінійним, 
остільки податкові надходження досягають оптимуму лише за певних значень доходів (ВВП).

Податковим тягарем стає надмірне (надлишкове) податкове навантаження. Його (навантаження) надмірність (надлишковість) виявляється принаймні у тому, що після певної межі подальший приріст $(\Delta)$ навантаження може спричиняти такі наслідки:

- гальмувати економічне зростання через втрату підприємницького інтересу до діяльності та через обмеження власного інвестиційного потенціалу підприємств;

- недовіру до влади через порушення принципів соціальної справедливості та несприйняття ії̈ економічних стимулів;

- збільшення необгрунтованих витрат у зв'язку з ускладненням бюрократичних процедур;

- зростання масштабів тіньової економіки через приховування фактичних доходів та ділових операцій.

За пропонованою авторами логікою міркувань, податкове навантаження, яке не містить в собі частини $(\Delta)$ у вигляді податкового тягаря, формує економічну визначеність.

Цінність висновків на підставі порівняння податкових систем двох країн - України та Німеччини - може ставитися під сумнів. Адже країни мають суттєво відмінні економічні потенціали. Це, зокрема, ілюструють дані табл. 1.

За інформацією, поданою у табл. 1, економічний потенціал двох країн суттєво відрізняється за такими параметрами:

- за масштабами створюваного ВВП: у Німеччині ВВП більший у 8,3 разів (у дол. еквіваленті з урахуванням ПКС);

- за загальним рівнем добробуту: ВВП на душу населення в Німеччині перевищує подібний показник в Україні у 4,2 рази;

- за рівнем макроекономічної стабільності: темп інфляції вищий в українській економіці, приблизно, в 4 рази, а рівень безробіття помітно перевищував природний показник та був більшим, ніж у Німеччині, у 2,7 рази;

- за рівнем зовнішньої економічної та фінансової стабільності: в Україні, на відміну від Німеччини, було від'ємне сальдо рахунку поточних операцій, від'ємне сальдо торгового балансу, висока залежність від імпорту енергоносіїв, майже в 10 разів менші обсяги офіційних валютних резервів;

- за рівнем інноваційності економіки: частка інноваційної продукції в експорті України була в 3 рази меншою, ніж у Німеччині [5]. 
Таблиия 1

Показники економічного потенціалу Німеччини та України у 2019 р.

\begin{tabular}{|l|c|c|c|}
\hline \multicolumn{1}{|c|}{ Показник } & $\begin{array}{c}\text { Одиниця } \\
\text { виміру }\end{array}$ & Німеччина & Україна \\
\hline $\begin{array}{l}\text { ВВП за паритетом купівельної } \\
\text { спроможності (ПКС) }\end{array}$ & $\begin{array}{c}\text { млрд міжнар. } \\
\text { дол. }\end{array}$ & 4672,01 & 560,98 \\
\hline ВВП по ПКС на душу населення & міжнар. дол. & 56226 & 13442 \\
\hline Iндекс споживчих цін & $\%$ & $1,3 \%$ & $7,9 \%$ \\
\hline Рівень безробіття & $\%$ & $3,1 \%$ & $8,5 \%$ \\
\hline $\begin{array}{l}\text { Баланс рахунку поточних операцій, } \\
\text { дол. США }\end{array}$ & $\begin{array}{c}\text { млрд дол. } \\
\text { США }\end{array}$ & 273,2 & $-4,2$ \\
\hline $\begin{array}{l}\text { Баланс рахунку поточних операцій, } \\
\text { \% до ВВП }\end{array}$ & \% & 7,1 & $-2,7$ \\
\hline Міжнародні резерви & млрд дол. США & 224 & 25 \\
\hline Експорт товарів & млрд дол. США & 1464 & 46 \\
\hline Експорт послуг & млрд дол. США & 347 & 17 \\
\hline Експорт високотехнологічних товарів & млрд дол. США & 207 & 1 \\
\hline $\begin{array}{l}\text { Експорт високотехнологічних } \\
\text { товарів у \% від експорту товарів }\end{array}$ & \% & 16,4 & 5,4 \\
\hline Імпорт товарів і послуг & млрд дол. США & 1588 & 76 \\
\hline Імпорт товарів & млрд дол. США & 1217 & 60 \\
\hline Імпорт послуг & млрд дол. США & 371 & 16 \\
\hline Імпорт продовольства & \% & 7,8 & 8,6 \\
\hline $\begin{array}{l}\text { Імпорт паливно-енергетичних у \% від } \\
\text { імпорту товарів }\end{array}$ & \% & 8,5 & 23,5 \\
\hline Експорт товарів & млн дол. США & 1489152 & 50066 \\
\hline Імпорт товарів & млн дол. США & 1234454 & 60607 \\
\hline
\end{tabular}

Джерело: розроблено авторами на основі [6; 7].

Визнаючи факт суттєвих відмінностей економічних потенціалів двох країн, однак, не можна ігнорувати таке.

По-перше, є підстави для припущення, що нерелевантність невідповідність об'єктивним потребам економіки та суспільства української податкової системи саме й стає однією з основних причин суттєвих відмінностей потенціалів.

По-друге, в Конституції України зафіксовано вектор руху в бік ЄC - унії, в якій Німеччина посідає провідне місце. Тому економіка та система публічного управління в цій країні об'єктивно мають розглядатися як певний орієнтир для України.

По-третє, Німеччина $є$ важливим торговельним партнером України. До прикладу, за результатами 2019 року Німеччина посіла перше місце серед торговельних партнерів України у Свропі з часткою у 17,31\% від загального товарообігу. Обсяг цього товарообігу становив 9,4 млрд дол. США. Важливо й те, що прирости українського експорту 
до Німеччини в цей рік були більшими, ніж прирости імпорту України 3 Німеччини.

По-четверте, між країнами існує рух інвестицій. Попри те, що інвестиційні потоки не є значними за обсягами, важливими є власне напрямки інвестування. Частка Німеччини в залучених в Україну прямих іноземних інвестиціях у 2019 р. становила 5,16\%. Обсяг інвестицій досягнув 1668,1 млн дол. США. Німеччина посідає четверте місце в переліку іноземних інвесторів України. При цьому левова частка (62\%) німецьких інвестицій спрямовувалася в українську промисловість. Другим, за часткою німецьких інвестицій, був напрямок оптової та роздрібної торгівлі й ремонту автотранспортних засобів (12,5\%), третім - транспорт, складське господарство, поштова та кур'єрська діяльність (8\%). Прямі інвестиції з України до Німеччини у 2019 р. склали 3,42 млн дол. США, причому, 3 них 72,8\% спрямовані у переробну промисловість [8].

Враховуючи зазначені факти економічної взаємодії двох країн, порівняння податкових систем України та Німеччини не позбавлене сенсу та певної наукової цінності.

Власне порівняння української і німецької податкових систем може спиратися на міжнародний рейтинг «Doing Business» від Світового банку. Адже при його створенні беруться до уваги параметри податкових систем країн. Дані для порівняння подано у табл. 2.

Табличя 2

Характеристики податкових систем Німеччини та України у 2020 р., за рейтингом «Doing Business»

\begin{tabular}{|l|c|c|}
\hline \multicolumn{1}{|c|}{ Показник } & Німеччина & Україна \\
\hline Рейтинг оподаткування & 46 & 65 \\
\hline Платежі (кількість у рік) & 9,0 & 5,0 \\
\hline Час (години в рік) & 218 & 328 \\
\hline Загальна ставка податків і зборів (\% від доходів) & 48,8 & 45,2 \\
\hline $\begin{array}{l}\text { Індекс процедур після подачі звітності та сплати } \\
\text { податків (0-100) }\end{array}$ & 97,7 & 86,0 \\
\hline
\end{tabular}

Джерело: розроблено авторами на основі [9].

Інформація, подана у табл. 2, свідчить про таке:

- українська податкова система на 19 позицій рейтингу оцінюється як гірша, ніж німецька;

- податкове навантаження, як \% доходів, сплачених у вигляді податків та зборів у двох країнах, суттєво не відрізняється, і навіть у Німеччині воно є дещо вищим, ніж в Україні $(48,8>45,2)$;

- процедура сплати податків у Німеччині є простішою, оскільки передбачає менші витрати часу на облік та виконання процедур (218 
годин < 328 годин), а загальний індекс процедур у Німеччині є кращим, ніж в Україні.

3 огляду на відмінності у податкових системах країн та на інші відмінності умов підприємницької діяльності, місце України та Німеччини за рейтингом привабливості провадження бізнесу впродовж 2006 2020 рр. було таким (рис. 2).

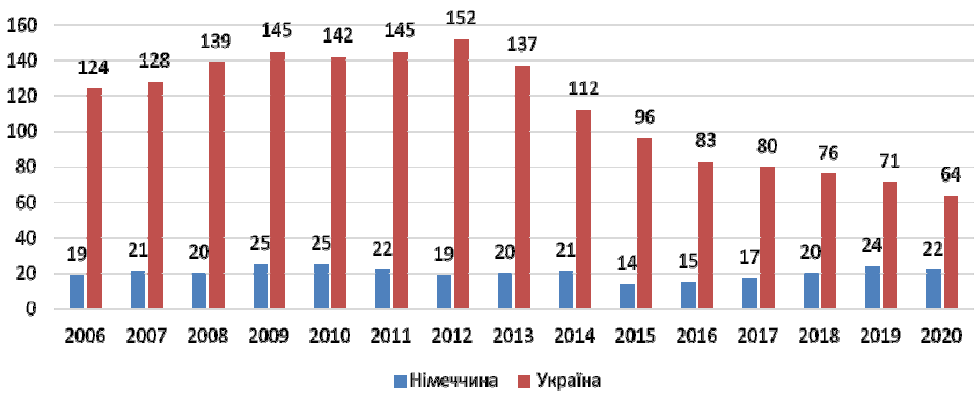

Рис. 2. Рейтинги Німеччини та України, за індексом легкості провадження бізнесу - «Doing Business», y 2006 - 2020 pp. Джерело: розроблено авторами на основі [9].

За інформаціє, поданою у табл. 2 та на рис. 2, Німеччина не $\epsilon$ світовим лідером за якістю податкової системи, перебуваючи у п’ятій десятці країн. Так само країна не є лідером за критерієм легкості ведення бізнесу, часто посідаючи місце лише у третій десятці країн. Але місце Німеччини в рейтингу легкості провадження бізнесу за аналізований період змінювалося несуттєво. Його середнє значення формувалося на рівні 20-ої позиції. Це можна тлумачити як свідчення відносної стабільності та досягнутої економічної визначеності. Натомість, рейтинг України змінювався суттєво, сягнувши найгіршої позиції (152 місце) у 2012 р. і найкращої (64 місце) - у 2020 р. Показовим є стрімке покращання позиції в рейтингу легкості провадження бізнесу після 2013 p.

Принципово важливою при порівнянні податкових систем країн стає ідентифікація основних «бюджетоутворюючих» податків. Інформація про частки податкових надходжень за окремими видами податків у бюджетах двох країн подано на рис. 3 та рис. 4.

Інформація, подана на рис. 3, свідчить про те, що податкова система Німеччини побудована у такий спосіб, що основним «бюджетоутворюючим» податком у ній є податок на доходи громадян $(27,48 \%)$. 


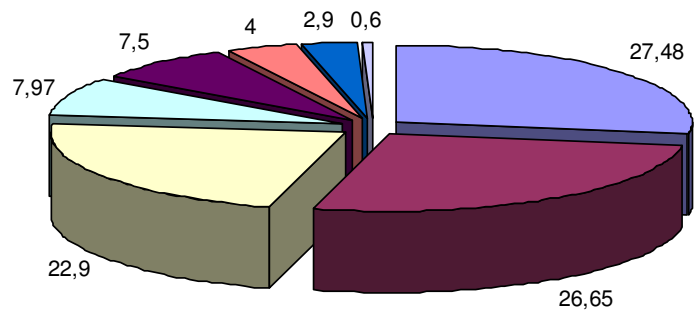

口1. Податок на доходи громадян - $27,48 \%$

口2. Інші (федеральні та окремих земель) податки і збори - 26,65\%

口3. Податок на додану вартість - $22,9 \%$

口4. Податок на прибуток підприємств - 7,97\%

घ. Податок з продажу на імпорт - $7,5 \%$

口6. Корпоративний податок - $4 \%$

口7. Інші податки на доходи - $2,9 \%$

口8. Податки на дивіденди з відсотків на приріст капіталу - 0,6\%

\section{Рис. 3. Структура податкових надходжень до бюджету Німеччини} у 2019 p., \%

Джерело: розроблено авторами на основі [10].

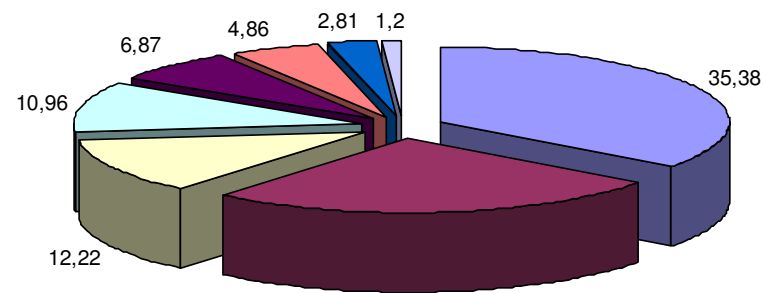

25,7

⒈ Податок на додану вартість - 35,38\%

๑2. Податок на доходи фізичних осіб - $25,7 \%$

口 3. Акцизний податок - $12,22 \%$

$\square$ 4. Податок на прибуток підприємств - 10,96\%

— 5. Місцеві податки та збори, включно з єдиним соціальним податком - 6, 87\%

๑ 6. Рентна плата та плата за використання інших природних ресурсів - 4,86\%

๑ 7. Податки на міжнародну торгівлю та зовнішні операції - $2,81 \%$

๑ 8. Інші податки та збори - 1,2\%

Рис. 4. Структура податкових надходжень до бюджету України y 2019 p., \%

Джерело: розроблено авторами на основі [11].

Інформація 3 рис. 4 дає підстави для висновку, що основним «бюджетоутворюючим» податком, за української податкової системи, 
$\epsilon$ податок на додану вартість (35,38\%). Цей факт лише підтверджує зафіксовану на прикладі багатьох країн закономірність: бюджети у країнах з нижчим рівнем економічного розвитку, здебільшого, формуються за рахунок непрямих податків. До останніх, як відомо, належить i ПДВ. Натомість, у країнах з вищим рівнем розвитку переважаючими у формуванні бюджетів є прямі податки, зокрема податки на доходи фізичних осіб.

Окрім зазначеної відмінності, пов'язаної з різними основними «бюджетоутворюючими» податками, порівняння дає можливість ідентифікувати ще й інші відмінності. Ми акцентуємо увагу лише на тих, які є важливими для розуміння стабілізуючого впливу податків. До таких відмінностей, зокрема, належить і те, що:

- в українській податковій системі не виокремлюється корпоративний податок, що, з огляду на олігархічну модель української економіки та пов'язаність олігархів 3 великими корпораціями (монополіями), є неприродним;

- суттєво різною є частка місцевих податків, відтак, і можливості місцевих бюджетів в Україні є суттєво іншими.

Податкова система Німеччини характеризується стягненням податків на трьох рівнях: загальному (центральному), федеральному та окремих земель. Для усвідомлення іï особливостей і стабілізуючого впливу важливо брати до уваги, як розподілено податки за рівнями (табл. 3).

Таблиця 3

\section{Розподіл податків за рівнями у податковій системі Німеччини}

\begin{tabular}{|c|c|c|}
\hline $\begin{array}{l}\text { Загальні податки - } \\
\text { Gemeinschaftsteuern }\end{array}$ & $\begin{array}{c}\text { Федеральні податки - } \\
\text { Bundessteuern }\end{array}$ & $\begin{array}{c}\text { Податки окремих } \\
\text { земель - Landessteuern }\end{array}$ \\
\hline $\begin{array}{l}\text { - податок на доходи; } \\
\text { - податок на прибуток } \\
\text { підприємств; } \\
\text { - корпоративний } \\
\text { податок; } \\
\text { - податки з продажів, } \\
\text { включно з податком на } \\
\text { додану вартість (ПДВ); } \\
\text { - податки на торгівлю }\end{array}$ & $\begin{array}{l}\text { - податок на енергію; } \\
\text { - податок на тютюн; } \\
\text { - податки на алкоголь, } \\
\text { бренді, вина; } \\
\text { - податок на каву; } \\
\text { - проміжний податок на } \\
\text { товар; } \\
\text { - страховий податок; } \\
\text { - податок на автотранспортні } \\
\text { засоби; } \\
\text { - авіаційний податок }\end{array}$ & $\begin{array}{l}\text { - податок на багатство; } \\
\text { - податок на землю; } \\
\text { - податок на спадок; } \\
\text { - податок на купівлю } \\
\text { землі; } \\
\text { - податок на пиво; } \\
\text { - податок на азартні ігри }\end{array}$ \\
\hline
\end{tabular}

Джерело: розроблено авторами на основі [10].

На основі інформації, поданої в табл. 3, можна робити висновок принаймні про більш різноманітний перелік податків, що збираються на рівні федеральних утворень та окремих земель у Німеччині.

Стрижень стабілізуючого впливу податкової системи пов'язаний 3 формуванням податкових ставок за окремими податками і з податковими пільгами. Їх дослідження дає підстави для висновків про спрямованість 
та пріоритети і податкової системи, і всієї публічної влади. Тому ми розглядаємо ставки та пільги саме під кутом зору тих пріоритетів, на досягнення яких вони можуть бути спрямовані [12-15].

Пріоритет соиіальної стабільності й обмеження нерівності розподілу багатства виявляється у таких особливостях податкової системи Німеччини:

- прогресивному оподаткуванні доходів громадян 3 диференціацією ставок від $14 \%$ до $45 \%$, при неоподаткованому річному мінімумі доходів у 8,82 тис. євро та найбільшій податковій ставці у 42\%, що застосовується до доходів, які перевищують річний обсяг у 53,6 тис. євро;

- неоподаткованій щомісячній зарплаті малозабезпечених родин у вигляді: зменшення бази оподаткування для неповних родини з дітьми (на 1077 С), а також для родин, де один з ії членів втратив роботу (на 945 євро) тощо;

- застосуванні зменшеної - на рівні 7\% - ставки податку на додану вартість (ПДВ) для продуктів харчування (овочів, фруктів, молочних виробів, борошна та круп), а також для книжок і газет, на противагу загальній податковій ставці у 19\% для всіх інших товарів;

- виокремленні двох груп платників податку на доходи фізичних осіб: 1) осіб самостійного працевлаштування, що створюють робочі місця - індивідуальних підприємців, фрілансерів, адвокатів, податкових консультантів, лікарів, якщо у них є власна практика (Einkommensteuer), 2) найманих працівників та чиновників (Lohnsteuer);

- зменшенні бази оподаткування на величину, так званих «витрат, пов'язаних з отриманням доходу» (Werbungskosten), до яких належать витрати на переїзди до місця роботи, а також ті, що пов'язані зі зміною місця роботи при їі втраті;

- прогресивному податку на дарування та успадкування 3 диференціацією ставок від 7\% до 50\% й у встановленні межі у 75 тис. євро для застосування мінімальної ставки;

- вищому, ніж при сплаті податку на прибуток, рівні податку на дивіденди (ставка 25\%) та вищому рівні податку на приріст доходів і капіталу, отриманих при продажах цінних паперів (ставка 26,375\%);

- фактичній сплаті податку на багатство при придбанні будьякої нерухомості на території країни з диференційованою ставкою від $3,5 \%$ до $5 \%$.

Пріоритет підтримки невеликих підпиємств, що має такі прояви:

- стандартна ставка корпоративного податку на прибуток становить $15 \%$ та збільшується для корпорацій на 5,5\%, так званого податку «на солідарність» для підтримки приєднаних (Східних німецьких) земель;

- базовою для некорпоративних підприємств є ставка 3,5\%, яка коригується на коєфіцієнт, встановлений окремо для кожного муніципалітету; 
- за податковими ставками, що коливаються в межах від 14 до $17,15 \%$, сплачуються податки підприємствами, прибуток яких перевищує 24,5 тис. євро;

- ставка податку на прибуток може встановлюватися індивідуально місцевими податковими органами.

Пріоритет стимулювання експортної діяльності, передусім за межами $\mathrm{CC}$, реалізується у такий спосіб:

- не оподатковується податком на продаж операції з постачання товарів та послуг за межі СС, а також авіаційні та морські перевезення.

Пріоритет реагування на актуальні загрози для економіки та суспільства забезпечується, зокрема, так:

- для подолання економічних наслідків Covid-19 уряд Німеччини знизив загальну ставку ПДВ з 19\% до 16\%, а пільгову ставку на продукти харчування - 3 7\% до 5\%.

Пріоритет підтримки фермерства та екологічного виробництва у вигляді «антиподатків» - субсидій та субвенцій - втілюється у таких діях:

- використанні урядом Німеччини коштів зі спільних фондів СС (до прикладу, 58 млрд євро у 2017 р.) на спеціальну підтримку виробників сільськогосподарської продукції. Зокрема, такими фондами є Свропейський сільськогосподарський гарантійний фонд (EAGF) та Свропейський сільськогосподарський фонд розвитку сільських районів (EAFRD). Частка Німеччини в обсязі 6,5 млрд євро становить 11,2\% від обсягу фондів ЄC [16]. Вона розподіляється урядом Німеччини між фермерами 3 урахуванням таких обставин: 1) масштаб підприємства (кількість га землі на господарство), 2) рівня розвитку регіону, в якому працює господарство, 3) природно-кліматичних та екологічних умов господарювання;

- додатковій підтримці фермерським господарствам на структурну перебудову, екологічні технології тощо від федерального уряду Німеччини, зокрема, через фонди ELER-Topf, ELER-Hilfen, ELER-Förderung.

Важливо те, що надання пільг виробникам сільськогосподарської продукції є повністю прозорим процесом. Адже існує відкрита база даних, з якої можна дізнатися, які підприємства Німеччини, коли та в якому обсязі мали підтримку. До прикладу, відомо, що кількість таких отримувачів уже сягнула більше 310 тисяч підприємств.

Важливим моментом порівняння податкових систем країн $є$ дослідження того, який дохід (зарплата) залишається у платника після оподаткування. Цифрова ілюстрація відповіді на це питання 3 використанням реальних ставок сплачуваних податків та співставних баз оподаткування подано у табл. 4 та табл. 5 .

Як свідчить інформація, подана в табл. 4, податкове навантаження на зарплату в Німеччині суттєво (на 8,76 в. п.) відрізняється в бік послаблення для родин 3 дітьми. Воно формується у процесі сплати шістьох податків: податку на дохід, внеску солідарності з приєднаними федеральними землями, відрахувань у пенсійний фонд, відрахувань на 
медичне страхування, відрахувань на страхування на випадок необхідності догляду, відрахувань на страхування на випадок безробіття. Перелік відрахувань засвідчує всебічну й деталізовану за напрямками соціальну захищеність працюючого платника.

Формування зарплати після сплати податків у Німеччині

Таблиия 4

\begin{tabular}{|c|c|c|c|c|c|}
\hline \multirow[t]{2}{*}{ № } & \multirow[t]{2}{*}{ Зарплата та сплачувані податки } & \multicolumn{2}{|c|}{$\begin{array}{c}\text { Особа, що } \\
\text { перебуває у шлюбі }\end{array}$} & \multicolumn{2}{|c|}{$\begin{array}{c}\text { Особа у шлюбі } \\
\text { та } 3 \text { дітьми }\end{array}$} \\
\hline & & євро & $\%$ & євро & $\%$ \\
\hline 1. & $\begin{array}{l}\text { Щомісячна зарплата (брутто) на рівні } \\
\text { середньої й, приблизно, тотожної } \\
\text { доходу програміста-нерезидента } \\
\text { країни, за «блакитною картою» }\end{array}$ & 5000 & 100 & 5000 & 100 \\
\hline 2. & Податок на дохід & 1023,50 & 20,47 & 636,16 & 12,72 \\
\hline 3. & $\begin{array}{l}\text { Внесок солід } \\
\text { федеральним }\end{array}$ & 56,29 & 1,12 & 16,51 & 0,33 \\
\hline 4 & ний фонд & 465,00 & 9,30 & 465 & 9,30 \\
\hline 5. & $\begin{array}{l}\text { Відрахування на медичне } \\
\text { страхування }\end{array}$ & 389,41 & 7,79 & 389,41 & 7,79 \\
\hline & $\begin{array}{l}\text { Відрахування на страхування на } \\
\text { випадок необхідності догляду }\end{array}$ & 67,48 & 1,35 & 56,42 & 1,13 \\
\hline 7. & $\begin{array}{l}\text { Відрахування на страхування на } \\
\text { випадок безробіття }\end{array}$ & 75,00 & 1,50 & 75,00 & 1,50 \\
\hline 8. & $\begin{array}{l}\text { Загальна сума сплачених податків } \\
\text { та відрахувань }\end{array}$ & 2076,68 & 41,53 & 1638,50 & 32,77 \\
\hline & $\begin{array}{l}\text { Щомісячна зарплата (нетто) після } \\
\text { оподаткування }\end{array}$ & 2923,32 & 58,47 & 3361,50 & 67,23 \\
\hline
\end{tabular}

Джерело: розроблено авторами на основі [17].

Таблиия 5

Формування зарплати після сплати податків в Україні у 2020 р.

\begin{tabular}{|c|l|c|c|}
\hline № & \multicolumn{1}{|c|}{ Податок } & грн & $\mathbf{1}$ \\
\hline 1. & $\begin{array}{l}\text { Щомісячна зарплата (брутто), що відповідає середньому } \\
\text { рівню зарплат у великих містах країни у 2020 р. }\end{array}$ & 12000 & 100 \\
\hline 2. & Військовий збір & 180 & 1,5 \\
\hline 3. & Податок з доходів фізичних осіб & 2160 & 18 \\
\hline 4. & $\begin{array}{l}\text { Єдиний соціальний внесок (нараховує і сплачує } \\
\text { роботодавець) }\end{array}$ & 2640 & 22 \\
\hline 5. & Загальна сума сплачених податків та відрахувань & 4980 & 41,5 \\
\hline 6. & Щомісячна зарплата (нетто) після оподаткування & 9660 & $\mathbf{5 8 , 5}$ \\
\hline
\end{tabular}

Джерело: розроблено авторами з використанням офіційних джерел на основі [18; 19].

Інформація, подана у табл. 5, свідчить про податкове навантаження на зарплату українців на рівні пільгового навантаження німецьких родин 3 дітьми. 3 огляду на існування й непільгового оподаткування зарплат, податкове навантаження в Німеччині є дещо вищим, ніж в Україні. 
Українське податкове навантаження на заробітну плату формується 3 використанням трьох податків: військового збору, податку з доходів фізичних осіб, єдиного соціального внеску. Об'єднання платежів із соціального страхування в єдиний податок позбавляє їх (платежі) конкретності й, імовірно, позитивного стимулюючого впливу.

\section{Висновки:}

За результатами порівняння податкових системи України та Німеччини, ми робимо такі висновки:

- українська система оподаткування характеризується існуванням значного податкового тягаря, тому її стабілізуючий потенціал, наразі, не реалізується. Основним підтвердженням цього $€$ те, що при приблизно однаковому податковому навантаженні на доходи та на заробітну плату українська економіка має на порядок гірші показники добробуту, зайнятості, рівня цін, фінансових та зовнішньоекономічних балансів, офіційних валютних резервів тощо. Негативний внесок податкової системи - того, як (у який спосіб) сплачуються податки в Україні - в цьому відставанні за основними економічними та соціальними показниками $\epsilon$ незаперечним;

- 3 огляду на досвід Німеччини, податкова система, яка здатна формувати стабільність та економічну визначеність, повинна мати такі пріоритети:

- формування, 3 використанням податків, стану соціальної справедливості та запобігання необгрунтованій нерівності розподілу доходів і багатства,

- підтримку через податкові ставки та податкові пільги крихкого невеликого бізнесу й фермерських господарств, експортерів вітчизняної продукції,

- швидке реагування на виклики та загрози економіці й суспільству шляхом застосування доцільних механізмів послаблення податкового навантаження у кризових ситуаціях.

\section{Лimepamypa:}

1. Qingwang Guo, Bingyang Lv, Ximing Yue. Regulating Effect of Tax on Chinese National Income Distribution. 1st Edition. 30 September 2020. 274 p.

2. Bing Xu \& Lili Li \& Yan Liang \& Mohib Ur Rahman, Measuring Risk Allocation of Tax Burden for Small and Micro Enterprises. Sustainability, MDPI. 2019. Vol. 11(3). P. 1-20.

3. Alyeksyeyev I., Paranchuk S., Chervinska O. Controlling the tax burden of the enterprise in the reality of ukrainian legislation. Financial sciences nauki o finansach. 2018. Vol. 23. №1. P. 22-32.

4. Radionova I., Boger O. Tax burden and innovation activities: The interrelation problem. Economic Annals-XXI. 2014. №1-2(1). P. 65-69. 
5. Торговельно-економічне співробітництво. Матеріали сайту Посольства України у Федеративній Республіці Німеччина. 22.11.2019. URL : https://germany.mfa.gov.ua/spivrobitnictvo/torgovelno-ekonomichnespivrobitnictvo\#: :text=У\%202019\%20році\%20обсяг\%20торгівлі,склав\% 20близько $\% 209 \% 2 \mathrm{C} 4 \%$.

6. Мировой атлас данных. Германия. Материалы сайта knoema. URL : https://knoema.ru/atlas/Германия.

7. Мировой атлас данных. Украина. Материалы сайта knoema. URL : https://knoema.ru/atlas/Украина.

8. Торговельно-економічне співробітництво між Україною та Німеччиною. Матеріали сайту Посольство України у Федеративній Республіці Німеччина. URL : http://germany.old.mfa.gov.ua/ua/ukrainede/trade.

9. Doing Business. Оценка бизнес регулирования. Материалы Всемирного банка. URL : https://www.doingbusiness.org.

10. Kassenmäßige Steuereinnahmen des Bundes, der Länder und der Gemeinden nach Steuerarten vor der Steuerverteilung in Millionen Euro. Destatis. Statistisches Bundesamt. URL : https://www.destatis.de/DE/Themen/ Staat/Steuern/Steuereinnahmen/Tabellen/steuerhaushalt-kassenmaessigesteuereinnahmen-vor-steuerverteilung.html.

11. Доходи зведеного бюджету України. Матеріали сайту Міністерства фінансів України. URL : https://index.minfin.com.ua/ua/ finance/budget/cons/income/2019/.

12. Reduktion der Mehrwertsteuer in Deutschland. URL : https://ventopay.com/news/reduktion-der-mehrwertsteuer-von-19-auf-7/.

13. Höchststeuersatz der Einkommensteuer in Deutschland bis 2020. Statista. URL : https://de.statista.com/statistik/daten/studie/38327/umfrage/ entwicklung-des-hoechststeuersatzes-in-deutschland/.

14. Офіційний сайт Finance Business Service. Оподаткування в Німеччині. URL : https://fbs-tax.com/uk/tax-planning/germany/taxation-germany.

15. Борисова М. Податки в Німеччині: багаті й бездітні платять більше. 30.06.2020. URL : https://p.dw.com/p/3eOen.

16. Von Nicolai Kwasniewski, Maria Marquart, Marcel Pauly und Patrick Stotz. Wohin die Agrarsubventionen fließen. 29 May2018. URL : https://www.spiegel.de/wirtschaft/soziales/eu-subventionen-landwirtschafterklaerung-in-karten-a-1210055.html.

17. Buro Reinhardt \& Weckbecker Steuerbereatungsgesellschaft $\mathrm{mbH}$. URL : https://web2.cylex.de/firma-home/reinhardt-_-weckbeckersteuerberatungsgesellschaft-mbh-8106014.html

18. Податковий кодекс України : Закон України. Редакція від 23.12.2020. URL : https://zakon.rada.gov.ua/go/2755-17.

19. Офіційний сайт Міністерства фінансів України. Середня місячна зарплата по регіонах України в 2020 p. URL : https://index. minfin.com.ua/ua/labour/salary/average/. 


\title{
ІННОВАЦЙНЕ ПІДПРИЕМНИЦТВО ТА СТАРТАПИ ДЛЯ СТАБІЛІЗАЦІЇ ЕКОНОМІКИ: СВІТОВИЙ ДОСВІД ТА ЗАСТОСУВАННЯ В УКРАЇНІ
}

\author{
Троц Ірина Вікторівна, \\ кандидат економічних наук, \\ дочент кафедри теоретичної та прикладної економіки, \\ ВНЗ «Університет економіки та права «КРОК», \\ ORCID: https://orcid.org/0000-0001-9608-0591,
}

\begin{abstract}
Дзюбко Віктор Васильович старший викладач кафедри теоретичної та прикладної економіки, ВНЗ «Університет економіки та права «КРОК» ORCID: https://orcid.org/0000-0003-0759-457X
\end{abstract}

\begin{abstract}
Анотація. У розділі досліджується зв'язок між розвитком інноваційного підприємництва, з одного боку, та стабілізацією в умовах економічної невизначеності - 3 іншого. Розглянуто успішні форми інноваційного підприємництва - стартапів у інших країнах та в Україні. Зроблено узагальнення стосовно факторів сприяння та обмеження інноваційного підприємництва. Досліджено національні моделі інноваційного розвитку й інструменти сприяння інноваційному підприємництву у формі стартапів. Визначено особливості інноваційної діяльності в Україні та окреслено умови та можливі перспективи іiі подальшого розвитку, 3 огляду на високий рівень економічної невизначеності.
\end{abstract}

Ключові слова: інноваційна діяльність, стартап, інноваційне підприємництво, національна інноваційна модель розвитку, рейтинги стартапів, фонд розвитку стартапів.

Дослідження інноваційного підприємництва $є$ актуальним для української економіки та суспільства, які потерпають від недовикористання інтелектуального та природного потенціалу країни. Ми припускаємо, що традиційні форми організації підприємницької діяльності, здебільшого, вичерпали свої можливості. Тому перспективними, з огляду на необхідність стабілізації національної економіки, стають принципово нові, креативні форми провадження підприємництва. Саме таку новизну форми та змісту демонструють стартапи. Попри існування сотень досліджень, здійснених фахівцями різних країн у царині інноваційної діяльності й стартапів, існують лакуни в аналізі можливостей і обмежень такої діяльності саме в Україні. Потребує відповіді питання про потенціал інноваційного підприємництва для стабілізації та досягнення вищого рівня визначеності української економіки. 
Метою цього дослідження є актуалізація проблеми українського інноваційного підприємництва та його організаційної форми - стартапів підприємств, які започатковують принципово нове виробництво. Ідеться, зокрема, про ідентифікацію й оцінювання можливостей та перешкод на шляху реалізації такої діяльності в Україні. Ідентифікація й оцінювання здійснюються 3 метою з'ясування впливу інноваційної сфери на стабілізацію підприємництва та визначеність економіки.

Ми спиратимемося на низку ключових понять, без чіткого окреслення змісту яких не може бути досягнута мета дослідження. Це такі поняття, як інноваційна діяльність, інноваційне підприємництво, моделі інноваційного розвитку країни, стартапи. Не акцентуючи увагу на деталях, визначатимемо основне у змісті згаданих понять.

Інноваційна - це діяльність, що має такі визначальні ознаки:

- спрямована на створення нового або суттєво вдосконаленого продукту, технологічного процесу, способу надання послуг;

- безпосередньо пов'язана з удосконаленням знань, з науковими дослідженнями та розробками інноваційних ідей, що втілюються у принципово нові товари, послуги, технології, які користуються попитом споживачів.

Інноваційне підприємництво - особливий вид економічної діяльності, орієнтований на інновації, що має такі ознаки:

- передбачає перманентний пошук нових можливостей та орієнтоване на здійснення нових проєктів;

- стикається на початкових етапах реалізації з відносно більшими ризиками, тому передбачає організаційні та економічні запобіжники й вищу відповідальність ініціаторів;

- вмотивоване перспективою отримання інноваційних (суттєво вищих від середніх) прибутків або інших вигод;

- формує значні конкурентні переваги на ринку.

Успіх інноваційної діяльності визначається економічною політикою урядів країн, станом національних ринків та рівнем макроекономічної стабільності. 3 огляду на це, є підстави для виокремлення поняття (й відповідного явища) «національні моделі інноваційного розвитку». Інформація про найбільш відомі та такі, що мають чіткі ознаки, моделі ілюстровано на рис. 1 .

На рис. 1 ілюстровано три моделі інноваційного розвитку, адаптовані до конкретних умов окремих країн.

Вагомою перевагою стрімкого розвитку інноваційної діяльності у розвинених країнах $є$ багатоканальність та варіативність джерел фінансування й стимулювання. Зокрема, фінансування науково-дослідних і дослідно-конструкторських робіт (НДДКР) та інноваційної діяльності у США, Японії, країнах Західної Свропи характеризується поєднанням різних джерел. $€$ підстави для виокремлення таких каналів фінансування інноваційної діяльності з відповідними джерелами (рис. 2). 


\begin{tabular}{|c|c|}
\hline $\begin{array}{c}\text { Орієнтовані на лідерство } \\
\text { в науці й інноваційному } \\
\text { розвитку }\end{array}$ & $\begin{array}{l}\text { - спрямовуються значні (у \% до ВВП) фінансові } \\
\text { ресурси на фундаментальні та прикладні } \\
\text { дослідження, реалізуються цільові й комплексні } \\
\text { форсайт-проєкти з моделювання майбутнього; } \\
\text { - } \boldsymbol{C} \boldsymbol{\boldsymbol { H }} \text {, Велика Британія, Франція }\end{array}$ \\
\hline
\end{tabular}

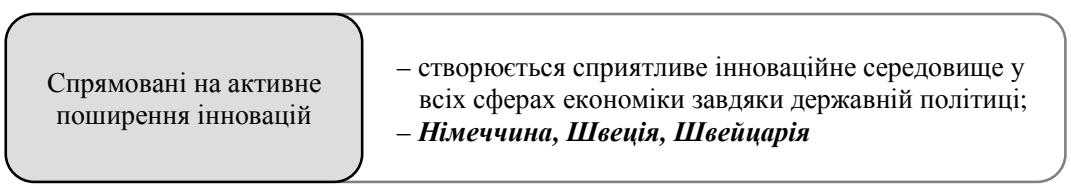

Сприятливі щодо реалізації досягнень світового науковотехнічного прогресу
- активно координуються дії влади та бізнесу в напрямку реалізації всіх можливих видів інновацій;

- КНР, Японія, Південна Корея

Рис. 1. Моделі інноваційного розвитку економічно розвинених країн

Джерело: сформовано авторами на основі [1].

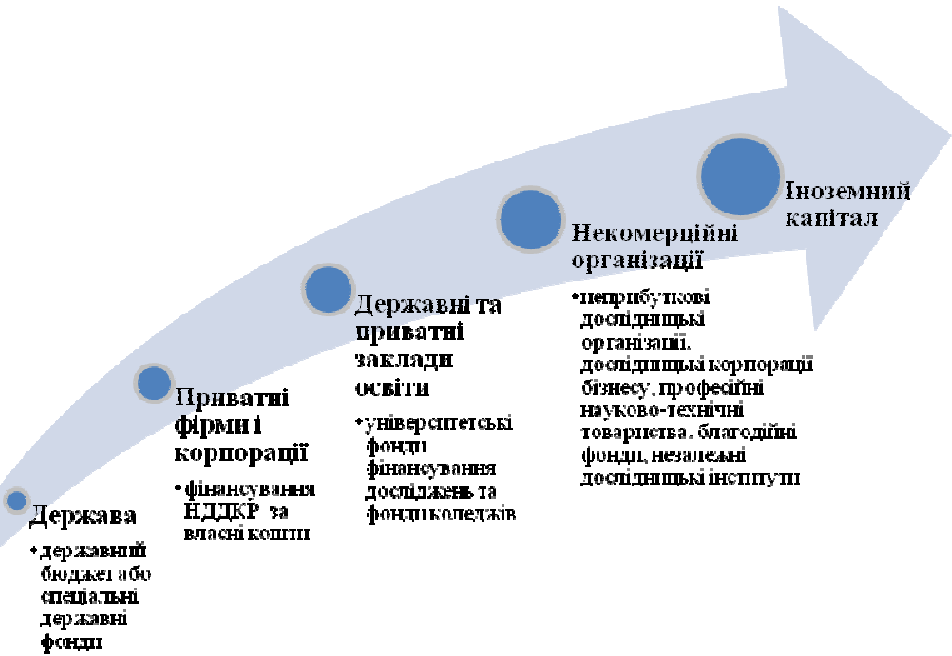

Рис. 2. Основні джерела фінансування інноваційної діяльності у розвинених країнах

Джерело: сформовано авторами самостійно.

На рис. 2 ілюстровано п'ять каналів фінансування науково-дослідної діяльності, які охоплюють внутрішні державні, створені колективно та приватно, а також зовнішні джерела.

3 досвіду США, Японії, Німеччини, Великої Британії, Франції та Канади випливає необхідність і доцільність стимулювання інноваційного 
підприємництва за рахунок бюджетних коштів. Вирішальним інструментом такого фінансування стає інноваційна політика держави. У країнах 3 розвиненою ринковою економікою уряди фінансують від 20 до 50\% національних наукових інноваційних витрат. Частка витрат на дослідницькі роботи та інноваційні розробки в загальній сумі державних витрат $\epsilon$ невеликою. Але впродовж 20 років вона залишається стабільною і становить у США 6-7\%, у Німеччині, Франції, Великий Британії та Італії - 4-5\%, в Японії - 3-5\% [1].

Важливим джерелом фінансування ризикового інноваційного капіталу в економічно розвинених країнах можуть ставати банки, пенсійні фонди, страхові компанії. Але в різних країнах частки та впливовість згаданих джерел є різною.

Світовий досвід свідчить про ефективність венчурного фінансування, яке передбачає прямі інвестиції на ранній стадії реалізації проєктів у високотехнологічних сферах. Як відомо, таке фінансування стає рятівним для підприємств з обмеженим доступом до банківських кредитів. Венчурне фінансування малих і середніх підприємств сприяло технологічному розвитку в сферах біотехнології, інформаційних технологій, напівпровідникової електроніки, обчислювальної техніки. Найбільшого поширення венчурне фінансування досягло в США, Німеччині, Великій Британії, Японії, Нідерландах. Якщо у США левова частка венчурного фінансування припадає на IT-підприємства, то в Західній Європі венчурні інвестиції досить рівномірно розподіляються між різними галузями та сферами. Аналіз міжнародного досвіду формування інноваційних економік і організації інноваційного підприємництва дає підстави для виокремлення таких важливих моментів інноваційної діяльності, як: фактори сприяння інноваційній діяльності (фактори стимулюючого впливу); фактори, що уповільнювали інноваційну діяльність (фактори стримуючого впливу); організаційні форми (інститути підтримки) інноваційної діяльності. Виокремлені моменти інноваційної діяльності подано в аналітичній табл. 1.

В аналітичній табл. 1 подано інформацію про сприятливі та несприятливі для інноваційної діяльності фактори впливу. Вони виявилися в діяльності не лише інноваційних лідерів світу, а й країн швидкого просування в інноваційній сфері. Й тих, й інших можна ідентифікувати як інноваційних інсайдерів. Для країн інноваційних аутсайдерів особливо корисним є досвід створення організаційних структур (інститутів стимулювання) інновацій. Адже саме інститути забезпечують дію факторів стимулювання.

Апробованою та результативною в багатьох країнах формою інноваційних підприємств $є$ «стартапи». Існують різні тлумачення змісту цього поняття. Для науковців та практиків країн, які запозичують досвід стартапів, важливо враховувати різні аспекти цього змісту. Тому ми акцентуємо увагу саме на особливостях тлумачення змісту. 


\section{Фактори та інститути інноваційної діяльності}

\begin{tabular}{|c|c|c|}
\hline $\begin{array}{c}\text { Фактори } \\
\text { стимулюючого впливу }\end{array}$ & $\begin{array}{c}\text { Фактори } \\
\text { дестимулюючого впливу }\end{array}$ & $\begin{array}{c}\text { Організаційні форми } \\
\text { (інститути) підтримки } \\
\text { інноваційної діяльності }\end{array}$ \\
\hline $\begin{array}{l}\text { - послідовна і довгострокова } \\
\text { інноваційна політика } \\
\text { держави з чітко } \\
\text { сформульованими цілями та } \\
\text { інструментами; } \\
\text { - раціональне використання } \\
\text { інноваційного потенціалу } \\
\text { для формування нового типу } \\
\text { економіки - інноваційної; } \\
\text { - системна взаємодія } \\
\text { приватного, науково- } \\
\text { дослідного та освітнього } \\
\text { секторів; } \\
\text { - цільова підтримка важливих } \\
\text { для формування } \\
\text { інноваційного потенціалу } \\
\text { напрямків діяльності, які не } \\
\text { можуть розвиватися на } \\
\text { основі власних ресурсів; } \\
\text { - реалізація програм } \\
\text { комерціалізації інновацій; } \\
\text { - доцільне з огляду } \\
\text { національних інтересів } \\
\text { залучення іноземних } \\
\text { інвестицій транснаціональних } \\
\text { корпорацій; } \\
\text { - законодавство з захисту прав } \\
\text { інтелектуальної власності та } \\
\text { його послідовна реалізація; } \\
\text { - систематичне вивчення та } \\
\text { адаптація кращого } \\
\text { міжнародного досвіду. }\end{array}$ & $\begin{array}{l}\text { - відносно низька частка } \\
\text { приватного бізнесу у } \\
\text { фінансуванні НДДКР } \\
\text { (Франція, Швеція, } \\
\text { Нідерланди, Індія); } \\
\text { - відстороненість малого } \\
\text { бізнесу від інноваційної } \\
\text { діяльності (Франція, } \\
\text { Швеція, Нідерланди, } \\
\text { Японія); } \\
\text { - «витік мізків» - міграція } \\
\text { кваліфікованих } \\
\text { працівників (Франція, } \\
\text { Німеччина); } \\
\text { - територіальні диспропорції } \\
\text { в інноваційному розвитку } \\
\text { (Німеччина, Індія, Китай, } \\
\text { Франція, Норвегія); } \\
\text { - швидке старіння населення } \\
\text { (країни Європейського } \\
\text { Союзу); } \\
\text { - нерозвинені ринки } \\
\text { венчурного капіталу } \\
\text { (Данія, Німеччина); } \\
\text { - організаційно-правові } \\
\text { перепони на шляху } \\
\text { комерціалізації інновацій } \\
\text { (Індія, Німеччина, Бразилія); } \\
\text { - «забюрократизованість» } \\
\text { процедур, пов’язаних з } \\
\text { підприємницькою } \\
\text { діяльністю (Індія, } \\
\text { Бразилія, країни Азії). }\end{array}$ & $\begin{array}{l}\text { - спеціальні організації } \\
\text { та органи, відповідальні } \\
\text { за визначення і } \\
\text { реалізацію інноваційної } \\
\text { політики (майже всі } \\
\text { країни); } \\
\text { - активна взаємодія з } \\
\text { іншими країнами в } \\
\text { обміні технологіями } \\
\text { (майже всі країни); } \\
\text { - створення інноваційних } \\
\text { кластерів (Франція, } \\
\text { Німеччина); } \\
\text { - здійснення основних } \\
\text { інновацій у співпраці з } \\
\text { транснаціональними } \\
\text { корпораціями (Швеція, } \\
\text { Франція, Нідерланди, } \\
\text { Індія, Японія); } \\
\text { - організаційне } \\
\text { забезпечення } \\
\text { безкоштовної освіти, } \\
\text { орієнтованої на } \\
\text { виявлення та просування } \\
\text { талановитої молоді } \\
\text { (Німеччина, Норвегія); } \\
\text { - використання } \\
\text { «інноваційних } \\
\text { ваучерів» (Нідерланди, } \\
\text { Велика Британія, } \\
\text { Німеччина). }\end{array}$ \\
\hline
\end{tabular}

Джерело: складено авторами на основі [1].

Як відомо, термін «стартап» пов'язаний 3 назвою малого підприємства «Start Up», заснованого у США двома студентами Стенфордського університету. Йдеться про У. Хьюлетта та Д. Паккарда, які пізніше стали творцями всесвітньо відомої компанії у сфері інформаційних технологій - Hewlett-Packard. Відтак, при вживанні поняття «стартап» виникає асоціація з підприємством, що забезпечує прорив у певній сфері, реалізує принципово нову ідею та швидко зростає.

Відомий американський підприємець Стів Бланк, який створив вісім успішних стартапів, визначав стартап як організацію, що «сформована 
для пошуку повторюваної і масштабованої бізнес-моделі» [2]. У цьому визначенні акцентовано увагу на започаткуванні того, що повторюється іншими та набуває поширення.

Визнаний фахівець у сфері венчурного капіталу Пол Грем, який став засновником Y Combinator та Yahoo! Store i написав книгу «Хакери та Художники», зазначав таке: це «компанія, спроєктована з метою швидкого зростання» [3]. У цьому визначенні акцентована обставина динамічності розвитку бізнесу.

Американський ініціатор руху «Ощадливий стартап», спеціаліст у сфері управління бізнесом високих технологій Ерік Ріс зазначає, що «стартап - це людський інститут, спроектований для створення нового продукту або сервісу в умовах критичної невизначеності» [4]. Наведене визначення цікаве тим, що в ньому акцентовано увагу на новизні створюваного продукту та на необхідності діяти за умов невизначеності.

У роботі «Священна книга стартапера. Як збудувати успішну компанію» Стіва Бланка та Боба Дорфі [5] подано декілька визначень стартапів:

- стартап - це процес виходу на ринок новоствореної компанії за короткі терміни і, як правило, при мінімальних вкладеннях;

- стартап - це не зменшена версія великої компанії, а організація, що займається пошуком прибуткової бізнес-моделі, яку можна масштабувати;

- стартап - це форма бізнесу, яка передбачає випробування не тільки фінансових можливостей іiі ініціаторів, а й їхньої витримки, спритності та сміливості;

- стартап - це проєкт реалізації набору неперевірених гіпотез 3 надзвичайно високими ризиками.

Найбільш доречним нам видається визначення, за яким стартап - це нещодавно створена компанія, яка формує свій бізнес на основі інновацій (інноваційних технологій), має у розпорядженні обмежені ресурси та орієнтована на швидкий розвиток та завоювання нового сегменту ринку.

На перший погляд, кожна новостворена компанія може називатися стартапом. Але таке тлумачення є хибним. Те, що принципово відрізняє стартап від звичайного новоствореного підприємства, віддзеркалено на рис. 3.

Суть поданої на рис. 3 ідеї у тому, що стартап відрізнається від звичайного новоствореного підприємства принаймні за чотирма ознаками, а саме: за інноваційністю проєкту, за браком інвестицій через високу ризиковість проєкту, за орієнтованістю на швидке зростання та за низькою ймовірністю успішності. 


\section{Інноваційність ідеї проєкту}

- зазвичай стартапи пов'язані з новими продуктами та послугами, що створюють новий сегмент ринку

Обмеженість початкових інвестицій, насамперед через невизначеність результатів та високі ризики інвестування

- здебільшого, початкові інвестиції стартапів - це власні кошти засновників проєкту та їх оточення, що формують так званий стартовий капітал

Орієнтованість на швидкий розвиток та швидке отримання переваг

- стартапи створюються, в середньому, впродовж 3-4 місяців, винятком можуть стати лише високотехнологічні стартапи, на «запуск» яких може знадобитися до року

Низька ймовірність на успіх проєктів

- за статистикою, 70\% стартапів зникають у перший рік, а з тих, що продовжують існувати, ще $40 \%$ не досягає дворічного терміну

\section{Рис. 3. Ключові відмінності стартапів від звичайних компаній} Джерело: створено авторами самостійно.

Окрім чотирьох зазначених особливостей змісту, стартап, як форма бізнесу, має певні особливості так званого «життєвого циклу». Повний «життєвий цикл стартапу», на наш погляд, охоплює такі 5 етапів (рис. 4). Переважна більшість стартапів припиняє існування на перших трьох етапах.

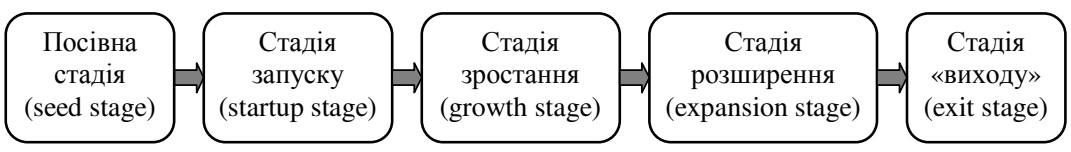

\section{Рис. 4. «Життєвий цикл» стартапів}

Джерело: розроблено авторами на основі [6].

Ілюстровані на рис. 4 етапи «життєвого циклу» стартапів мають такі особливості:

- «nосівна стадія» передбачає формування стартового капіталу після підготовки паперового варіанту бізнес-проєкту;

- «стадіï запуску» $є$ початком практичної діяльності та позиціювання на ринку;

- «стадія зростання» характеризується досягненням нормальних (очікуваних) значень основних економічних показників: випуску, продажів, прибутку тощо; 
- «стадія розширення» означає зростання масштабів справи через додаткові інвестиції в персонал, основний капітал, офісні площі тощо, а також отримання високих «інноваційних» прибутків, які компенсують попередні ризики та корелюють 3 унікальністю (інноваційністю) продукту;

- «стадія виходу» пов'язана з завершенням «життєвого циклу» стартапу, що може поєднуватися з набуттям ознак «звичайної» компанії, 3 масовим відтворенням раніше інноваційної ідеї іншими підприємцями, а також з виходом з компанії засновників та продажем пакету акцій, яким вони володіли.

У науковій та публіцистичній літературі послуговуються й іншими класифікаціями етапів «життєвого циклу» стартапів. Попри відмінності підходів, однак, можна констатувати таке:

- стартапи перебирають на себе ризики невизначеності на початкових етапах свого існування;

- ті зі стартапів, які не припиняють свого існування на початкових етапах, на пізніших етапах додають визначеності для інших форм бізнесу та всієї національної економіки.

За результатами аналізу світового досвіду розвитку стартапів дослідники роблять узагальнення, що спираються на незаперечні факти.

По-перше, державна підтримка інноваційної діяльності відіграє визначальну роль у зростанні кількості стартапів та в їх успішному розвиткові. Керівництво ЄС загалом та уряди Німеччини, Франції, Фінляндії, Австрії, Ірландії, Швеції, Норвегії, зокрема, втілюють програми підтримки стартапів. Цим інноваційним підприємствам надаються кредитні та податкові пільги, гранти для студентів, перспективних випускників навчальних закладів, для окремих підприємців, створюється сприятливе середовище для венчурних інвесторів. Нові члени СС Польща, Чехія, Литва, Угорщина - також стали активними учасниками процесу підтримки інноваційного підприємництва [7].

По-друге, політика урядів країн, які є інсайдерами - лідерами та активними діячами інноваційної сфери - має декілька спільних рис. Це чітке розмежування сфер повноважень державних, регіональних i місцевих органів влади, що дозволяє уникнути дублювання функцій, імплементація у світові інноваційні процеси на засадах міжнародної кооперації, включно з трансфером технологій, реформування законодавства під потреби інноваційних підприємств [8].

По-третє, успішними стають стартапи, які створюються у сферах задоволення найбільш актуальних потреб або ті, що такі потреби формують та підтримують. Про це, зокрема, свідчить інформація 3 сайту «StartupRanking» про рейтинг стартапів світу. Ранжування стартапів У рейтингу здійснюється на основі так званої оцінки SR, яка відображає 
важливість стартапу в Інтернеті (оцінка SR Web) і його соціальний вплив (SR Social).

У табл. 2 подано 10 найвідоміших стартапів, за рейтингом «StartupRanking» у 2020 p.

Таблиця 2

Tоп 10 стартапів у світовому рейтингу за «StartupRanking»

\begin{tabular}{|c|c|c|c|c|c|}
\hline Ранг & Стартап & $\begin{array}{l}\text { Засно- } \\
\text { ваний }\end{array}$ & $\begin{array}{l}\text { Оцінка } \\
\text { SR }\end{array}$ & Опис & $\begin{array}{c}\text { Ранг } \\
\text { країни }\end{array}$ \\
\hline 1 & $500 \mathrm{px}$ & 2009 & 89,794 & $\begin{array}{l}\text { Прем'єр-фотографічне співтовариство } \\
\text { для нагромадження кращих зображень } \\
\text { в Інтернеті }\end{array}$ & Канада \\
\hline 2 & Canva & 2012 & 89,645 & $\begin{array}{l}\text { Програмне забезпечення для } \\
\text { графічного дизайну }\end{array}$ & Австралія \\
\hline 3 & Coursera & 2012 & 88,178 & $\begin{array}{l}\text { Безкоштовні онлайн-курси від кращих } \\
\text { університетів }\end{array}$ & США \\
\hline 4 & Duolingo & 2011 & 88,171 & $\begin{array}{l}\text { Безкоштовна мовна освіта для всього } \\
\text { світу }\end{array}$ & Гватемала \\
\hline 5 & Freelancer & 2009 & 88,085 & $\begin{array}{l}\text { Найбільший у світі ринок фрілансингу } \\
\text { та краудсорсингу }\end{array}$ & Австралія \\
\hline 6 & Teespring & 2011 & 87,665 & $\begin{array}{l}\text { Платформа, яка дозволяє кожному } \\
\text { створювати та продавати високоякісні } \\
\text { продукти }\end{array}$ & США \\
\hline 7 & Giphy & 2013 & 87,636 & Анімований пошук у GIF & США \\
\hline 8 & Telegram & 2013 & 87,607 & Додаток з обміну повідомленнями & Рociя \\
\hline 9 & IFTTT & 2010 & 87,382 & $\begin{array}{l}\text { Отримання великих масивів } \\
\text { інформації при поєднання існуючих } \\
\text { онлайн-сервісів - Facebook, Twitter } \\
\text { тощо }\end{array}$ & США \\
\hline 10 & TransferWise & 2010 & 87,362 & $\begin{array}{l}\text { Перекази грошей в Інтернеті, } \\
\text { надсилання грошей за кордон }\end{array}$ & $\begin{array}{l}\text { Велика } \\
\text { Британія }\end{array}$ \\
\hline
\end{tabular}

Докерело: згруповано авторами [9].

За інформацією, поданою в табл. 2, найбільш успішні стартапи у 2020 році діяли у таких сферах, як фото- та графічне редагування, онлайн-курси та платформи для освіти, дистанційної роботи через віддалений доступ, продажу товарів через інтернет-платформи, GIFанімація, створення баз даних про потреби споживачів, грошові онлайн-перекази.

По-четверте, існують типові причини неуспішності стартапів, значна частина яких пов'язана з помилками в управлінні інноваційним бізнесом. Узагальнення щодо цих причин, зроблені компанією «СВ Insights», подано на рис. 5.

Як свідчить інформація, подана на рис. 5, основною причиною «провалу» стартапів - 42\% від загальної кількості - виявилося те, що вони не були спрямовані на задоволення реально існуючих потреб. Звідси випливає висновок, що ідея стартапу не може значно «випереджати» потреби споживачів. 


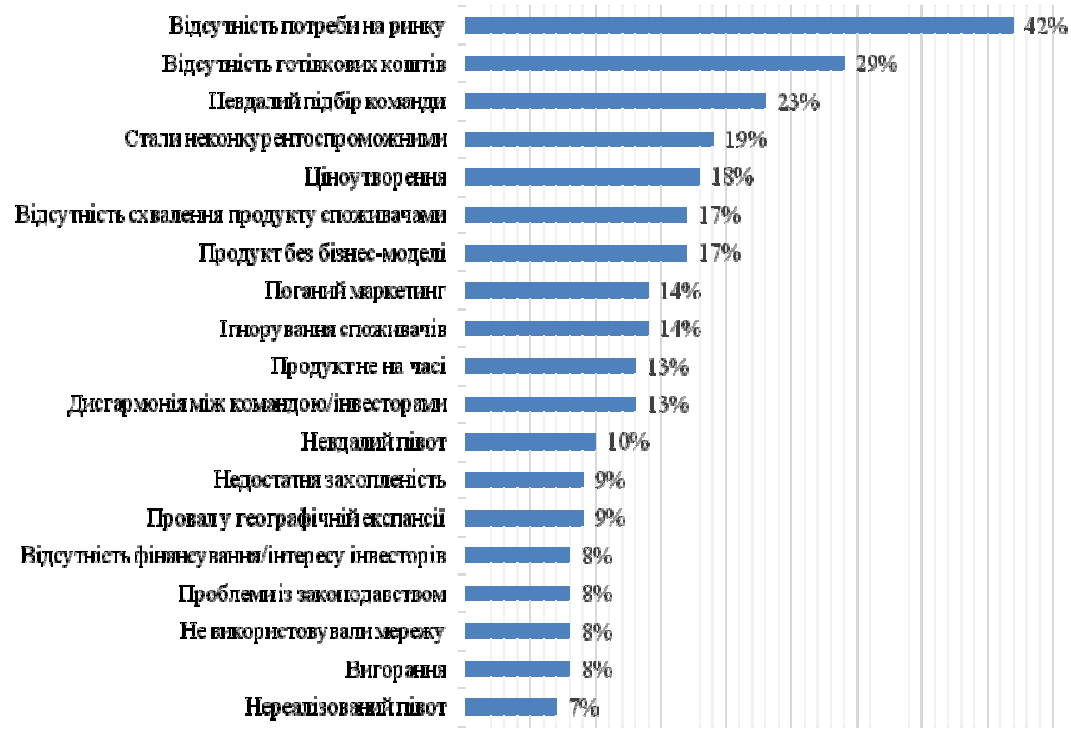

Рис. 5. Визначальні причини невдач стартапів

Джерело: створено авторами самостійно за матеріалами [10].

Сучасна українська економіка не $\epsilon$ економікою інноваційного типу. Країна належить до групи інноваційних аутсайдерів. Однією 3 головних причин такого стану речей, на наш погляд, $є$ інтерес владної верстви суспільства у консервуванні традиційної ресурсно-орієнтованої та не-інноваційної моделі економіки. Попри це, в Україні розвиваються стартапи й сформувався тренд на їх зростання.

Є підстави для таких узагальнень щодо розвитку інноваційного сегменту української економіки та українських стартапів.

Перше. У другій половині 2010-х років відбулося стрімке зростання інвестицій у стартапи. За результатами дослідження Української асоціації венчурного та приватного капіталу (UVCA), динаміка інвестування була такою (рис. 6).

Інформація, подана на рис. 6, свідчить, що в 2017 р. (перший рік помітної стабілізації української економіки) порівняно з 2013 р. (останній рік перед російсько-українською війною) інвестиції в українські стартапи зросли майже в 3 рази. Упродовж одного 2019 р. інвестиції в стартапи збільшилися в 1,5 рази. 


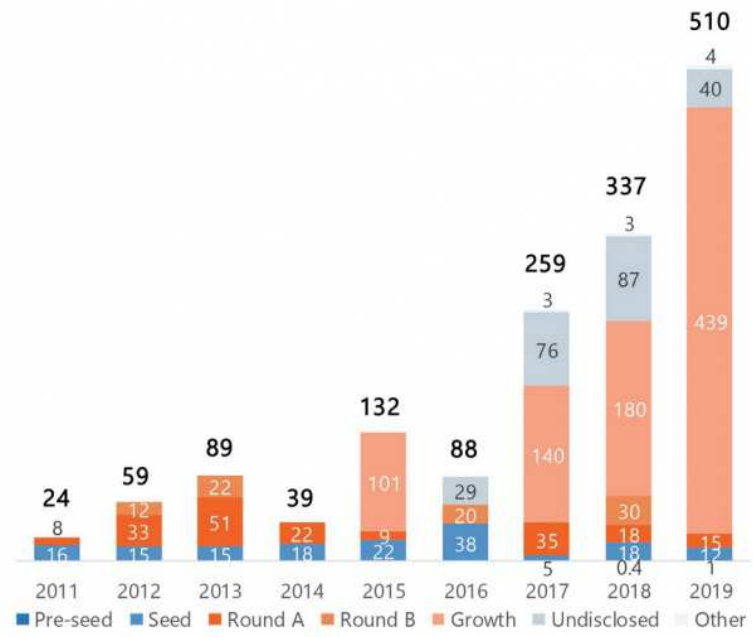

Рис. 6. Інвестиції в українські стартапи за період 2011 - 2019 рр. (млн дол. США)

Джерело: побудовано авторами [11].

Друге. В Україні застосовуються принаймні сім джерел фінансування стартапів, які, за значущістю, ранжуються у такий спосіб $\epsilon[12 ; 13]$ :

- особисті гроші - власні заощадження ініціаторів стартапу;

- гроші друзів та родичів - кошти, отримані в борг у вузькому колі близьких людей з метою організації родинної справи;

- краудфандінг - народне фінансування через спеціалізовані платформи, близьке за змістом до благодійництва заради конструктивної ідеї;

- банківський кредит під розвиток підприємницької ідеї (формально - чинна програма «Доступні кредити 5-7-9\%»);

- бізнес-ангели - поодинокі незалежні інвестори на самих початках розвитку проєкту, іноді за умови участі в управлінні;

- державна участь у фінансуванні (Український фонд стартапів);

- венчурне фінансування - використання коштів вкладників фонду на проєкти з високими ризиками, часто за невигідних для стартапів умов.

На жаль, в Україні такі джерела фінансування стартапів, як державне фінансування, а також за участі венчурних фондів та банків ще не стали визначальними. Саме це відрізняє українську економіку від економік інноваційного типу.

Tpeтє. В Україні загалом створено законодавчу базу для організації інноваційної діяльності та функціонування стартапів. Але їй бракує конкретності, дієвості та політичної волі для реалізації. Основні законодавчі акти подано в табл. 3. 
Таблиия 3

Законодавче поле для діяльності стартапів в Україні

\begin{tabular}{|c|c|c|}
\hline № & Законодавчий акт & Сфера регулювання \\
\hline 1. & $\begin{array}{l}\text { Закон України «Про } \\
\text { інвестиційну діяльність» від } \\
\text { 18.09.1991 р. №1560-XII [14] }\end{array}$ & $\begin{array}{l}\text { Визначає загальні правові, економічні та соціальні } \\
\text { умови інвестиційної діяльності на території України }\end{array}$ \\
\hline 2. & $\begin{array}{l}\text { Закон України «Про } \\
\text { підприємництво» від } 7 \text { лютого } \\
1991 \text { р. №698-XII [15] }\end{array}$ & $\begin{array}{l}\text { Визначає загальні правові, економічні й соціальні } \\
\text { засади підприємницької діяльності (підприємництва) } \\
\text { громадян та юридичних осіб на території України, } \\
\text { встановлює гарантії свободи підприємництва та його } \\
\text { державної підтримки }\end{array}$ \\
\hline 3. & $\begin{array}{l}\text { Закон України «Про режим } \\
\text { іноземного інвестування» від } \\
\text { 19.03.1996 р. №93/96-ВР [16] }\end{array}$ & $\begin{array}{l}\text { Визначає загальні особливості режиму іноземного } \\
\text { інвестування на території України, виходячи з цілей, } \\
\text { принципів і положень законодавства України }\end{array}$ \\
\hline 4. & $\begin{array}{l}\text { Закон України «Про } \\
\text { інноваційну діяльність» від } \\
\text { 04.07.2002 р. №40-IV [17] }\end{array}$ & $\begin{array}{l}\text { Визначає правові, економічні та організаційні засади } \\
\text { державного регулювання інноваційної діяльності в } \\
\text { Україні, встановлює форми стимулювання державою } \\
\text { інноваційних процесів і спрямований на підтримку } \\
\text { розвитку інноваційної економіки України }\end{array}$ \\
\hline 5. & $\begin{array}{l}\text { Закон України «Про наукові } \\
\text { парки» від 25.06.2009 р. } \\
\text { №1563-VI [18] }\end{array}$ & $\begin{array}{l}\text { Регулює правові, економічні, організаційні відносини, } \\
\text { пов’язані зі створенням і функціонуванням наукових } \\
\text { парків, та спрямований на інтенсифікацію процесів } \\
\text { розроблення, впровадження, виробництва } \\
\text { інноваційних продуктів та інноваційної продукції }\end{array}$ \\
\hline 6. & $\begin{array}{l}\text { Закон України «Про авторське } \\
\text { право та суміжні права» від } \\
\text { 23.12.1993 р. №3792-XII [19] }\end{array}$ & $\begin{array}{l}\text { Охороняє особисті (немайнові) й майнові права авторів } \\
\text { та їх правонаступників, пов'язані зі створенням і } \\
\text { використанням творів науки, літератури й мистецтва } \\
\text { (авторське право), і права виконавців, виробників } \\
\text { фонограм та організацій мовлення (суміжні права) }\end{array}$ \\
\hline 7. & $\begin{array}{l}\text { Закон України «Про охорону } \\
\text { прав на винаходи і корисні } \\
\text { моделі» від } 15.12 .1993 \text { р. } \\
\text { №3687-XII [20] }\end{array}$ & $\begin{array}{l}\text { Регулює відносини, що виникають у зв’язку з набуттям } \\
\text { і здійсненням права інтелектуальної власності на } \\
\text { винаходи та корисні моделі в Україні }\end{array}$ \\
\hline 8. & $\begin{array}{l}\text { Закон України «Про охорону } \\
\text { прав на знаки для товарів і } \\
\text { послуг» від 15.12.1993 p. } \\
\text { №3689-XII [21] }\end{array}$ & $\begin{array}{l}\text { Регулює відносини, що виникають у зв'язку з набуттям } \\
\text { і здійсненням права власності на знаки для товарів та } \\
\text { послуг в Україні }\end{array}$ \\
\hline 9. & $\begin{array}{l}\text { Закон України «Про захист } \\
\text { персональних даних» від } \\
\text { 01.06.2010 p. №2297-VI [22] }\end{array}$ & $\begin{array}{l}\text { Регулює правові відносини, пов’язані із захистом і } \\
\text { обробкою персональних даних, та спрямований на } \\
\text { захист основоположних прав і свобод людини й } \\
\text { громадянина, зокрема права на невтручання в особисте } \\
\text { життя, у зв'язку з обробкою персональних даних }\end{array}$ \\
\hline
\end{tabular}

Джерело: сформовано авторами за матеріалами [23; 24].

3 аналізу українського законодавства випливає, що, створюючи загальні умови підприємницької діяльності та умови інвестування, воно не врегульовує спеціальні умови діяльності стартапів. Останній 3 наведених нормативних документів прийнято 10 років тому. Тому нормативна база не віддзеркалює сучасні умови та особливі потреби підприємців-інноваторів. 
Четверте. В Україні в 2019 р. створено державою спеціальний орган, який покликаний опікуватися діяльністю стартапів - Український фонд стартапів (УФС). Це може бути потрактовано як факт здійснення реальних кроків на шляху підтримки інноваційної діяльності.

Про цілі та пріоритети УФС можна робити висновки з інформації щодо формальних ознак фонду, напрямків фінансування та обсягу коштів, якими він оперує.

Формальні характеристики УФС презентовано в табл. 4.

Таблиия 4

Основні характеристики Українського фонду стартапів

\begin{tabular}{|c|c|}
\hline $\begin{array}{c}\text { Перелік } \\
\text { характеристик }\end{array}$ & Зміст характеристик \\
\hline Форма власності & державна \\
\hline Ініціатор створення & Кабінет Міністрів України \\
\hline Місія фонду & $\begin{array}{l}\text { підтримка інноваційних проєктів та допомога найталановитішим } \\
\text { українським підприємцям у створенні успішних глобальних } \\
\text { компаній }\end{array}$ \\
\hline $\begin{array}{l}\text { Умови } \\
\text { фінансування }\end{array}$ & $\begin{array}{l}\text { - фінансування лише українського бізнесу; } \\
\text { - у формі грантів, а не за рахунок участі в капіталі (від } 25 \text { до } \\
50 \text { тис. дол.); } \\
\text { - фінансування компаніям на початкових стадіях розвитку (рre- } \\
\text { seed та seed); } \\
\text { - фінансування перспективних та інноваційних ідей технологічних } \\
\text { стартапів, які демонструють високий потенціал глобального } \\
\text { комерційного успіху }\end{array}$ \\
\hline Процес відбору & $\begin{array}{l}\text { на конкурсній основі: компанії оцінюються та обираються радою } \\
\text { незалежних інвестиційних експертів }\end{array}$ \\
\hline Цілі фонду & $\begin{array}{l}\text { - підтримка інновацій; } \\
\text { - заохочення підприємництва; } \\
\text { - розвиток економіки; } \\
\text { - збільшення інвестицій; } \\
\text { - створення робочих місць; } \\
\text { - підвищення обізнаності }\end{array}$ \\
\hline Цільові сектори & $\begin{array}{l}\text { - штучний інтелект (AI); } \\
\text { - доповнена реальність (AR/VR) } \\
\text { - великі дані (BigData); } \\
\text { - блокчейн; } \\
\text { - кібербезпека; } \\
\text { - захист (Defence); } \\
\text { - медицина та охорона здоров’я; } \\
\text { - подорожі; } \\
\text { - фінансові технології (FinTech); } \\
\text { - освітні технології (EdTech); } \\
\text { - робототехніка; } \\
\text { - професійні послуги; } \\
\text { - програмне забезпечення як послуга (SaaS); } \\
\text { - виробництво; } \\
\text { - електронна комерція інтернет речей (IoT) }\end{array}$ \\
\hline
\end{tabular}

Джерело: складено авторами за [25]. 
За інформацією 3 табл. 5, Український фонд стартапів має на меті вдосконалення не лише спеціальних умов для розвитку стартапів, а й загальних умов розвитку підприємництва. Незаперечним позитивом його діяльності $є$ прозорий та публічний конкурс проєктів. Фонд фінансує кожний стартап, який виграв конкурс та перебуває на ранніх стадіях розвитку, в сумі 25 тис. дол. Стартап, що функціонує на більш пізніх стадіях, може отримати від фонду 50 тис. дол. Відтак, один стартап, який не припинив діяльності й демонструє зростання, може мати підтримку в сумі 75 тис. дол.

У 2019 - 2020 рр. Фонд фінансував такі українські стартапи на початкових етапах їх становлення (табл. 5).

Таблиия 5

Українські стартапи, які фінансовані у 2019 - 2020 рр. Українським фондом стартапів (у сумі до 25 тис. дол. США)

\begin{tabular}{|c|c|c|c|}
\hline № & $\begin{array}{c}\text { Назва } \\
\text { компанії }\end{array}$ & Зміст стартапу & $\begin{array}{c}\text { Напрям } \\
\text { фінансування } \\
\text { УФС } \\
\end{array}$ \\
\hline 1. & iCorn & $\begin{array}{l}\text { Платформа об’єднує фермерів, покупців } \\
\text { агропродукції, транспортні компанії, елеватори, } \\
\text { лабораторії, банки та страхові компанії, пов'язані } 3 \\
\text { агробізнесом }\end{array}$ & $\begin{array}{l}\text { Штучний інтелект, } \\
\text { блокчейн, } \\
\text { агротехнології, } \\
\text { Fintech / Legaltech }\end{array}$ \\
\hline 2. & $\begin{array}{l}\text { Caretech } \\
\text { Human }\end{array}$ & $\begin{array}{l}\text { Неперервний автоматичний моніторинг здоров'я та } \\
\text { виявлення хвороб на ранніх стадіях у домашніх умовах }\end{array}$ & $\begin{array}{l}\text { Охорона здоров'я, } \\
\text { штучний інтелект }\end{array}$ \\
\hline 3. & Cittart & $\begin{array}{l}\text { Маркетплейс, розроблений як мобільний додаток, } \\
\text { де будь-який художник або митець зможе легко } \\
\text { розмістити свій артоб'єкт для продажу, а покупець - } \\
\text { оформити замовлення }\end{array}$ & $\begin{array}{c}\text { Big data, } \\
\text { блокчейн, } \\
\text { роздрібна торгівля }\end{array}$ \\
\hline 4. & Sprybuild & $\begin{array}{l}\text { 3D-принтери, полімери та програмне забезпечення } \\
\text { для промислових споживачів, що дозволяє дешево } \\
\text { та швидко виготовляти серійні вироби }\end{array}$ & Промисловість \\
\hline 5. & IOON & $\begin{array}{l}\text { Перший портативний пристрій, що будь-де і будь- } \\
\text { коли перетворює звичайну воду на ефективний у } \\
\text { боротьбі з мікробами санітайзер }\end{array}$ & Охорона здоров'я \\
\hline 6. & Dooozen.io & $\begin{array}{l}\text { Онлайн-сервіс, покликаний звільнити від рутинної } \\
\text { роботи та підвищити продуктивність усіх, хто } \\
\text { активно працює } 3 \text { мережею LinkedIn }\end{array}$ & Медіа та реклама \\
\hline 7. & BioBin & $\begin{array}{l}\text { Мобільний додаток для зменшення впливу на } \\
\text { навколишнє середовище за рахунок кращого } \\
\text { управління споживанням та відходами }\end{array}$ & $\begin{array}{l}\text { Енергетика та } \\
\text { екологія }\end{array}$ \\
\hline 8. & BIOsens & $\begin{array}{l}\text { Перший у світі пристрій, який автоматизує підготовку } \\
\text { зразків, аналіз та збереження результатів у хмарі, } \\
\text { випробування поза лабораторією, але з лабораторною } \\
\text { точністю }\end{array}$ & Агротехнології \\
\hline 9. & Skyworker & $\begin{array}{l}\text { Продукт, який пришвидшує найм IT-спеціалістів у } \\
10 \text { разів з допомогою побудови власної мережі } \\
\text { зв'язків онлайн }\end{array}$ & Big data \\
\hline 10. & Pytag & $\begin{array}{l}\text { Платформа для торгівлі зерном, яка використовує } \\
\text { унікальні алгоритми для збору та обробки всіх } \\
\text { доступних цифрових даних про ринок торгівлі зерном }\end{array}$ & Big data \\
\hline
\end{tabular}

Джерело: [25] інформаиійні дані щзодо профінансованих стартапів УФС станом на 05.07.2020. 
Як свідчить інформація 3 табл. 5, Український фонд стартапів фінансував перші етапи становлення стартапів, діяльність яких була пов'язана з управлінням агробізнесом, 3 охороною здоров'я, з екологією та створенням великих баз даних - Data Base.

На більш пізніх етапах розвитку стартапів Українським фондом стартапів підтримано (в обсязі 50 тис. дол. США) такі підприємтсва (табл. 6)

Таблиия 6

\section{Українські стартапи, які фінансовані у 2019 - 2020 рр.} Українським фондом стартапів (у сумі 50 тис. дол. США)

\begin{tabular}{|c|c|c|c|}
\hline № & $\begin{array}{l}\text { Назва } \\
\text { компанії }\end{array}$ & Зміст стартапу & $\begin{array}{c}\text { Напрям } \\
\text { фінансування } \\
\text { УФС }\end{array}$ \\
\hline 1. & Norm & $\begin{array}{l}\text { Пристрій із вбудованим живленням та технологією } \\
\text { машинного навчання для ефективної і здорової } \\
\text { роботи }\end{array}$ & $\begin{array}{c}\text { Енергетика та } \\
\text { екологія, } \\
\text { штучний інтелект }\end{array}$ \\
\hline 2. & NuWork & CRM-система управління наймом працівників & $\begin{array}{c}\text { Big data, } \\
\text { штучний інтелект }\end{array}$ \\
\hline 3. & FlashBeats & $\begin{array}{l}\text { Мобільний додаток для створення світлових шоу } \\
\text { на музичних та спортивних подіях }\end{array}$ & Спосіб життя \\
\hline 4. & FINMAP & $\begin{array}{l}\text { Онлайн-сервіс для фінансового обліку в малому } \\
\text { та мікробізнесі }\end{array}$ & $\begin{array}{l}\text { Fintech/Legaltech, } \\
\text { освітні технології, } \\
\text { роздрібна торгівля }\end{array}$ \\
\hline 5. & Allzap & $\begin{array}{l}\text { Платформа для створення інтернет-магазинів } 3 \\
\text { продажу автозапчастин та маркет-плейса }\end{array}$ & $\begin{array}{l}\text { Медіа та реклама, } \\
\text { роздрібна торгівля }\end{array}$ \\
\hline 6. & GeoDesign & $\begin{array}{l}\text { Аналітичний онлайн-сервіс, що надає інформацію } \\
\text { про переваги та ризики відкриття магазину/кафе/ } \\
\text { перукарні або інших закладів залежно від локації }\end{array}$ & $\begin{array}{c}\text { Big data, } \\
\text { роздрібна торгівля }\end{array}$ \\
\hline 7. & FRAMIORE & $\begin{array}{l}\text { Формування бренду жіночого одягу з власним } \\
\text { швейним виробництвом та R\&D центром } 3 \\
\text { дослідження, розробки й інновацій текстильних } \\
\text { виробів та технологій }\end{array}$ & $\begin{array}{c}\text { Енергетика та } \\
\text { екологія, } \\
\text { промисловість, } \\
\text { роздрібна торгівля }\end{array}$ \\
\hline 8. & $\mathrm{BIOC}$ & $\begin{array}{l}\text { Технологія нанополімеризації, що дозволяє на } \\
\text { молекулярному рівні зв'язати крохмаль та отримати } \\
\text { біокомпаунд (або біопластик) з високими фізико- } \\
\text { механічними властивостями }\end{array}$ & Промисловість \\
\hline 9. & Cardiolyse & $\begin{array}{l}\text { Платформа для автоматичної інтерпретації } \\
\text { електричних сигналів серця у стані спокою та } \\
\text { Холтер-моніторингу медичного рівня для } \\
\text { визначення } 19 \text { типів аритмій і точного виявлення } \\
\text { більшості аномалій серця } \\
\end{array}$ & Охорона здоров’я \\
\hline 10. & Mate academy & Онлайн-університет IT-професій & Освітні технологіі \\
\hline 11. & ChoiZY & $\begin{array}{l}\text { Профорієнтаційна онлайн-платформа, що допомагає } \\
\text { підліткам обрати професію, а фахівцям - поділитися } \\
\text { досвідом із молоддю }\end{array}$ & Освітні технології \\
\hline 12. & Legal Nodes & $\begin{array}{l}\text { Юридичний маркетплейс, який допомагає } \\
\text { технологічному бізнесу вирішувати юридичні } \\
\text { питання в різних країнах світу }\end{array}$ & Освітні технологіі \\
\hline 13. & SolarGaps & $\begin{array}{l}\text { Система жалюзі із сонячними елементами, які } \\
\text { генерують електроенергію }\end{array}$ & $\begin{array}{c}\text { Енергетика та } \\
\text { екологія }\end{array}$ \\
\hline
\end{tabular}


Продовження табл. 6

\begin{tabular}{|l|l|l|c|}
\hline 14. & $\begin{array}{l}\text { TOВ } \\
\text { СМАРТ- } \\
\text { МАК }\end{array}$ & $\begin{array}{l}\text { Розробка, виробництво та реалізація продуктів і } \\
\text { сервісів для моніторингу споживання будь-яких } \\
\text { ресурсів }\end{array}$ & $\begin{array}{c}\text { Вig data, } \\
\text { енергетика та } \\
\text { екологія }\end{array}$ \\
\hline 15. & $\begin{array}{l}\text { Agrifinance } \\
\text { Online }\end{array}$ & $\begin{array}{l}\text { Формування мережі зв’язків учасників } \\
\text { сільськогосподарського ринку України через } \\
\text { інтегровану та прозору онлайн-екосистему }\end{array}$ & $\begin{array}{l}\text { Fintech / Legaltech, } \\
\text { aгротехнології }\end{array}$ \\
\hline 16. & HarvesTrack & $\begin{array}{l}\text { Нardware та Software (ІоТ) рішення для контролю } \\
\text { процесу збору врожаю та попередження крадіжки } \\
\text { зерна під час жнив }\end{array}$ & Агротехнології \\
\hline 17. & AeroDrone & $\begin{array}{l}\text { Безпілотні літаки з високим корисним } \\
\text { навантаженням та довгою тривалістю польоту }\end{array}$ & Агротехнології \\
\hline 18. & FieldBI & $\begin{array}{l}\text { Комплексна аналітично-експертна система для } \\
\text { покращення рішень для всіх учасників ринку }\end{array}$ & Агротехнології \\
\hline 19. & Unicorn Nest & $\begin{array}{l}\text { Пошук найбільш релевантних інвесторів на } \\
\text { основі власної бази інвесторів та формування } \\
\text { стандарту для фандрейзингу }\end{array}$ & Fintech / Legaltech \\
\hline 20. & Правомен & $\begin{array}{l}\text { Автоматизований помічник з побутових юридичних } \\
\text { питань, включно з формуванням документів та } \\
\text { роз’ясненням можливостей е-сервісів, створених } \\
\text { державою }\end{array}$ & Fintech / Legaltech \\
\hline
\end{tabular}

Джерело: [25] інформаџійні дані щзодо профінансованих стартапів УФС станом на 05.07.2020.

Аналіз стартапів, підтриманих Фондом на етапах їх більш пізнього існування, свідчить про достатньо широке коло пріоритетів. Воно охоплює онлайн-сервіси, агробізнес, екологію, медицину, енергетичну сферу, правове консультування та електронне врядування тощо.

Загалом, з часу заснування у 2019 р. до середини 2020 р. Українським фондом стартапів фінансовано 30 технологічно інноваційних підприємств на загальну суму 1,25 млн дол. США. Причому, за кількістю фінансованих підприємств та обсягом фінансування, перевага надана таким сферам: аграрним технологіям (5 стартапів та 225 тис. дол. США), енергетиці та екології (4 та 175, відповідно), великим базам даних - Big Data (4 та 150, відповідно).

Аналізуючи основні вектори спрямування коштів та потенціал державного фонду підтримки стартапів, маємо підстави для таких узагальнень:

- на жаль, ні в переліку цілей державного фонду, ні в переліку фактично фінансованих стартапів немає тих, які безпосередньо пов'язані 3 військово-промисловим комплексом (ВПК). Останнє $є$ неприродним для країни, що перебуває у стані війни;

- не презентовано напрямок кібербезпеки, актуальність якого зростає в час збільшення економічної невизначеності, зростання кількості кібератак на різні портали та бази даних, включно з державними; 
- загальна сума коштів фонду є достатньо малою й такою, що не може помітно змінити ситуацію в інноваційній сфері.

П'яте. Попри те, що Україна залишається інноваційним аутсайдером і не має необхідної підтримки для розвитку стартапів, інтелектуальний та людський потенціал країни створює передумови для розвитку інноваційного підприємництва. Основні українські стартапи виникають у сфері IT-технологій. За оцінкою «StartupRanking», провідними в Україні в 2019-2020 рр. були 10 стартапів. Вони спеціалізуються на створенні та просуванні вебсайтів, оптимізації й тестуванні для розробників, на програмному забезпеченні онлайнсервісів. Україна з кожним роком посилює свої позиції на міжнародній IT-арені. За висновками українських експертів з UVCA, країна стає $\mathrm{R} \& \mathrm{D}$-хабом для іноземних компаній. В Україні формуються передумови для так званих «інноваційних проривів». Останні створюють образ майбутнього та сприяють його формуванню вже сьогодні. За даними компанії «ADVICE Audit Consulting Group», в Україні створено стартапи, які можуть змінити світ. До таких рушіїв змін належать [26]:

- Carbominer - стартап з вилучення вуглекислого газу з повітря 3 метою його продажу промисловим тепличним комплексам;

- Ecotyre - стартап з переробки спрацьованих автомобільних гумових покришок та металевих домішок, які вони містять;

- Atmosphere - стартап 3 точного прогнозування погоди в межах, що не перевищують 200 метрів від споживача сервісу;

- Minect.ai - стартап з технологією дистанційного розмінування територій Донбасу, замінованих окупантами, за допомогою взаємодії дронів і обладнання для виявлення вибухівки - радарів грунту, металодетекторів, тепловізорів тощо;

- Greenbin.app - стартап, який забезпечує низькі витрати переробки сміття, за рахунок використання привабливої системи стимулів для споживачів продукції;

- Seadora - стартап, спрямований на порятунок Світового океану шляхом мінімізації відходів рибопродуктів та безпосереднє заохочення рибалок.

Існує перелік українських стартапів, здатних закладати сьогодні основи моделі привабливого та сприятливого для людей майбутнього. До таких належать п’ятнадцять стартапів (табл. 7).

Наведений у табл. 7 перелік стартапів стосується екології, добробуту і формування привабливої перспективи, впевненості у майбутньому та економічної й соціальної визначеності. Йдеться не лише про українських громадян, а й про громадян інших країн, оскільки йдеться про вирішення глобальних екологічних проблем. 


\section{П'ятнадцять українських екостартапів світового значення}

\begin{tabular}{|c|l|l|}
\hline № & \multicolumn{1}{|c|}{$\begin{array}{c}\text { Назва } \\
\text { екостартапу }\end{array}$} & \multicolumn{1}{c|}{ Зміст діяльності } \\
\hline 1. & Recycle Map & Інтерактивна мапа пунктів утилізації різних типів відходів \\
\hline 2. & FoodBIOPack & Біорозкладне та їстівне пакування, посуд та столові прибори \\
\hline 3. & Ecoisme & Система економії електроенергії \\
\hline 4. & RE-leaf PAPER & Папір із опалого листя \\
\hline 5. & Effa & Одноразова зубна щітка з переробленого паперу \\
\hline 6. & Re-beau & Прикраси з переробленого пластику \\
\hline 7. & Flushwave & Система повторного використання технічної води \\
\hline 8. & Go Tо-U & $\begin{array}{l}\text { Міжнародна платформа з безкоштовними зарядними станціями для } \\
\text { електромобілів }\end{array}$ \\
\hline 9. & SolarGaps & Жалюзі з сонячними панелями \\
\hline 10. & Stock-factory & $\begin{array}{l}\text { Онлайн-платформа збуту проблемних товарів (пошкоджена упаковка, } \\
\text { наближається термін придатності), що сприяє скороченню обсягів } \\
\text { знищення товарів у торгівельних мережах }\end{array}$ \\
\hline 11. & UGrid & $\begin{array}{l}\text { Сервіс побудови енергетичних мікромереж, що допоможе скоротити } \\
\text { використання викопних джерел енергії та уникнути переплати за } \\
\text { енергопостачання }\end{array}$ \\
\hline 12. & TOKA & Мережа електрозаправок \\
\hline 13. & Nuka & Вічний блокнот та вічний олівець \\
\hline 14. & Water Cloud UA & Пристрій для забору води з повітря \\
\hline 15. & Jollylook & $\begin{array}{l}\text { Екологічно чиста фотокамера з переробленого паперу та картону } \\
\text { для миттєвих знімків }\end{array}$ \\
\hline
\end{tabular}

Джерело: систематизовано авторами за [27-29].

Шосте. Україна активізує співпрацю з міжнародними інститутами, причетними до стимулювання інноваційної діяльності та підтримки стартапів. До прикладу, в 2020 р. Український фонд стартапів узяв участь у формуванні спільної онлайн-платформи 3 підтримки ефективних рішень для подолання світової кризи з фокусом на Східну Європу AC LAB21. Уже підписано Меморандум про співпрацю з міжнародним венчурним фондом Solid5, бізнес-акселератором FeelGoodLabs, Центром підприємництва Українського католицького університету, іншими зацікавленими в розвитку інновацій в Україні учасниками. Міжнародна кооперація відкриває нові можливості для українських стартапів, що не отримали підтримки від українського уряду, мати таку підтримку від міжнародних організацій [25]. Для використання переваг міжнародної співпраці мають бути подолані чинні перепони на шляху отримання та використання українськими підприємцями іноземних коштів для інноваційної діяльності.

Сьоме. В українській економіці й суспільстві сформувалося багато причин, які стримують інноваційну діяльність. На наш погляд, SWOT-аналіз умов для розвитку українських стартапів мав би показати переважання обмежень над факторами сприяння. В усіх дослідженнях 
3 питань інноваційної діяльності виокремлюються ці обмеження. На жаль, поки що відсутні дослідження з обгрунтування ієрархії чинників стримування. Саме таке «негативне рейтингування» факторів впливу могло б створити основу для прийняття обгрунтованих управлінських рішень. 3 урахуванням думки інших дослідників, ми формулюємо припущення про таку ієрархію найважливіших факторів стримування інноваційної діяльності:

- слабкість (обмеженість ресурсів, неструктурованість тощо) українського інвестиційного ринку [30];

- брак державної підтримки інновацій через несформованість інноваційної політики [31] та відсутність політичної волі для ііі здійснення;

- недбале ставлення до ресурсного, насамперед кваліфікованого кадрового потенціалу країни [32];

- незахищеність права власності загалом та права інтелектуальної власності зокрема [33].

3 огляду на існування багатьох факторів стримування інновацій та відсутність послідовної інноваційної політики українських урядів, набувають актуальності дослідження в царині обгрунтування доцільних інструментів стимулювання інноваційної діяльності. На наш погляд, заслуговують на увагу та схвалення рекомендації із застосування таких конкретних інструментів стимулювання [34]:

- «картографування» украӥнської стартап-екосистеми, що передбачатиме створення державного відкритого інтернет-порталу 3 усією необхідною інформацією для підприємців, дослідників, інвесторів та інших зацікавлених в інноваціях осіб;

- приватно-державне партнерство у забезпеченні необхідного рівня освіченості та інтеграції підприємців у міжнародні мережі та спільноти для використання інноваційного досвіду;

- поєднання освіти у сфері IT-технологій та підприємництва для здобуття і використання «цифрових навичок» у практичній діяльності;

- використання стартап-віз - дозволів на проживання для іноземців-ініціаторів стартапів;

- менторські (навчальні, освітні) програми для підприємців 3 метою передачі інноваційного досвіду на постійній основі.

\section{Висновки:}

За результатами дослідження можна зробити такі узагальнення:

- осмислення впливу інноваційного підприємництва та його форми - стартапів - на визначеність національної економіки спирається на усвідомлення взаємозв'язку таких понять (явищ), як: інноваційна діяльність - інноваційне підприємництво - стартапи - інноваційна національна модель розвитку. Віддзеркаленням інноваційної моделі розвитку $\epsilon$ інноваційна політика уряду (держави) 3 властивими їй цілями, пріоритетами та інструментами впливу; 
- характерними інструментами реалізації інноваційної моделі розвитку країнами-інноваційними інсайдерами стають: стабільна частка інноваційних витрат у державному бюджеті, активна діяльність 3 фінансування стартапів венчурними фондами та комерційними банками, постійна участь у міжнародній кооперації в інноваційній сфері та в трансфері технологій. Роль згаданих інструментів сприяння інноваціям не стала вирішальною в українській моделі інноваційної діяльності;

- стартап, як форма інноваційного підприємництва, вирізняється 3-поміж інших форм такими властивостями, як: виникнення у зв'язку з ідеєю принципово нових продукту, послуги, технології, низька ймовірність успішності та значні ризики припинення діяльності, брак інвестиційних ресурсів, спрямованість на швидке зростання та швидке опанування ринку. Саме ці ознаки й стають визначальними при оцінюванні впливу стартапів на економічну невизначеність;

- існують, як мінімум, три напрямки впливу інноваційного підприємництва (стартапів) на економічну невизначеність: а) стартапи перебирають на себе високі ризики інвестування й виконують роль амортизатора для іншого (неінноваційного підприємництва) при масовому тиражуванні інноваційних ідей, б) стартапи виникають та функціонують у сферах, пов'язаних 3 глобальними проблемами у сферах екології, енергетики, охорони здоров'я, стан яких загрожує людству, та забезпечують їх повне або часткове вирішення, в) завдяки стартапам стає зрозумілішим і більш осяжним образ майбутнього, у творенні якого вони беруть безпосередню участь уже сьогодні;

- обмеження інноваційної діяльності, пасивність (бездіяльність) держави в інноваційній сфері або нерезультативна імітація активності органами центральної та місцевої влади означає збільшення масштабів невизначеності національної економіки. За умови політичної волі, український уряд мав би розробити і реалізувати стратегію формування так званої «стартап-екосистеми України» з елементами впливу, вже апробованими в країнах з інноваційною моделлю розвитку.

\section{Лimepamypa:}

1. Горфінкель В. Я. Інноваційне підприємництво. 2015. URL : https://stud.com.ua/21714/ekonomika/innovatsiyne_pidpriyemnitstvo_dosvi d_zarubizhnih_krayin\#49.

2. Blank S. What Founders Need to Know: You Were Funded for a Liquidity Event. Start Looking. 2016. URL : https://steveblank.com/ category/venture-capital.

3. Paul Graham. Before the Startup. 2014. URL : http://www.paulgraham.com/before.html.

4. Рис Э. Бизнес с нуля: Метод Lean Startup для быстрого тестирования идей и выбора бизнес-модели. Москва : Альпина Паблишер, 2012. $253 \mathrm{c}$. 
5. Бланк С., Дорф Б. Священна книга стартапера. Як збудувати успішну компанію / Пер. 3 англ. Н. Валевська. Київ : Наш формат, 2019. $512 \mathrm{c}$.

6. Офіційний вебсайт Про бізнес. Що таке стартап (startup). URL : https://pro-biznes.com.ua/statt-pro-bznes/shho-take-startap-startup.html.

7. Ніщимний В. О. Правові аспекти законодавчого регулювання діяльності стартап-компаній в Україні. URL : https://www.businesslaw. org.ua/pravovi-aspekty-startup/.

8. Жемба А. Й. Світові тенденції впливу інноваційних факторів на економічний розвиток країн в умовах глобалізації. Наукові записки. Серія «Економіка». 2013. Вип. 21. С.16-19.

9. Сайт рейтингу стартапів «StartupRanking». URL : https://www.startupranking.com.

10. The Top 20 Reasons Startups Fail. CB Insights: веб-сайт. URL: https://www.cbinsights.com/research/startup-failure-reasons-top/.

11. Ukrainian Venture Capital and Private Equity Overview 2019. URL : https://www2.deloitte.com/ua/en/pages/press-room/press-release/2020/ investments-into-startups-2019.html\#.

12. Воронцовський В. Стартап - що це таке: визначення та значення терміна, етапи розвитку Startup-проекту + ТОП-10 кращих ідей для стартапу з мінімальними вкладеннями. 22.05.2017. URL : https://itstatti.in.ua/zarobitok-v-interneti/161-startap-shcho-tse-take.html.

13. Що таке стартап простими словами. 29.11.2018. URL : https://uk.binaroption.com/stati/590-chto-takoe-startap-prostymi-slovami.

14. Про інвестиційну діяльність : Закон України від 18.09.1991 р. №1560-XII. URL : https://zakon.rada.gov.ua/laws/show/1560-12\#Text.

15. Про підприємництво : Закон України від 7 лютого 1991 р. №698-XII. URL : https://zakon.rada.gov.ua/laws/show/698-12\#Text.

16. Про режим іноземного інвестування : Закон України від 19.03.1996 p. №93/96-BP. URL : https://zakon.rada.gov.ua/laws/show/93/ 96-\%D0\%B2\%D1\%80\#Text.

17. Про інноваційну діяльність : Закон України від 04.07.2002 p. №40-IV. URL : https://zakon.rada.gov.ua/laws/show/40-15\#Text.

18. Про наукові парки : Закон України від 25.06.2009 р. №1563VI. URL : https://zakon.rada.gov.ua/laws/show/1563-17\#Text.

19. Про авторське право та суміжні права : Закон України від 23.12.1993 p. №3792-XII. URL : https://zakon.rada.gov.ua/laws/show/379212\#Text.

20. Про охорону прав на винаходи і корисні моделі : Закон України від 15.12.1993 р. №3687-XII. URL : https://zakon.rada.gov.ua/ laws/show/3687-12\#Text.

21. Про охорону прав на знаки для товарів і послуг : Закон України від 15.12.1993 р. №3689-XII. URL : https://zakon.rada.gov.ua/ laws/show/3689-12\#Text. 
22. Про захист персональних даних : Закон України від 01.06.2010 p. №2297-VI. URL : https://zakon.rada.gov.ua/laws/show/229717\#Text.

23. Бояринова К. О., Копішинська К. Особливості законодавчого регулювання діяльності стартап-компаній в Україні. Економічний вісник НТУУ «КПI». 2017. №14. С. 393-398.

24. Ніщимний B. О. Правові аспекти законодавчого регулювання діяльності стартап-компаній в Україні. URL : https://www.businesslaw.org.ua/pravovi-aspekty-startup/.

25. Український фонд стартапів. URL : https://usf.com.ua.

26. Лучшие украинские стартапы 2020 TOP Startups, которые изменят Mир URL : https://ua-advice.com/luchshie-ukrainskie-startapy-2020/.

27. 15 українських екостартапів, які підкорюють світ. 23.08.2019. URL : https://www.sfii.gov.ua/15-українських-екостартапів-які-підкор/.

28. Моісеєва М., Голіната А. 15 українських еко-стартапів, які підкорюють світ. 28.02.2019. URL : https://ukrainian.voanews.com/a/ uspishni-ukrainski-ekolohichni-startapy/4794604.html.

29. Проєкт студента КНУ став одним 3 переможців University Startup World Cup 2019. 2019. URL : http://www.univ.kiev.ua/news/ 10695.

30. Вишневецький I. Українські стартапи як надія української економіки URL : https://biz.censor.net.ua/columns/3140403/ukransk_startapi_ yak_nadya_ukransko_ekonomki.

31. Мацкевич Ю. І. Проблеми та перспективи інноваційного розвитку підприємництва в Україні. Теорія та практика управління суб'єктами підприємниитва : колект. моногр. / За заг. ред. Т. В. Гринько. Дніпро : Видавець Біла К. О., 2020. 440 с. С. 195-202.

32. Яковенко В. С. Організаційно-інфраструктурне забезпечення екосистеми стартапів в Україні. Теорія та практика управління суб'єктами підприємництва : колект. моногр. / За заг. ред. Т. В. Гринько. Дніпро : Видавець Біла К. О., 2020. 440 с. С. 379-386.

33. Ніщимний В. О. Правові аспекти законодавчого регулювання діяльності стартап-компаній в Україні. URL : https://www.businesslaw.org. ua/pravovi-aspekty-startup/.

34. Дослідження розвитку екосистем в контексті реалізації стартапів в Україні. Нова хвиля. URL : https://news.ztu.edu.ua/wp-content/ uploads/2019/03/nova-hvylya-1.pdf. 


\title{
СОЦІАЛЬНЕ ПІДПРИСМНИЦТВО ЯК ІНСТРУМЕНТ СОЦІАЛЬНОЇ ІНКЛЮЗІЇ В УМОВАХ ЕКОНОМІЧНОЇ НЕВИЗНАЧЕНОСТІ
}

\author{
Красота Олена Вадимівна, \\ кандидат економічних наук, доцент, \\ дочент кафедри економічної теорії, макро- і мікроекономіки, \\ Київський національний університет імені Тараса Шевченка, \\ ORCID: http://orcid.org/0000-0001-8840-3119, \\ Андрєєва Віма Анатоліївна, \\ кандидат економічних наук, дочент, \\ доцент кафедри теоретичної та прикладної економіки, \\ ВН3 «Університет економіки та права «КРОК», \\ ORCID: https://orcid.org/0000-0002-6357-3063
}

Анотація. В умовах посилення економічної невизначеності, коли держава демонструє обмежені можливості виконання притаманних ій функцій, виникає необхідність нових підходів до вирішення соціальних проблем. Таким новим підходом може ставати соціальна інклюзія, а одним з ії ефективних інструментів - соціальне підприємництво. Саме цій проблемі - використанню соціального підприємництва в інтересах соціальної інклюзії для обмеження економічної невизначеності присвячено цей розділ.

Ключові слова: соціальна інклюзія/ексклюзія, соціальна політика, соціальне підприємництво, незахищені верстви суспільства.

Українське суспільство продовжує шукати відповіді на виклики, пов'язані 3 негативними наслідками від деіндустріалізації, від недоінвестування, значної імпортозалежності, макрофінансової крихкості, безробіття, низького рівня доходів, значної соціальної нерівності тощо. Ситуація невизначеності ускладнюється війною та інституційною слабкістю держави. Додають гостроти проблемі економічної невизначеності пандемії, екологічні та техногенні катастрофи.

Від економічної невизначеності найбільше потерпають найуразливіші верстви населення - ті, що складають групу соціально ексклюзивних осіб. Водночас, саме 3 ними може бути пов'язане посилення цієї невизначеності. Тому економічна невизначеність та соціальна ексклюзія є взаємно пов'язаними явищами.

Власне термін «соціальна ексклюзія» виник та поширився в середині 1970-х років як реакція на неефективну соціальну політику уряду Франції. Неефективність проявлялася у тому, що окремі групи людей не були охоплені системою соціального захисту, поповнювали ряди люмпенів і не могли брати повноцінну участь у житті громадянського 
суспільства. До таких груп належали люди з обмеженими можливостями, особи пенсійного віку, багатодітні матері, колишні ув'язнені, ВІЛ-позитивні особи тощо. 3 цього часу соціальна ексклюзія розглядається як процес, y результаті якого людина/група людей повністю або частково виключаються з повноцінної участі в житті суспільства. При такому тлумаченні явища ексклюзії акцентується увага на нерівному доступі до економічних ресурсів та на нерівномірному розподілі благ у суспільстві. Визнається, що результатом цієї нерівності стає розшарування суспільства. Відповідно, зростають масштаби економічної невизначеності.

Ми формулюємо припущення, що однією з визначальних умов адекватної реакції на економічну невизначеність може ставати соціальна інклюзія (від англ. inclusion - «залучення», «включення», «охоплення чимось»).

Соціальна інклюзія $є$ відносно новою концепцією з теоретичним інструментарієм, який усе ще перебуває у процесі становлення. Тому термінологічному апарату іноді бракує чіткості та однозначності у тлумаченні змістів.

Упродовж чотирьох десятиліть концепція соціальної інклюзії розвивалася на грунті ідеї гарантування соціальних прав та досягнення вищого рівня добробуту. Наприкінці 1980-х років ця концепція була прийнята Європейським Союзом для формування соціальної політики [1]. У багатьох випадках вона замінила концепцію боротьби з бідністю, яка довгий час перебувала в центрі уваги урядів європейських країн. Розвиток цієї концепції відбувався, головним чином, як реакція на кризу держави загального добробуту в Європі, коли виявилася неспроможність ефективно вирішувати актуальні соціальні проблеми суспільства.

Якщо у розвинених країнах світу соціальна інклюзія вже стала реальною практикою, то в Україні лише відбувається осмислення ідеї та обговорення загальних підходів до ії практичної реалізації.

Ми виходимо з того, що соціальна інклюзія - це не просто протилежність (антипод) соціальної ексклюзії (відторгнення, відчуження), а свідоме формування певного стану суспільства. Ознакою цього стану $\epsilon$ те, що громадяни мають достатні, контрольовані й гарантовані суспільством умови в таких сферах, як:

- споживання благ на основі отримуваних доходів;

- володіння ресурсами та їх використання у процесі продуктивної зайнятості;

- управління через участь в інститутах громадянського суспільства та у прямому народовладді.

Визначальними у реалізації концепції соціальної інклюзії є такі фундаментальні ідеї:

- иінування, визнання і поваги до всіх членів суспільства, попри відмінності в освіті, у віці, в соціальному статусі тощо; 
- причетності та участі в різних сферах життя суспільства, за вільним вибором;

- матеріального добробуту, що передбачає матеріальну та фінансову підтримку вразливих верств;

- дотримання права людини на забезпечення гідного рівня життя.

Соціальна інклюзія є інтегральним явищем суспільного життя. Воно не обмежується лише вирішенням проблем найуразливіших верств суспільства. Виходячи за межі власне соціальної сфери, інклюзія «заходить» своїм змістом в економічну та політичну сфери.

Соціальна інклюзія $\epsilon$ необхідною умовою вирішення низки проблем, що передусім перебувають на межі економічного та соціального. Такою проблемою $\epsilon$, зокрема, працевлаштування вразливих груп населення, які не цікаві для успішного традиційного бізнесу. Адже таке працевлаштування передбачає додаткові витрати для пристосування робочого місця до особливих потреб людей з певними обмеженнями. У цьому та подібному випадках соціальна проблема могла б так $\mathrm{i}$ залишитися без вирішення через економічні обмеження. Тому виникає необхідність у нетрадиційних, більш соціально орієнтованих формах провадження підприємницької діяльності.

Ефективною формою поєднання економічного та соціального й, водночас, інструментом соціальної інклюзії стає особливий вид підприємництва. Його позначають спеціальним терміном - «соціальне підприємництво». Особливою ознакою соціального підприємництва стає інша ієрархія цінностей. Воно спрямоване не стільки на прибутковість бізнесу, скільки на досягнення суспільного добробуту.

Які соціальні проблеми, що стосуються соціальної інклюзії та розвитку соціальної сфери, вирішують соціальні підприємства?

Передусім соціальні підприємства сприяють вирішенню проблеми безробіття. Вони створюються для інтеграції на ринку праці безробітної, малокваліфікованої молоді, людей з інвалідністю тощо. При цьому зайнятість, як інклюзивний процес, не обмежується лише включенням найуразливіших верств населення й лише в ринок праці. Йдеться про створення нових можливостей споживання для осіб, що отримають вищі доходи. Стають доступними нові економічні блага, забезпечуються стандарти гідного життя. Нарешті, відбувається самореалізація у професії.

Зайнятість, завдяки соціальним підприємствам, сприяє інклюзії певних категорій населення у різні сфери суспільного життя. У соціальній сфері зайнятість виконує роль так званого «соціального ліфта». У економічній сфері працююча людина привласнює створений нею, а не перерозподілений державою на ії користь, дохід. У соціокультурній сфері формується потенціал вищого рівня освіти, особа стає частиною трудового колективу, розвиває комунікативні навички, отримує новий соціальний досвід тощо. 
Основні (концептуальні) лінії зв'язку між соціальною інклюзією, соціальним підприємництвом як іï формою, з одного боку, економічною невизначеністю - $з$ іншого, подано на рис. 1.

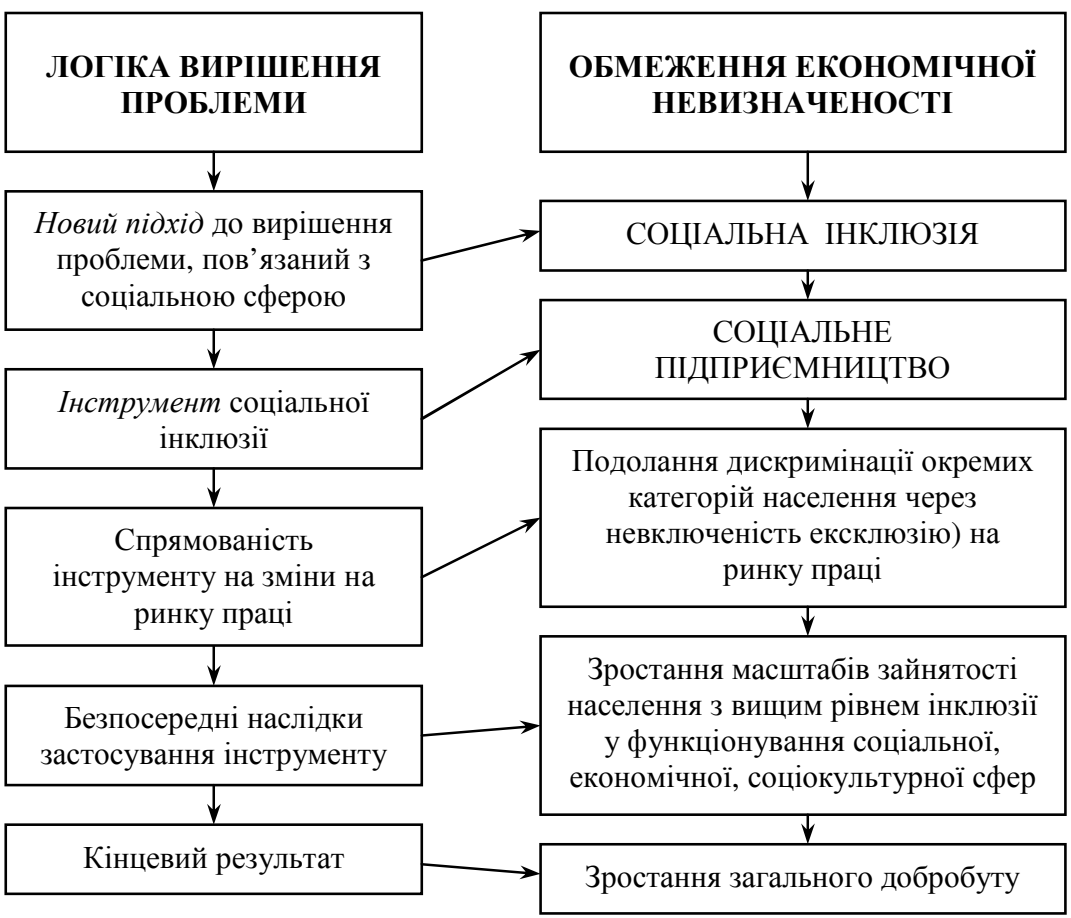

\section{Рис. 1. Взаємозв'язок економічної невизначеності, соціальної інклюзії та соціального підприємництва}

Джерело: складено авторами самостійно.

На рис. 1. ілюстрована ідея, що виключенням певних груп населення 3 трудової діяльності спричиняється вищий рівень невизначеності. Натомість, застосування інструментарію соціальної інклюзії, включно з соціальним підприємництвом, сприяє формуванню більшої економічної визначеності завдяки зайнятості. Остання втілюється у зростанні загального добробуту.

Ми розглядаємо категорію «соціальне підприсмництво» як елемент загальної теорії соціальної інклюзії. Тому уточнення змісту цього явища для нас має принципове значення.

Проблема соціальної інклюзії (ексклюзії) стала предметом наукових досліджень $з$ 1970-х рр. Натомість, соціальне підприємництво активно досліджується з 1990-х рр. 
Теоретичною основою соціального підприємництва вважається концепція так званої «змішаної цінності» Дж. Емерсона. Згідно з цією ідеєю, у будь-якій організації (включно з підприємством) відбувається поєднання економічної та соціальної сфер, які активно формують одна одну [2].

Виокремлюють чотири підходи до визначення природи (основного змісту) соціального підприємництва. Вони подані в аналітичній табл. 1. Таблиия 1

Підходи до визначення змісту соціального підприємництва

\begin{tabular}{|c|c|c|c|}
\hline $\begin{array}{c}\text { Ідентифікація } \\
\text { підходу }\end{array}$ & $\begin{array}{c}\text { Автори } \\
\text { (розробники) }\end{array}$ & $\begin{array}{c}\text { Основні ознаки } \\
\text { соціального } \\
\text { підприємництва }\end{array}$ & Обмеження підходу \\
\hline $\begin{array}{l}3 \text { позицій } \\
\text { широкого } \\
\text { тлумачення } \\
\text { змісту }\end{array}$ & $\begin{array}{l}\text { Дж. Віравардена, } \\
\text { Г. Морт, А. } \\
\text { Фоулер, Е. Шоу, } \\
\text { пов’язані } 3 \\
\text { діяльністю «Центру } \\
\text { з поліпшення } \\
\text { соціального } \\
\text { підприємництва» }\end{array}$ & $\begin{array}{l}\text { Охоплює діяльність широкого } \\
\text { кола організацій, а саме: } \\
\text { - державних соціальних } \\
\text { організацій; } \\
\text { - традиційних бізнес- } \\
\text { організацій, які завжди } \\
\text { мають соціальну складову; } \\
\text { - недержавних неприбуткових } \\
\text { організацій, спрямованих } \\
\text { на досягнення соціальних } \\
\text { цілей }\end{array}$ & $\begin{array}{l}\text { Не акцентуються } \\
\text { особливі ознаки } \\
\text { соціального } \\
\text { підприємництва, } \\
\text { воно ототожнюється } \\
\text { з будь-якою } \\
\text { діяльністю, яка має } \\
\text { соціальний ефект }\end{array}$ \\
\hline $\begin{array}{l}\text { Комбінований } \\
\text { (комерційно- } \\
\text { соціальний) } \\
\text { підхід }\end{array}$ & $\begin{array}{l}\text { А. Макміллан, } \\
\text { Дж. Робінсон, } \\
\text { Я. Рогалін }\end{array}$ & $\begin{array}{l}\text { Охоплює діяльність, яка } \\
\text { орієнтована на досягнення } \\
\text { не лише соціальних, але й } \\
\text { комерційних результатів }\end{array}$ & $\begin{array}{l}\text { Дає відповідь на } \\
\text { питання, у якому } \\
\text { поєднанні } \\
\text { відбувається } \\
\text { соціальна діяльність, } \\
\text { але не розкриває } \\
\text { власне зміст } \\
\text { соціального } \\
\text { підприємництва } \\
\end{array}$ \\
\hline $\begin{array}{l}\text { Інноваційний } \\
\text { підхід }\end{array}$ & $\begin{array}{l}\text { Дж.Вей-Скіллерн, } \\
\text { С. Вурро, Дж. Мейр, } \\
\text { Е. Нобоа, Е. Остін, } \\
\text { Ф. Перріні, } \\
\text { Х. Стівенсон }\end{array}$ & $\begin{array}{l}\text { Є частиною діяльності } \\
\text { інноваційних підприємств, } \\
\text { які зазвичай спрямовуються } \\
\text { на вирішення соціальних } \\
\text { проблем }\end{array}$ & $\begin{array}{l}\text { Не акцентується } \\
\text { можливість } \\
\text { досягнення } \\
\text { соціальних цілей } \\
\text { неінноваційними } \\
\text { підприємствами } \\
\end{array}$ \\
\hline $\begin{array}{l}\text { Проблемно- } \\
\text { орієнтований } \\
\text { підхід }\end{array}$ & $\begin{array}{l}\text { К. Лідбітер, } \\
\text { аналітики «Фонду } \\
\text { Шваба» }\end{array}$ & $\begin{array}{l}\text { Є діяльністю, соціальні } \\
\text { результати якої спрямовані } \\
\text { на певну соціальну групу - } \\
\text { людей з інвалідністю, } \\
\text { безхатченків тощо - або на } \\
\text { вирішення загальних } \\
\text { соціальних проблем, } \\
\text { пов'язаних з екологією, } \\
\text { енергетикою тощо }\end{array}$ & $\begin{array}{l}\text { Як різновид } \\
\text { широкого підходу, } \\
\text { не акцентує на } \\
\text { особливостях } \\
\text { соціального } \\
\text { підприємництва, } \\
\text { лише виокремлюючи } \\
\text { результат його } \\
\text { діяльності та } \\
\text { споживачів цих } \\
\text { результатів }\end{array}$ \\
\hline
\end{tabular}

Джерело: складено на основі джерела [3]. 
3 аналізу інформації, поданої в аналітичній табл. 1, випливає, що в науковому обігу використовуються переважно «широкі» тлумачення соціального підприємництва. Це - його тлумачення як діяльності без акцентування на особливостях та відмінностях такого підприємництва. Спільною рисою чотирьох розглянутих підходів $\epsilon$ визнання соціальної мети, яка, однак, тлумачиться по-різному.

На наш погляд, при визначенні соціального підприємництва, крім соціально визнаних результатів його діяльності, має відзначатися й інше. Йдеться про факт пріоритетності соціальних цілей над економічною метою максимізації прибутку та про спрямування прибутку на вирішення соціально важливих завдань громад чи суспільства. Отримання прибутку залишається метою соціального підприємництва саме як підприємництва. Але вона може мати для нього нижчі позиції в рейтингу цінностей, ніж соціальні цілі, включно з ціллю інклюзії. До того ж ознакою соціального підприємництва має бути переважання в управлінні демократичних засад над авторитарними. В іншому випадку, соціальні цілі можуть «відсуватися на вторинні позиції» через авторитарні методи управління.

Показово те, що фіксація того, що соціальне підприємство, як економічний суб'єкт, має орієнтуватися на отримання прибутку, відповідає документам офіційних органів ЄС. За цими документами [4; 5], соціальне підприємництво має відповідати таким критеріям:

- здійснювати реальну економічну діяльність;

- мати чітку соціальну мету, яка $є$ корисною для суспільства;

- отримувати прибуток, але мати обмеження на його розподіл та розподіл активів з метою забезпечення пріоритетності соціальної мети діяльності;

- бути незалежним від держави чи інших некомерційних організацій у проєктуванні своєї діяльності;

- забезпечувати інклюзивне (внутрішнє) управління та демократичні процедури прийняття рішень.

Важливо те, що згадані критерії сформульовані, усвідомлені та ними фактично почали керуватися творці українського соціального підприємництва [6].

У діяльності соціального підприємства виникає та постійно виявляється суперечність двох сторін діяльності - соціальної та економічної. 3 метою спрощення, ми використовуватимемо поняття економічна, підприємницька, комерційна сторона діяльності соціального підприємства як синоніми. Між соціальним та економічним у діяльності соціальних підприємств існує складна система взаємодії. Саме вона має ставати об'єктом дослідження при уточненні змісту поняття «соціальне підприємництво». Наші уявлення про особливості взаємодії двох сторін соціального підприємництва, які сформовані на основі вивчення досвіду 
соціального підприємництва інших країн та досвіду українських соціальних підприємств, подано на рис. 2.

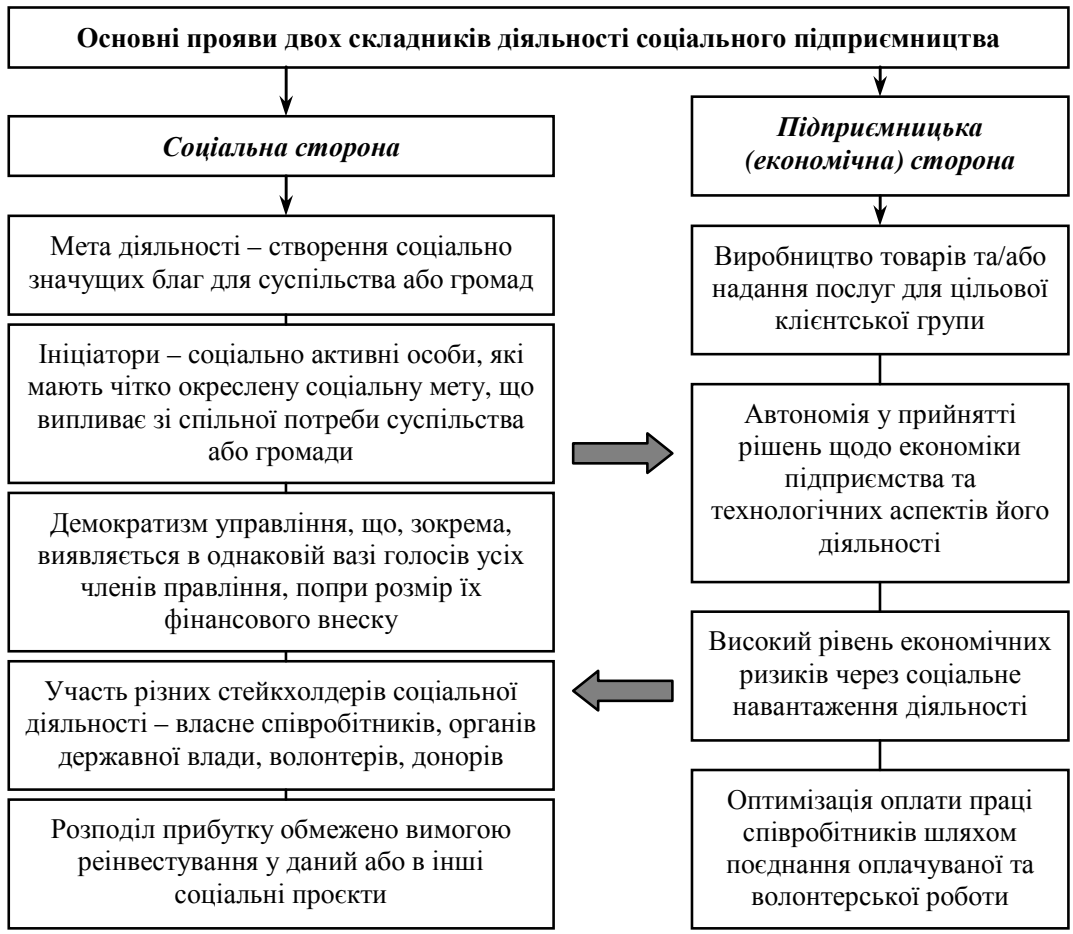

Рис. 2. Складники соціального підприємництва

Джерело: складено авторами самостійно.

На рис. 2 подано ті елементи соціального та економічного складників діяльності соціальних підприємств, зв'язок між якими пояснює об'єктивну суперечність соціального підприємництва. Вона (суперечність) виявляється у тому, що соціальна спрямованість, прагнення мінімізувати витрати 3 оплати праці заради збільшення реінвестованого прибутку тощо можуть спричиняти зменшення економічної ефективності. Це створює додаткові економічні ризики для підприємства саме як соціального. Певні ризики неефективної діяльності може породжувати й надмірна демократизація управлінського процесу.

Якщо соціальне підприємництво сприяє соціальній інклюзії, то принципово важливим для пояснення цього сприяння стає дослідження власне каналів впливу. На наш погляд, соціальне підприємництво визначає соціальну інклюзію через такі канали: 
- включення громадян у спільну діяльність, пов'язану з реалізацію соціальних проєктів;

спільну справу;

- формування персональної та групової відповідальності за

- розширення можливостей створення додаткових робочих місць та додаткової зайнятості;

- подолання соціальної ізольованості осіб 3 обмеженими можливостями;

- зміцнення громад шляхом активізації громадської діяльності членів цих громад;

- руйнування бар'єрів в уявленні громадян щодо престижної та непрестижної діяльності, відповідно, бар'єрів у взаєминах між громадянами;

- збільшення потенціалу вирішення соціальних проблем на рівні місцевих громад при зменшенні навантаження на місцеві бюджети;

- формування нових зразків та способів надання соціальних послуг у партнерських взаєминах бізнесу, місцевих громад та органів центральної державної влади.

Оскільки Україна не є лідером у соціальному підприємництві, то для української економіки та суспільства принципово важливим стає усвідомлення досвіду соціального підприємництва інших країн. Попри існування особливостей у кожній національній моделі соціального підприємництва, є підстави для виокремлення двох базових моделей. Щодо них можуть застосовуватися терміни «американська модель» та «європейська модель». Попри широке застосування цих термінів, показовим є те, що у багатьох країнах немає законодавчо закріпленого поняття «соціальне підприємництво». А уніфіковані підходи до ідентифікації соціальних підприємств у ЄС відсутні [7].

Інформація про особливості (відмінності) так званих американської та європейської моделей соціального підприємництва подана на рис. 3.

На рис. 3 подано ідею про те, що основна відмінність двох моделей соціального підприємництва пов'язана з акцентом на певному боці їх діяльності. В американській моделі більше акцентовано економічний (підприємницький, комерційний) бік діяльності. Натомість, у європейській моделі робиться більший акцент на соціальній спрямованості діяльності. Ці акценти віддзеркалені й у різному ставленні до оптимізації прибутку: значення прибутку в американській моделі соціального підприємництва $є$ більшим. Натомість, європейська модель є більш «патерналістською»: роль держави у ній помітніша. Американська модель соціального підприємництва сформувалася як реакція на згортання фінансування неприбуткових організацій у соціальній сфері. Більш ліберальний характер американської моделі виявляється, врешті-решт, у меншому рівні інклюзії. Натомість, європейська модель дає можливість забезпечувати вищий рівень соціальної інклюзії. 


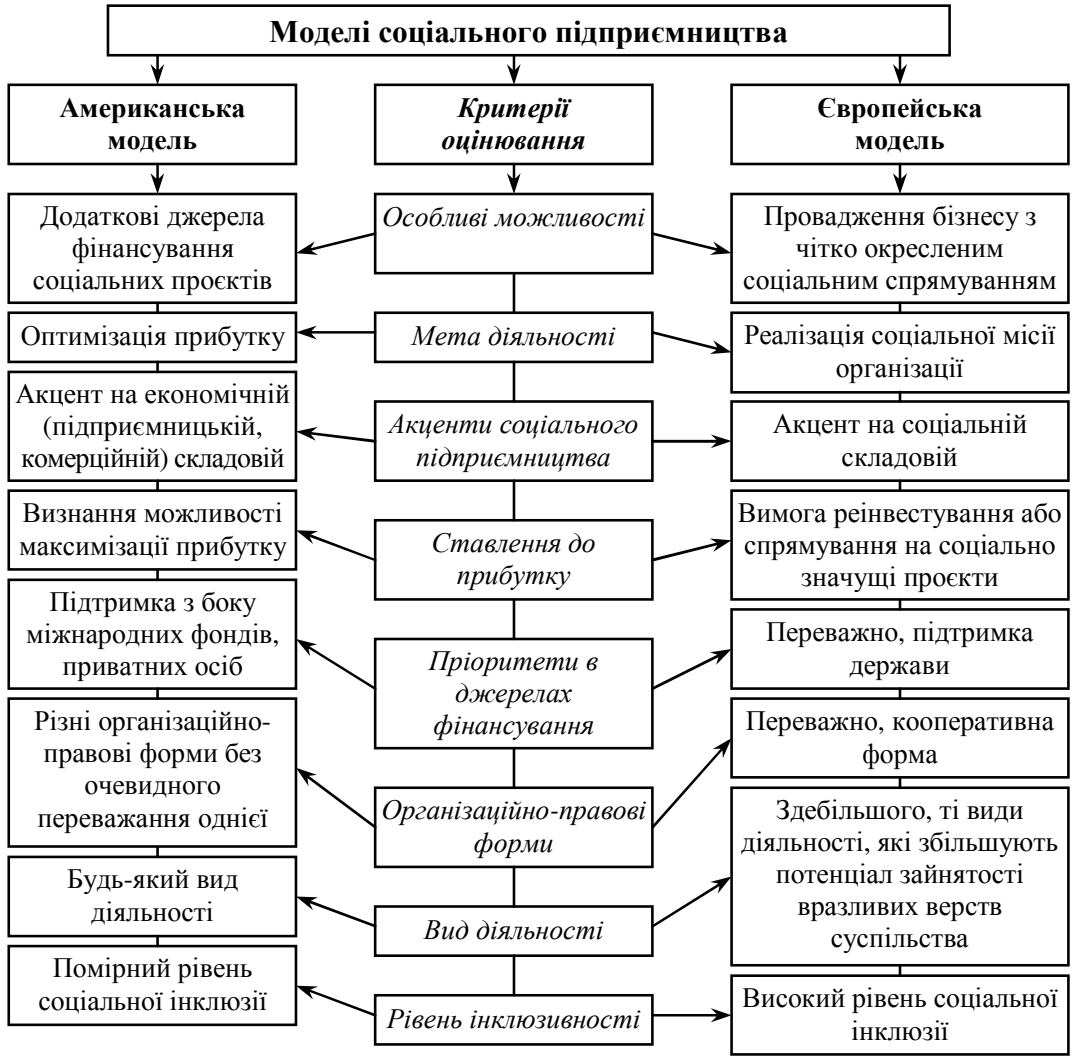

\section{Рис. 3. Ознаки двох базових моделей соціального підприємництва} Джерело: складено авьлоами на основі [8].

Є підстави для припущення, що власне назві «соціальне підприємництво» більше відповідають підприємства, організовані за логікою європейської моделі. Європейська модель соціального підприємництва - це «бізнес із соціальною місією» та 3 чітко акцентованим та підтримуваним соціальним ефектом діяльності. Досягнення цього ефекту стимулюється державою через законодавство, пільги та дотації.

Американській моделі могла би пасувати, до прикладу, назва «підприємництво, імплементоване в соціальну систему». В ній ідеться про різні способи сприяння підприємствам, що виконують соціальні функції. Це - фінансова, дослідницька, освітня підтримка міжнародних і приватних організацій, державні й федеральні програми реабілітації та працевлаштування осіб з особливими потребами, врахування факту задоволення цих потреб при наданні переваг та пільг підприємцям. 
На тлі двох базових моделей соціального підприємництва доцільно досліджувати та акцентувати особливості соціального підприємництва в окремих країнах. Це допомагатиме у відборі тих форм та інструментів впливу, які можуть сприяти формуванню української моделі соціального підприємництва. Спробуємо виокремити ті національні особливості, що виявляються в організаційних формах соціального підприємництва [9-11].

Типовою формою організації соціального підприємництва у більшості країн Європи є кооперативи. У Франції вони, до прикладу, називаються «кооперативами спільного інтересу», в Італії - «соціальними кооперативами». В Іспанії, Португалії, Франції, Греції, Хорватії соціальне підприємство може існувати виключно у формі соціальних кооперативів.

Соціальними підприємництвом у США вважається діяльність неприбуткових недержавних організацій, дохід яких використовується на статутні цілі організації, найчастіше, на вирішення соціальних проблем певних цільових груп громадян. У США достатньо, щоб товар або послуга сприяли вирішенню певної соціальної проблеми. I тоді підприємство, яке виробляє такий товар або надає таку послугу, вже може називатися соціальним.

У Великій Британії впроваджено спеціальний різновид соціального підприємництва - компанії, що працюють в інтересах громад. У країні діє понад 13 тисяч таких компаній. Велика Британія вважається європейським лідером. У країні діє близько 70 тис. соціальних підприємств, що забезпечують роботою майже мільйон британців. Їхній сумарний внесок в економіку становить понад 24 млрд фунтів стерлінгів. За підсумками 2017 р., 68\% соціальних підприємств підтримували людей 3 уразливих груп, 44\% - працевлаштовували таких людей, $28 \%$ - працювали в найбільш депресивних районах країни, формуючи економіку цих регіонів.

У Бельгії, Данії, Фінляндії, Люксембургу, Словенії статус соціального підприємства можуть отримати не лише кооперативи чи приватні компанії, а й громадські, волонтерські, благодійні організації та фонди.

У Латвії діє закон, за яким соціальні підприємства можуть існувати тільки у формі товариства 3 обмеженою відповідальністю (ТОВ). Їх соціальний статус має щороку підтверджувати відповідне міністерство. Держава звільняє соціальні підприємства від сплати податку на прибуток.

В Австрії, Бельгії, Іспанії, Італії, Нідерландах, Словенії, Фінляндії, Швеції поширена така форма соціальних підприємств, як «підприємства трудової інтеграції» (Work Integration Social Enterprise). Їх мета - це надання допомоги у працевлаштуванні та професійній підготовці незахищеним верствам громадян. 
Соціальне підприємництво не може існувати без державної підтримки. Для європейських країн - це не лише підтримка національних урядів, а й керівних органів СС. Ще у 2011 р. Європейська комісія схвалила довгострокову програму розвитку соціального підприємництва «ніціатива соціального підприємництва» (Social Entrepreneurship Initiative) [12]. Мета програми - стимулювати країни європейського регіону на розвиток сектору соціального підприємництва. Програма має три основні фокуси: популяризація діяльності соціальних підприємств, дружнє до соціальних підприємців законодавче середовище, створення умов для простішого отримання фінансування.

Європейська комісія виокремлює такі основні сфери соціального підприємництва:

- надання індивідуальних соціальних послуг у сфері охорони здоров'я, соціального захисту, освіти;

- догляд за дітьми, особами похилого віку, допомога малозабезпеченим;

- працевлаштування осіб, які опинилися у складних життєвих обставинах, та безробітних;

- місцевий розвиток депресивних/уразливих регіонів;

- переробка сміття, захист навколишнього середовища, спорт, мистецтво, культура, наука, дослідження та інновації, захист прав споживачів.

Перелік сфер соціального підприємництва у документах керівних органів ЄС важливий, окрім іншого, ще й тому, що віддзеркалює європейське тлумачення поняття «соціальне». Як свідчить перелік, цим поняттям охоплюються не лише явища, пов'язані з нерівністю людей у суспільстві. «Соціальне» тлумачиться також у зв'язку з процесами, які формують загальний рівень добробуту в країні. Це - не лише доходи й зайнятість, а й стан довкілля, культури, освіти, здоров'я громадян.

Реакція на створені умови та стимули для соціального підприємництва може аналізуватися за даними про кількість соціальних підприємств у окремих європейських країнах. Ця інформація подана на рис. 4.

Інформація з рис. 4 свідчить про різний потенціал соціального підприємництва у різних країнах. Це $є$ цілком природним, з огляду на відмінності у кількості та структурі населення країни, у рівні економічного розвитку. Однак, статистика соціальних підприємств засвідчує достатньо контроверсійний факт суттєвих (у рази) відмінностей між країнами 3 приблизно однаковим економічним потенціалом. Ідеться, зокрема, про трьох європейських лідерів - Францію, Німеччину та Велику Британію. Кількість підприємств у Німеччині у 2,7 рази є більшою, ніж у Франції, а у Великій Британії - у 1,7 разів більшою, ніж у Німеччини. Цей феномен потребує дослідження з метою з'ясування, що спричиняє відмінності: законодавство, державна підтримка чи особливості статистики соціальних підприємств. 


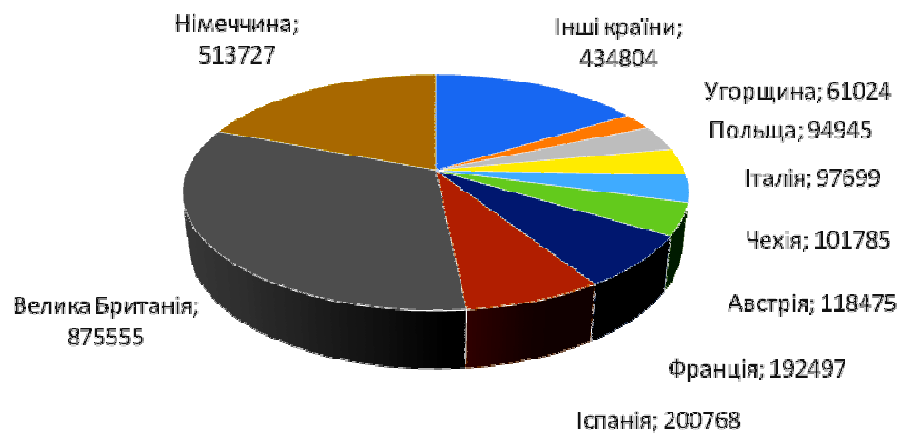

\section{Рис. 4. Кількість соціальних підприємств у країнах ЄС та Великій Британії, 2017 р.}

Джерело: складено на основі [13].

Українське соціальне підприємництво перебуває у зародковому стані, з огляду на зафіксовану кількість - 150 соціальних підприємств. У еволюції українського соціального підприємництва виокремлюють три етапи.

Периий етап (1991 - 2010 рр.) відзначився ініціативами міжнародних донорів, передусім USAID, які спонукали уряд та суспільство до розбудови системи соціального захисту. Насамперед ішлося про захист людей з певними обмеженнями та особливими потребами. Першим законодавчим актом, в якому присутня ідея інклюзії (хоча відсутній власне термін), став спеціальний Закон України №875-12 [14], прийнятий ще у 1991 році. Цей Закон є досі чинним та передбачає додаткові преференції для підприємницької діяльності з залученням людей 3 інвалідністю. Ним також передбачається діяльність спеціального фонду фінансування бізнес-ініціатив громадян України, що мають певні обмеження. У такий спосіб, завдяки Закону, створено певні умови для соціального підприємництва. Однак, підприємницька діяльність людей $з$ обмеженими можливостями не отримала назву «соціальне підприємництво».

Уперше термін «соціальне підприємництво» почав використовуватися в Україні лише в 2000-х рр. та дістав поширення завдяки «Мережі громадської дії в Україні» (UCAN). Мережа підтримувала діяльність 28-х українських соціальних підприємств, що існували в той час.

Другий етап (2010 - 2015 рр.) пов'язаний зі зростанням кількості досліджень про соціальне підприємництво, з розвитком відповідних програм та організаційних структур підтримки. Одним 3 перших, відзначених українською науковою спільнотою, стало дослідження українського автора К. Смаглій, яке побачило світ у 2014 р. [15]. У 2010 р. створено Консорціум «Сприяння розвитку соціального підприємництва в 
Україні». До нього увійшло 5 міжнародних організацій, що визначили за мету фінансову, освітню, консультативну допомогу соціальним підприємствам, які тільки-но розпочинали діяльність. Позитивним результатом діяльності Консорціуму стало те, що у декількох великих містах України соціальні підприємства почали активно діяти. А відповідальність за їх підтримку здебільшого почали брати на себе місцеві громади та місцевий бізнес.

На цьому етапі були створені такі організаційні форми підтримки українського соціального підприємництва, як Всеукраїнський ресурсний центр розвитку соціального підприємництва «Соціальні ініціативи», портал socialbusiness.in.ua з першим реєстром соціальних підприємств, програма соціального інвестування для соціальних підприємств 3 відносно невисокими процентами за кредит.

Tpemiŭ eman (початок 2016 р. й дотепер) характеризується зростанням кількості соціальних підприємств, розширенням кола суб'єктів, які підтримують соціальне підприємництво. Зокрема, на цьому етапі активно долучилися український малий та середній бізнес, українські університети. Значну роль продовжують відігравати міжнародні організації. На цьому етапі відбулися зміни акцентів у діяльності соціальних підприємств. Сучасне українське соціальне підприємництво та волонтерський рух долають наслідки російсько-української війни на Сході України. Предметом уваги стають біженці, діти прифронтових територій, воїни, які потребують реабілітації після поранень, родини загиблих тощо.

Саме на третьому етапі в українських університетах почали викладатися навчальні курси з соціального підприємництва. Відповідно, почали готуватися професіонали з необхідними компетентностями.

3 огляду на значну фінансову та консультативну підтримку соціального підприємництва 3 країн $Є С$, можна було б сподіватися тиражування в Україні європейської моделі. За критерієм пріоритетності соціального над економічним, європейська модель в Україні, дійсно, частково реалізується. Але українській національній моделі бракує другої частини європейської моделі, а саме: послідовної економічної державної підтримки. У цій другій частині українська модель соціального підприємництва більше нагадує американську 3 iї ініціативними приватними фондами та громадянами.

Виглядає так, що відбувається створення української національної моделі соціального підприємництва з особливими ознаками. В їі межах соціальні підприємці вимушено перебирають на себе ті соціальні функції, які не виконує держава, хоча мала би виконувати за законодавством. Причинами невиконання державою належних їй соціальних функцій в українській дійсності стають: слабкість інститутів державної влади, брак політичної волі, сформована олігархічна модель економіки 3 несоціальними цінностями тощо. 


\section{Висновки:}

За результатами аналізу зв'язку між соціальною інклюзією та соціальним підприємництвом, 3 одного боку, та економічною невизначеністю - з іншого, можемо зробити такі узагальнення.

Соціальне підприємництво як форма соціальної інклюзії, незаперечно, розширює масштаби економічної визначеності. Адже через соціальні підприємства досягається більше охоплення громадян трудовою діяльністю, отримання ними зароблених (факторних), а не перерозподілених доходів, забезпечується розвиток професійних та комунікативних навичок, активізується участь в управлінні та в інститутах влади.

Одночасно, соціальне підприємництво має певний потенціал розширення економічної невизначеності. Він пов'язаний з суперечністю між соціальним та економічним боком діяльності, яка [суперечність] виявляється у тому, що прерогатива соціального може породжувати втрату економічної ефективності.

Суперечність між соціальним та економічним у діяльності соціальних підприємств вирішується в межах конкретної національної моделі соціального підприємництва. Ця модель означає існування особливих вимог держави до організаційних форм соціального підприємництва, а також особливих інструментів державної підтримки та форм взаємодії з інститутами громадянського суспільства, 3 міжнародними організаціями, з місцевими громадами та несоціальним бізнесом.

Імовірно, що в Україні формується змішана модель соціального підприємництва, яка вимушено поєднує певні ознаки так званих європейської та американської моделей. Ця змішаність значною мірою визначається лакунами (провалами) діяльності сучасної української держави у виконанні соціальних функцій, відповідно, в забезпеченні соціальних гарантій та стандартів.

\section{Jimepamypa:}

1. Monitoring social inclusion in Europe edited by Anthony B. Atkinson, Anne-Catherine Guio and Eric Marlier. 2017. URL : https://scholar.google.com.ua/citations?user=QgmO3FAAAAAJ\&hl=uk\&oi=sra.

2. Emerson J. The blended value map: Tracking the Intersects and Opportunities of Economic, Social and Environmental Value Creation. 2003. URL : https://community-wealth.org/content/blended-value-maptracking-intersects-and-opportunities-economic-social-and-environmental.

3. Соціальне підприємництво: від ідеї до суспільних змін : посібник / А. Свинчук, А. Корнецький, М. Гончарова, В. Назарук, Н. Гусак, А. Туманова. Київ : ТОВ «ПІДПРИЄМСТВО «ВІ ЕН ЕЙ», 2017. 188 с. 
4. Social Enterprise in Europe Developing Legal Systems which Support Social Enterprise Growth. URL : http://www.bwbllp.com/knowledge/ 2015/10/21/ocial-enterprise-in-europe-developing-legal-systems-which-supportsocial-enterprise-growth/.

5. Defourny J., Nyssens M. Social Enterprise in Europe: Recent Trends and Developments. 2008. URL : http://www.emes.net/site/wp-content/ uploads/WP_08_01_SE_WEB.pdf.

6. Зелена книга соціального підприємництва в Україні, Український форум благодійників, Інститут інклюзивного розвитку. Київ, 2019.

7. European Commission A map of social enterprises and their ecosystems in Europe. Synthesis Report. 2014. URL : https://www.age-platform. eu/publications/map-social-enterprises-and-their-eco-systems-europe.

8. Школяр М. В. Соціальне підприємництво як інструмент вирішення соціальних проблем. Науковий вісник НЛТУ Украӥни. Серія економічна. 2017. Вип. 27. №2. С. 85-89.

9. Duniam M., Eversole R. Social Enterprises and Local Government: A Scoping Study. Australian Centre of Excellence for Local Government. 2013. $23 \mathrm{p}$.

10. The European Social Enterprise Law Association. URL : http://www.socialenterprisebsr.net/2015/12/the-european-social-enterpriselaw-association/.

11. Social enterprise: market trends. 2017. URL : https://www.gov.uk/ government/publications/social-enterprise-market-trends-2017. The European Social Enterprise Law Association. URL : http://www.socialenterprisebsr. net/2015/12/the-european-social-enterprise-law-association/.

12. Social Entrepreneurship Initiative. URL : http://ec.europa.eu/ growth/sectors/social-economy/enterprises/index_en.htm.

13. Social enterprise: market trends 2017. URL : https://www.gov. uk/government/publications/social-enterprise-market-trends-2017.

14. Про основи соціальної захищеності осіб з інвалідністю в Україні : Закон України №876-12 від 21.03.1991 p. URL : https://zakon. rada.gov.ua/laws/show/875-12\#Text.

15. Смаглій К. Зміни творить кожен із нас: соціальне підприємництво та стратегічна філантропія. Київ : Видавничий дім «Києво-Могилянська академія», 2014. 


\title{
ІНФРАСТРУКТУРА РИНКУ НЕРУХОМОСТІ ЯК ЧИННИК ЕКОНОМІЧНОЇ ВИЗНАЧЕНОСТІ ТА СТАБІЛЬНОСТІ РИНКУ
}

\author{
Топал Анатолій Анатолійович, \\ керівник Громадської організачіi \\ «Асочіація професійних управляючих нерухомістю», \\ стариий викладач кафедри теоретичної та прикладної економіки \\ ВНЗ «Університет економіки та права «КРОК», \\ ORCID: https://orcid.org/0000-0003-2624-4540,
}

\begin{abstract}
Піта Юрій Аанатолійович, президент «Асоиіації фахівиів з нерухомого майна (рієлторів) Украӥни», старший викладач кафедри теоретичної та прикладної економіки, ВНЗ «Університет економіки та права «КРОК», ORCID: https://orcid.org/0000-0002-2010-8735
\end{abstract}

Анотація. Сучасний ринок нерухомого майна в Україні міг би ефективно виконувати роль стабілізатора національної економіки у кризових умовах. Саме ринок нерухомого майна називають «локомотивом економіки». Макроекономічний вплив ринку нерухомого майна на загальний стан економіки є суттєвим для всіх економічно розвинутих країн. Український ринок нерухомості, ймовірно, не мав би бути винятком. Стабілізаційна функція цього ринку зростає в умовах економічних криз принаймні з двох причин. По-перше, економічні суб'єкти сприймають нерухоме майно як найбільш надійний актив порівняно, наприклад, 3 різними видами фінансових активів. По-друге, саме ринок нерухомого майна стає «потужним магнітом» для інвестицій. Це має забезпечувати зростання кількості робочих місць та розвиток пов'язаних з ринком нерухомого майна галузей. У цьому розділі досліджується проблема вдосконалення інфраструктури ринку й окремих видів підприємницької діяльності для забезпечення його стабільності й органічної взаємодії 3 іншими галузевими ринками.

Ключові слова: ринок нерухомості, підприємництво на ринку нерухомості, рієлторство, оціночна діяльність, управління нерухомістю, дивелоперська діяльність.

Актуальність дослідження національного ринку нерухомості 3 позицій удосконалення підприємницької інфраструктури цього ринку не викликає жодних сумнівів. Адже цей ринок на всіх етапах новітньої української економічної історії забезпечував створення відносно великої частки ВВП країни та сотні тисяч робочих місць. Інформація про частку ринку нерухомості у створеному ВВП країни подана на рис. 1. 


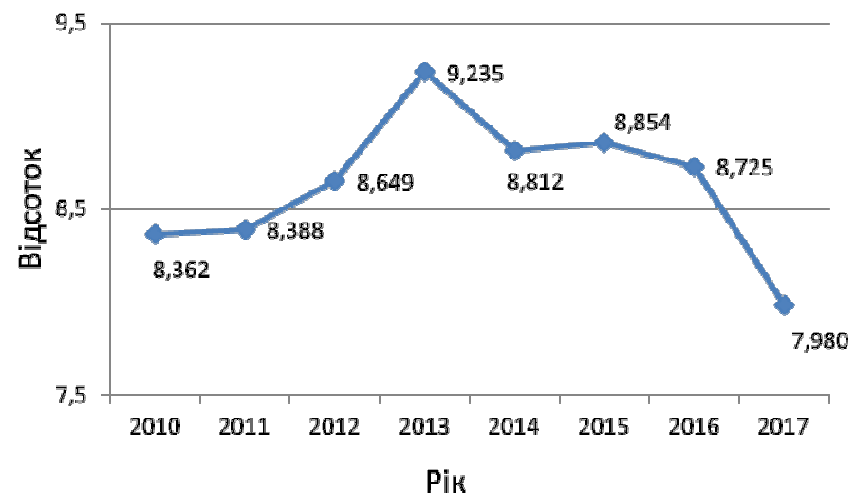

Рис. 1. Динаміка частки «Операцій з нерухомим майном» у створенні ВВП України

Джерело: створено авторами на основі [1].

Інформація, подана на рис. 1, свідчить про те, що частка діяльності, означеної як «Операції з нерухомим майном» у ВВП країни, є значною. Вона $є$ співставною, наприклад, з частками таких сфер, як освіта, медицина тощо. Завдяки ринку нерухомого майна зазвичай створювалася значна кількість робочих місць в українській економіці. Динаміка кількості робочих місць, що забезпечувалися завдяки функціонуванню ринку нерухомості, ілюстрована на рис. 2.

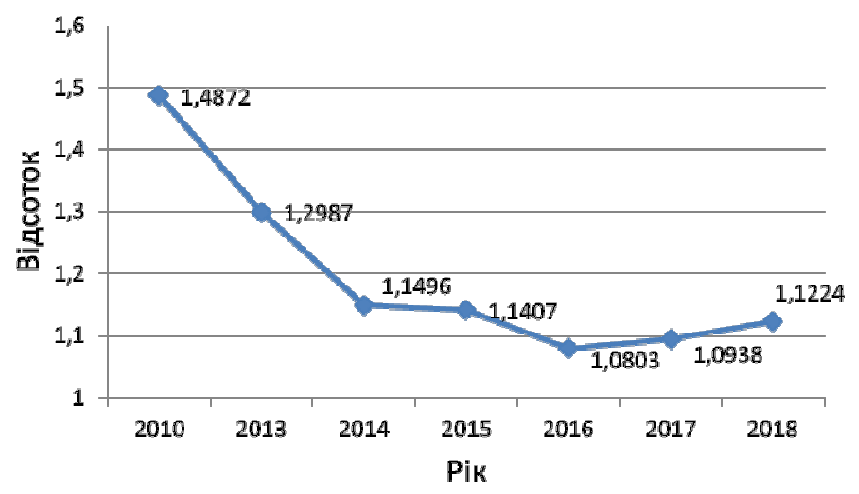

Рис.2. Динаміка частки зайнятих осіб у сфері

«Операції 3 нерухомим майном» в Україні у 2010 - 2018 рp.

Джерело: створено авторами на основі [1].

Інформація про частку зайнятих у сфері «Операції з нерухомим майном» на рис. 2 свідчить про те, що, починаючи з 2016 року, 
почалася позитивна динаміка зростання частки зайнятих осіб. Вона впритул наблизилася до рівня 2014 року, коли розпочався спад у зв'язку з російсько-українською війною.

Проблеми організації та функціонування ринку нерухомого майна $є$ предметом багатьох досліджень фахівців та експертів цього ринку [2-4]. Більшість сучасних досліджень ринку нерухомості присвячені з'ясуванню трендів зміни цін на нерухомість та оцінюванню чинників, які впливають на динаміку цін. Але $\epsilon$ й багато досліджень, присвячених більш фундаментальним питанням, а саме: зв'язку між загальною економічною кризою та станом ринку нерухомості, способам подолання наслідків кризи з використанням ринку нерухомості.

Вітчизняні дослідники ринку нерухомості [5-7] зосереджують свою увагу не лише на тенденціях зміни цін на нерухомість, а й на осмисленні ролі цього ринку в стабілізації національної економіки. Зокрема, досліджується зв'язок між розвитком ринку нерухомості, 3 одного боку, та розвитком фінансового ринку - з іншого, між динамікою реальних доходів українців та масштабами придбання житлової, комерційної тощо нерухомості.

І вітчизняних, й іноземних дослідників з 2020 р. цікавить оцінювання та прогнозування впливу на еволюцію ринку нерухомості надзвичайної ситуації - пандемії Covid-19 [8].

Сучасний ринок нерухомого майна України формується представниками кількох видів підприємницької діяльності та передбачає їх взаємодію. Необхідність такого об'єднання зумовлюється складністю самої сфери економіки нерухомості, урізноманітненням структури попиту на нерухоме майно та зростаючими потребами споживачів. 3 огляду на все зазначене, ми робимо припущення про доцільність застосування в аналізі ринку та власне в практичній діяльності терміну «інфраструктура ринку нерухомості».

Як і будь-яка інфраструктура інших ринків, інфраструктура ринку нерухомості має охоплювати окремі сегменти ринку, репрезентовані підприємцями 3 різними компетентностями. Попри відмінність компетентностей, всі вони пов'язані зі створенням послуг, якими супроводжується купівля-продаж, відтворення та використання нерухомого майна. Наше уявлення про інфраструктуру ринку нерухомості ілюстровано схемою (рис. 3).

На рис. 3 ілюстровано такі ідеї щодо інфраструктури ринку нерухомості загалом та підприємництва на ринку нерухомості зокрема:

- інфраструктура ринку нерухомості охоплює так зване «ядро», що складається з підприємців пов' язаних між собою видів діяльності, а саме: рієлтерів, оцінщиків майна, управляючих майном, девелоперів;

- окрім «ядра», функціонує елемент інфраструктури у вигляді так званого «захисного поля» у складі п'ятьох елементів, а саме: національних 
регуляторів (органів державної влади), банків, пов'язаних з іпотечним кредитуванням, будівельних (ремонтних) організацій, страховиків у сфері нерухомості та консалтингових компаній;

- об’єднані ринком нерухомого майна, підприємства, що формують «ядро» інфраструктури ринку, виконують хоча й пов’язані, але особливі функції. Тому йдеться про чотири сегменти «ядра», а саме: рієлторів, оцінщиків, управляючих нерухомістю та девелоперів;

- «захисний пояс» інфраструктури ринку нерухомості покликаний формувати його стабілізуюче - ефективне та безпечне - середовище, пов'язане з законодавством (правилами діяльності), формуванням джерел для інвестування, відтворенням об'єктів нерухомості, страхуванням та інтелектуальним - аналіз та обгрунтування рішень - забезпеченням.

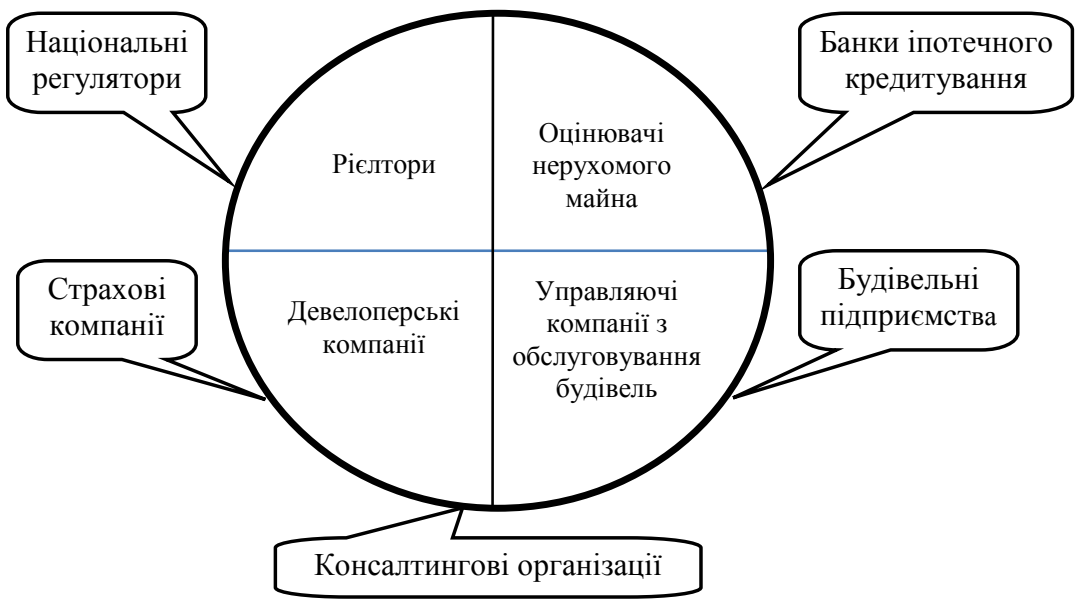

Рис. 3. Інфраструктура ринку нерухомості та відповідні форми підприсмницької діяльності

Джерело: створено авторами самостійно.

Підприємництво в кожному з сегментів «ядра» інфраструктури ринку нерухомості - в рієлторстві, оцінці, управлінні будівель, девелоперстві - має в Україні власні організаційні, правові особливості та певні проблеми. Спробуємо охарактеризувати найбільш визначальні особливості та актуальні проблеми кожного з них.

Осердя підприємницької діяльності на українському ринку нерухомості формує рієлторство. Воно вже виокремилося як специфічний функціональний напрямок та як вид діяльності.

У суб’єктів підприємницької рієлторської діяльності формуються особливі стосунки з національними регуляторами. Ці стосунки є достатньо контроверсійними. Зокрема, існує невідповідність між офіційним 
тлумаченням змісту поняття «рієлторська діяльність» та сутністю цієї діяльності з позицій операторів ринку нерухомості.

За Класифікатором видів економічної діяльності [9] (секція I), виокремлено діяльність таких економічних суб' єктів: «орендодавців, агентів i/aбо посередників 3 продажу або купівлі, надання в оренду нерухомого майна, надання інших послуг відносно нерухомого майна, таких як оцінювання об'єктів нерухомості або дії в якості агентів рахунків депонування». У документі зазначено, що ця діяльність «може здійснюватися відносно власної або орендованої нерухомості та може виконуватися на основі фіксованих виплат або на основі контракту». Йдеться також про діяльність з будівництва конструкцій у поєднанні 3 набуттям прав власності або оренди цих конструкцій. Важливо також те, що в документі виокремлюється діяльність «менеджерів 3 управління нерухомим майном». Предмет діяльності останніх - це три групи операції 3 нерухомим майном, що охоплюють:

- купівлю та продаж власного нерухомого майна;

- надання в оренду;

- надання в експлуатацію власного чи орендованого нерухомого майна.

В аналізованому документі йдеться про таку форму підприємництва, як агентства нерухомості, які, за уявленнями творців цього документа, охоплюють таку діяльність:

- посередницькі послуги з купівлі, продажу або надання в оренду нерухомого майна на підставі фіксованих виплат або на контрактній основі;

- надання за винагороду або на основі контракту консультаційних послуг і послуг з оцінювання нерухомого майна, які пов'язані з його купівлею, продажем або наданням в оренду;

- послуги агентів умовного депонування.

Саме таке тлумачення діяльності рієлторів призводить до конфлікту між суміжними професіями - рієлторами, агентами 3 нерухомості, оцінювачами та управителями нерухомого майна.

Намагання прийняти закони [10] без узгодження інтересів та без необхідної комунікації з професійною спільнотою рієлторів, замість стабілізації та визначеності, породжує дестабілізацію та невизначеність.

Значна частина угод з нерухомим майном відбувається з залученням рієлторів або агентів з нерухомості. Так, за даними Асоціації професійних управляючих нерухомістю, спостерігалася така динаміка кількості угод за участі професійних рієлторів (у \% до загальної кількості угод на ринку нерухомості):

$$
\begin{aligned}
& 2001 \text { - } 2008 \text { pp. }-75-80 \% \text {; } \\
& 2009 \text { p. - 60-65\%; } \\
& 2010 \text { p. - близько 50\%; } \\
& 2011 \text { p. - 40\%; }
\end{aligned}
$$


2012 р. - близько $37 \%$ [11];

$2013-2018$ pp. $-60-65 \%$ [12].

Аналіз динаміки угод 3 нерухомістю, за участі професійних рієлторів, засвідчує коливальний характер змін. До певної межі прослідковується тенденція скорочення цієї частки. Зазвичай це відбувається в періоди економічних рецесій та збільшення недовіри до органів публічної влади. І навпаки, частка таких угод зростає в періоди більшої економічної стабільності та довіри до дій влади.

Важливим аспектом організації підприємницької діяльності на ринку нерухомості є ставлення споживачів рієлторських послуг до компетентності професіоналів ринку нерухомості й очікування споживачів щодо результатів діяльності. 3 опитувань споживачів виявилося таке: iз $100 \%$ потенційних покупців та продавців нерухомості тільки $11 \%$ категорично відмовляються від співпраці з рієлторами, $15 \%$ вже визначилися, з яким рієлтором будуть працювати, 16\% мають бажання працювати з рієлтором, але не знають, до кого звернутися [12].

Ставлення клієнтів до рієлторства є достатньо контроверсійним. Адже 31\% клієнтів фактично готові працювати 3 рієлтором, але не розуміють суті рієлторської послуги та не знають ії вартості. А 23\% клієнтів готові працювати з рієлтором, але остерігаються низької якості рієлторської послуги. Лише 4\% споживачів мають сумнів щодо необхідності використання рієлторської послуги [13]. Аналітики ринку нерухомості фіксують значний дефіцит таких послуг 3 ознаками високої якості, прозорості та зрозумілості для споживача змісту діяльності рієлтора.

3 аналізу статистики опитувань споживачів на ринку нерухомості випливає висновок про брак довіри у відносинах між фахівцями ринку та клієнтами, необізнаність клієнтів у перевагах співпраці з фахівцями ринку та недостатність фахівців найвищої кваліфікації.

Рієлторська діяльність, як окремий вид підприємництва, має об'єктивні економічні та соціальні підстави для майбутнього розвитку. Де-факто, сформувався окремий субринок послуг - ринок рієлторської послуги. Де-юре, ще триває легалізація цього ринку. Чинна законодавча база для функціонування українського ринку рієлторських послуг охоплює такі кодекси: Цивільний кодекс України, Господарський кодекс України, Податковий кодекс України. Ї̈̈ складниками є окремі закони, а саме: Закон України «Про запобігання та протидію легалізації (відмиванню) доходів, одержаних злочинним шляхом, фінансуванню тероризму та фінансуванню розповсюдження зброї масового знищення», Закон України «Про захист прав споживачів», Закон України «Про рекламу». Важливим складником законодавчої бази $є$ й Наказ ДП «УкрНДНЦ» Національного органу стандартизації №40 від 27 лютого 2019 р. «Про прийняття національного стандарту ДСТЕУ ЕN 15733:2019 
«Послуги агентів 3 нерухомості. Вимоги до надання послуг агентів 3 нерухомості» [14].

На жаль, спеціального закону про регулювання реєлторської діяльності в Україні не існує. Вже багато років точиться дискусія між прихильниками прийняття такого закону та прихильниками ідеї непотрібності такого спеціального законодавчого регулювання. Обидві сторони дискусії мають аргументи на обгрунтування власного підходу.

Основна проблема регулювання ринку нерухомості полягає у відсутності визначеності саме в механізмах регулювання. Йдеться про вибір між двома альтернативами, а саме: між «жорстким» державним регулюванням та «м'яким» регулюванням 3 передачею повноважень організаціям саморегулювання. На нашу думку, на початковому етапі упорядкування діяльності ринку рієлторських послуг має існувати «змішане регулювання» держави та громадських (самоврядних) професійних організацій. Критерієм такого поєднання має стати сприяння визначеності на ринку та його розвитку. В подальшому має реалізуватися вектор у бік більшого саморегулювання ринку.

За даними, зібраними органами державної статистики, за участі громадських об'єднань рієлторів та експертів ринку, кількість учасників ринку рієлторської послуги коливається віл 50 до 65 тис. осіб [1]. Більш точну оцінку кількості учасників ринку для забезпечення вищого рівня визначеності операцій надати неможливо з кількох причин:

- існує значна кількість підприємств у вигляді так званих ФОПів, які вже припинили або припиняють свою діяльність, але це ще не відбулося офіційно;

- значна кількість підприємців не легалізує своєї діяльності;

- не існує єдиного реєстру учасників ринку рієлторських послуг.

Законодавче визнання рієлторських послуг, як окремого продукту піприємницької діяльності, залишається незавершеним. Це формує одну з основних причин економічної невизначеності на цьому ринку. Саме так вважає український дослідник Міненко М. А. Він, зокрема, фіксує такі конкретні причини невизначеності ринку, як часткове відсторонення держави від вирішення питання легітимізації рієлторства як послуги, відсутність Закону України «Про рієлторську (брокерську) діяльність», що сприяв би формуванню прозорого правового поля [15].

Важлива роль у функціонуванні достатньо «молодого» українського ринку нерухомості, що перебуває в стані високої невизначеності, належить громадським об'єднанням професіоналів ринку. Об'єднання лобіюють, організовують, виступають із законодавчими ініціативами, намагаються робити діяльність прозорою, захищають інтереси учасників ринку. Такими, зокрема, є Асоціація фахівців 3 нерухомого майна (рієлторів) України, Спілка фахівців з нерухомого майна України, Рієлторська палата України, Гільдія рієлторів України. Але демократичні 
принципи функціонування громадських об'єднань іноді заважають формуванню спільного бачення проблем, а також розробці однакових підходів до організації відносин з органами державної влади тощо. Це може ставати причиною уповільненого формування правового поля та правового визнання рієлторства як офіційно-стандартизованої професії.

На початку 2020-х рр. на заваді розвитку рієлторства, як професії та різновиду підприємницької діяльності, постають невирішені проблеми системних зловживань з боку представників влади. Йдеться, зокрема, й про представників депутатського корпусу та окремих чиновників, що намагаються «зарегулювати» ринок 3 метою створення різних «схем збирання коштів» 3 усіх учасників ринку. Правова невизначеність стає однією з головних причин низького рівня довіри споживача послуг до фахівців ринку нерухомості. Адже значною мірою через дії влади рієлтор, як дійова особа ринку, ще не має зрозумілого для споживача послуг загальнодержавного професійно-правового статусу.

Рієлторська спільнота України здобуває свій статус та довіру українських громадян в умовах економічної невизначеності різними шляхами. Важливими здобутками професійної спільноти є такі дії й такі результати цих дій:

- постійна участь у міжнародних конгресах Національної Асоціації Рієлторів США, Міжнародної федерації з нерухомості (FIABCI), Міжнародної асоціації менеджменту нерухомості;

- постійне представництво фахових об'єднань у роботі освітніх програм Свропейського Фонду освіти;

- упровадження на рівні Державного Стандарту України європейської норми (EN) Стандарту «Послуги агентів 3 нерухомості. Вимоги до надання послуг агентів з нерухомості»;

- участь у робочих групах 3 розробки проєкту Закону про врегулювання рієлторської (брокерської) діяльності;

- участь у роботі Міжгалузевої Кваліфікаційної Ради з розробки професійних стандартів у сфері менеджменту нерухомості, благоустрою та житлово-комунального господарства (ЖКГ) щодо розробки професійних стандартів «Рієлтор» та «Агент з нерухомості»;

- участь у створенні магістерських програм, у межах яких реалізується спеціалізація, що можна визначити як «фахівець ринку нерухомого майна»;

- участь у формуванні загальної системи освітньо-професійної підготовки спеціалістів ринку рієлторської послуги за єдиним державним стандартом.

Першочерговими для остаточної легітимізації рієлторства як окремої професії та виду підприємницької діяльності, на наш погляд, мають бути такі кроки:

- створення єдиного національного керівного органу на засадах саморегулювання, до функцій якого належатиме таке: представництво 
інтересів учасників ринку у взаєминах 3 державними інституціями та іншими зацікавленими суб' єктами відносин, формування реєстру офіційних рієлторів України, участь в атестації та сертифікації професіоналів ринку, розробка стандартів якості наданих послуг та організація заходів з реагування професійної спільноти на їх порушення;

- затвердження єдиних стандартизованих підходів до рієлторської діяльності як особливого виду підприємництва;

- подальше впровадження ДСТУ в частині «Послуги агентів 3 нерухомості. Вимоги до надання послуг агентів 3 нерухомості»;

- розробка Професійного Стандарту «Рієлтор» та «Агент 3 нерухомості» й затвердження на його основі освітньо-професійних програм підготовки бакалаврів та магістрів за відповідним фахом;

- імплементація до Державного класифікатора професій і Довідника кваліфікаційних характеристик професій необхідної та узгодженої інформації щодо спеціальності «Рієлтор» та «Агент з нерухомості»;

- створення системи підтвердження кваліфікацій «Рієлтор» та «Агент з нерухомості» за міжнародними вимогами.

Підприємництво в оціночній діяльності України характеризується низкою організаційних особливостей та невирішених проблем.

Оцінювачем в Україні може бути фізична особа (громадянин України, іноземець або особа без громадянства), яка має базову або повну вищу освіту. Згадана особа має пройти навчання у навчальному закладі, який уклав відповідну угоду про навчання оцінювачів з Фондом державного майна України.

Визнання необхідності спеціальної вищої освіти для оцінювачів $€$ значною перевагою та здобутком у цій сфері діяльності. Крім іншого, фахівець з оцінювання майна повинен здійснити стажування протягом одного року в складі організації, що займається оціночною діяльністю, за відповідними вузькими спеціалізаціями, скласти кваліфікаційний іспит та отримати кваліфікаційне свідоцтво оцінювача відповідно до вимог законодавства України [16].

Позитивом в організації оціночної діяльності $є$ також існування вимог і порядку включення інформації про оцінювачів та суб'єктів оціночної діяльності до Державного реєстру. Законодавство визначає й правові засади та процедури збирання, нагромадження, обробки й отримання інформації щодо оціночної діяльності. Згідно зі згаданим Державним реєстром на червень 2020 р. в Україні офіційно зареєстровано 13125 осіб.

Професійні оцінювачі об'єднані у громадську організацію «Всеукраїнська Асоціація Фахівців Оцінки», яка виконує функцію представництва інтересів підприємців-оцінювачів. Ця організація забезпечує ідентифікацію й оприлюднення проблем, які обмежують та 
гальмують оціночну діяльність. Зрозуміло, що тривале ігнорування цих проблем спричиняє зростання невизначеності в оціночній сфері.

До проблем в організації оціночної діяльності, консервація яких збільшує невизначеність у цій сфері, належить таке:

- відсутність новітньої державної політики в галузі оціночної діяльності з чітко окресленими новими вимогами до професії оцінювачів та до оціночної діяльності загалом;

- брак правових основ поєднання державного регулювання та саморегулювання оціночної діяльності, а також делегування окремих функцій держави професійним саморегульованим організаціям;

- складність для розуміння, тлумачення і застосування чинного Закону України «Про оцінку майна, майнових прав та професійну оціночну діяльність в Україні». Йдеться передусім про права й обов'язки держави, оціночної спільноти, громадськості та кінцевих споживачів оціночних послуг. А також про права та обов'язки щодо ціноутворення й ініціатив регулювання діяльності.

Громадська організація «Всеукраїнська Асоціація Фахівців Оцінки» усвідомлює необхідність створення Концепції розвитку оціночної діяльності у 2020-х рр. У ній мали б знайти віддзеркалення минулі здобутки в організації оцінки майна, прогнози розвитку оціночної діяльності та проблеми, які не знаходять вирішення. Проєкт такої Концепції наразі створюється.

Розпочата реформа житлово-комунального господарства України в 2010-х рр. зробила актуальною нову для нашої країни професію управляючого будовами, зокрема багатоквартирними будинками. Потреба у фахівцях 3 управління нерухомістю сформувалася під впливом розширення права співвласників багатоквартирних будинків на розпорядження спільним майном. Адже мешканці багатоквартирних будинків отримали право самостійно обирати одну 3 трьох форм управління [17]. Йдеться, зокрема, про такі форми:

- створення об'єднання співвласників багатоквартирного будинку (ОСББ), що спонукає брати на себе відповідальність мешканців власного будинку;

- залучення до управління будинком управителя, якого співвласники обирають самостійно, або у разі неприйняття рішення про форму управління управителя на конкурсній основі призначає міська влада;

- самостійне управління багатоквартирним будинком, не створюючи ОСББ та не залучаючи управителя.

Надання послуги з управління багатоквартирним будинком, що здійснюється управителем на підставі договору про надання послуг 3 управління, укладається відповідно до вже згаданого Закону [17] та Закону України «Про житлово-комунальні послуги» [18]. 
У сучасному тлумаченні, компетентності підприємців, залучених до управління багатоквартирною нерухомістю, передбачають здатність виконання таких функцій:

- утримання спільного майна багатоквартирного будинку, включно з внутрішніми будинковими приміщеннями та прибудинковими територіями;

- виконання санітарно-технічних робіт;

- обслуговування внутрішніх будинкових систем;

- придбання електричної та теплової енергії для забезпечення функціонування спільного майна багатоквартирного будинку;

- поточний ремонт спільного майна багатоквартирного будинку.

Очевидно, що наведений перелік функцій охоплює лише незначну частину передусім лише технічних вимог до результатів підприємницької діяльності у цій сфері. Тому він $є$ неповним. Зокрема, ним не охоплено економічних та комунікаційних функцій, відповідно, компетентностей, що їх повинен мати управлінець. У складі останніх, на наш погляд, мали б бути зазначені такі функції:

- отимізація витрат на утримання, ремонт, модернізацію споруди з урахуванням іiї технологічного стану;

- моніторинг якості послуг та цін на послуги виконавців ремонтних, відновлювальних тощо робіт;

- укладання договорів на виконання робіт з будівельними та ремонтними організаціями і контроль за їх виконанням;

- розробка бізнес-проєктів та знаходження зовнішніх джерел фінансування для покращення стану споруди, збереження довкілля, підвищення комфортності проживання тощо;

- комунікація 3 органами місцевої та центральної влади у випадках непередбачуваних ситуацій, техногенних загроз тощо; майна тощо.

- участь в укладанні договорів зі страхування будівель, споруд,

На наш погляд, підприємницька діяльність у сфері управління спорудами характеризується надзвичайно високою невизначеністю порівняно з іншими видами діяльності на ринку нерухомості. Крім іншого, це спричиняється й відсутністю традиції ведення бізнесу у цій сфері, відповідно, браком досвіду українських підприємців у цій сфері.

У XXI ст. на ринку нерухомості України започатковано й активно розвивається новий вид підприємництва - девелоперство.

Девелоперська компанія - організація, що отримує прибуток від створення та розвитку об'єктів нерухомості, збільшуючи їх вартість. У широкому сенсі, це - юридична або фізична особа, що забезпечує просування і реалізацію бізнесового проєкту в сфері нерухомості.

У 2020 р. в Україні зареєстровано близько 400 девелоперських компаній. Експерти стверджують, що майже 90\% послуг у сфері 
девелопменту виконують вітчизняні компанії. Частка іноземних компаній $\epsilon$ незначною. Це пов'язано з тим, що українські девелоперські компанії мають певні переваги на ринку. Зокрема, ті, що пов'язані з використанням земельних ділянок, 3 кращою адаптованістю до особливих умов української економіки.

Традиційно, до функцій девелоперських компаній на ринку нерухомості належать:

- оформлення в місцевих органах влади дозвільної документації на будівництво (розпорядження щодо проєкту, інвестиційний контракт, технічний паспорт, отримання узгоджень та дозволів);

- управління проєктуванням (формування групи проєктувальників, управління підготовкою ескізного проєкту та техніко-економічного обгрунтування (ТЕO);

- управління будівництвом (проведення тендерів серед будівельних підрядників, управління будівництвом, здача об'єкта в експлуатацію);

- залучення зовнішніх кредитних та інвестиційних коштів (розробка інвестиційної стратегії проєкту, структури фінансування проєкту, договорів для підписання між компанією та фінансовими установами);

- просування об'єктів нерухомості (розробка маркетингової концепції та стратегії, розміщення реклами, розробка типового договору оренди або продажу й проведення переговорів 3 потенційними клієнтами).

Девелоперська компанія може виконувати як роль інвестора у девелоперському проєкті, так і роль посередника, а також організатора інвестиційного проєкту в сфері нерухомості.

Девелоперська діяльність $є$ особливим підприємництвом, пов'язаним з обслуговуванням інвестиційних проєктів у сфері нерухомості. Беручи на себе відповідальність за терміни та якість виконання проєкту, девелопери одночасно беруть на себе й частину проєктних ризиків. Однією з проблем підприємницької девелоперської діяльності в Україні $є$ необгрунтоване перекладання цих ризиків девелоперами на інших економічних суб'єктів та намагання уникнути відповідальності.

До інфраструктури ринку нерухомості, як ілюстровано на рис. 3, належать ті підприємства й організації, які не формують власне ринок нерухомості, але створюють зовнішне середовище його функціонування. Це зовнішнє середовище формується за участі: національних регуляторів ринку нерухомості, фінансово-кредитних установ (зокрема, банків іпотечного кредитування), будівельних підприємств, консалтингових підприємств, страхових компаній.

Національні регулятори ринку нерухомості - це передусім органи державної влади у складі: Міністерства фінансів України (зокрема, в частині фінансового моніторингу), Фонду державного майна України, Міністерства розвитку громад та територій України. Спеціального дослідження потребує питання приналежності до національних регуляторів 
загальноукраїнських професійних асоціацій (об’єднань). До таких, зокрема, належать уже згадувані нами громадські організації в особі Асоціації фахівців з нерухомості (рієлторів) України (АФНУ); Спілки фахівців 3 нерухомого майна України (СФНУ); Українського товариства оцінювачів (УТО), Конфедерації будівельників України (КБУ), Будівельної палати України.

Фінансово-кредитні організації в особі банків іпотечного кредитування та інших комерційних банків $є$ причетними до функціонування ринку нерухомості. Адже вони надають фінансові ресурси, яких тимчасово бракує учасникам ринку. Активно займаються іпотечним кредитуванням такі українські банки, як ПАТ «Кредобанк», Укргазбанк, Правекс-банк, Ощадбанк, Приватбанк.

Іпотечне кредитування в Україні намагаються відродити за рахунок зниження відсоткової ставки за користування кредитними коштами. При цьому змінилися вимоги до позичальників, а саме до підтвердженого офіційного доходу позичальника. Банки більш ретельно перевіряють інформацію про доходи. Найбільшою проблемою кредитування є недовіра позичальників саме до іпотечного кредитування. Вона спричинена негативним досвідом позичальників періоду «іпотечного буму» $2006-2008$ pp.

Будівельні підприємства створюють ту частину зовнішнього середовища ринку нерухомості, яка пов'язана 3 виникненням нових об'єктів цього ринку та їх відтворенням у належному стані (ремонтуванням). Існують певні особливості взаємин безпосередніх учасників ринку з будівельними організаціями. Загалом, ці взаємини $\epsilon$ конструктивними. Співпраця між фахівцями ринку нерухомості й забудовниками активно розвивається. Співпраця здійснюється здебільшого у таких формах:

- забудовники, маючи угоду з певним агентством нерухомості, сплачують йому комісію за просування та продаж об’єктів нерухомого майна покупцеві;

- забудовники співпрацюють з усіма рієлторами, які рекомендують та продають об'єкти, створені забудовником, на засадах так званої публічної оферти співпраці для всіх рієлторів.

Проблема співпраці забудовників з агентами ринку нерухомості пов'язана передусім з тим, що деякі забудовники ідентифікують рієлторів як конкурентів. Ідеться про конкуренцію та нібито «конфлікт інтересів» відділів продажів забудовника і рієлторів. Таке тлумачення «конфлікту інтересів» $€$ хибним хоча б тому, що у відділу продажів $\epsilon$ функція реклами об'єкту. Останньої не має рієлтор, який забезпечує комплексний супровід руху об'єкту нерухомості від забудовника до покупця.

Ще один сегмент інфраструктури ринку нерухомості консалтингові підприємства - можуть бути причетними до створення 
проєктів оновлення будівель та споруд, до їх перепрофілювання, до використання інноваційних технологій, до пошуку інвесторів у країні та за їі межами.

Страхові компанії $є$ компонентом інфраструктури будь-якої підприємницької діяльності, включно з діяльністю на ринку нерухомості. В українських умовах роль страхових компаній мала б бути більш масштабною та краще регламентованою. Це пояснюється значною амортизацією нерухомості, техногенними загрозами, пов'язаними 3 незадовільним станом комунального господарства, з браком необхідних стандартів у будівництві та обслуговуванні споруд.

На ринку нерухомості існує декілька видів страхування. Найбільш поширеними $є$ класичне страхування об'єкту нерухомості як майна та страхування прав на нерухомість - так зване титульне страхування. Більш поширеним в Україні є перший вид страхування. Розвиток послуг страхування нерухомості стримується насамперед алгоритмом ціноутворення. Ціна страхової послуги визначається як певний відсоток від вартості об'єкту, що сплачується щорічно. По-друге, існує дуже складна процедура отримання страхового відшкодування при настанні страхового випадку, що розширює межі економічної невизначеності.

\section{Висновки:}

3 аналізу інфраструктури ринку нерухомості України та підприємництва, пов'язаного з цим ринком, робимо такі узагальнення.

Український ринок нерухомості має значний потенціал розвитку та позитивного впливу на стабілізацію всієї національної економіки. Ринок створює сотні тисяч робочих місць і формує помітну частину доданої вартості, репрезентованої у ВВП країни.

Стабілізаційний потенціал українського ринку нерухомості реалізується неповно. Це стосується всіх складників ринку та усіх видів підприємницької діяльності, що формують передусім «ядро» інфраструктури ринку. Йдеться про такі види підприємництва, як рієлторство, оціночна діяльність, управління нерухомістю, девелоперство.

Кожний вид підприємництва на ринку нерухомості має особливі проблеми діяльності, здатні посилювати економічну невизначеність. Але $є$ принаймні дві загальні для всіх сегментів ринку проблеми. Периа пов'язана 3 незавершеністю й недосконалістю законодавчої бази щодо діяльності фахівців ринку та їх взаємин 3 органами державної влади. Друга стосується професійної самоорганізації ринку, здійснюваної громадськими самоврядними професійними організаціями.

Українські громадські професійні самоврядні організації покликані сприяти вирішенню низки першочергових проблем функціонування ринку нерухомості, а саме:

- створенню та лобіюванню необхідної для стабілізації ринку нерухомості нормативної бази; 
- ідентифікації професійних стандартів діяльності на ринку та контролю за їх дотриманням;

- сприяння формуванню системи професійної освіти та системи перекваліфікації фахівців ринку нерухомості;

- налагодженню ефективної комунікації між органами державної влади (національними регуляторами) з підприємцями, з одного боку, та між підприємцями та споживачами послуг - 3 іншого.

\section{Лimepamypa:}

1. Статистичний щорічник України. URL : http://www.ukrstat. gov.ua/druk/publicat/kat_u/2019/zb/11/zb_yearbook_2018.pdf.

2. Amadeo K. Is the Real Estate Market Going to Crash? URL : https://www.thebalance.com/is-the-real-estate-market-going-to-crash-4153139.

3. Real Estate in a Digital Age 2019 Report. URL : https://www.nar. realtor/research-and-statistics/research-reports/real-estate-in-a-digital-age.

4. Lawrence Y. Housing Demand over the Next Decade. National association of realtors. The Economists' Outlook Blog. 2017. URL : http://economistsoutlook.blogs.realtor.org/2017/03/02/housing-demandover-the-next-decade/.

5. Возняк Г. В. Сучасні механізми фінансування будівництва житла в Україні: проблеми та шляхи вирішення. Бізнес Інформ. 2019. №8. C. 111-116. URL : https://doi.org/10.32983/2222-4459-2019-8-111-116.

6. Кривов'язюк I. В., Свчук А. В. Тенденції розвитку інвестиційно привабливих ринків нерухомості країн Свропи. URL : http://www.vestnikeconom.mgu.od.ua/journal/2019/35-2019/5.pdf.

7. Галаган Д. В. Ринок нерухомості як різновид інвестиційного ринку. URL : http://irbis-nbuv.gov.ua/cgibin/irbis64r_81/cgiirbis_64.exe?C $21 \mathrm{COM}=2 \& \mathrm{I} 21 \mathrm{DBN}=\mathrm{UJRN} \& \mathrm{P} 21 \mathrm{DBN}=\mathrm{UJRN} \& Z 21 \mathrm{ID}=\& \mathrm{IMAGE}$ FILE_ DOWNLOAD=1\&Image_file_name=PDF/ipd_2010_9_7pdf.

8. 5 Indicators To Watch In The Housing Market Recovery From The Coronavirus. URL : https://www.forbes.com/sites/dimawilliams/2020/ 05/15/five-indicators-to-watch-in-the-housing-market-recovery-from-thecoronavirus/-247420145f06.

9. Національний класифікатор України, класифікація видів економічної діяльності. Державний комітет України з питань технічного регулювання та споживчої політики. URL : https://zakon.rada.gov.ua/ rada/show/vb457609-10\#Text.

10. Про рієлторську діяльність в Україні : Проєкт Закону України від 09.09.2020 p. №3618. URL : http://w1.c1.rada.gov.ua/pls/ zweb2/webproc4_1?pf3511=69071.

11. Топал А. Ремісництво - загроза фаху: матеріали Національного форуму «Нерухомість України». Київ, 6-7 груд. 2012 р. 
12. Громадська організація «Асоціація професійних управляючих нерухомістю». URL : https://apun-ua.est.ua/info/.

13. Міненко М. А. Ріелторство в Україні. Державне управління: удосконалення та розвиток. №4. 2013. URL : http://www.dy.nayka.com.ua/ ?op $=1 \& \mathrm{z}=566$.

14. Про прийняття національного стандарту ДСТЕУ ЕN 15733:2019 «Послуги агентів 3 нерухомості. Вимоги до надання послуг агентів 3 нерухомості : Наказ ДП «УкрНДНЦ» Національного органу стандартизації №40 від 27 лютого 2019 p. URL : http://uas.org.ua/wp-content/uploads/ 2019/03/N40_2019-02-27.rtf.

15. Міненко М. А. Ріелторство в Україні. Державне управління: удосконалення та розвиток. №4. 2013. URL : http://www.dy.nayka.com.ua/ ?op $=1 \& \mathrm{z}=566$.

16. Про оцінку майна, майнових прав та професійну оціночну діяльність в Україні : Закон України від 12.07.2001 р. №2658-III. URL : https://zakon.rada.gov.ua/laws/show/2658-14\#Text.

17. Про особливості здійснення права власності у багатоквартирному будинку : Закон України редакція від 10.06.2018 р. №2189-VIII. URL : https://zakon.rada.gov.ua/laws/show/417-19.

18. Про житлово-комунальні послуги : Закон України від 09.11.2017 p. №2189-VIII. URL : https://zakon.rada.gov.ua/laws/show/ 2189-19\#Text. 
Вищий навчальний заклад «Університет економіки та права «КРОК»

Колективна монографія

\section{Економіка невизначеності: зміст, оцінювання, регулювання}

Оригінал-макет підготувала Н. О. Ткаченко

Підписано до друку «17» січня 2021 р.

Формат 60×84/16. Папір офсетний.

Гарнітура Times New Roman.

Друк різографічний. Ум. друк. арк. 15,64.

Наклад 300 прим. Замовлення №219. 